Florida International University FIU Digital Commons

\title{
Process inventory and pollution prevention overview for the citrus industry
}

Carmen Alicia Aponte

Florida International University

DOI: $10.25148 /$ etd.FI14032327

Follow this and additional works at: https://digitalcommons.fiu.edu/etd

Part of the Environmental Engineering Commons

\section{Recommended Citation}

Aponte, Carmen Alicia, "Process inventory and pollution prevention overview for the citrus industry" (2000). FIU Electronic Theses and Dissertations. 1298.

https://digitalcommons.fiu.edu/etd/1298 
Miami, Florida

\title{
PROCESS INVENTORY AND POLLUTION PREVENTION OVERVIEW FOR THE CITRUS INDUSTRY
}

A thesis submitted in partial fulfillment of the

\author{
requirements for the degree of \\ MASTER OF SCIENCE \\ IN \\ ENVIRONMENTAL ENGINEERING \\ by
}

Carmen Alicia Aponte 
To: Dean Gordon R. Hopkins

College of Engineering

This thesis, written by Carmen Alicia Aponte, and entitled Process Inventory and Pollution Prevention Overview for the Citrus Industry, having been approved in respect to style and intellectual content, is referred to you for judgment.

We have read this thesis and recommend that it be approved.

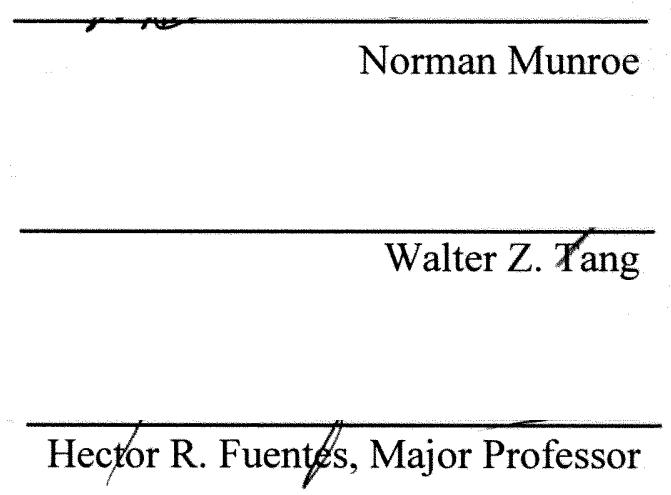

Date of Defense: March 15, 2000

The thesis of Carmen Alicia Aponte is approved.

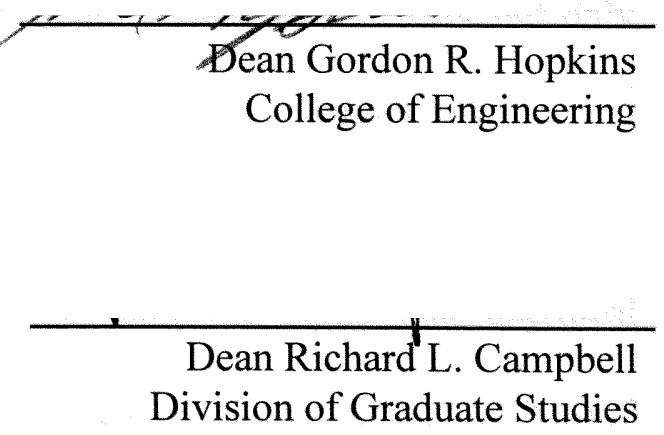

Florida International University, 2000 
OF

PROCESS INVENTORY AND POLLUTION PREVENTION OVERVIEW FOR THE CITRUS INDUSTRY

\author{
by \\ Carmen Alicia Aponte \\ Florida International University, 2000 \\ Miami, Florida \\ Professor Hector R. Fuentes, Major Professor
}

Florida citrus represents approximately 70 percent of the industry production in the United States; therefore, any associated agricultural and industrial contamination is of concern and a focus of attention. The use of synthetic organic chemicals has become a farmer's necessity in order to supply consumers with high quality products, free of pest damage. However, industrial citrus wastes and chemical residual levels worry not only government agencies but also consumers since they indicate a serious habitat risk.

This study assesses citrus industrial processes and the paths that chemical substances follow from the time the citrus seed is planted until consumers get a final product as either fresh fruit or processed product. The study is built on information from United States Environmental Protection Agency (US EPA) manuals, Dade County 
Environmental Resources Management (DERM) inspection records, United States Food and Drug Administration (US FDA) regulations, Florida standards, journal publications, and research reports. Pollution prevention (P2 or prevention-of-pollution) alternatives are identified; alternatives are proposed, evaluated, and included. Strategies are described and pollution prevention opportunities proposed to minimize citrus wastes generation, chemical residuals in products, their environmental impact and health risk aspects while maximizing product quality.

Keywords: Citrus, Industry, Contamination, Wastewater, Solid Waste, Pollution Prevention/P2/Prevention-of-Pollution, and Florida. 


\section{DEDICATION}

Dedicated to my family, which provided me with emotional support throughout this long period of time called graduate school. To my Major Professor Dr. Hector R. Fuentes and

friends: Martha Arboleda, Jumel Pluviose, Lucero and Blanca Vaca, and Sangeeta Dhulashia for their encouragement and trust. 


\section{ACKNOWLEDGMENTS}

I would like to thank Dr. Hector R. Fuentes, director of the thesis and Major Professor, for his continued support, guidance, encouragement, and trust. His firm direction is most appreciated. This thesis is a result of a grant provided by the United States Environmental Protection Agency (USEPA) through my Major Professor Dr. Hector R. Fuentes. The author also wishes to acknowledge Dr. Walter Z. Tang and Dr. Norman Munroe who guided me with their comments and thesis review toward my graduate goals. Special acknowledgment to Victor Young's memory, for giving me the opportunity to work with him at the Waste Reduction Resource Center (WRRC) in Raleigh, North Carolina during my internship. Acknowledgment is also due to Bob Carter, Rudy Moehrbach, John Dawkins, and Jim Grovenstein for their support in the WRRC. 
$1.1 \quad$ Pollutant Facts........................................................

1.2 Synthetic Organic Compounds in Foods.............................15

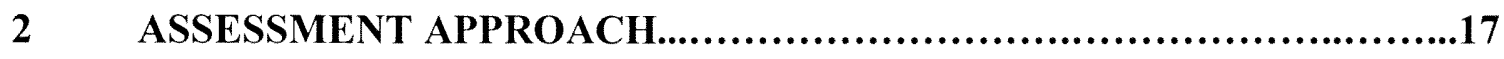

$2.1 \quad$ Pollution Prevention (P2) Assessment.............................17

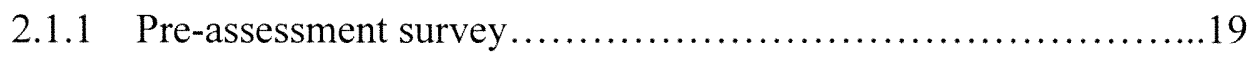

2.1.2 Waste characterization..................................19

2.1.3 Pollutant quantification................................20

2.1.4 Mass balances..........................................20

2.1.5 Implementation phase: pollution prevention program............21

2.1.6 Evaluation of pollution prevention program..................21

2.1.7 Cost evaluation..........................................21

2.1.8 Payback period..........................................22

2.1 .9 Results................................................ 22

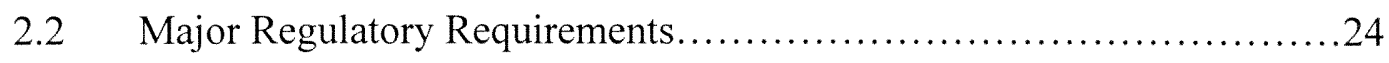

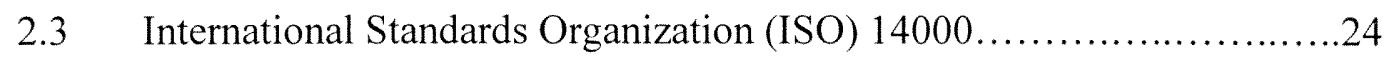

2.3.1 Environmental Management Systems (EMS ..................25 
2.3.2 Environmental Auditing ..................................26

2.3.3 Environmental Performance Evaluation (EPE) .................26

2.3.4 Environmental Aspects in Product Standards (EAPS) ..........27

2.3.4.1 Life Cycle Assessment (LCA) .......................27

2.3.4.2 Environmental labeling.............................28

3 LITERATURE REVIEW .................................................

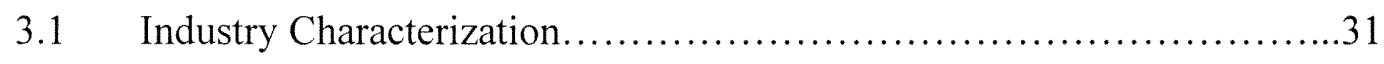

$3.2 \quad$ Unit Operations Diagram.............................................. 36

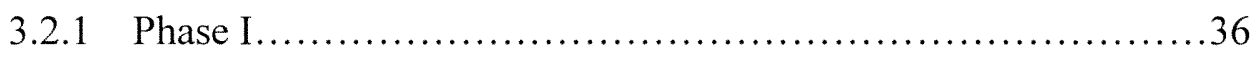

3.2.1.1 Pre-harvesting..........................................36

3.2.1.2 Agriculture and prevention-of-pollution aspects...........55

3.2.1.3 Irrigation........................................61

3.2.1.4 Behavior of pesticides in soil, water, and air..............63

3.2.2 Phase II...............................................69

3.2.2.1 Harvesting.............................................69

3.2.2.2 Detaching fruit, handling, and collection.................72

3.2.3 Phase III.............................................. 73

3.2.3.1 Transport......................................... 73

3.2.4 Phase IV - XIV ............................................ 73

3.2.4.1 Canning plants.................................. 73 
3.3 Industry Contamination.

3.3.1 Pesticides and Other Substances............................93

3.3.1.1 Intentional.........................................93

3.3.1.2 Unintentional.......................................99

3.3.1.3 Tolerances for pesticides residues......................94

3.4 Assessment Sources and Environmental Significance.....................96

3.5 Citrus Industry Listing............................................... 98

3.6 Cost Feasibility ............................................... 105

5.1 Method. 108

6 RESULTS AND DISCUSSION

6.1 Pollution Assessment.

6.1.1 Phase I: Pre-harvesting.

6.1.2 Phase II: Harvesting (canning and packinghouses).

6.1.3 Phase III: Transport (canning and packinghouses)

6.1.4 Phase IV: Pre-selection (canning and packinghouses) 
6.1.5 Phase V: Brushing and Quality Sorting (canning plant) 113

6.1.6 Phase VI: Brushing and Quality Sorting (packinghouses).......113

6.1.7 Phase VII: Rinsing (canning and packinghouses).............114

6.1.8 Phase VIII: Sorting and Grading (canning and packinghouses)..114

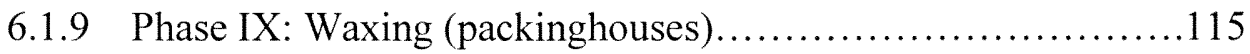

6.1.10 Phase X: Drying (packinghouses) ..........................115

6.1.11 Phase XI: Quality Sorting (packinghouses) $\ldots \ldots \ldots \ldots \ldots \ldots \ldots 116$

6.1.12 Phase XII: Packaging and Related Activities (packinghouses)...116

6.1.13 Phase XIII: Juice Production and Byproducts (canning plant)...117

6.1.14 Phase XIV: Citrus Byproducts (canning plant)................117

6.1.15 Phase XV: Markets (canning and packinghouses)..............119

6.2 Contamination Frame............................................... 119

6.2.1 Agriculture Activities.................................. 120

6.2.1.1 Water, soil, air, and living organisms compartment.......120

6.2.1.1.1 Herbicides, insecticides, and nematicides......120

6.2.2 Effluent and Emissions................................... 120

6.2.2.1 Wastewater stream.................................. 123

6.2.2.2 Solid waste stream.................................131

6.2.2.3 Citrus, chemical residuals, and health risk................134

6.2.2.4 Life Cycle Assessment..............................136

6.2.2.5 A preliminary gap analysis..........................139 
7.1 Agriculture, Harvesting, and Management Practices.

7.2 Production Operations.....

7.2.1 Wastewater stream.

7.2.2 Solid waste stream.

7.2.3 Transportation and distribution.

7.2.4 Use, reuse, and recycle. 156

7.2.5 Waste management. 160

7.2.5.1 Management considerations.... 160

7.2.5.2 Raw fruit considerations. 161

7.2.5.3 Processed fruit needs. 162

7.2.5.4 Cleanup considerations. 163 
CHAPTER

PAGE

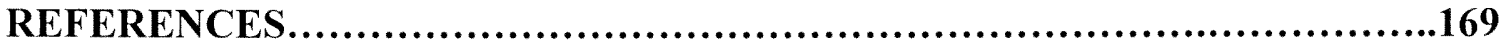

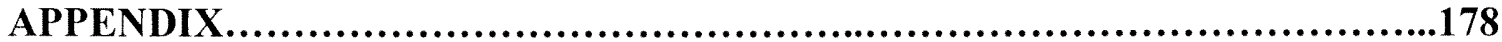




\section{LIST OF TABLES}

TABLE

PAGE

Table 1. Approximate Citrus Net Weight in Pounds per Box...........................5

Table 2. Approximate Citrus Production by State................................. 5

Table 3. Florida Citrus Production by County 1997-1998_...........................6

Table 4. Effluent Limitation Guidelines (Wastewater Discharges) ..................... 10

Table 5. Disposal Sites and Volumes of Food Processing Wastewater Including

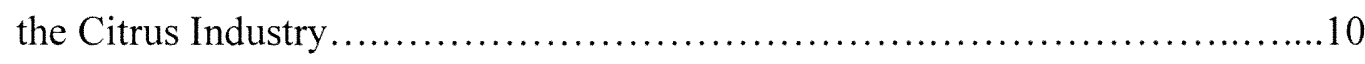

Table 6. Wastewater and Pollutant Load from Fresh Citrus Operations..................11

Table 7. Water Used, Wastewater, and Pollution Loads Generation ....................11

Table 8. Pesticide Considered by the Court of Appeals Ruling........................16

Table 9. Pollution Prevention Regulatory Requirement.............................23

Table 10. The ISO 14000 Series................................................. 30

Table 11. General Data on the Citrus Activity ......................................32

Table 12. Mineral Nutrition in the Production of Citrus Fruit...........................44

Table 13. Impact of Excess of Fertilizers in the Environment...........................46

Table 14. Herbicides and Mode of Action..........................................46

Table 15. Relative Persistence of Herbicides in Soils..................................49

Table 16. Herbicides Registered for Use on Florida Citrus..........................51

Table 17. Insecticides Most Used in Citrus and Agrochemical Properties................53

Table 18. Agrochemical Properties of Most Common Acaricides in Citrus..............53 
Table 19. Fungicides Registered for Use in Florida Citrus Crops.......................54

Table 20. Restricted Pesticides Registered for Use on Florida Citrus...................56

Table 21. Non-restricted Pesticides for Use on Florida Citrus..........................59

Table 22. Adsorption Coefficient for Selected Pesticides Used in Florida

Citrus Groves

.64

Table 23. Disinfectants Used in the Citrus Industry................................89

Table 24. Fresh Fruit Cleaners................................................. 90

Table 25. Citrosol Fungicides and Waxes Used in the Citrus Industry..................91

Table 26. Donovan Brown Fungicides and Waxes Used in the Citrus

Industry

Table 27. Estimated Oncongenic Risk Distribution by Pesticide Type on Fresh and

Processed Fruit

Table 28. Greatest Estimated Oncongenic Risk from Fungicides on Oranges .95

Table 29. Citrus Companies Licensed and Registered 1998-1999 Season....

Table 30. Herbicides, Properties Environmental Impact.

Table 31. Insecticides, Properties, and Environmental Impact

Table 32. Nematicides, Properties, and Environmental Impact.

Table 33. Total Wastewater Generated During 1997-1998 Season

Table 34. Dade County Department of Environmental Resources Management (DERM). Inspection Reports to Golden Corporation 
Table 35. Dade County Department of Environmental Resources Management (DERM). Inspection Reports to Fruits and Farms. 127

Table 36. Citrus Industry Solid Residual in a Seasonal Year 132

Table 37. Waste Generated During $1997-1998$ by the Citrus Industry..... 132

Table 38. Environmental Gap Analysis and Ranking Scale of the Citrus Industry......140 Table 39. Prevention-of-pollution Cost Evaluation Worksheet for the Citrus Industry..147 Table 40. Technologies and Best Management Practices to Mitigate Contamination...149

Table 41. Alternatives for Efficient Water Use................................... 152

Table 42. Alternatives to Handle Solid Waste........................................ 155

Table 43. Water Economy Checklist for the Citrus Industry ........................158 


\section{LIST OF FIGURES}

FIGURE

PAGE

Figure 1. The United States and Citrus Production Areas............................... 4

Figure 2. Comparative Citrus Production for the United States and Florida.............. 7

Figure 3. Relationship between Pesticides, Nature, and Society.........................13

Figure 4. Pollution Prevention Assessment Diagram.................................. 18

Figure 5. Fresh Orange Production in the World 1996-1998...........................32

Figure 6. Fresh Grapefruit Production in the World 1996-1998_.....................33

Figure 7. Fresh Lemon Production in the World 1996-1998............................34

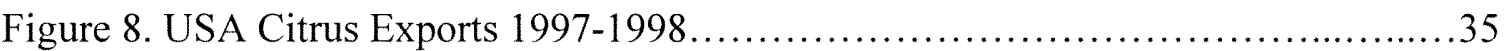

Figure 9. Florida Fresh Citrus Exports Contribution 1996-1998_......................37

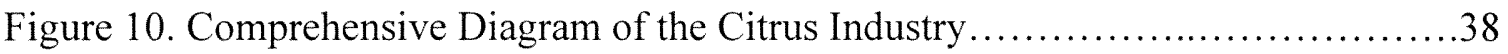

Figure 11. Mass Balance/Fresh Fruit Product........................................124

Figure 12. Mass Balance/Concentrated Product................................. 125

Figure 13. Mass Balance/Juice Product...........................................125

Figure 14. Inputs and Outputs in the Packinghouse of Fruits and Farms

in Miami, Florida................................................. 128

Figure 15. Mass Balance/Limes Packaging in Golden Corporation.....................130

Figure 16. Mass Balance/Total Solid Waste....................................... 133

Figure 17. Suggested Life Cycle Assessment Inventory for the Citrus Industry........138 


\section{LIST OF PHOTOGRAPHS}

\section{PHOTOGRAPH}

PAGE

Photograph 1. Manual Fruit Harvesting ........................................ 70

Photograph 2. Dumping Citrus Bag into a Tub.................................. 70

Photograph 3. Mechanical Fruit Harvesting ...................................... 71

Photograph 4. Tub Full of Oranges........................................... 74

Photograph 5. Goat Picking-up the Tub........................................ 74

Photograph 6. Goat Loaded with Fruit............................................ 75

Photograph 7. Goat Dumping Fruit into a Trailer.................................. 75

Photograph 8. Trailers at a Processing Plant..................................... 77

Photograph 9. Fruit Unloading ................................................ 77

Photograph 10. Fruit Storage Bins.............................................. 78

Photograph 11. Washing Process................................................ 79

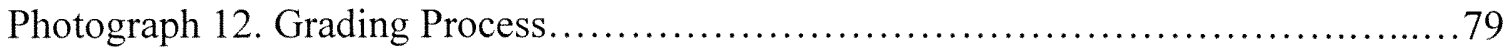

Photograph 13. Juice Extraction................................................ 81

Photograph 14. Screening (Filtering seeds and pulp from juice) $\ldots \ldots \ldots \ldots \ldots \ldots \ldots \ldots \ldots 1$

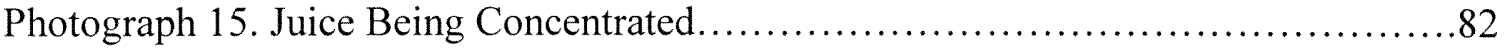

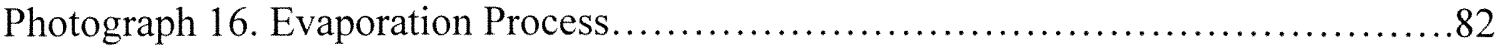

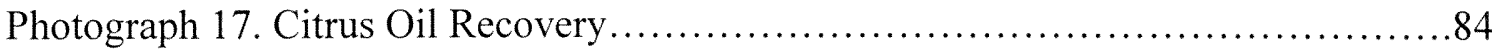

Photograph 18. Peel and Pulp Drying for Cattle Feed............................... 84 


\section{PROCESS INVENTORY AND POLLUTION PREVENTION OVERVIEW \\ FOR THE CITRUS INDUSTRY}

\section{INTRODUCTION}

Florida, named as the nation's eighth leading agricultural state, remains in first place in the southeast for orange production. Florida's major agricultural county citrus leaders are: Polk with orange production, Dade with lime production, and Indian River with grapefruit production. Florida's citrus industry is recognized as one of the main producers in the United States of America (USA), not only of fresh fruit but also of processed product. The economical potential pollution prevention ( $\mathrm{P} 2$ or prevention-ofpollution) for this industry is critical for farmers and industrialists, so that they can competitively continue offering high quality products. These products also should meet cosmetic standards required by the United States Food and Drug Administration (USFDA), the United States Department of Agriculture (USDA), the United States Environmental Protection Agency (USEPA), and consumers.

The Florida citrus industry contributes to environmental contamination, since citrus wastes reach important natural resources such as soil, air, surface water, ground water, animals, and humans. Control of environmental contamination requires a full understanding of the chemical and biological processes involved in both agricultural activities and industrial processes. Careful consideration and adequate precaution should 
be taken in farming, harvesting, and processing citrus, either fresh fruit or byproducts, to minimize environmental impacts, such as leaching, accumulation of toxic levels on the soil, air pollution, and human and animal health risks.

Sponsored by the United States Environmental Protection Agency (USEPA), the Department of Civil and Environmental Engineering of Florida International University (FIU) conducted this study to assess prevention-of-pollution opportunities of the citrus industry. The study investigated the pollutant situation in Florida citrus crops and industries, identifying opportunities and recommending prevention-of-pollution alternatives within the context of federal, state, and local regulations. The goal was to avoid, eliminating if feasible, and reduce contaminant residues in the environment.

\section{$1.1 \quad$ Pollutant Facts}

The citrus industry is complex with varied activities from farming to production, each generating contamination. Even though, the USEPA and other government agencies have been joining efforts to control and reduce the use of chemical compounds and other wastes in agriculture activities, many opportunities exist to reduce pollution in farming, processing citrus, and related activities with beneficial health, environmental, and economic consequences (USEPA, 1992a). Banning the use of environmentally persistent chemicals plays an important role in promoting and developing prevention-of-pollution programs. This role is crucial because it helps reduce health and environmental risks. The 
most important objectives related to prevention-of-pollution for any industry-and obviously, for this case of study, the citrus industry - are to prevent, reduce, and recycle wastes before they become pollutants (Linker et al., 1988).

After 1940, the citrus industry in Florida, California, Texas, and Arizona unexpectedly grew due to new technologies (see Figure 1). The Florida State Statistical Report reported approximately 304,330,000 boxes of citrus production during 1998-1999 as fresh product. Each box is classified by weight, type of fruit, and state (see Tables 1 and 2) (USDA 1998a). During 1997-1998 foreign exports in Florida accounted for approximately 30 million 4/5-bushel cartons of fresh fruit. Canada is the main consumer of Florida oranges, specialty fruit, and approximately 23 million gallons of frozen concentrate orange juice (FCOJ). Japan demands large quantities of grapefruit and frozen concentrate grapefruit juice (FCGJ) in approximately 8.4 million gallons (USDA 1998a).

The Florida Agricultural Statistics Service reported the latest citrus tree census, January 1998 to January 1999; Florida citrus productivity was estimated and classified by county as shown in Table 3 . Florida represents $75 \%$ of the citrus production in the United States as shown in Figure 2. Figure 2 shows a comparative scheme, which relates principal citrus production in the United States versus Florida production as a main producer in the country. The accelerated expansion of this industry brought environmental problems, including generation of approximately $40 \%$ of pesticides residuals due to agricultural activities and large amounts of solid waste (Long, 1993). 


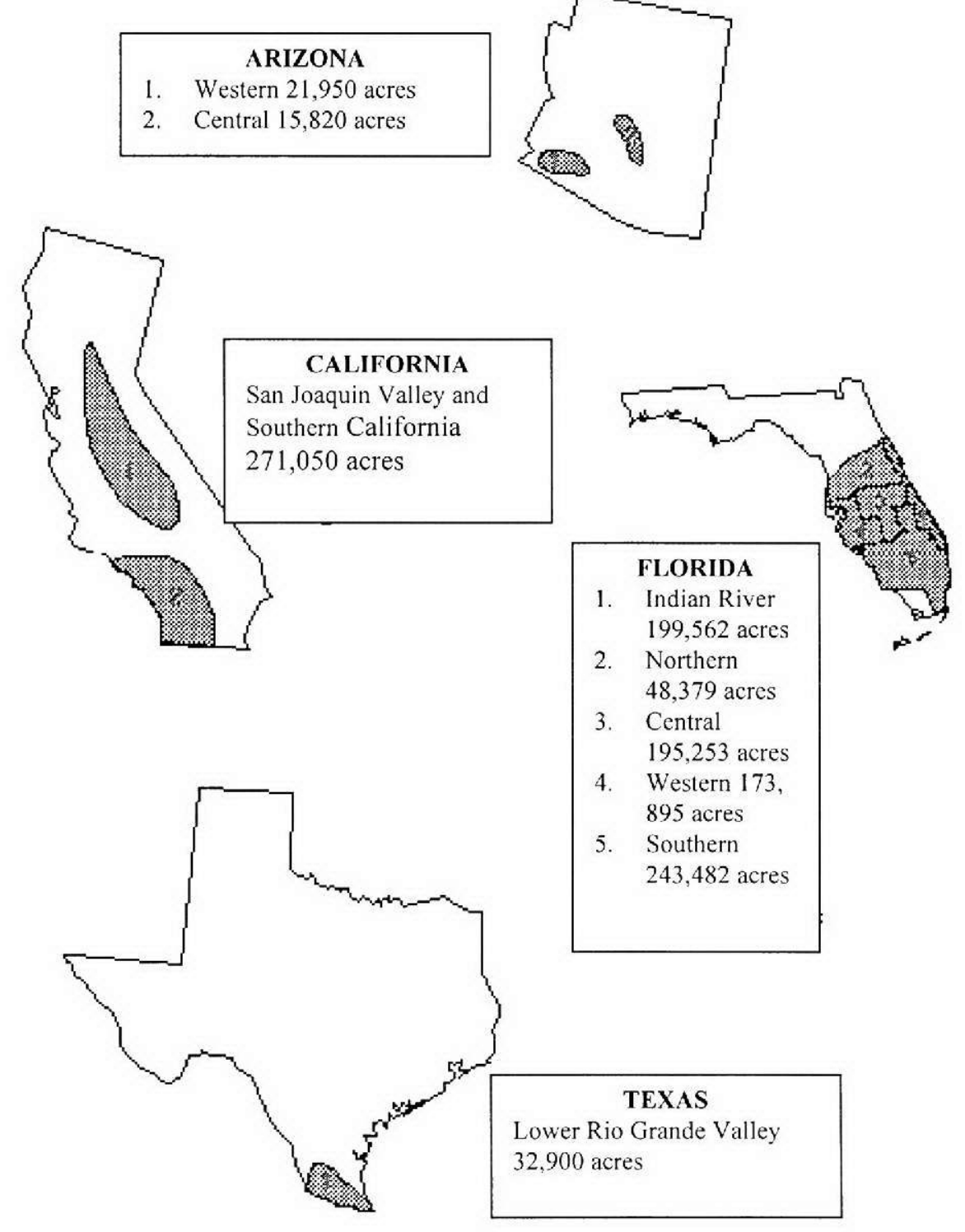

Figure 1. The United States and Citrus Production Areas (USDA, 1998b). 
Table 1. Approximate Citrus Net Weight in Pounds per Box (Source: USDA, 1998c).

\begin{tabular}{|l|l|l|l|l|l|}
\hline STATE & ORANGES & GRAPEFRUIT & TANGERINES & LEMONS & LIMES \\
\hline FL & 90 & 85 & 95 & 90 & 88 \\
\hline CA & 75 & 67 & 75 & 76 & N/P \\
\hline TX & 85 & 80 & N/P & N/P & N/P \\
\hline AZ & 75 & 67 & 75 & 76 & N/P \\
\hline
\end{tabular}

NOTE: N/P $=$ Not Produced

Table 2. Approximate Citrus Production by State

(USDA, 1998c).

\begin{tabular}{|c|c|}
\hline State & $\begin{array}{c}\text { Citrus } \\
\text { (Thousand of tons) }\end{array}$ \\
\hline FL & 18,029 \\
\hline CA & 4,003 \\
\hline TX & 257 \\
\hline AZ & 185 \\
\hline
\end{tabular}

1) Season 1997-1998

2) Thousand of tons were estimated based on an average of $90 \mathrm{lb}$. per box. 
Table 3. Florida Citrus Production by County (1997-1998)

(Florida Agricultural Statistics Service, 1999).

\begin{tabular}{|l|l|}
\hline \multicolumn{1}{|c|}{ County } & Thousand Boxes \\
\hline Polk & 40,350 \\
Hendry & 31,633 \\
St. Lucie & 31,646 \\
Highlands & 31,605 \\
DeSoto & 29,877 \\
Hardee & 23,681 \\
Indian River & 20,437 \\
Martin & 14,271 \\
Hillsborough & 11,935 \\
Collier & 11,313 \\
Manatee & 9,961 \\
Lake & 7,097 \\
Osceola & 6,933 \\
Charlotte & 5,633 \\
Pasco & 4,921 \\
Lee & 3,709 \\
Palm Beach & 3,595 \\
Okeechobee & 3,469 \\
Orange & 3,407 \\
Glades & 3,203 \\
Brevard & 2,490 \\
Sarasota & 912 \\
Dade & 440 \\
Hernando & 431 \\
Seminole & 430 \\
Volusia & 408 \\
Marion & 343 \\
Others 1/ & 200 \\
\hline
\end{tabular}

Note: 1/ Broward, Citrus, Flagler, Marion, Pinellas, Putnam and Sumter counties. 


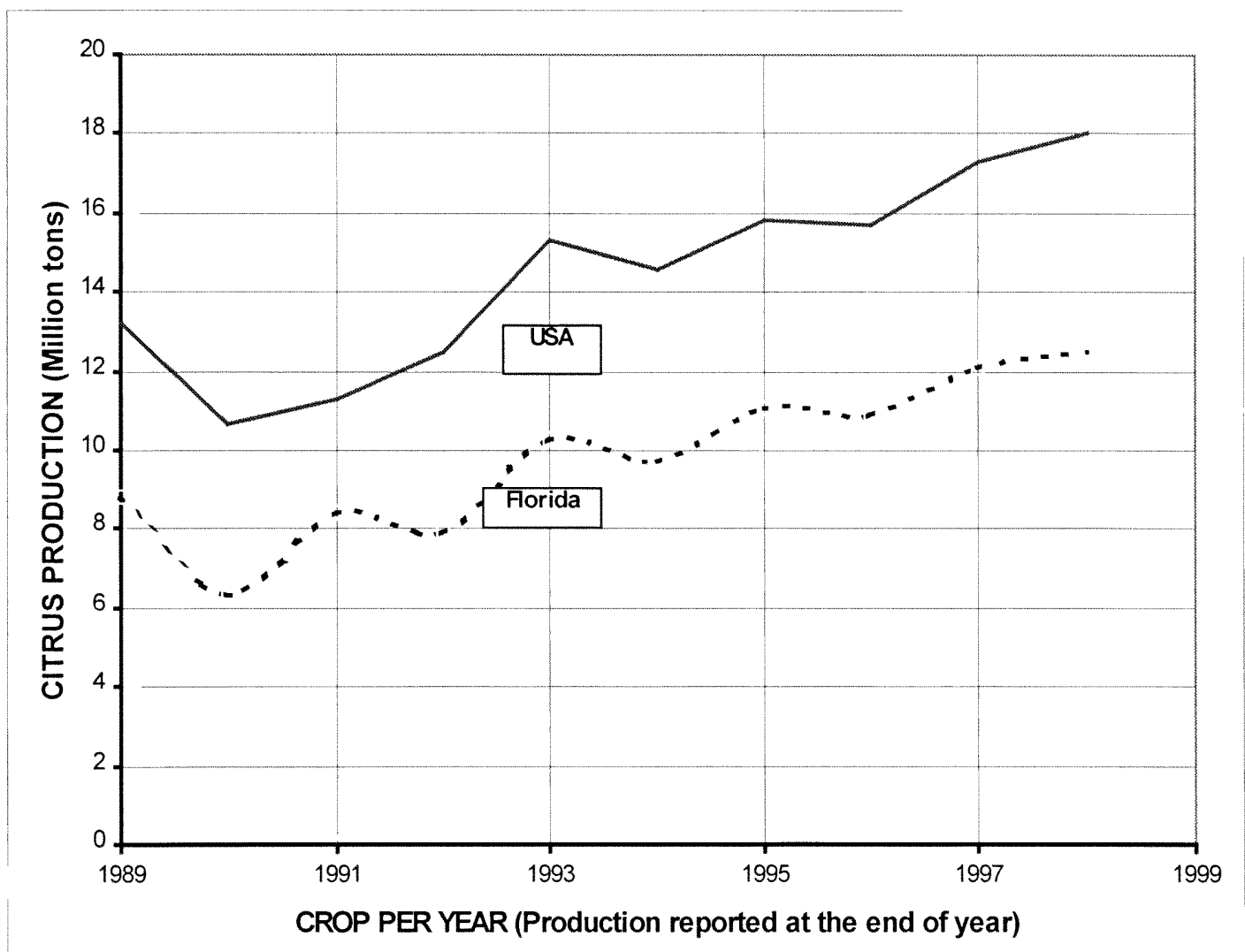

Figure 2. Comparative Citrus Production for the United States and Florida (Adapted from Florida State Statistical Report, 1999). 
Citrus waste is generally hard to typify since it depends on variables such as type of chemicals applied during harvesting, the length of the harvest season, process shifts (e.g., cleanup and processing), daily or seasonal shutdown and startup, etc. The latter variables, for instance, cause variations in citrus wastewater characteristics (Long, 1993).

Soil, water, and air contamination and solid waste generation are considered in this study. Citrus trees can grow in different types of soils, but they need special climate and rain conditions to reach maximum productivity. In Florida, the soil is mostly sandy, highly permeable, with low capacity to filter chemical substances and water. These soil characteristics makes leaching a serious problem, resulting in high risk of contamination due to chemical mobilization into surface and subsurface waters (USEPA, 1978).

Water pollution includes generation of wastewater during washing activities and releases of chemicals during agricultural activities. The Federal Water Pollution Control Act Amendments (FWPCAA) and the USEPA standards on wastewater discharges have regulated the citrus industry since 1972 (USEPA, 1975; CFR, 1999).

The effluent limitation guidelines for citrus industries is given by EPA, state, and local regulations. Processors have to pre-treat wastewater prior to discharging it to municipal sewage collectors. Local requirements may also be imposed on this industry, such as specific limits on heavy metals, toxic compounds, oil and grease, temperature, pH, etc., to prevent environmental impacts. Table 4 shows the EPA and Code of Federal 
Regulations (CFR) limits that citrus industries must meet as of 1983 and 1995 (USEPA, 1975; CFR, 1999).

Generated wastewater and disposal sites in food processing plants are illustrated in Table 5. Table 6 outlines waste from unit operations in the citrus industry. The major aspect of concern in this subject is concentrations of toxic compounds generated during citrus processing and discharged to waters. The Federal Water Pollution Control Act, Section 502 (13), defines a list of toxic pollutants that:

“... after discharge and upon exposure, ingestion, inhalation or assimilation into any organism, either directly from the environment or indirectly by ingestion though food chains, will ... cause death, disease, behavioral abnormalities, cancer, genetic mutations, physiological malfunctions or physical deformations, in such organisms or their offspring."

Quantitative data regarding water use, wastewater generated, reuse water, and discharge water in the citrus industry during 1996-1997 season is included in Table 7, where statistical data are reported according to the National Canners Association (1974). Generally, the largest volumes of wastewater are from raw product cleaning, including hydraulic transport, and from container cooling in canning plants. The largest quantity of organic pollutants is from rinse sprays associated with chemical fruit cleaners, fungicides, and waxes (National Canners Association, 1974). 
Table 4. Effluent Limitations Guidelines (Wastewater Discharges) (CFR, 1999).

\begin{tabular}{|l|l|l|}
\hline \multirow{2}{*}{ Effluent Characteristic } & \multicolumn{2}{|c|}{ Effluent Limitation } \\
\cline { 2 - 3 } & \multicolumn{1}{|c|}{ Maximum for any 1 day } & $\begin{array}{c}\text { Average of Daily Values for } \\
\text { 30 Consecutive Days Shall } \\
\text { Not Exceed }\end{array}$ \\
\hline BOD (lb/ton raw ingredient) & 0.80 & 0.40 \\
\hline TSS (lb/ton raw ingredient) & 1.70 & 0.85 \\
\hline $\mathrm{pH}$ & Within the range 6.0 to 9.0 & Within the range 6.0 to 9.0 \\
\hline
\end{tabular}

1) Last amended to CFR 40, Section 401.32 was made on June 29, 1995.

Table 5. Disposal Sites and Volumes of Food Processing Wastewater Including the Citrus Industry (Adapted from Katsuyama, 1979).

\begin{tabular}{|c|c|c|c|c|c|c|}
\hline \multirow[b]{2}{*}{ DISPOSAL TO: } & \multicolumn{2}{|c|}{ Process Water } & \multicolumn{2}{|c|}{ Clean Water } & \multicolumn{2}{|c|}{ Total } \\
\hline & Bil. Gal. & $\%$ & Bil. Gal. & $\%$ & Bil. Gal & $\%$ \\
\hline \multicolumn{7}{|c|}{ SIC 203 Plants (Fruits, Vegetables, Juices) } \\
\hline POTW & 43 & 51 & 9 & 30 & 52 & 46 \\
\hline Water Body & 16 & 19 & 16 & 53 & 32 & 28 \\
\hline Land & 25 & 30 & 5 & 17 & 30 & 26 \\
\hline Total & 84 & 100 & 30 & 100 & 110 & 100 \\
\hline
\end{tabular}

SIC: Standard Industrial Classification

Bil. Gal: Billion gallon 
Table 6. Wastewater and Pollutant Load from Fresh Citrus Operations (Adapted from USEPA, 1974).

\begin{tabular}{|l|l|l|l|l|}
\hline Operation & Volume (mgd) & BOD (lb/day) & SS (lb/day) & TDS (lb/day) \\
\hline Washing & $0.15-0.50$ & $500-3000$ & $500-4000$ & $300-1500$ \\
Belt Conveyors & $0.20-0.10$ & $30-100$ & $100-200$ & $30-100$ \\
Sizing & $0.02-0.15$ & $50-600$ & $150-700$ & $100-500$ \\
Plant Cleanup & $0.60-0.20$ & $320-1200$ & $500-4000$ & $320-1000$ \\
Total & $0.97-2.10$ & $900-5000$ & $1250-8900$ & $750-3100$ \\
Average & $\mathbf{1 . 5 4}$ & $\mathbf{2 9 5 0}$ & $\mathbf{5 0 7 5}$ & $\mathbf{1 9 2 5}$ \\
\hline
\end{tabular}

mgd: Million gallon per day

BOD: Biochemical Oxygen Demand

SS: Soluble Solids

TDS: Total Dissolved Solids

Table 7. Water Used, Wastewater, and Pollution Loads Generation

(Adapted from National Canners Association, 1974).

\begin{tabular}{|c|c|c|c|c|c|c|c|c|c|c|c|c|c|c|c|}
\hline \multirow[b]{2}{*}{\begin{tabular}{|l} 
PROCESS \\
TYPE
\end{tabular}} & \multicolumn{4}{|c|}{$\begin{array}{c}\text { Water Used } \\
(1000 \mathrm{gal} / \text { ton })\end{array}$} & \multicolumn{3}{|c|}{$\begin{array}{c}\text { Wastewater } \\
(1000 \\
\text { gal/ton })\end{array}$} & \multicolumn{3}{|c|}{$\begin{array}{c}\text { BOD } \\
\text { (lb/ton) }\end{array}$} & \multicolumn{3}{|c|}{$\begin{array}{c}\text { SS } \\
\text { (lb/ton) }\end{array}$} & \multirow{2}{*}{\begin{tabular}{|c|}
$\begin{array}{c}\text { Temp. } \\
\left({ }^{\circ} \mathrm{F}\right)\end{array}$ \\
$\mathrm{AVG}$
\end{tabular}} & \multirow{2}{*}{\begin{tabular}{|c|}
$\mathbf{p H}$ \\
\\
$A V G$ \\
\end{tabular}} \\
\hline & $\mathrm{F}$ & $\mathrm{R}$ & $G$ & $\%$ & AVG & $95 \%$ & Limits & AVG & $95 \%$ & Limits & AVG & $95 \%$ & Limits & & \\
\hline Fresh Fruit & 8.5 & 2.6 & 11.1 & 30.6 & 7.3 & 1.4 & 24 & 250 & 6 & 240 & 335 & 2.7 & 332 & 75 & 6.5 \\
\hline $\begin{array}{l}\text { Concentrate } \\
\text { (1) }\end{array}$ & 2.5 & 0.1 & 2.6 & 4.0 & 4.3 & 0.4 & 16 & 50 & $(1$ & $45)^{\circ}$ & 14 & $(1$ & $10)^{\bullet}$ & 79 & 6.5 \\
\hline Juice & 3.0 & 0.2 & 3.2 & 5.0 & 4.3 & 0.4 & 16 & 50 & $(1$ & $45)^{\circ}$ & 15 & $(1$ & $10)^{\circ}$ & 79 & 6.5 \\
\hline
\end{tabular}

(1) Citrus Concentrate: Also 1.7, 0, 1.7,2.4 for evaporation AVG: Average

BOD: Biochemical Oxygen Demand

F: Fresh Intake Water

${ }^{\circ} \mathrm{F}$ : Degrees Fahrenheit

$\mathrm{G}$ : Gross applied Water $(\mathrm{F}+\mathrm{R})$

$R$ : Water Reused (among operations) and recirculated (within operation)

SS: Soluble Solids

$\%$ : Percent of Water Reused or Recirculated (R/G)*100

Limits in Parentheses are Reported Maxim and Minim 
Pesticides have been used in the USA commercially since 1940. This marked the industrial development of pesticides, which were initially considered relatively benign when compared to their predecessors, such as arsenic and copper, prior to World War II. Agricultural activities were some of the last regulated sources of contamination until 1969 when the state of Wisconsin won a case against the use of DDT. Federal regulations were implemented through the Federal Environmental Pesticide Control Act, which was approved by 1972 . This act gave authority to the USEPA to regulate pesticides, for both environmental level and human health. Throughout the 1970s, agricultural chemicals occupied much of the environmental movement's attention. During the 1980s, "green" forces became stronger and the agenda of environmental organizations focused on agriculture activity. During the 1990 s, the rise of the "green movement" created a very high level of pressure to reduce pesticide use (Lehman et al., 1993).

Farmers are being forced to use pesticides in the agrochemical age to solve production problems. As a consequence of mechanization and new technologies, pests, pathogens, nematodes, fungus, and weed problems began to exacerbate, creating decreasing species diversity (monoculture) in impacted ecosystems. Figure 3 shows the context and cycle of pesticides use, in nature and society. The increasing uses of pesticides in agriculture produce an urgent need to prevent or reduce the movement of chemicals into the environment and foods. Even though efforts to protect ecosystems from pesticide residues are ongoing, federal and state government agencies cannot fully control the problem (Truhant, 1977). 


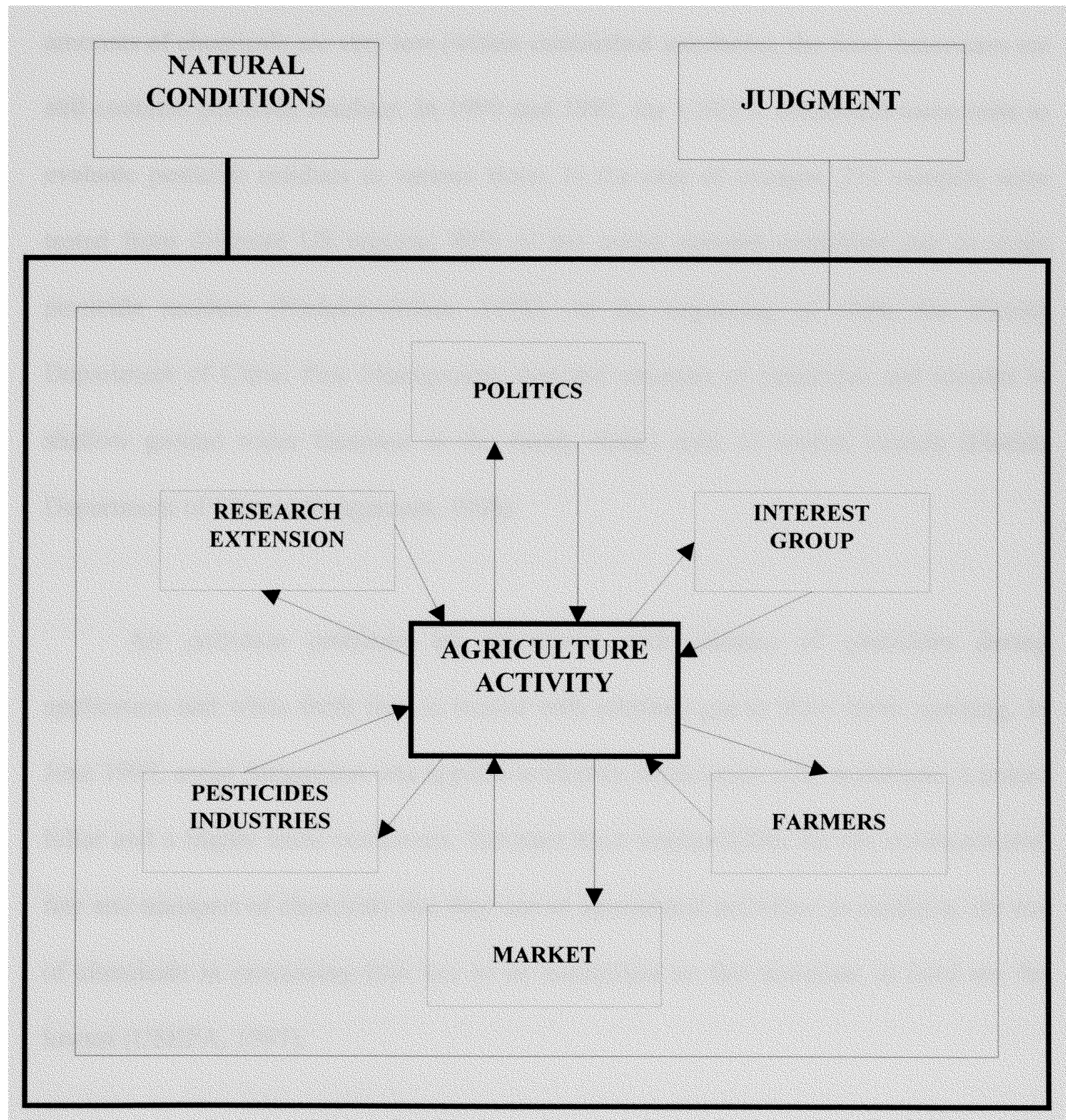

Figure 3. Relationship between Pesticides, Nature and Society (Adapted from Truhant, 1977). 
In 1987 the National Research Council of the National Academy of Sciences reported a warning regarding the increasing number of cancer mortalities among Americans because of the ingestion of certain pesticide residues on food. Even though the amounts of chemicals are very low (within established standards), the food Americans eat still contains pesticide residues. In 1990 and 1992, the USEPA conducted some tests to evaluate pesticide residues in various fruits. In the case of oranges, 237 samples were tested from different US regions; $80 \%$ of the tested samples contained one or more pesticide residues (Nadakavukaren, 1995). At the beginning of 1996, the Florida Department of Citrus Pest Management detected amounts of pesticides and nitrates in shallow ground water locations in the Sandy Ridge soils of central Florida (Florida Department of Citrus Management, 1996).

Air pollution problems are associated with releases of pesticides during application and while fresh fruit is treated with ethylene gas to slow down ripening. In June 1997, aerial fumigation was applied to Florida citrus crops with malathion, a potent foliar and a highly toxic compound. Growers have responsibility for the environmental fate and transport of chemicals that they use in agricultural activities. In addition, the use of chemicals in processing fruit has to be minimized so that residuals in food are the lowest (USEPA, 1997).

Solid wastes originate from washing, sorting, grading, and packing processes. Solid wastes include dirt, leaves, stems, hulls, off-grade fruits, and other miscellaneous 
rejected materials. These wastes are organic and highly perishable in nature. Unused fruit and other solid wastes in central packing operations can cause fly and rodent problems, unpleasant odors, and water pollution from leachate (USEPA, 1975).

\subsection{Synthetic Organic Compounds in Foods}

Human beings not only are exposed to natural substances that are basic components of the foods they eat but are also exposed to synthetic chemicals such as residues from fertilizers, pesticides, and antibiotics, which become part of the food, water supplies, and the atmosphere (Foulke, 1991). The USEPA, under stipulations of the Delaney Clause of the Federal Food, Drug and Cosmetic Act (FFDCA), has the authority to establish tolerances or maximum allowable levels, for pesticide residues in foods. This authority is granted in Sections 408 and 409 of the FFDCA. Under Section 408, the USEPA determines appropriate tolerances for pesticide residues in raw agricultural commodities, while Section 409 applies to pesticide residues in processed foods, which are treated as food additives (Winter, 1993). Regarding Section 408, the USEPA considers that pesticide tolerances for agricultural commodities have to be treated in a similar way, if the land is destined either for agricultural production of fresh fruit or for food to be processed. The USEPA has presented a list of pesticides that need evaluation in order to find their toxicology and residue data in the citrus industry (see Table 8) (USEPA, 1993). 
Table 8. Pesticides Considered by the Court of Appeals Ruling (Adapted from USEPA, 1993).

\begin{tabular}{|l|l|l|}
\hline \multicolumn{1}{|c|}{ Pesticide } & \multicolumn{1}{c|}{$\begin{array}{c}\text { Raw Commodity } \\
\text { (Section 408 Tolerance) }\end{array}$} & \multicolumn{1}{c|}{$\begin{array}{c}\text { Processed Form } \\
\text { (Section 409 Tolerance) }\end{array}$} \\
\hline Benomyl & Citrus & Pulp (dried) \\
\hline Dicofol & Citrus & Oil \\
\hline Dimethoate & Citrus & Oil \& Pulp (dried) \\
\hline Maneb & Citrus & Oil \\
\hline Norflurazon & Citrus & Dried Hops, Molasses \& Pulp \\
\hline Phosmet & Citrus & Oil \\
\hline Propargite & Citrus & Oil \\
\hline
\end{tabular}




\section{ASSESSMENT APPROACHES}

A framework method is needed to conduct pollution prevention (P2) assessments in the citrus industry. This method follows basic approaches of $\mathrm{P} 2$ opportunities, which include quantification of waste streams, identification of pollution prevention opportunities, suggestion and evaluation of alternative opportunities, and introductory guidance to implement these opportunities. These approaches intend to provide guidance for an integrated use of this study as a general guide to conduct P2 assessments and to become ISO 14000 certified (USEPA, 1992a).

\subsection{Pollution Prevention (P2) Assessment}

The U.S. Federal Pollution Prevention Act of 1990 (U.S. Code 1993, Title 42) defines pollution prevention as "the use of materials, processes, or practices that reduce or eliminate the creation of pollutants or wastes at the source, including reduction of hazardous and nonhazardous materials, energy, water, or other resources to protect natural resources through conservation or more efficient use." Figure 4 presents a basic framework for the citrus industry to conduct P2 assessments. The guidelines to be considered are pre-assessment survey, waste stream characterization, pollutant quantification, mass balances and in the implementation phase of the P2 program, evaluation of P2 program, cost evaluation, results, and compliance, savings, and recognition during the payback period (USEPA, 1992a). 


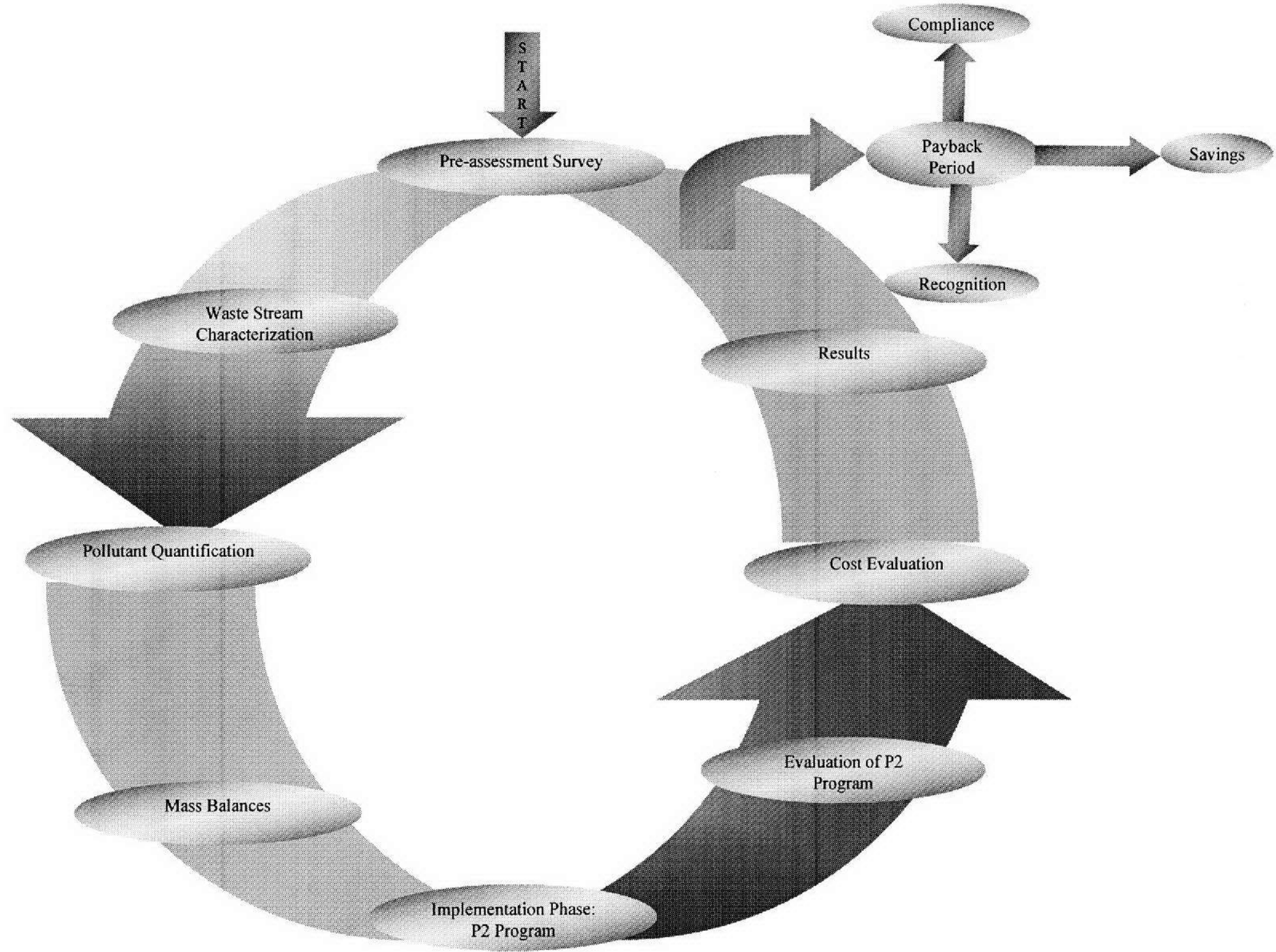

Figure 4. Pollution Prevention Assessment Diagram

(Adapted from USEPA, 1996 and USEPA, 1992). 
The following definitions of the guidelines to conduct a pollution prevention assessment in the citrus industry are based on specifications presented in the "Facility Pollution Prevention Guide” (USEPA, 1992a).

\subsubsection{Pre-assessment survey}

The pre-assessment survey gathers background information, identifies potential opportunities, and evaluates those opportunities to reduce wastes. During this phase the industry identifies hazardous substances, pollutants, or any contaminants that the industry is discharging, releasing, and/or disposing in any environmental medium (air, land, and water). At this point, the industry starts planning employee training required for implementing the P2 program. This phase screens waste reduction option, evaluating technical, economical, and environmental approaches to identify ways to reduce costs associated with waste generation and disposal. These results are used to select more suitable options for future implementation. Preliminary costs are collected to be included during the cost evaluation analysis after implementation of the P2 program.

\subsubsection{Waste stream characterization}

The main point to remember when conducting P2 assessments is to consider all waste streams, whether or not they are regulated or require an environmental permit. Characterization of waste streams not only include wastes that agricultural activities and 
the industry operations will generate but also wastes that will be created after final products are consumed. Energy, water, and other natural resources should also be considered when starting to explore methods for reducing or recycling waste streams.

\subsubsection{Pollutant quantification}

Pollutant quantification includes physical measurement of existing processes and projection of future waste streams after updating processes. For existing processes, direct measurements are used. Future waste stream projections are based on vendors, data or preliminary calculations and operating parameters.

\subsubsection{Mass balances}

Mass balances are based on quantification of materials produced, consumed, used, or accumulated in the industry operating processes. It also accounts for all releases of materials from processes as waste streams, commercial product, or byproducts. Mass balances are useful to prioritize and establish boundaries to minimize waste streams during the implementation of the $\mathrm{P} 2$ program. Boundary conditions must include a time frame and conditions under which data were collected. 


\subsubsection{Implementation phase: pollution prevention program}

During this phase, all procedures, employee training, and equipment changes are implemented to reduce waste streams. The P2 assessment implementation phase demonstrates the industry capabilities to optimize the use of resources, minimize nonproduct-related losses, and increase productivity.

\subsubsection{Evaluation of pollution prevention program}

The evaluation of the $\mathrm{P} 2$ program is defined as a continual cycle reviewing and improving the actions that an organization implemented during the $\mathrm{P} 2$ program designed for the industry to minimize waste streams generation and to meet environmental obligations.

\subsubsection{Cost evaluation}

The cost evaluation phase compiles all costs associated with the implementation of the P2 program, including operating costs (treatment, disposal, raw materials), decreased productivity (losses often indicate inefficient processes), implementation of the new $\mathrm{P} 2$ program, savings after the $\mathrm{P} 2$ program is implemented, and economic and environmental benefits after implementation of the P2 program. Potential waste reduction savings should be included. The study suggests a simplified worksheet for a prevention- 
of-pollution preliminary assessment, which is reported under Chapter 6, Section 6.2.2.6, Table 38.

\subsubsection{Payback period}

The payback period is defined as the period of time (e.g., weeks, months, years) necessary to recover the initial investment exactly. The payback method to calculate the payback period is given by the following equation:

$$
\text { Payback Period }=\frac{\text { Implementation Cost of P2 Assessment Program }}{\text { Annual Cash Inflow }}
$$

\subsubsection{Results}

Results include all P2 recommendations to improve operating practices, material substitutions, equipment changes, process modifications, and recycling options. The cost evaluation worksheet (see Table 38) for the industry with formal calculations needs to be included. A written report is generated compiling all stages of the P2 assessment for guiding the program through the development stages. 


\section{Table 9. Pollution Prevention Regulatory Requirements}

(Adapted from USEPA, 1992a).

\begin{tabular}{|l|l|}
\hline \multicolumn{1}{|c|}{ Regulation } & \multicolumn{1}{|c|}{ Description } \\
\hline $\begin{array}{l}\text { Pollution Prevention Act of } \\
1990\end{array}$ & $\begin{array}{l}\text { To establish the P2 hierarchy (source reduction, } \\
\text { recycling, treatment, and disposal) to prevent pollution } \\
\text { at the source as much as possible instead of relying on } \\
\text { final waste treatment or disposal. Source reduction and } \\
\text { recycling initiatives shall be considered. }\end{array}$ \\
\hline $\begin{array}{l}\text { Resource Conservation and } \\
\text { Recovery Act of 1976 (RCRA) }\end{array}$ & $\begin{array}{l}\text { To certify that industry has a program in place to } \\
\text { reduce volume and toxicity of waste, during } \\
\text { agricultural activities mainly, and to certify that } \\
\text { methods used for treatment, storage, and disposal } \\
\text { (TSD) are appropriate to minimize waste generation. }\end{array}$ \\
\hline $\begin{array}{l}\text { Clean Air Act (CAA) of 1970 } \\
\text { and 1990 Amendments }\end{array}$ & $\begin{array}{l}\text { To direct industries to consider P2 alternatives to } \\
\text { minimize air contamination. Guidelines for industrial } \\
\text { standards are included. }\end{array}$ \\
\hline $\begin{array}{l}\text { Clean Water Act (CWA) of } \\
1977 \text { and Amendments }\end{array}$ & $\begin{array}{l}\text { To direct industries to consider P2 alternatives to } \\
\text { minimize industrial water effluents. Guidelines for } \\
\text { industrial standards are included. }\end{array}$ \\
\hline
\end{tabular}




\subsection{Major Regulatory Requirements}

From the regulatory standpoint, citrus industries have to comply with some major regulatory requirements for $\mathrm{P} 2$ assessments since they are often major federal agency targets. Table 9 summarizes general regulatory requirements for $\mathrm{P} 2$ assessments in the citrus industry.

\subsection{International Standards Organization (ISO 14000)}

Following the scope of ISO 9000, international standards deal with quality systems. ISO 14000 incorporates environmental aspects into operation and product standards. The purpose of ISO 14000 is to demonstrate environmental performance of an organization by controlling the impact of their activities, products, or services on the environment in accordance with their environmental policy and objectives (Tibor and Feldman, 1996).

Regarding prevention-of-pollution issues, ISO 14000 includes creation and implementation of environmental policies to specific targets, integration of environmental considerations in operating procedures, employee training versus environmental obligations, and conducting of audits of the ISO 14001 EMS (Kinsella, 1994). 
ISO 14000 is being developed by the International Standards Organization (ISO) Technical Committee (TC) 207. TC 207's objective is to standardize management tools and systems in the environmental field that help all types of organizations to implement the system easily. ISO 14000 focuses on product and organizational standards. ISO 14000 covers two environmental standards, each of them includes three guidance documents as follow:

- Organizational Evaluation Standards: Environmental Management Systems (EMS), Environmental Auditing, and Environmental Performance Evaluation (EPE).

口 Production Evaluation Standards: Environmental Aspects in Product Standards (EAPS), Life Cycle Assessment (LCA), and Environmental Labeling.

\subsubsection{Environmental Management Systems (EMS)}

Three aspects constitute the EMS:

1) A written program that commits the company to produce the highest quality product with the lowest possible environmental impact, including prevention of noncompliance with environmental regulations.

2) Education and training, which makes the program more effective by making employees understand the EMS.

3) Knowledge of relevant local and federal environmental regulations that apply to each specific facility (Kinsella, 1994 and Quinn, 1997). 


\subsubsection{Environmental Auditing}

The American National Standard Institute (ANSI) defines environmental auditing as "a systematic, documented verification process of objectively obtaining and evaluating audit evidence to determine whether specific environmental activities, events conditions, management systems or information about these matters conform with audit criteria, and communicating the results of this process to the client."

Environmental auditing refers to a routinely evaluation on an organization environment control. This evaluation is conducted by a third party and includes inputs (raw materials, energy) and outputs (waste streams, emissions) for the system of concern (ANSI, 1997).

\subsubsection{Environmental Performance Evaluation (EPE)}

The environmental performance evaluation quantifies the impact an organization is having on the environment. This evaluation is determined by an inventory of pollutants impacting environmental compartments such as water, air, and soil. The main objective of this inventory is to identify contaminant indicators and loading and to implement possible solutions (Capaccio, 1999). 


\subsubsection{Environmental Aspects in Product Standards (EAPS)}

\subsubsection{Life Cycle Assessment}

The life cycle assessment covers manufacture, operation, and disposal of any product. The manufacturing operation looks to substitute harmful products for less harmful or environmentally friendly ones, minimizing the waste stream. The operation activity covers any waste generated during this process and the path to minimize that generation by improvement of the operational system. The disposal of the product deals with the safest environmental opportunities to return the product at the end of its life cycle to the environment (Tibor and Feldman, 1996).

It is important to characterize and assess prevention-of-pollution opportunities within the framework of Product Life Cycle Management concepts or an "Eco-product Design Approach." To be compatible with the "Eco-product Design Approach," the study identified prevention-of-pollution options that industry should consider. The Eco-product Design Approach, if applied to the citrus industry, would ensure responsibility for the environmental effects throughout a product's life cycle. To assess the impact and its potential reduction on the environment, the following aspects of the citrus industry should be addressed:

- pollution assessment of the citrus industry as a whole

口 potential multimedia effects on water, soil, air, and living organisms 
$\square$ available tolerance levels of contaminants

- final destination of citrus crop after harvesting (i.e., fresh fruit or processed product)

ㅁ potential human exposure based on average dietary consumption patterns

- potential effect of citrus contamination in agriculture, industry, and public market.

\subsubsection{Environmental labeling}

Environmental labeling manages environmental friendly products meeting consumers' needs. This standard encourages manufacturers to reduce the environmental impact of products and to inform consumers about products' environmental performance. The products are identified with a green label scheme or friendly label. Europe is leading in the world; the European Community (EC) adopted an Eco-Label regulation in 1992 (Harmon, 1994).

The implementation of ISO 14001 EMS implies that an organization establish an environmental policy, determining environmental aspects and impacts of products, activities, and services. The organization must also plan environmental objectives to measure targets with the implementation of operational programs. Finally, process and procedures must be checked, corrective actions taken, and management reviewed (Harmon, 1994 and Quinn, 1997). 
Organizations looking to implement ISO 14000 will evaluate the impact that an Environmental Management System (EMS) will have on its internal structure and its ability to provide the comprehensiveness required to meet external expectations. The management of environmental issues has changed from one of reaction to regulation, compliance driven, to voluntarily meeting environmental goals and objectives. This vision of proactive environmental management is the focus behind ISO 14000 (Quinn, 1997).

The ISO 14000 standards are designed to provide an internationally recognized framework for environmental management, measurement, evaluation and auditing. They are voluntary initiatives from each organization and do not intend to appoint environmental performance targets, but instead provide organizations with the tools to assess and control the environmental impact of their activities, products or services (ANSI, 1997).

Table 10 illustrates the voluntary series that have been developed to assist organizations on becoming ISO 14000 certified. The standards are flexible enough to be used by any organization of any size since they are designed to be internationally and applicable to any field (ANSI, 1997). 
Table 10. The ISO 14000 Series

(Adapted from ANSI, 1999).

\begin{tabular}{|c|c|c|}
\hline $\begin{array}{c}\text { Document } \\
\text { Number: Year }\end{array}$ & Document Title & Comments \\
\hline ISO 14001:1996 & $\begin{array}{l}\text { Environmental Management Systems } \\
\text { (EMS) }\end{array}$ & Specification with guidance for use. \\
\hline ISO 14004:1996 & Environmental Management Systems & $\begin{array}{l}\text { General guidelines on principles, } \\
\text { systems and supporting techniques. }\end{array}$ \\
\hline ISO 14010:1996 & Guidelines for environmental auditing & General principles. \\
\hline ISO 14011:1996 & Guidelines for environmental auditing & $\begin{array}{l}\text { Audit procedures - Part 1: Auditing } \\
\text { of environmental management } \\
\text { systems. }\end{array}$ \\
\hline ISO 14012:1996 & Guidelines for environmental auditing & $\begin{array}{l}\text { Qualification criteria for } \\
\text { environmental auditors. }\end{array}$ \\
\hline ISO 14020:1998 & Environmental labels and declarations & General principles. \\
\hline ISO 14021:1999 & Environmental labels and declarations & $\begin{array}{l}\text { Self-declared environmental claims } \\
\text { (Type II environmental labeling). }\end{array}$ \\
\hline ISO 14024:1999 & Environmental labels and declarations & $\begin{array}{l}\text { Type I environmental labeling - } \\
\text { Principles and procedures. }\end{array}$ \\
\hline ISO 14031:1999 & Environmental management & $\begin{array}{l}\text { Environmental performance } \\
\text { evaluation - Guidelines. }\end{array}$ \\
\hline ISO 14040:1997 & Environmental Management & $\begin{array}{l}\text { Life cycle assessment - Principles } \\
\text { and framework. }\end{array}$ \\
\hline ISO 14041:1998 & Environmental management & $\begin{array}{l}\text { Life cycle assessment - Goal and } \\
\text { scope definition and inventory } \\
\text { analysis. }\end{array}$ \\
\hline ISO 14050:1998 & Environmental management & Vocabulary. \\
\hline ISO Guide $64: 1997$ & $\begin{array}{l}\text { Guide for the inclusion of } \\
\text { environmental aspects in product } \\
\text { standards. }\end{array}$ & $\begin{array}{l}\text { Covers the considerations of } \\
\text { environmental impacts in product } \\
\text { standards. }\end{array}$ \\
\hline \multicolumn{3}{|c|}{ International Standards - Drafts } \\
\hline ISO/DTR 14032 & Environmental management & $\begin{array}{l}\text { Examples of Environmental } \\
\text { Performance Evaluation (EPE). }\end{array}$ \\
\hline ISO/DIS 14042 & Environmental management & $\begin{array}{l}\text { Life Cycle Assessment - Impact } \\
\text { assessment. }\end{array}$ \\
\hline ISO/DIS 14043 & Environmental management & $\begin{array}{l}\text { Life cycle assessment - } \\
\text { Interpretation. }\end{array}$ \\
\hline ISO/DTR 14049 & Environmental management & $\begin{array}{l}\text { Life Cycle Assessment - Examples } \\
\text { of applications of ISO } 14041 \text { to } \\
\text { goal and scope definition and } \\
\text { inventory analysis. }\end{array}$ \\
\hline
\end{tabular}




\section{LITERATURE REVIEW}

\subsection{Industry Characterization}

Citrus is originally from the Malay Archipelago and Southeast Asia. It spreaded westward to India and the Mediterranean before Columbus brought the first seed to the new world (Haiti). The exact date of introduction of citrus seeds in Florida is unknown, but Pedro Mendez noted on April 2, 1579, that there was growth in abundance in the St. Augustine area. Florida's first cultivated grove was planted in Pinellas County sometime between 1803 and 1820. Florida has more than 14,000 citrus growers, cultivating a record 92 million citrus trees on more than 790,000 acres (Florida Department of Agriculture and Consumer Services, 1993).

Statistics from the Florida Department of Agriculture and Consumer Services show the development and importance of the citrus industry in Florida (see Table 11). The principal types of citrus in the world are represented in Figures 5, 6, and 7, which show fresh orange, grapefruit, and lemon production. These statistics place the USA as one of the main citrus producers in the world The USA has been increasing foreign exports to Canada, Japan, China, Singapore, Taiwan, and other countries. Canada accounts for the most receipts of Florida oranges, while Japan receives the most grapefruit. Figure 8 shows the different types of citrus produced during 1997 and 1998 (Florida Agricultural Statistics Service, 1999). 
Table 11. General Data on the Citrus Activity

(Florida Agricultural Statistics Service, 1999).

\begin{tabular}{|c|c|c|c|c|c|}
\hline $\begin{array}{l}\text { Citrus } \\
\text { Product }\end{array}$ & $\begin{array}{l}\text { Origin } \\
\text { Facts }\end{array}$ & $\begin{array}{c}\text { Florida \& } \\
\text { Production } \\
\text { Place in the } \\
\text { World } \\
\end{array}$ & $\begin{array}{c}\text { In \% of } \\
\text { Production } \\
\text { World }\end{array}$ & $\begin{array}{c}\text { Citrus } \\
\text { Primary } \\
\text { Varieties } \\
\text { in Florida }\end{array}$ & $\begin{array}{l}\text { Industrial } \\
\text { Products }\end{array}$ \\
\hline Grapefruit & $\begin{array}{l}\text { First brought } \\
\text { to the USA in } \\
1823\end{array}$ & Leader & 32.3 & $\begin{array}{l}\text { Foster } \\
\text { Redblush } \\
\text { Thompson } \\
\text { Marsh } \\
\text { Duncan }\end{array}$ & $\begin{array}{l}42.7 \% \text { was } \\
\text { shipped } \\
\text { fresh, the } \\
\text { rest was } \\
\text { processed } \\
\text { product }\end{array}$ \\
\hline Oranges & $\begin{array}{l}\text { First brought } \\
\text { in the } 16 \text { th } \\
\text { century }\end{array}$ & $\begin{array}{l}\text { Second largest } \\
\text { producer } \\
\text { following Brazil }\end{array}$ & 70 & $\begin{array}{l}\text { Navel } \\
\text { Hamlin } \\
\text { Pineapple } \\
\text { Orange } \\
\text { Valencia }\end{array}$ & $\begin{array}{l}\text { Fresh fruit } \\
\text { and } \\
\text { processed } \\
\text { product }\end{array}$ \\
\hline $\begin{array}{l}\text { Citrus } \\
\text { Juice }\end{array}$ & $\begin{array}{l}\text { Earliest } \\
1940 \text { s in } \\
\text { Florida }\end{array}$ & Second place & 82 & All above & $\begin{array}{l}98 \% \text { of all } \\
\text { orange } \\
\text { production }\end{array}$ \\
\hline
\end{tabular}

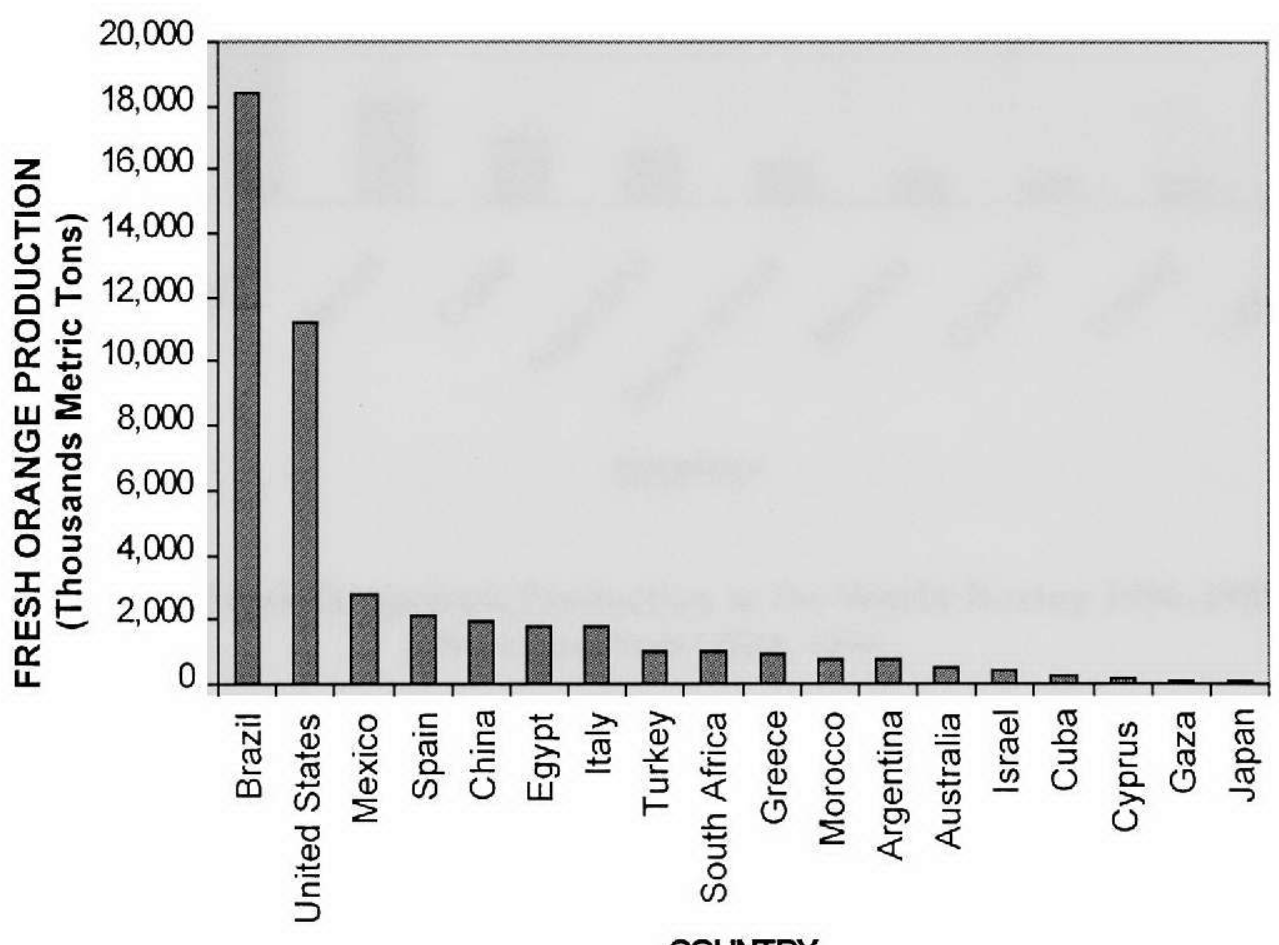

Figure 5. Fresh Orange Production in the World During 1996-1998

(Data adapted from USDA, 1999). 


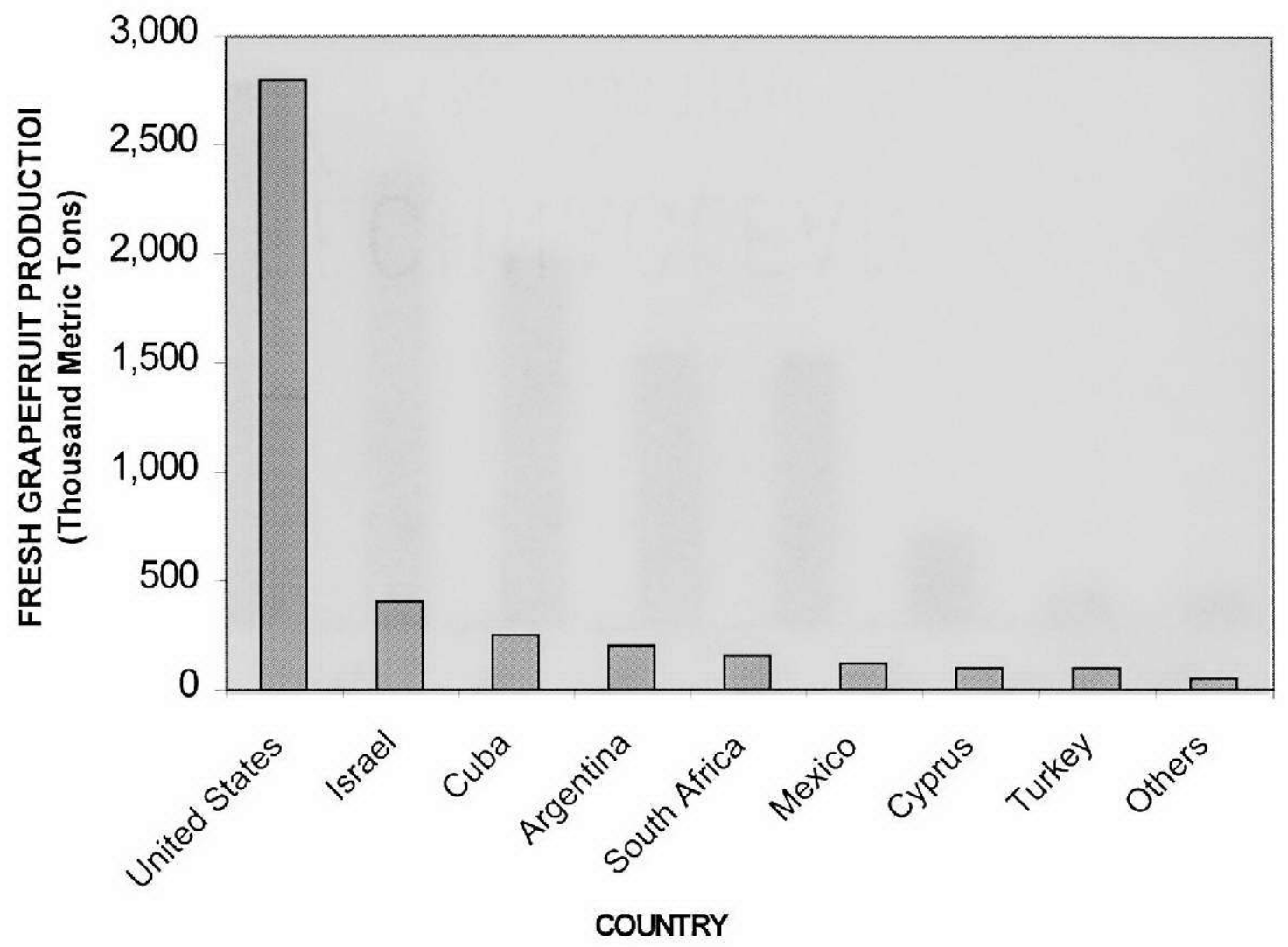

Figure 6. Fresh Grapefruit Production in the World During 1996-1998

(Data adapted from USDA, 1999). 


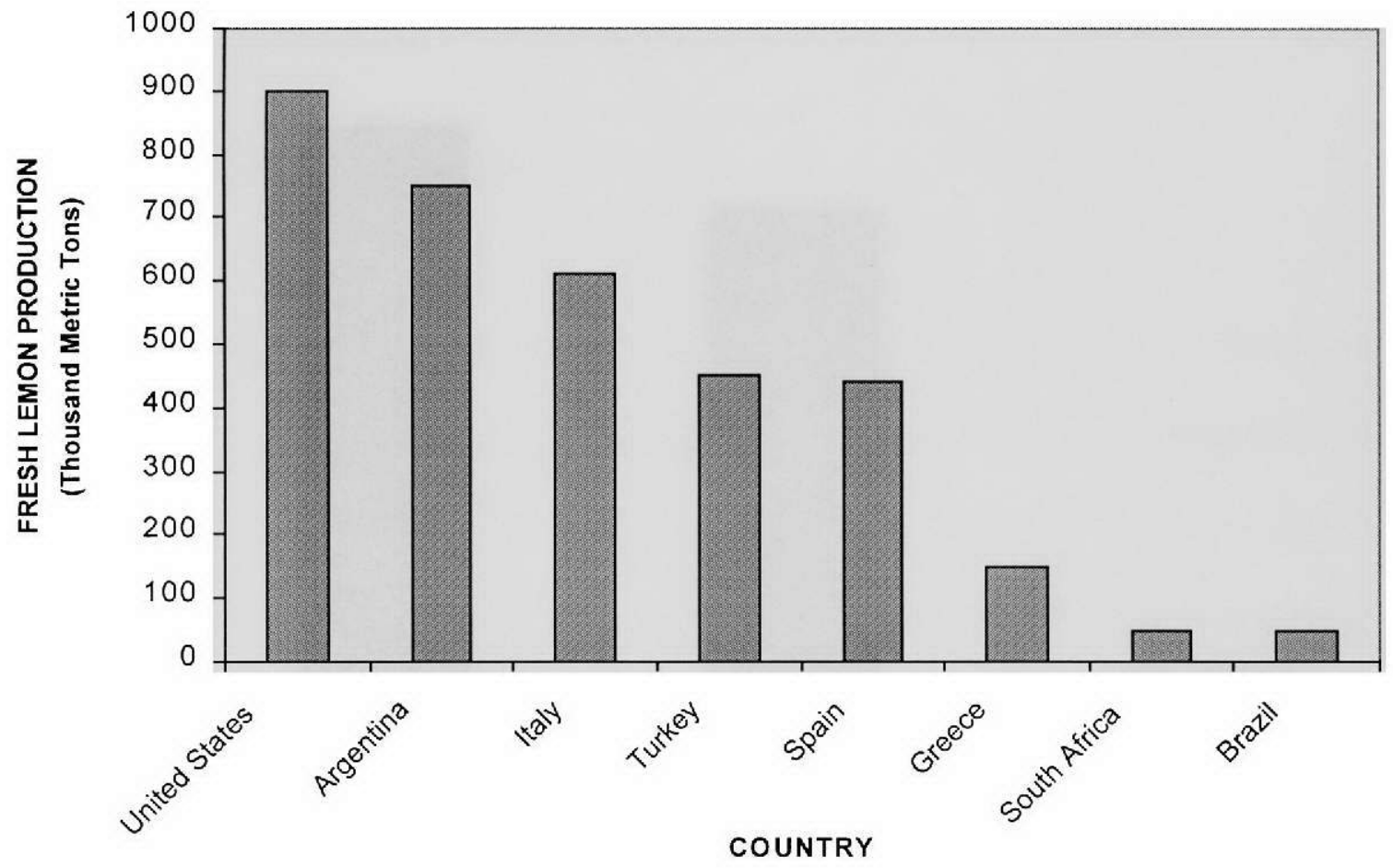

Figure 7. Fresh Lemon Production in the World During 1996-1998 (Data adapted from USDA, 1999). 


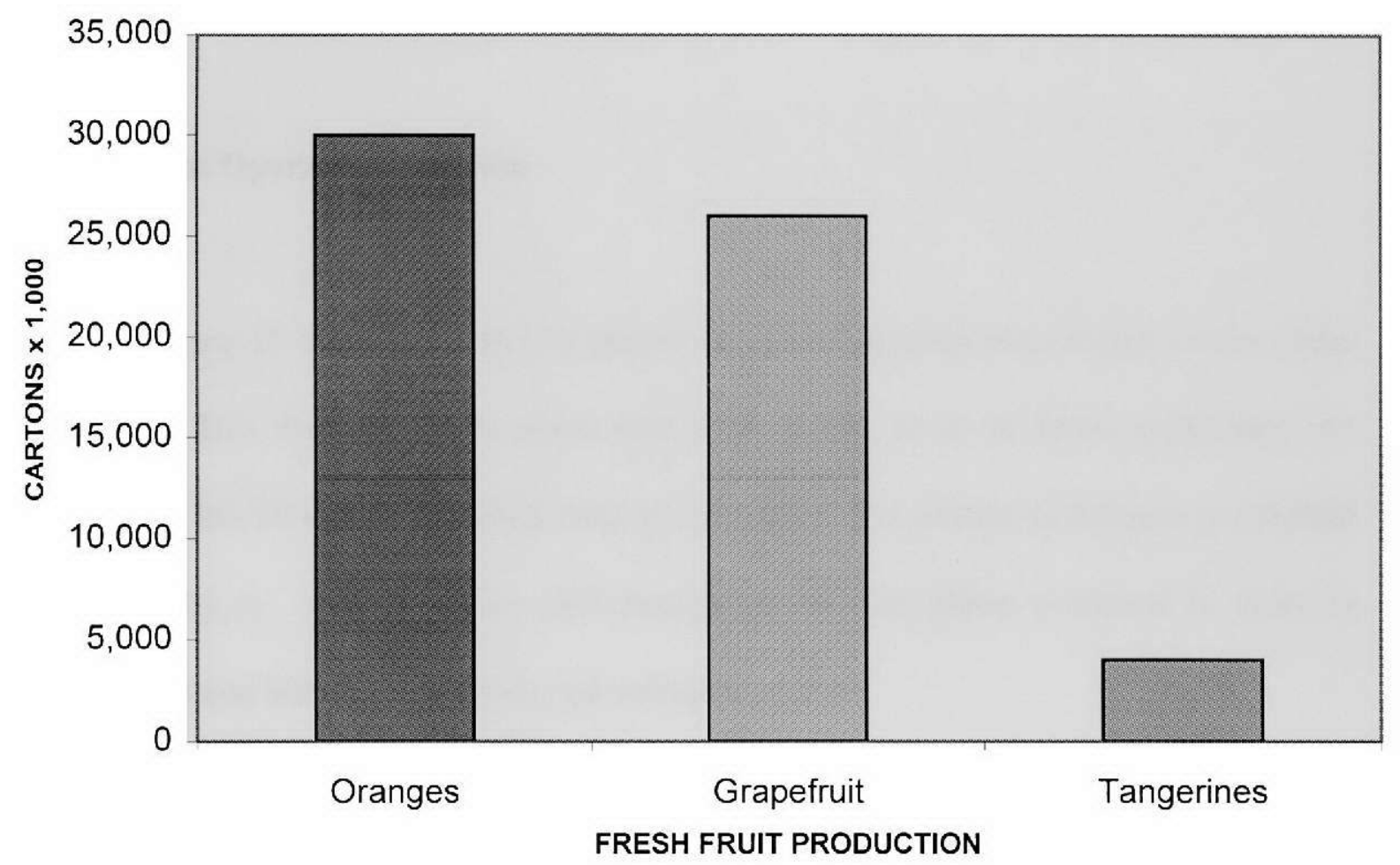

Figure 8. USA Fresh Citrus Exports 1997-1998

(Data adapted from USDA, 1999). 
Figure 9 represents Florida's more recent statistical export records. Besides fresh fruit, the USA and Florida also export fresh concentrate orange juice (FCOJ), mostly to Canada. During 1996-1998, a total of 22.6 million gallons of FCOJ were exported and 5.1 million gallons of fresh concentrate grapefruit juice (GCOJ) (National Agricultural Statistic Services, 1999).

\subsection{Unit Operation Diagram}

Figure 10 shows 15 different phases at which contamination occurs in the citrus industry. This diagram is illustrated with photographs so as to better understand the process. Chet Townsend provided these photographs. His written permission is attached in Appendix 1. A close review and description on each phase is critical in order to understand and identify operations and pollutant sources.

\subsubsection{Phase I}

\subsubsection{Pre-harvesting}

Marketing objectives are the main factors that move industry, so that high quality has to be offered in order to successfully compete. Pest control leads to quality fruit. For example, California and Texas have to attack red mites and rust mites, respectively, to achieve an acceptable cosmetic appearance since their primary market is fresh fruit (Becker et al., 1992). 


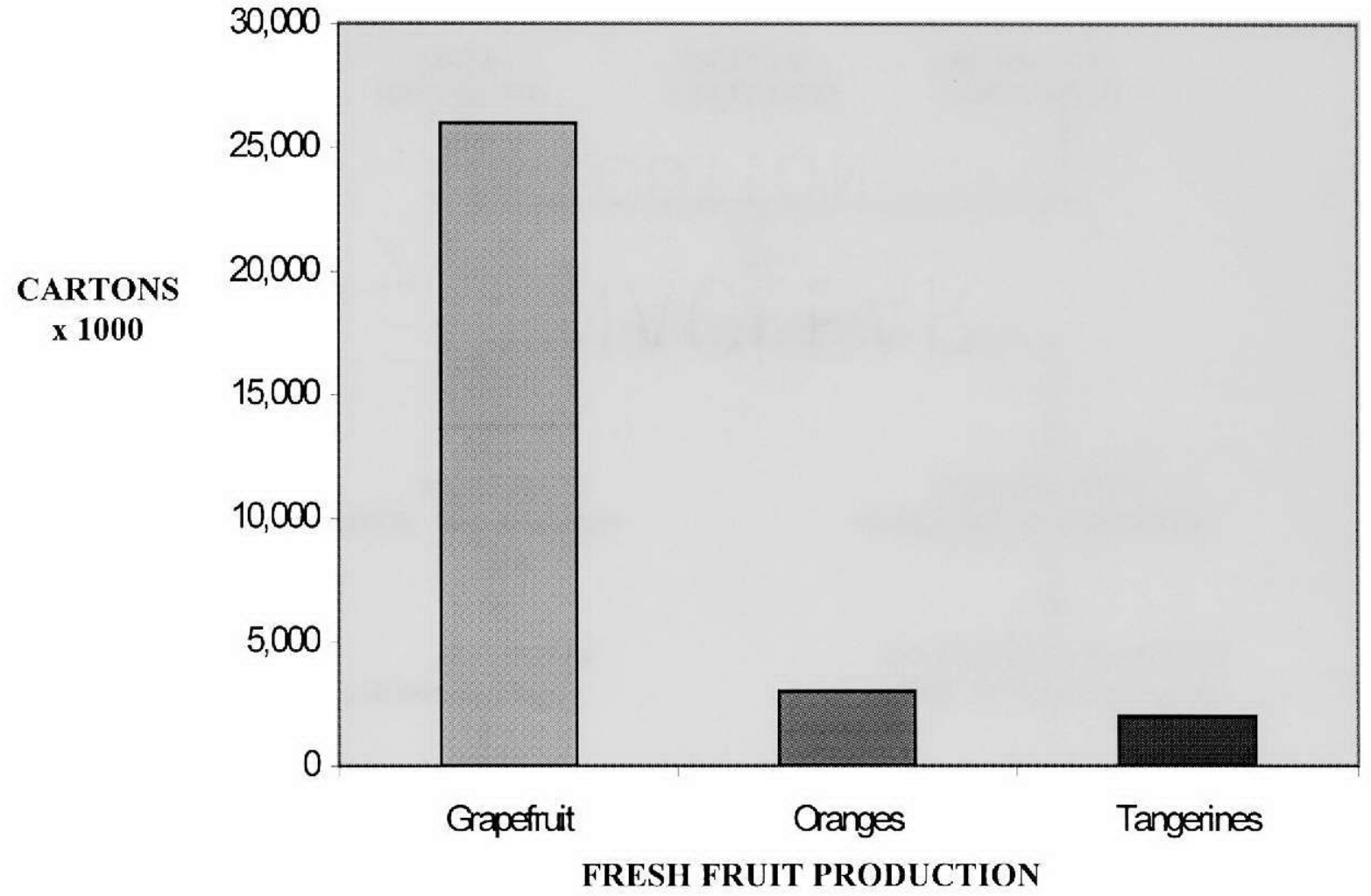

Figure 9. Florida Fresh Citrus Exports Contribution 1996-1998

(Data adapted from USDA, 1999). 


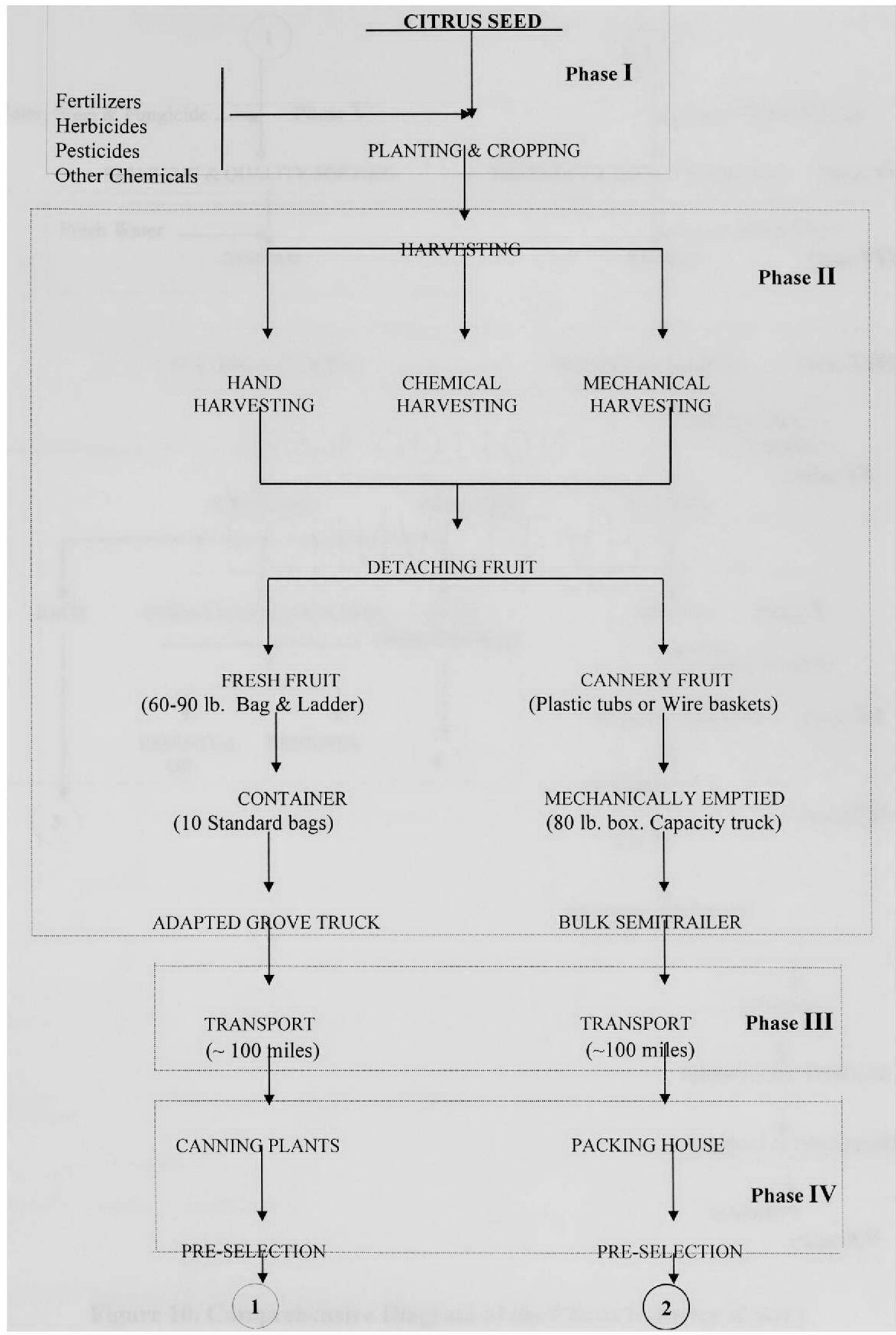

Figure 10. Comprehensive Diagram of the Citrus Industry. 


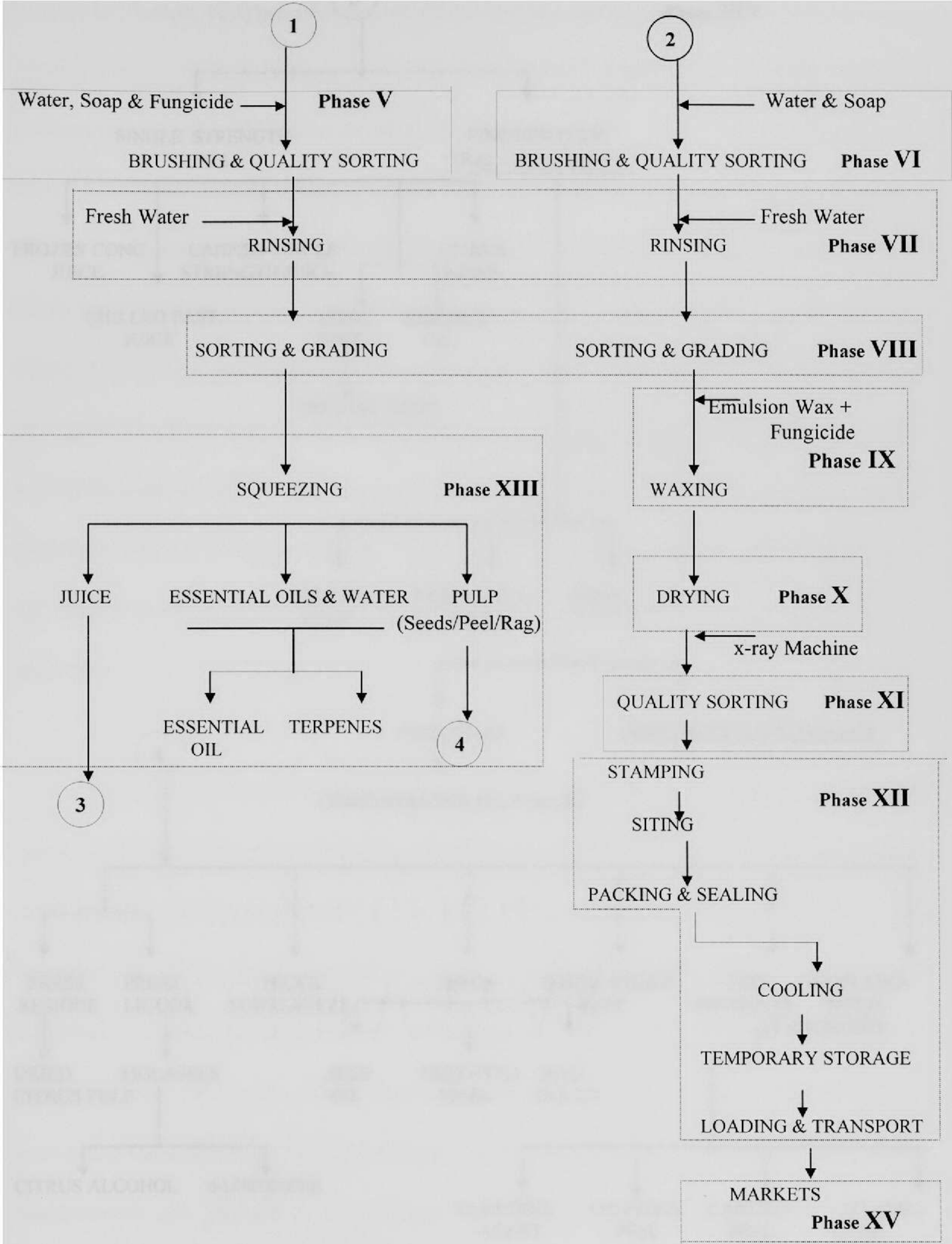

Figure 10. Comprehensive Diagram of the Citrus Industry (Cont.) 


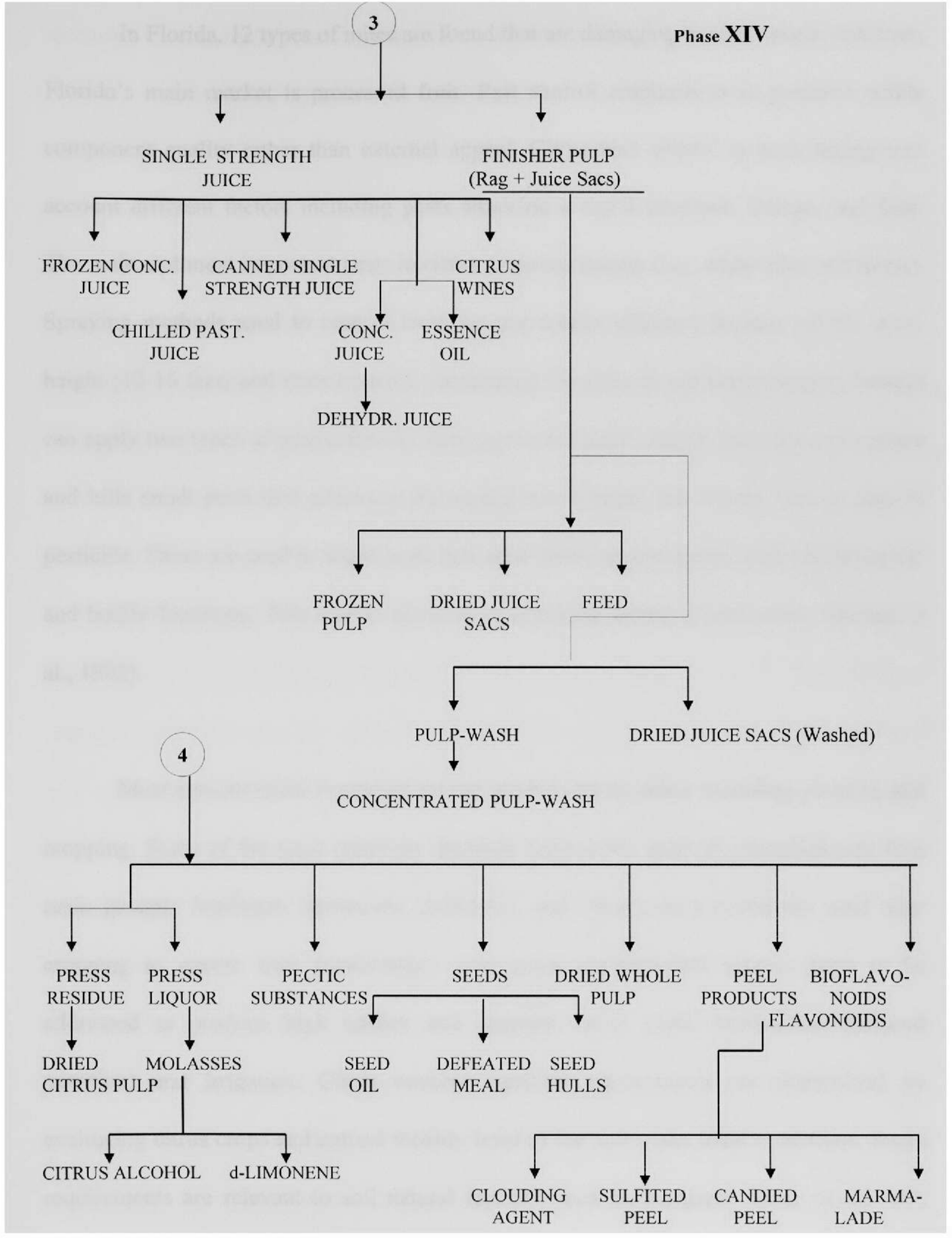

Figure 10. Comprehensive Diagram of the Citrus Industry (Cont.) 
In Florida, 12 types of mites are found that are damaging to citrus peels; however, Florida's main market is processed fruit. Pest control emphasis is to preserve edible component quality rather than external appeal. Citrus pest control is done taking into account different factors including pests attacking a tree's structure, foliage, and fruit. The main and most important pests in citrus crops are insects (i.e., white-flies and mites). Spraying methods used to control them are not totally effective because of the trees' height (12-16 feet) and their bootlick (denseness). In order to get better results, farmers can apply two types of pesticides: the first type is oil-based, which coats the tree surface and kills small pests that penetrate the treated tree surface; the second type is non-oil pesticide. These are used to target pests that need chemical interaction with physiological and bodily functions. This type is effective in attacking localized pest areas (Becker et al., 1992).

Most agrochemical is applied during pre-harvesting phase including planting and cropping. Some of the most common chemical compounds used are classified into four main groups: fertilizers, herbicides, pesticides, and other minor chemicals used after cropping to ensure fruit preservation. Two main agrotechnical aspects have to be addressed to produce high quality and quantity citrus yield, fertilization (mineral nutrition) and irrigation. Citrus mineral nutrition requirements are determined by evaluating citrus crops and natural fertility level of the soil under local conditions. Some requirements are relevant to soil natural fertility, such as inorganic status of the soil, microbiological activity, organic matter, moisture, aeration, etc. In addition, virus 
diseases, fungal organisms, capacity of rootstocks to absorb nutrients from the soil, climate conditions, and practices in soil irrigation affect the nutritional status needed (Minessy et al., 1973).

Three main methods are used to evaluate nutrients needed in citrus crops: fertilizer experiments, soil analysis, and plant analysis. Fertilizer experiments are of narrow use since the data obtained are only useful for specific crops and local areas where the experiment was conducted. Soil analysis even though it is not $100 \%$ accurate serves as a tool to model and interpret fertilizer experiment results from one site to another. However, soil analysis does not report any information regarding nutrient absorption by the crop. Plant analysis provides information on availability of nutrients to the plant including mineral nutrition. Mineral nutrition is classified in two subcategories: macroelements that include nitrogen, phosphorus, potassium, calcium, and magnesium and microelements or trace elements, including iron, boron, aluminum, fluoride, manganese, zinc, and copper. Table 12 summarizes mineral nutrition in the production of citrus fruit (Davidson, 1975).

Citrus crops require supplementary nitrogen because of leaching, volatilization losses, root uptake, and availability of organic materials of high carbon-nitrogen ratio, anaerobic conditions, and high phosphorus level. Nitrogen application and time rate are conditioned by characteristics of soil, tree, and climatic conditions. Phosphorus deficiency may occur by low total phosphorus supply, calcerous soils, competition by soil 
organisms for available phosphorus, excessive nitrogen fertilization, climatic factors, soil moisture deficit, etc. An excellent fixing power and slow rate of element movement in soils characterize phosphorous. To supply phosphorous deficiency, soluble forms of phosphorous have to be applied to crops (see Table 13). Phosphorus releases to surface water cause excessive growth of aquatic plants (eutrophication), which impacts aquatic systems by reducing dissolved oxygen levels during the night resulting in death of aquatic life (Thomann and Mueller 1987; Ciba-Geigy, 1975).

Potassium and magnesium impact the media in low levels. Magnesium deficiency is caused by leaching and is especially rapid as the soil acidity increases. Even though microelement deficiency is not an acute factor of ecological impacts, their excessive release could cause unexpected changes in living organisms (Labanaudkas et al. 1969; Wanielista et al., 1984).

Herbicides are defined as chemical substances designed to kill or inhibit the growth of plants, especially weed. Herbicides are well classified into four types: contact or herbicide designed to kill on contact by killing foliage; non-selective or herbicide that destroys or prevents all plant growth; post-emergence or herbicide designed to be applied before the crop emerges through the soil surface (see Table 14) (USEPA, 1990). 
Table 12. Mineral Nutrition in the Production of Citrus Fruit

(Information adapted from Ciba-Geigy, 1975).

\begin{tabular}{|c|c|c|c|c|c|}
\hline $\begin{array}{l}\text { Mineral } \\
\text { Nutrition }\end{array}$ & Element & Concept & $\begin{array}{c}\text { Plant Analysis Deficient } \\
\text { Range } \\
\text { (1) (Dry matter basis) }\end{array}$ & $\begin{array}{c}\text { Plant Analysis Excess } \\
\text { Range } \\
\text { (1) (Dry matter basis) }\end{array}$ & $\begin{array}{c}\text { Plant Analysis } \\
\text { Optimum Range (1) } \\
\text { (Dry matter basis) }\end{array}$ \\
\hline \multirow[b]{2}{*}{ Macroelements } & $\begin{array}{c}\text { Nitrogen } \\
(\mathrm{N})\end{array}$ & $\begin{array}{l}\text { Constituent of } \\
\text { proteins, } \\
\text { chloro-phyl, } \\
\text { and other } \\
\text { essential } \\
\text { components of } \\
\text { plants. }\end{array}$ & $\begin{array}{l}\%<2.2 \\
\text { Effects: Reduced yields and } \\
\text { tendency to smoother fruit. The } \\
\text { fruit is bland in flavor due to low } \\
\text { sugar and acid contents.; poorer } \\
\text { external and internal fruit color } \\
\text { and paler juice color; they also } \\
\text { present decay in storage. Retards } \\
\text { vegetative growth, causes } \\
\text { yellowing of foliage followed by } \\
\text { dieback of twigs. }\end{array}$ & $\begin{array}{l}\%>2.8 \\
\text { Effects: Can reduce yields, } \\
\text { fruits are smaller in size than } \\
\text { usual, more coarse texture, } \\
\text { and greener with high sugar } \\
\text { and acid level. Can impair } \\
\text { quality and may affect the } \\
\text { availability of } \mathrm{Cu}, \mathrm{Zn}, \mathrm{Mn} \text {, } \\
\text { Mo, } \mathrm{P} \text {, etc. }\end{array}$ & $\begin{array}{l}\% \quad 2.4 \text { to } 2.6 \\
\text { Effect: Optimum } \\
\text { productivity and growth. }\end{array}$ \\
\hline & $\begin{array}{l}\text { Phosphorus } \\
\text { (P) }\end{array}$ & $\begin{array}{l}\text { Involved in } \\
\text { energy transfer } \\
\text { reactions and in } \\
\text { nucleic acids. }\end{array}$ & $\begin{array}{l}\%<0.09 \\
\text { Effects: Thicker rinds and a } \\
\text { lower juice content. }\end{array}$ & $\begin{array}{l}\%>0.30 \\
\text { Effects: Yields reduction }\end{array}$ & $\begin{array}{l}\% \quad 0.12 \text { to } 0.16 \\
\text { Effects: Optimum } \\
\text { productivity and growth. }\end{array}$ \\
\hline
\end{tabular}


Table 12. Mineral Nutrition in the Production of Citrus Fruit (Cont.)

(Information adapted from Ciba-Geigy, 1975).

\begin{tabular}{|c|c|c|c|c|c|}
\hline $\begin{array}{c}\text { Mineral } \\
\text { Nutrition }\end{array}$ & Element & Concept & $\begin{array}{c}\text { Plant Analysis Deficient } \\
\text { Range } \\
\text { (1) (Dry matter basis) }\end{array}$ & $\begin{array}{c}\text { Plant Analysis Excess } \\
\text { Range } \\
\text { (1) (Dry matter basis) }\end{array}$ & $\begin{array}{c}\text { Plant Analysis } \\
\text { Optimum Range (1) } \\
\text { (Dry matter basis) }\end{array}$ \\
\hline & $\begin{array}{l}\text { Magnesium } \\
(\mathrm{Mg})\end{array}$ & $\begin{array}{l}\text { Constituent of } \\
\text { chlorophyll. }\end{array}$ & $\begin{array}{l}\%<0.16 \\
\text { Effects: Reduced yields and fruit } \\
\text { size. Yellow blotches on leaves. }\end{array}$ & $\begin{array}{l}\%>1.2 \\
\text { Effects: Yields reduction }\end{array}$ & $\begin{array}{l}\% \quad 0.26 \text { to } 0.6 \\
\text { Effects: Optimum } \\
\text { productivity and growth. }\end{array}$ \\
\hline \multirow{3}{*}{ Microelements } & $\begin{array}{l}\text { Zinc } \\
(\mathrm{Zn})\end{array}$ & $\begin{array}{l}\text { Nutritional } \\
\text { disorder in } \\
\text { citrus related to } \\
\text { fruit size and } \\
\text { shape. }\end{array}$ & $\begin{array}{l}\text { ppm }<21 \\
\text { Effects: Drastic reduction in } \\
\text { yield, tendency to smaller, and } \\
\text { misshapen fruit. Chlorotic leaf } \\
\text { spots, small leaves, die back of } \\
\text { twigs. }\end{array}$ & $\begin{array}{l}\text { ppm > } 300 \\
\text { Effects: N/A }\end{array}$ & $\begin{array}{l}\text { ppm } 25 \text { to } 100 \\
\text { Effects: Optimum } \\
\text { productivity and growth. }\end{array}$ \\
\hline & $\begin{array}{l}\text { Manganese } \\
(\mathrm{Mn})\end{array}$ & $\begin{array}{l}\text { Related to } \\
\text { irregularities in } \\
\text { leaves color. }\end{array}$ & $\begin{array}{l}\text { Ppm }<16 \\
\text { Effects: N/A }\end{array}$ & $\begin{array}{l}\text { ppm }>1000 \\
\text { Effects: N/A }\end{array}$ & $\begin{array}{l}\text { ppm } 25 \text { to } 200 \\
\text { Effects: Optimum } \\
\text { productivity and growth. }\end{array}$ \\
\hline & $\begin{array}{l}\text { Iron } \\
\qquad(\mathrm{Fe})\end{array}$ & $\begin{array}{l}\text { Chlorosis } \\
\text { pattern in leaves } \\
\text { that results from } \\
\text { low chlorophyl } \\
\text { content. }\end{array}$ & $\begin{array}{l}\text { Ppm }<36 \\
\text { Effects: Reduced fruit-set and } \\
\text { yield, tendency to smaller, } \\
\text { smoother fruit. }\end{array}$ & $\begin{array}{l}\text { ppm }>250 \\
\text { Effects: N/A }\end{array}$ & $\begin{array}{l}\text { ppm } 60 \text { to } 120 \\
\text { Effects: Optimum } \\
\text { productivity and growth. }\end{array}$ \\
\hline
\end{tabular}

(1): Concentration percentages and ppm are based on leaves composition from non fruiting terminals. 
Table 13. Impact of Excess of Fertilizers in the Environment

(Thomann and Muller, 1994).

\begin{tabular}{|l|l|l|l|}
\hline $\begin{array}{c}\text { Mineral Nutrition } \\
\text { Elements }\end{array}$ & \multicolumn{1}{|c|}{$\begin{array}{c}\text { Release Causes to the } \\
\text { Environment }\end{array}$} & \multicolumn{1}{c|}{ Environmental Impact } & Recommendations \\
\hline Nitrogen & $\begin{array}{l}\text { Associated with agricultural runoff by } \\
\text { leaching and volatilization losses. }\end{array}$ & $\begin{array}{l}\text { Stimulate the growth of algae } \\
\text { (eutrophication) and water weeds in } \\
\text { surface water. Blue-green algae are } \\
\text { able to fix nitrogen gas from the } \\
\text { atmosphere. }\end{array}$ & $\begin{array}{l}\text { Applications are conditioned by soil } \\
\text { characteristics, tree and climatic } \\
\text { conditions. }\end{array}$ \\
\hline Phosphorus & $\begin{array}{l}\text { Associated with agricultural fertilization } \\
\text { and surface runoff and effluent disposal, } \\
\text { mainly. }\end{array}$ & $\begin{array}{l}\text { Enhance the growth of algae and } \\
\text { plants depressing the dissolved } \\
\text { oxygen in aquatic systems. }\end{array}$ & $\begin{array}{l}\text { Soluble forms should be applied } \\
\text { such as superphosphate or } \\
\text { ammonium phosphate. }\end{array}$ \\
\hline Other Elements & Agricultural runoff. & $\begin{array}{l}\text { Inhibitory role in living organism. } \\
\text { according with the type of soil and } \\
\text { the crop need. }\end{array}$ \\
\hline
\end{tabular}

Table 14. Herbicides and Mode of Action

(Institute of Food and Agricultural Sciences, IFAS, 1985).

\begin{tabular}{|c|c|c|c|}
\hline \multirow{2}{*}{$\begin{array}{c}\text { Biological } \\
\text { (Mycoherbicide) }\end{array}$} & \multicolumn{2}{|c|}{ Foliar Applied } & Soil Applied \\
\hline & Systemic & Contact & Preemergence \\
\hline Phytophthora palmivora & Glyphosate & Paraquat & $\begin{array}{c}\text { Diuron } \\
\text { Terbicil } \\
\text { Bromacil } \\
\text { Trifluralin }\end{array}$ \\
\hline
\end{tabular}


Weed management control represents an important factor in citrus groves since they compete with trees for water, nutrients, and light-reducing yields. Florida citrus groves practice four methods of weed control: mowing, tillage or cultivation, chemical, and biological weed control. Mowing prevents soil erosion and is effective for tall growing weed species but not for low-growing pos-trate species, which also compete with trees for nutrients and water. Tillage destroys each new crop of weeds before it produces seeds. Weed cultivation has to be timed annually to sever the stems from the roots while the roots are young (Tucker, 1995).

Chemical weed control is widely practiced in Florida citrus crops. The action and fate of herbicides in the environment is critical because their misuse could result in poor weed control, tree damage, illegal residues in fruit, and soil accumulation. Biological weed control is relatively new in Florida but is offering positive results. This method uses insects, pathogens (Phytophthora palmivora, which has been developed into the microherbicide, DelVine), and viruses that attack weeds until they get consumed. Florida law is objecting this type of agricultural practices since the introduction of foreign species could attack other plants once their primary food is terminated (Tucker, 1995).

Since chemical weed control is one of the most widely used methods in Florida citrus groves, it is necessary to emphasize its principles. As with other crops, citrus groves apply selective chemical herbicides to control weeds. Some of them can be classified as highly selective and others as selective. Herbicide selectivity can not be 
considered absolute. However, selectivity depends on formulation dosage, method of application, and effect of local environment conditions, lack of uptake by tree roots, lack of transport of chemical to the site of toxic action, physiological tolerance of the tree to the chemical, and metabolism of the herbicide to non-toxic products (Dupont De Nemours and Co., 1983a).

Chemical weed control considers two types of herbicides, soil-applied and foliar. Soil environmental impacts, in the case of soil-applied herbicides, is related to fate and transport. At the same time, fate and transport are directly linked with solubility of the herbicide and capacity of soil to facilitate leaching. Persistence (see Table 15) and toxicity of soil active herbicides depend on physical, chemical, and microbiological processes in soils (Institute of Food and Agricultural Sciences, 1985).

Physical processes including volatility, leaching, and erosion due to water and wind are responsible for herbicide losses. Florida soil characteristics and climatic conditions including soil adsorption or repulsion, temperature, water movement, and air movement facilitate volatilization of herbicides which increases herbicidal releases to the atmosphere. Rainfall and/or irrigation in citrus groves determine leaching and runoff of herbicides (Institute of Food and Agricultural Sciences, 1985). 
Table 15. Relative Persistence of Herbicides in Soils

(Tucker and Singh, 1990).

\begin{tabular}{|l|l|l|}
\hline \multicolumn{1}{|c|}{$\begin{array}{c}\text { Non-Persistent } \\
\text { (Half life less than } 30 \\
\text { days) }\end{array}$} & $\begin{array}{c}\text { Moderately Persistent } \\
\text { (Half life greater than 30 days and } \\
\text { less than 100 days) }\end{array}$ & $\begin{array}{c}\text { Persistent } \\
\text { (Half life greater than 100 days) }\end{array}$ \\
\hline $\begin{array}{l}\text { Dalapon } \\
\text { 2,4-dichlorophenoxyacetic } \\
\text { Glyphosate }\end{array}$ & $\begin{array}{l}\text { Simazine } \\
\text { Terbicil }\end{array}$ & $\begin{array}{l}\text { Bromacil } \\
\text { Paraquat } \\
\text { Trifluralin } \\
\text { Diuron }\end{array}$ \\
\hline
\end{tabular}


Chemical processes include photochemical decomposition (sunlight deactivation) and adsorption (adhesion of molecules or ions to soil molecules). Adsorption not only reduces herbicide absorption (unavailability of substances to be taken up by plants and microorganisms) but also will generate desorption (release of substances), which is a critical factor that negatively impacts the environment. Microbiological processes produce poor weed control since the effect of the herbicide is reduced by microbial (bacteria, fungi, and actinomycetes) herbicide deactivation (Tucker and Singh, 1990).

Foliar herbicides, even though highly effective to control weeds, can concentrate in citrus trees, causing serious injuries to the trees. Their environmental impact is related to air contamination (volatilization of herbicides) and possible chemical residual accumulation (herbicides byproducts) in soil (Dupont De Nemours and Co. 1983b). Table 16 summarizes the herbicides registered for use on Florida citrus, including some of their agrochemical characteristics and possible environmental impacts. According to water solubility ranges reported, herbicide releases could impact the environment by soil adsorbtion, runoff with soil particles leaching, runoff, and bioaccumulation (Ney, 1995; Tucker, 1995; Ciba-Geigy, 1995). Pesticides can be classified as insecticides, acaricides, and fungicides. An insecticide is defined as a chemical substance used to kill insects. The major insecticide products used in the citrus groves are phosphorus ester bases. Some of the most used are parathion, malathion, methidathion, and diazinon (Dupuis, 1975). 
Table 16. Herbicides Registered for Use on Florida Citrus

(Ney, 1995; Tucker and Singh, 1990; Ciba-Geigy, 1975).

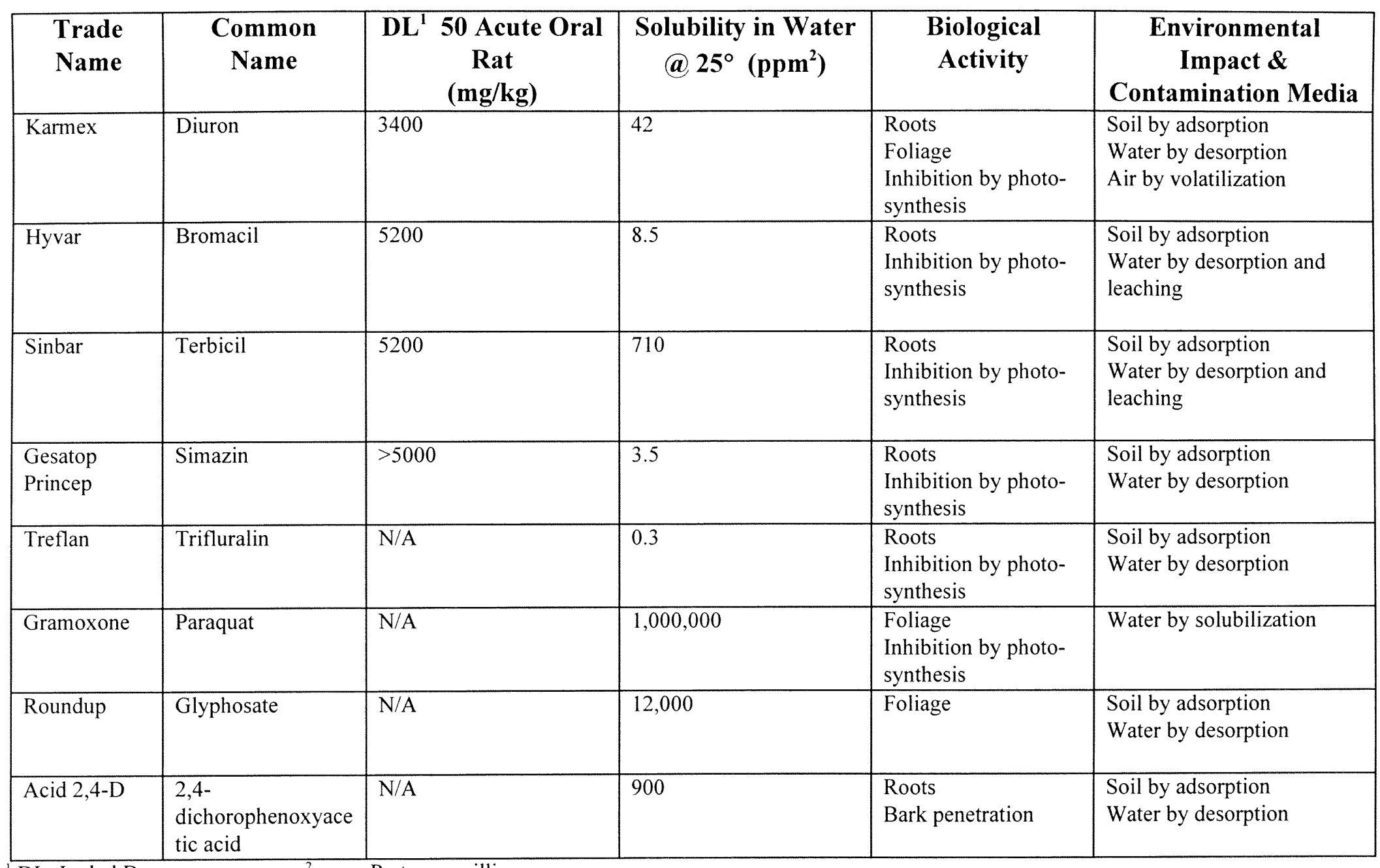

'DL: Lethal Doses

${ }^{2}$ ppm: Parts per million 
Table 17 summarizes some important agrochemical characteristics of these compounds. From their water accumulation values, these compounds are concluded to have medium water solubility. This determines that these compounds could adsorb in soil, run off with soil, and bioaccumulate. In some cases, bioaccumulation and food chain contamination could occur. Residues in fruit could be expected (Ney, 1995).

Acaricides are substances used to destroy mites. Two main compounds are widely used in Florida citrus: chlorobenzilate and bromopropylate (see Table 18). Chlorobenzilate and bromopropylate are considered practically insoluble in water. The environmental risk could be soil adsorption, accumulation, and bioaccumulation (Tucker and Singh, 1990).

Fungicides are defined as chemical substances used to control fungal diseases. The most common fungal diseases in Florida are scab (Elisonoe fawcetti), melanose (Diaporthe citri), and greasy spot (Mycospharella citri). Spraying fungicides on groves can control fungus disease. Some common fungicides used in Florida are diphenyl, ophenyl-phenol, thiabendazole, and benomyl. Refer to Table 19 for a summary of agrochemical characteristics of fungicides (Knapp, 1996). 
Table 17. Insecticides Most Used in Citrus and Agrochemical Properties (Adapted from Ney, 1995 and Fasulo and Knapp, 1995).

\begin{tabular}{|l|l|l|l|l|}
\hline Trade Name & \multicolumn{1}{|c|}{$\begin{array}{c}\text { Common } \\
\text { Name }\end{array}$} & $\begin{array}{c}\text { DL' 50 Acute } \\
\text { Oral Rat } \\
(\mathbf{m g} / \mathbf{k g})\end{array}$ & $\begin{array}{c}\text { Solubility in } \\
\text { Water } \mathbf{a} \mathbf{2 5}^{\circ} \mathbf{C} \\
\left(\mathbf{p p m}^{\mathbf{2}}\right)\end{array}$ & $\begin{array}{c}\text { Biological } \\
\text { Activity }\end{array}$ \\
\hline Folidol & Parathion & $\begin{array}{l}13 \text { (males) } \\
3.6 \text { (females) }\end{array}$ & 24 & $\begin{array}{l}\text { Non-systemic } \\
\text { Penetrative } \\
\text { Contact } \\
\text { Stomach }\end{array}$ \\
\hline Cythion & Malathion & 2800 & 145 & $\begin{array}{l}\text { Non-systemic } \\
\text { Contact } \\
\text { Stomach }\end{array}$ \\
\hline Supracide & Methidathion & $25-54$ & 240 & $\begin{array}{l}\text { Non-systemic } \\
\text { Penetrative } \\
\text { Contact } \\
\text { Stomach }\end{array}$ \\
\hline Basudin & & & & $\begin{array}{l}\text { Non-systemic } \\
\text { Penetrative } \\
\text { Contact } \\
\text { Stomach }\end{array}$ \\
\hline
\end{tabular}

DL: Lethal Doses

${ }^{2}$ ppm: Parts per million

Table 18. Agrochemical Properties of Most Common Acaricides in Citrus (Adapted from Dupuis, 1975).

\begin{tabular}{|l|l|l|l|l|}
\hline Trade Name & \multicolumn{1}{|c|}{$\begin{array}{c}\text { Common } \\
\text { Name }\end{array}$} & $\begin{array}{c}\text { DL } \mathbf{5 0} \text { Acute } \\
\text { Oral Rat } \\
(\mathbf{m g} / \mathbf{k g})\end{array}$ & $\begin{array}{c}\text { Solubility In } \\
\text { Water } \mathbf{9} \mathbf{2 5}^{\circ} \mathbf{C} \\
\left(\mathbf{p p m}^{\mathbf{2}} \mathbf{)}\right.\end{array}$ & $\begin{array}{c}\text { Biological } \\
\text { Activity }\end{array}$ \\
\hline Akar & Chlorobenzilate & $700-3100$ & $\begin{array}{l}\text { Practically } \\
\text { insoluble }\end{array}$ & $\begin{array}{l}\text { Non-systemic } \\
\text { Contact }\end{array}$ \\
\hline Neoron & Bromopropylate & $>500$ & $<5$ & $\begin{array}{l}\text { Non-systemic } \\
\text { Contact }\end{array}$ \\
\hline
\end{tabular}

${ }^{1}$ DL: Lethal Doses

${ }^{2} \mathrm{ppm}$ : Parts per million 


\section{Table 19. Fungicides Registered for Use in Florida Citrus Crops}

(Adapted from Ney, 1995).

\begin{tabular}{|l|l|l|l|l|}
\hline Trade Name & \multicolumn{1}{|c|}{$\begin{array}{c}\text { Common } \\
\text { Name }\end{array}$} & $\begin{array}{c}\text { Solubility in } \\
\text { Water a } \\
\mathbf{2 5}^{\circ} \mathbf{C}\left(\mathbf{p p m}^{\mathbf{1})}\right.\end{array}$ & $\begin{array}{l}\text { Fungistatic Action } \\
\text { and Characteristics }\end{array}$ & $\begin{array}{l}\text { Environmental } \\
\text { Impact }\end{array}$ \\
\hline Biphenyl & Diphenyl & 7.5 & $\begin{array}{l}\text { Provide vapor around } \\
\text { the fruit. Volatile } \\
\text { aromatic compound. }\end{array}$ & $\begin{array}{l}\text { Could adsorb to } \\
\text { soil, run-off with } \\
\text { soil, and } \\
\text { bioaccumulate. }\end{array}$ \\
\hline $\begin{array}{l}\text { Orto- } \\
\text { phenylphenol }\end{array}$ & o-phenyl-phenol & & $\begin{array}{l}\text { Post-harvest fungistatic. } \\
\text { Used for soaking or } \\
\text { flooding citrus fruits. }\end{array}$ & $\begin{array}{l}\text { Accumulate at } \\
\text { points where the } \\
\text { rind is ruptured. } \\
\text { Could leach run- } \\
\text { off, and } \\
\text { bioaccumulate. }\end{array}$ \\
\hline $\begin{array}{l}\text { 2-4-thiazolyl- } \\
\text { benzimidazole }\end{array}$ & Thiabendazole & $<50$ & $\begin{array}{l}\text { Applied in dip or spray, } \\
\text { alone or in combination } \\
\text { with waxes. }\end{array}$ & $\begin{array}{l}\text { Could leach, run- } \\
\text { off, adsorption, } \\
\text { biodegradation, } \\
\text { and } \\
\text { bioaccumualtion. }\end{array}$ \\
\hline $\begin{array}{l}\text { 1- } \\
\text { butylcarbamoyl } \\
-2- \\
\text { benzimidazole }\end{array}$ & Benomyl & & $\begin{array}{l}\text { Applied in dip or spray, } \\
\text { alone or in combination } \\
\text { with waxes. }\end{array}$ & $\begin{array}{l}\text { Could leach, run- } \\
\text { off, adsorption, } \\
\text { biodegradation, } \\
\text { and } \\
\text { bioaccumualtion. }\end{array}$ \\
\hline
\end{tabular}

${ }^{1}$ ppm: Parts per million 
Fungus can contaminate citrus fruits before harvesting or after harvesting. Before harvesting, the pathogens remain in a latent stage until the fruit reaches maturity, and then they develop rapidly. Post-harvest diseases may occur during picking and handling operations due to fruit injuries. In this case, airborne spores of the pathogen contaminate the fruit at the site while it is being prepared for marketing. During transport and storage, the fungus develop rapidly causing great losses of fruit. A regular fungus control in storage rooms is to fumigate with nitrogen trichloride or sulfur dioxide (Dupuis, 1975).

Since a large area of Florida is citrus agricultural land, Florida Citrus Pest Management follows very closely the use of pesticides in the state. Therefore, the state has its own registered pesticides to apply in citrus crops. Table 20 summarizes restricted pesticides registered for use on Florida citrus. Table 21 summarizes nonrestricted pesticides for use on Florida citrus (Dupuis, 1975).

\subsubsection{Agriculture and prevention-of-pollution aspects}

The USEPA recommends some general but key rules to conduct a successful prevention-of-pollution program. The most fundamental rule is stopping pollution before it starts. This approach will result in economic benefits and protection to the environment. New prevention-of-pollution innovative programs must be designed as long-term strategies. If there is an existing pollution problem, solutions must be found and applied to minimize impacts on ecosystems (USEPA, 1996). 
Table 20. Restricted Pesticides Registered for Use on Florida Citrus

(Adapted from University of Florida, 1995).




Table 20. Restricted Pesticides Registered for Use on Florida Citrus (Cont.)

(Adapted from University of Florida, 1995).

\begin{tabular}{|c|c|c|c|c|c|c|}
\hline $\begin{array}{l}\text { Trade } \\
\text { Name }\end{array}$ & $\begin{array}{c}\text { Common } \\
\text { Name } \\
\end{array}$ & Environmental Impact & $\begin{array}{c}\text { EPA Registration } \\
\text { Number }\end{array}$ & $\begin{array}{c}\text { Tolerance } \\
\text { Fruit (ppm) }\end{array}$ & $\begin{array}{l}\text { Days to } \\
\text { Harvest }\end{array}$ & $\begin{array}{c}\text { Rel } \\
\text { Hours }\end{array}$ \\
\hline $\begin{array}{l}\text { Metasystox } \\
-R\end{array}$ & $\begin{array}{l}\text { Oxydemeton- } \\
\text { methyl }\end{array}$ & $\begin{array}{l}\text { Toxic to fish, mammals, and aquatic } \\
\text { organisms. Highly toxic to honey bees. } \\
\text { Warning: Limit to } 2 \text { applications per } \\
\text { season. Certified applicator must be } \\
\text { physically present during mixing, loading, } \\
\text { and equipment cleaning and repair. A } \\
\text { certification license is required to purchase } \\
\text { and apply. Will kill bees for } 24 \text { hours } \\
\text { following application. }\end{array}$ & $3125-111$ & 1 & 7 & 12 \\
\hline Micromite & Diflubenzuron & $\begin{array}{l}\text { Toxic to aquatic invertebrates. } \\
\text { Warning: Certified applicator must be } \\
\text { physically present during mixing, loading, } \\
\text { and equipment cleaning and repair. }\end{array}$ & $37100-21-400$ & 0.05 & 21 & 24 \\
\hline Nemacur & Fenamiphos & $\begin{array}{l}\text { Toxic to fish, mammals, and aquatic } \\
\text { organisms. } \\
\text { Warning: Certified applicator must be } \\
\text { physically present during mixing, loading, } \\
\text { and equipment cleaning and repair. } \\
\text { Liquid formulation only. Limited to } 2 \\
\text { applications per season with 14-day } \\
\text { interval. }\end{array}$ & $3125-283$ & 0.6 & $\begin{array}{l}\text { Grapefruit } \\
\& \\
\text { oranges- } \\
30 \\
\text { Lemon \& } \\
\text { lime-180 }\end{array}$ & 12 \\
\hline Supracide & Methidathion & $\begin{array}{l}\text { Toxic to fish, mammals, and aquatic } \\
\text { organisms. Highly toxic to honey bees. } \\
\text { Warning: Only } 2 \text { applications per season } \\
\text { at least } 45 \text { days apart. One application per } \\
\text { season to lemons if mixed with oil. A } \\
\text { certification license is required to purchase } \\
\text { and apply. }\end{array}$ & $100-501$ & $\begin{array}{l}\text { Mandarin-6 } \\
\text { Others-2 }\end{array}$ & $14-60$ & 24 \\
\hline
\end{tabular}


Table 20. Restricted Pesticides Registered for Use on Florida Citrus (Cont.)

(Adapted from University of Florida, 1995).

\begin{tabular}{|c|c|c|c|c|c|c|}
\hline $\begin{array}{l}\text { Trade } \\
\text { Name }\end{array}$ & $\begin{array}{l}\text { Common } \\
\text { Name }\end{array}$ & Environmental Impact & $\begin{array}{c}\text { EPA Registration } \\
\text { Number }\end{array}$ & $\begin{array}{c}\text { Tolerance } \\
\text { Fruit }(\mathbf{p p m})\end{array}$ & $\begin{array}{l}\text { Days to } \\
\text { Harvest }\end{array}$ & $\begin{array}{c}\text { Rel } \\
\text { Hours }\end{array}$ \\
\hline Talsar & Bifenthrin & $\begin{array}{l}\text { Toxic to fish, mammals, and aquatic } \\
\text { organisms. Highly toxic to honey bees. } \\
\text { Warning: A certification license is } \\
\text { required to purchase \& apply. }\end{array}$ & $279-3130$ & Nonbearing & 12 months & 24 \\
\hline Temik & Aldicarb & $\begin{array}{l}\text { Warning: Notification of intent to apply is } \\
\text { required. Apply between January } 1 \text { and } \\
\text { April } 30 \text {. See label for best management } \\
\text { practices based on soil type. }\end{array}$ & $264-417$ & 0.3 & $\begin{array}{l}\text { Lemon-30 } \\
\text { Others-0 }\end{array}$ & 48 \\
\hline
\end{tabular}

${ }^{1}$ ppm: Parts per million 
Table 21. Non-Restricted Pesticides for Use on Florida Citrus

(Adapted from Knapp, 1996).

\begin{tabular}{|c|c|c|c|c|c|c|}
\hline $\begin{array}{l}\text { Trade } \\
\text { Name }\end{array}$ & $\begin{array}{l}\text { Common } \\
\text { Name }\end{array}$ & Environmental Impact & $\begin{array}{c}\text { EPA Registration } \\
\text { Number }\end{array}$ & $\begin{array}{c}\text { Tolerance Fruit } \\
\left(\mathrm{ppm}^{1}\right)\end{array}$ & $\begin{array}{l}\text { Days to } \\
\text { Harvest }\end{array}$ & $\begin{array}{c}\text { Rel } \\
\text { Hours }\end{array}$ \\
\hline Admire & Imidacloprid & $\begin{array}{l}\text { Toxic to aquatic invertebrates. Highly } \\
\text { toxic to honey bees. } \\
\text { Warning: Limit to } 32 \text { oz/acre/year. Will } \\
\text { kill bees for } 24 \text { hours following } \\
\text { application. }\end{array}$ & 3125-SLN & In study & In study & In study \\
\hline Aliette & Fosetyl Al & $\begin{array}{l}\text { Warning: Do not exceed } 4 \text { applications } \\
\text { per season. }\end{array}$ & $264-516$ & 0.5 & 30 & 12 \\
\hline Align & Azadirachtin & Toxic to fish and aquatic organisms. & $62552-1$ & Exempt & 0 & 12 \\
\hline $\begin{array}{l}\text { Azinphos } \\
\text {-Methyl }\end{array}$ & $\begin{array}{l}\text { Azinphos- } \\
\text { methyl salts }\end{array}$ & $\begin{array}{l}\text { Limit } 2 \text { app/season. Highly toxic to honey } \\
\text { bees. } \\
\text { Warning: Liquid formulation only. A } \\
\text { certification license is required to purchase } \\
\text { and apply. Will kill bees for } 24 \text { hours } \\
\text { following application. }\end{array}$ & (2EC) $51036-76$ & 2 & $\begin{array}{l}1 \text { app-7 } \\
2 \text { app-28 }\end{array}$ & 48 \\
\hline Carzol & $\begin{array}{l}\text { Formetanate } \\
\text { hydrochloride }\end{array}$ & $\begin{array}{l}\text { Toxic to honey bees. } \\
\text { Warning: Do not apply more than } 5 \mathrm{lb} \\
\text { during a } 12 \text { month period. Will kill bees } \\
\text { for } 24 \text { hours following application. }\end{array}$ & $45639-74$ & 4 & 7 & 48 \\
\hline Comite & Propargite & $\begin{array}{l}\text { Warning: } \\
\text { year. }\end{array}$ & $400-104$ & 5 & 21 & 48 \\
\hline Cygon & Dimethoate & $\begin{array}{l}\text { Highly toxic to honey bees } \\
\text { Warning: A certification license is } \\
\text { required to purchase \& apply. }\end{array}$ & $5905-250$ & 2 & $\begin{array}{l}15 \text { or } 45 \\
\text { depending } \\
\text { on rate }\end{array}$ & 12 \\
\hline
\end{tabular}


Table 21. Non-Restricted Pesticides for Use on Florida Citrus (Cont.)

(Adapted from Knapp, 1996).

\begin{tabular}{|c|c|c|c|c|c|c|}
\hline $\begin{array}{l}\text { Trade } \\
\text { Name }\end{array}$ & $\begin{array}{l}\text { Common } \\
\text { Name }\end{array}$ & Environmental Impact & $\begin{array}{c}\text { EPA Registration } \\
\text { Number }\end{array}$ & $\begin{array}{c}\text { Tolerance Fruit } \\
\left(\mathrm{ppm}^{1}\right)\end{array}$ & $\begin{array}{l}\text { Days to } \\
\text { Harvest }\end{array}$ & $\begin{array}{c}\text { Rel } \\
\text { Hours }\end{array}$ \\
\hline Cythion & Malathion & $\begin{array}{l}\text { Highly toxic to honey bees. } \\
\text { Warning: A certification license is } \\
\text { required to purchase and apply. }\end{array}$ & 5905-196-38167 & 8 & 7 & 12 \\
\hline Dimethoate & Dimethoate & $\begin{array}{l}\text { Highly toxic to honey bees. } \\
\text { Warning: A certification license is } \\
\text { required to purchase and apply. }\end{array}$ & $5905-493-38167$ & 2 & $\begin{array}{l}15 \text { or } 45 \\
\text { depending } \\
\text { on rate }\end{array}$ & 12 \\
\hline Eclipse & Fenoxycarb & Toxic to fish and aquatic organisms. & $100-750$ & Nonbearing & 12 months & 12 \\
\hline Ethion & Ethion & $\begin{array}{l}\text { Warning: Grapefruit, oranges and hybrids } \\
\text { - } 90 \text { days between applications. Hybrids - } \\
\text { Limit to } 2 \text { applications per season. Lemon } \\
\text { and limes - Limit to } 1 \text { application per } \\
\text { season. }\end{array}$ & $279-1254$ & 2 & $\begin{array}{l}\text { Lemonade } \\
\text { Lime- } 21 \\
\text { Others-0 }\end{array}$ & 48 \\
\hline Hyvar X & Bromacil & $\begin{array}{l}\text { Toxic to fish and aquatic organisms. } \\
\text { Warning: A certification license is } \\
\text { required to purchase and apply. }\end{array}$ & $325-287$ & 0.1 & 0 & 12 \\
\hline
\end{tabular}

${ }^{1}$ ppm: Parts per million 
Environmental pollution in agricultural activities primarily comes from non-point sources or diffuse indirect sources. Thus, released pesticides may reach points, as controlled by critical factors, with resultant damage to ecosystems. Factors include pesticide molecule mobility through bonding to soil particles and its solubility in water. This relation is defined by partition coefficients. Another factor is the potential of pesticides to decompose by sunlight, soil, microorganisms, chemical reactions, moisture, etc. (Knapp, 1996).

A successful tool to minimize pesticide releases is optimizing pesticide application methods. One common practice is to apply levels of pesticides exceeding those necessary to effectively control pests. However, this practice does increase the risk of pesticide releases to any or all environmental compartments. The most acute danger while applying pesticides is the misuse of pesticides including over-application, application during high wind or rain, improper disposal of unused material and canisters, etc. (Knapp, 1996).

\subsubsection{Irrigation}

Irrigation is a vital activity in agriculture as part of the operation flowchart diagram that can not be disregarded in citrus groves. Irrigation is a determinant for tree growth in citrus crops. Citrus trees need high irrigation of the root system to develop a vigorous tree, avoid excessive fruit dropping, get the maximum yield possible, and reach 
the highest quality and quantity of fruit. The yearly rainfall need for citrus trees is approximately $1,200 \mathrm{~mm}$ well distributed throughout the year. In Florida, rainfall quantity is enough but unpredictable, so a planned irrigation system is also necessary (Tucker, 1995).

There are basically two types of irrigation: gravity flow and pressure flow. Gravitational irrigation is further classified into flooding (border method), basin flooding, and furrow irrigation. Flooding irrigation is applying water until almost the entire growing area is wet. Basin flooding applies water to irrigate groups of 1-5 trees each. Furrow irrigation just wets the rows where the citrus tree is growing (Ciba-Geigy, 1975).

Pressure irrigation uses the sprinkling method. There are three types of pressure irrigation: portable, semi-portable, and stationary. They depend on the ability to move irrigation pipes from one place to another. Drip irrigation has been developed lately. This system applies water to the ground by using emitters located adjacent to each tree. Citrus crops need to be fertilized by irrigation methods. The process uses water pressure that injects nutrients close to the roots, using external power sources such as pumps. Fertilizer in the citrus industry was discussed extensively in the above pages (Becker et al., 1992). 


\subsubsection{Behavior of pesticides in soil, water, and air}

The behavior of pesticides in one or multiple media should consider that Florida, the area of study, has a subtropical climate that helps all organisms, including insects, weeds, and pests, to grow and develop easily. Soil characteristics in Florida enable pesticides to leach faster and easier. Three important media compartments are considered for this study to analyze pesticide release risks in ecosystems, soil, water, and air. Pesticides access the soil environment via runoff, infiltration, and leaching after periodic applications. Soil contamination may occur by spills, fallout from air, or substances directly or indirectly applied into soil. Some possible reactions could occur in soil after contamination of pesticides including hydrolysis, dissociation, sorption, biodegradation, and photolisis (Rao and Hornsby, 1991).

Pesticide persistence is also a function of soil depths; higher concentrations at lower depths increase the risk of contaminating environments. Solubility plays an important role since it determines the extent of adsorption on soils; in fact, the higher the solubility, and the less sorption. Sorption is simply given by the partition coefficient or Koc factor (Rao and Hornsby, 1991). The partition coefficient is defined as "the ratio of pesticide concentration in the sorbed-phase (bound to soil particles) and the solution phase (dissolved in the soil particles) or ratio of the amount of chemical adsorbed per unit weight of organic carbon (oc)." Accordingly, the smaller the Koc value, the greater the pesticide concentration in solution (see Table 22) (Rao and Hornsby, 1991). 
Table 22. Adsorption Coefficient for Selected Pesticides Used in Florida Citrus Groves

(Hornsby and Beckers, 1991; Ney, 1995).

\begin{tabular}{|c|c|c|c|c|c|c|c|c|c|c|}
\hline \multirow[t]{2}{*}{$\begin{array}{l}\text { Common } \\
\text { Name }\end{array}$} & \multicolumn{2}{|c|}{$\begin{array}{l}\text { Application } \\
\text { Type }\end{array}$} & \multirow{2}{*}{$\begin{array}{l}\text { Sorption } \\
\text { Coefficient } \\
\text { Koc1) }\end{array}$} & \multicolumn{2}{|c|}{$\begin{array}{l}\text { Relative } \\
\text { Losses }\end{array}$} & \multirow{2}{*}{$\begin{array}{l}\text { Octanol Water } \\
\text { Partition } \\
\text { Coefficient } \\
\text { Kow } 4)\end{array}$} & \multirow{2}{*}{$\begin{array}{c}\text { Water } \\
\text { Solubility } \\
\text { WS } \\
\left(\text { ppm }^{5}\right)\end{array}$} & \multirow{2}{*}{$\begin{array}{l}\text { Thin Layer } \\
\text { Chromato- } \\
\text { Graphy } \\
\text { Soil TLC- } \\
\text { Rf6) }\end{array}$} & \multicolumn{2}{|c|}{ Toxicity } \\
\hline & Soil & Foliar & & RLPI $^{2)}$ & $\mathrm{RRPI}^{3)}$ & & & & $\begin{array}{c}\left.\text { HALEQ }^{7}\right) \\
(\mathrm{ppb})\end{array}$ & $\begin{array}{l}\mathrm{LC50}^{8)} \\
(\mathrm{ppm})\end{array}$ \\
\hline \multicolumn{11}{|c|}{ HERBICIDES } \\
\hline Acid 2,4-D & $x$ & & 20 & N/A & N/A & 6 & 502,000 & 0.96 & 70 & 30 \\
\hline Bromacil & $\mathrm{x}$ & $\mathrm{x}$ & 72 & 5 & 5 & N/A & 8.5 & 0.69 & 2 & 15 \\
\hline Diuron & $\mathrm{x}$ & & 400 & 53 & 23 & 94 & 42 & 0.24 & 90 & 1 \\
\hline Glyphosate & & $\mathrm{x}$ & 2,640 & $>2,000$ & 1 & N/A & 12,000 & N/A & 28 & 2.8 \\
\hline Paraquat & & $\mathrm{x}$ & 15,473 & $>2,000$ & 1 & N/A & $1,000,000$ & 0 to 0.13 & 10 & 90 \\
\hline Simazine & $x$ & $\mathrm{x}$ & 135 & 22 & 128 & 155 & 135 & 0.45 & 4.9 & 42.6 \\
\hline Terbicil & $\mathrm{x}$ & & 55 & 5 & 5 & Soluble in water & $\begin{array}{l}0.071 \mathrm{~g} / 100 \\
\mathrm{ml} @ 25^{\circ} \mathrm{C}\end{array}$ & $\begin{array}{l}\text { Mobil in soil } \\
\text { because of the } \\
\text { low adsorption }\end{array}$ & 700 & 5 \\
\hline Trifluralin & $\mathrm{x}$ & & 8,000 & 1,330 & 2 & $\mathrm{~N} / \mathrm{A}$ & $\begin{array}{l}1 \mathrm{E}-4 \mathrm{~g} / 100 \\
\mathrm{ml} @ 27^{\circ} \mathrm{C}\end{array}$ & 0 & 8.3 & 0.014 \\
\hline \multicolumn{11}{|c|}{ INSECTICIDES } \\
\hline Diazinon & & $\mathrm{x}$ & 1,000 & 250 & 25 & N/A & 40 & $\mathrm{~N} / \mathrm{A}$ & 0.6 & 0.09 \\
\hline Malathion & & $x$ & 1,800 & $>2,000$ & 556 & 780 & 145 & $\mathrm{~N} / \mathrm{A}$ & 200 & 0.2 \\
\hline Methidathion & & $\mathrm{x}$ & 400 & 571 & 357 & N/A & $\mathrm{N} / \mathrm{A}$ & N/A & 7 & 0.01 \\
\hline Parathion & & $x$ & 4,800 & $>2,000$ & 14 & 6,400 & 24 & $\mathrm{~N} / \mathrm{A}$ & 2 & 1.43 \\
\hline
\end{tabular}


Table 22. Adsorption Coefficient for Selected Pesticides Used in Florida Citrus Groves (Cont.)

( Hornsby and Beckers, 1991; Ney, 1995)

\begin{tabular}{|c|c|c|c|c|c|c|c|c|c|c|}
\hline \multirow[t]{2}{*}{$\begin{array}{l}\text { Common } \\
\text { Name }\end{array}$} & \multicolumn{2}{|c|}{$\begin{array}{l}\text { Application } \\
\text { Type }\end{array}$} & \multirow{2}{*}{$\begin{array}{l}\text { Sorption } \\
\text { Coefficient } \\
\text { Koc } 1)\end{array}$} & \multicolumn{2}{|c|}{$\begin{array}{l}\text { Relative } \\
\text { Losses }\end{array}$} & \multirow{2}{*}{$\begin{array}{l}\text { Octanol Water } \\
\text { Partition } \\
\text { Coefficient } \\
\quad \text { Kow } 4)\end{array}$} & \multirow{2}{*}{$\begin{array}{c}\text { Water } \\
\text { Solubility } \\
\text { WS } \\
\left.\left(p^{5}\right)^{5}\right)\end{array}$} & \multirow{2}{*}{$\begin{array}{l}\text { Thin Layer } \\
\text { Chromato- } \\
\text { Graphy } \\
\text { Soil TLC-Rf6) }\end{array}$} & \multicolumn{2}{|c|}{ Toxicity } \\
\hline & Soil & Foliar & & RLPI $^{2)}$ & RRPI $^{3)}$ & & & & $\begin{array}{c}\text { HALEQ }^{7)} \\
\left(\mathrm{ppb}^{5)}\right)\end{array}$ & $\begin{array}{l}\operatorname{LC50}^{8)} \\
(\mathrm{ppm})\end{array}$ \\
\hline \multicolumn{11}{|c|}{ FUNGICIDES } \\
\hline Benomyl & & $\mathrm{x}$ & 1,900 & 79 & 2 & N/A & $\mathrm{N} / \mathrm{A}$ & $\mathrm{N} / \mathrm{A}$ & 400 & 0.17 \\
\hline Captan & & $\mathrm{x}$ & 224 & 800 & 800 & 785 & 104 & N/A & 900 & 0.0732 \\
\hline Diphenyl & $x$ & & N/A & N/A & N/A & 7,540 & 7.5 & N/A & N/A & N/A \\
\hline \multirow[t]{2}{*}{ Thiabendazole } & & $\mathrm{x}$ & 1,720 & N/A & N/A & 2,104 & $<50$ & $\mathrm{~N} / \mathrm{A}$ & $\mathrm{N} / \mathrm{A}$ & $\mathrm{N} / \mathrm{A}$ \\
\hline & $x$ & & & & & & & & & \\
\hline \multicolumn{11}{|c|}{ NEMATICIDES } \\
\hline Aldicarb & \multicolumn{2}{|c|}{ Incorporated } & 0.073 & 10 & 10 & 11.02 & 7,800 & $\mathrm{~N} / \mathrm{A}$ & 10 & 0.56 \\
\hline Fenamiphos & $x$ & & 100 & 20 & 20 & $\mathrm{~N} / \mathrm{A}$ & N/A & N/A & 2 & 0.11 \\
\hline
\end{tabular}

1) Koc: Sorption Coefficient. Koc of $>10,000$ will adsorb to soil organic carbon; Koc of 1,000 to 10,000 could behave either way; and Koc of 1,000 will not adsorb to soil organic carbon.

2) RLPI: Relative Leaching Potential Index. Smaller number indicates greater leaching hazard.

3) RRPI: Relative Runoff Potential Index. Smaller number indicates greater runoff hazard.

4) Kow: Octanol Water Partition Coefficient. Kow of $<500$ indicates high water solubility, mobility, little to no bioaccumulate or accumulate, degrated by microbes, plants, and animals. Kow of $>1,000$ indicates low water solubility, inmobility, nonbiodegradability, bioaccumulative, accumulative, persistent, and sorbed in soil. Kow of 500 to 1,000 indicates that the chemical can go the way of either low or high Kow.

5) ppm: parts per million ppb: parts per billion

6) WS: Water Solubility. Similar behavior ranges of Kow.

7) TLC-Rf: Thin Layer Chromatography. Gives a measure of the movement through soil. TLC-Rf $>0.75$, will not be adsorbed in soil and will be mobile (leach). TLC-Rf from 0.34 to 0.75 could go either way. TLC- $\mathrm{Rf}<0.34$, will be adsorbed and should not leach with water.

8) HAL or HALEQ: Life Time Health Advisory Level or Life Time Health Advisory Level Equivalent.

9) LC50: Aquatic Toxicity.

10) X: Applied to soil surface or foliage.

11) N/A: Data not available. 
Managing pesticides for crop production requires the most appropriate pesticide selection and application according to soil properties including soil mobility and toxicity in water to human and aquatic species. Pesticide mobility should occur via volatilization, runoff, leaching, or plant and animal uptake resulting in food-chain contamination. Pesticide parameters are critical in defining their fate in the environment. Some of them are Koc value, half-life $t_{1 / 2}$, the lifetime health advisory level equivalent (HALEQ-risk of drinking water), and the lethal concentrations $\left(\mathrm{LC}_{50}\right)$ aquatic toxicity or ability of the pesticides to cause $50 \%$ mortality in aquatic test species, etc. (Hornsby and Beckers, 1991).

Water contamination may occur by fallout of pesticides from air, spills, and unintentionall application of pesticides into water, runoff, and/or leaching. Pesticide residuals present diverse forms of reaction in water, depending on type of streams (rivers, lakes, ponds, groundwater, ocean, etc.), such as dissociation, hydrolysis, phototransformation, biodegradation, or sorption to particulate matter. Pesticide mobility is via volatilization, water movement, evaporation, irrigation with well water, or animals (Ney, 1995).

USEPA defines water solubility (WS) as the maximum possible concentration of a chemical compound dissolved in water. Therefore, if a pesticide is water-soluble, it can very readily disperse through the environment (USEPA, 1992b). 
Water solubility ranges (low, medium, and high) determine the fate and transport of pesticides. Low solubility is less than $10 \mathrm{ppm}$, medium solubility between 10 and $1,000 \mathrm{ppm}$, and high solubility greater than $1,000 \mathrm{ppm}$. Table 22 includes specific WS values of pesticides used in Florida citrus groves (Kenaga and Goring, 1980).

Octanol water partition coefficient (Kow) is another indicator of water contamination potential. Kow is an indicator of bioaccumulation or bioconcentration in the fatty tissue of living organisms. It also relates to water solubility, mobility, and sorption. The higher the Kow is, the greater the affinity of the chemical to bioaccumulate or bioconcentrate in the food chain, the greater its potential for sorption in soil, the lower its mobility, and the lower its solubility in water. Refer to Table 22 for range values of Kow of pesticides used in Florida citrus groves (Ney, 1981).

Air contamination may occur when a volatile chemical or airborne particulate matter (dust) containing a chemical gets into air as a result of a spill, evaporation, or any other release. Some of the reactions that may occur are phototransformation of the chemical in air, or it can be sorbed to particulate matter and be biodegraded, dissociated, hydrolyzed, or phototransformed. Pesticide mobility could occur through air by air or precipitation, or it can move as fallout with precipitation or with particulate matter to contaminate other environmental compartments. Aerial fumigation of pesticides also contributes to contamination of the air compartment, soil compartment, and water compartment. Aerial fumigation increases the extent of contamination beyond the area of 
fumigation, miles away of it, because of the wind transport or pesticide mobility factor. Factors such as target distance, airplane and wind speed are factors that control pesticide drift. Airplane speed recommended to spray fungicides for citrus crops is $90-120 \mathrm{mph}$, which is about half the speed for chemical applications on other crops (Langham and McGrail, 1987).

This study also acknowledges impacts on plants and animals, which are impacted by pesticide releases. Plant contamination in the citrus groves results from pesticide applications directly or indirectly to soils, irrigation, and fertilizing practices. Common reactions in this medium are metabolism, hydrolysis, dissociation, photolysis on the citrus tree surface, and sorption (Helling and Turner, 1968).

Mobility of pesticide releases in this compartment occurs by release into the air, into the soil via the root system, into the fruit ending in processed products. Pesticides may reach the animal compartment by direct or indirect releases during pest management applications or by drinking water, breathing, or eating citrus byproducts with pesticide residues. The main reactions, which may occur in animals, are metabolism, hydrolysis, dissociation, bioaccumulation, and phototransformation. Plant and animal media are focuses of interest in the citrus industry because the use of pesticides will result in metabolism reactions (Helling and Turner, 1968). 


\subsubsection{Phase II}

\subsubsection{Harvesting}

The Florida citrus industry practices three types of harvesting: hand, mechanical, and chemical. Hand harvesting is the most popular operation in Florida. The high quality fresh citrus market requires hand harvesting to ensure peel cosmetic standards. During hand harvesting, fresh fruit is detached by workers and placed into bags of $60-90 \mathrm{lb}$ and then separated for marketing as is or for cannery processing (see Photographs 1-2) (Hume, 1999).

Mechanical harvesting is basically a combination of pulling, twisting, and snapping motions similar to the movements that workers perform in hand-picking (see Photograph 3). Mass removal machines apply external shaking force onto the trunk or major limbs, which is transmitted to the fruit through the minor limbs or foliage. An abscission chemical is necessary for satisfactory performance. The fruit is shaken onto the ground and picked up later. Mechanical harvesting causes more harm than hand harvesting by increased trash, attached stems, and mechanical damage in the form of splits and internal injury (Florida Citrus Mutual, 1999). The most considerable damage caused to the fruit in this operation occurs when the fruit impacts the ground or the catching frames. Fruit dropped on the ground must go to cannery plants, and it must be processed within 36 hours. Fruit losses can be reduced by removing trash and loosening the soil as fast as possible (Townsend, 1999). 


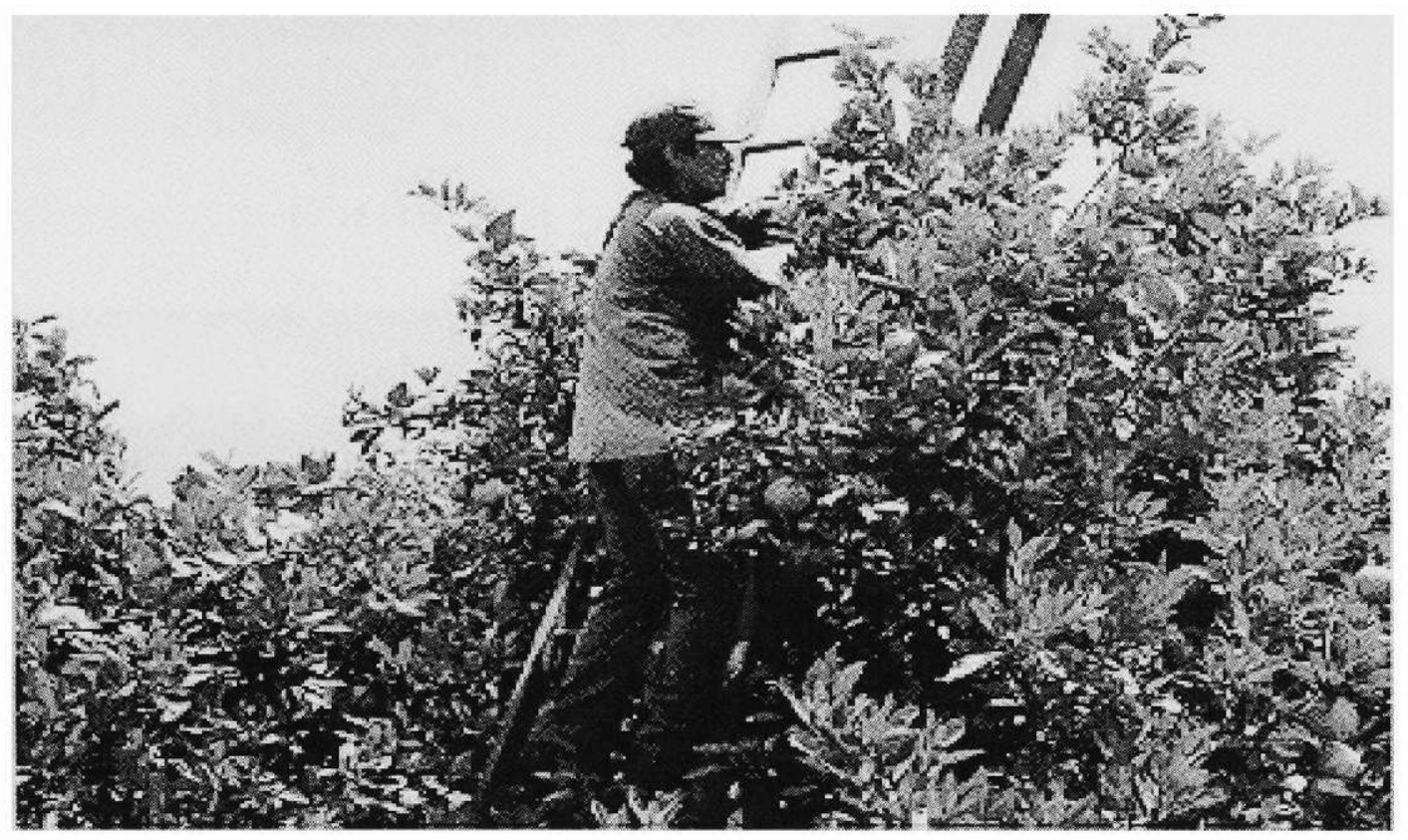

Photograph 1. Manual Fruit Harvesting

(Townsend, 1999).

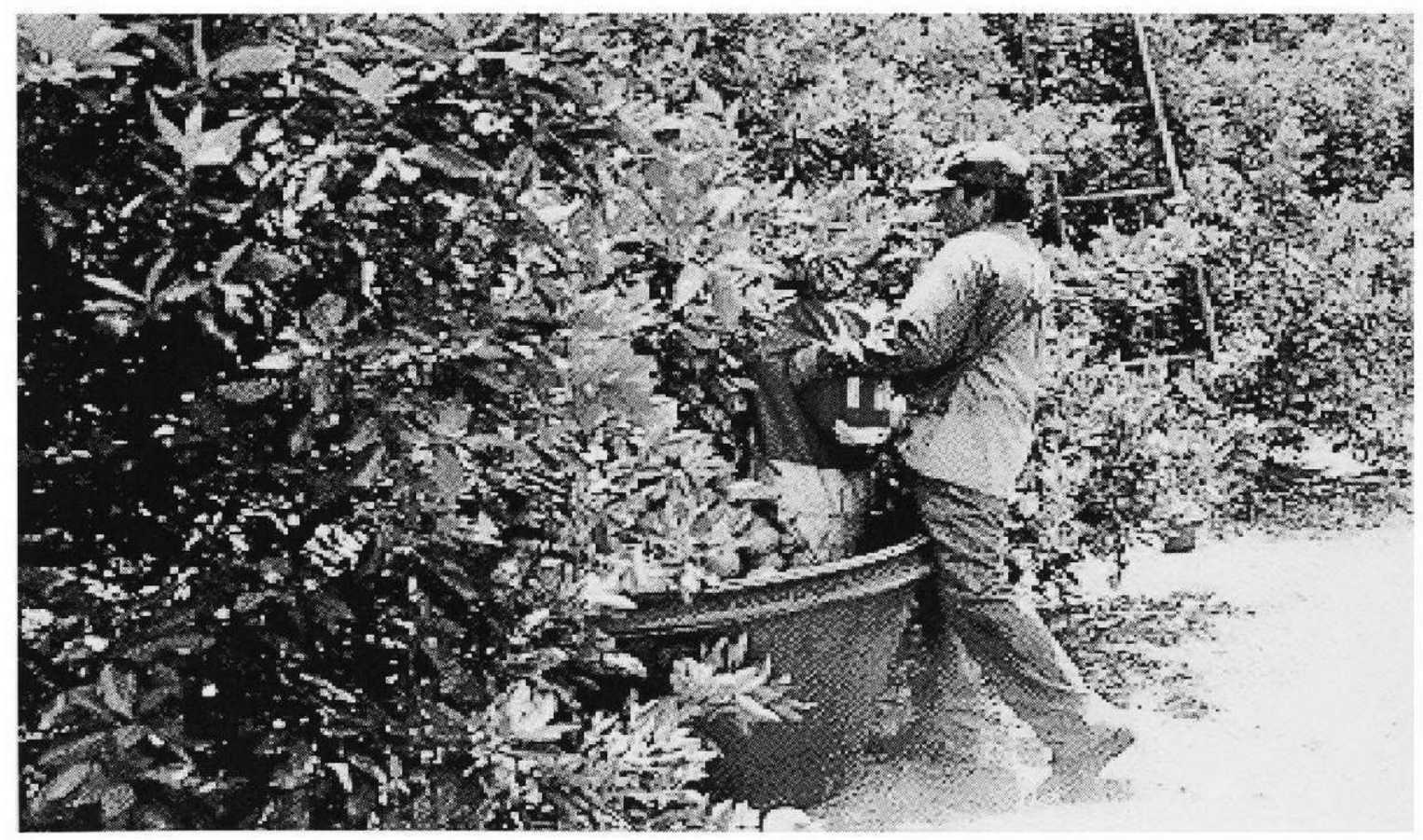

Photograph 2. Dumping Citrus Bag into a Tub

(Townsend, 1999). 


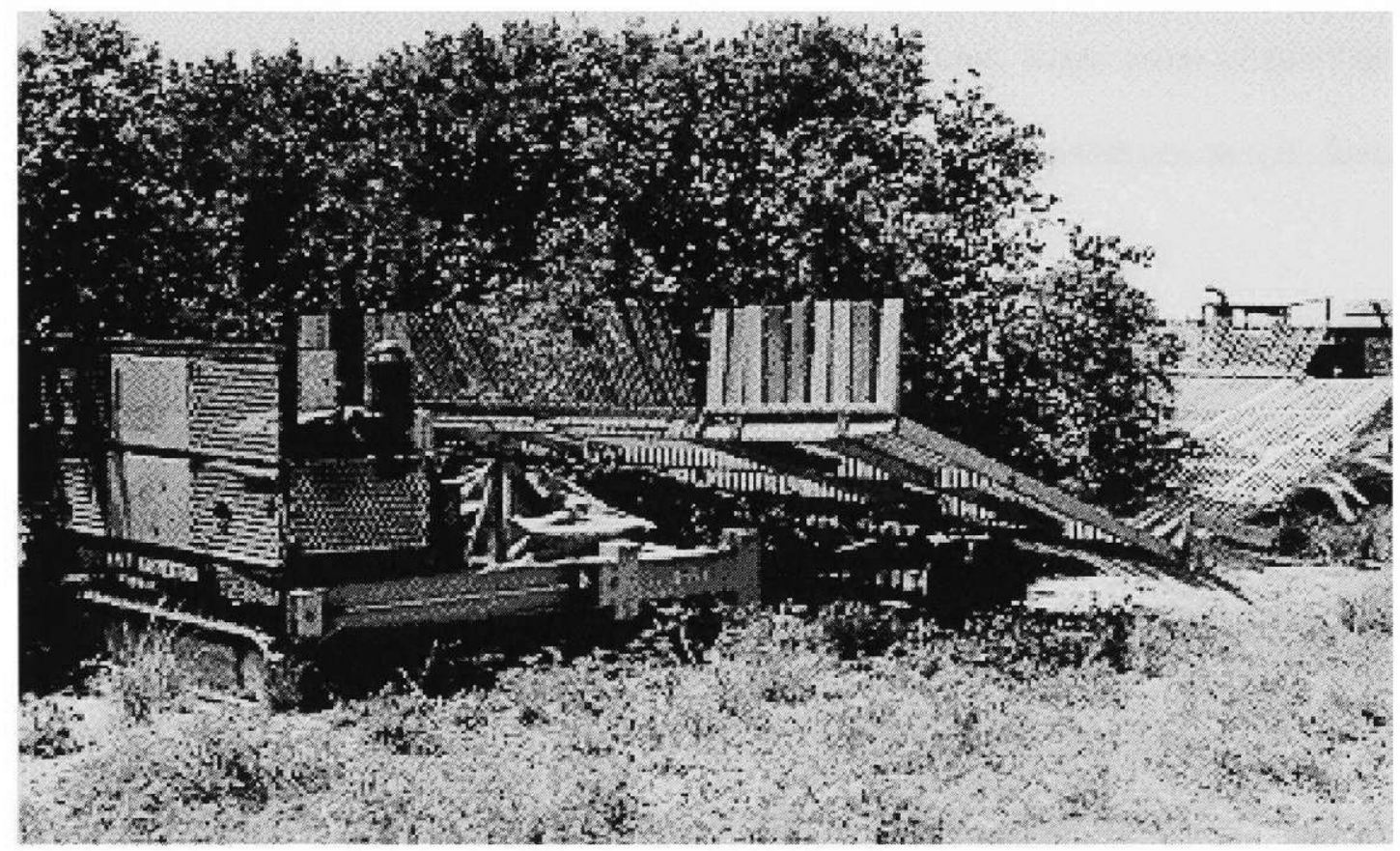

Photograph 3. Mechanical Fruit Harvesting

(Townsend, 1999). 
Chemical harvesting is done by applying abscission chemicals that loosen the citrus fruit naturally, facilitating pickers' hand harvesting and mechanical harvesting. Some common chemicals used to spray citrus trees to ensure fruit abscission are ethylene, cycloheimide, ethrel, and glyixime (experimental). This operation is recommended for processed fruit harvesting since chemicals cause peel injuries. Since most of the Florida orange crops are processed, peel injury is not important unless it produces severe damage such as fruit rot problems (Wills et al., 1981).

\subsubsection{Detaching Fruit, Handling, and Collection}

Fruit collection methods depend on whether the fruit is for processing or for the fresh fruit market. Two methods can be used to accomplish this operation: catching frames or rake-pickup machines. Catching frames are rectangular padded areas used as collectors or containers between citrus trees and ground to catch fruit harvested by mechanical harvesters as shown in Photograph 3. Rake-pickup systems collect fruit from the ground by using rotatory brushes that group the fruit between trees as long fruit rows to make the collection easy (Townsend, 1999). After collection, producers create special conditions to limit decay and prolong product life and quality. For example, in the case of fresh fruit, fungicides or biphenyl-treated pads are packed with the product to diminish fruit decay. Fruit is stored at a cool $32-34{ }^{\circ} \mathrm{F}$ in Florida. The process of packing is done using full telescoping fiberboard boxes containing standard weights of 18,20 , and $39 \mathrm{~kg}$ of oranges and $4.5 \mathrm{~kg}$ of limes (McGregor, 1987). 


\subsubsection{Phase III}

\subsubsection{Transport}

Fruit is transported via highways using van trucks and piggyback trailers. Loading is done by hand or using pallets. After fruits are harvested either by hand or mechanical harvesting, pickers dump the fruit into plastic tubs with approximately 900 pounds of capacity (see Photograph 4). A special truck (goat) goes into the grove and picks up the tub with hydraulic booms. The tub is emptied in a special frame located in the back of the goat. The goat goes outside of the trees to download the fruit into large open tractor-trailers (see Photographs 5 to 7). Truck-trailer capacity is approximately 45,000 pounds of citrus. The truck-tractor carries the fruit to the packaging house or to the processing plant (Townsend, 1999).

\subsubsection{Phase IV - XIV}

\subsubsection{Canning plants}

Before harvesting, the citrus grower makes a decision whether the fruit will be processed as juice and byproducts or packed as fresh product. This section discusses aspects related to canning plants. The next section discusses all aspects related to packaging houses. Most fruit used for canning plants is trucked directly from the grove to the processing plant (Townsend, 1999). 


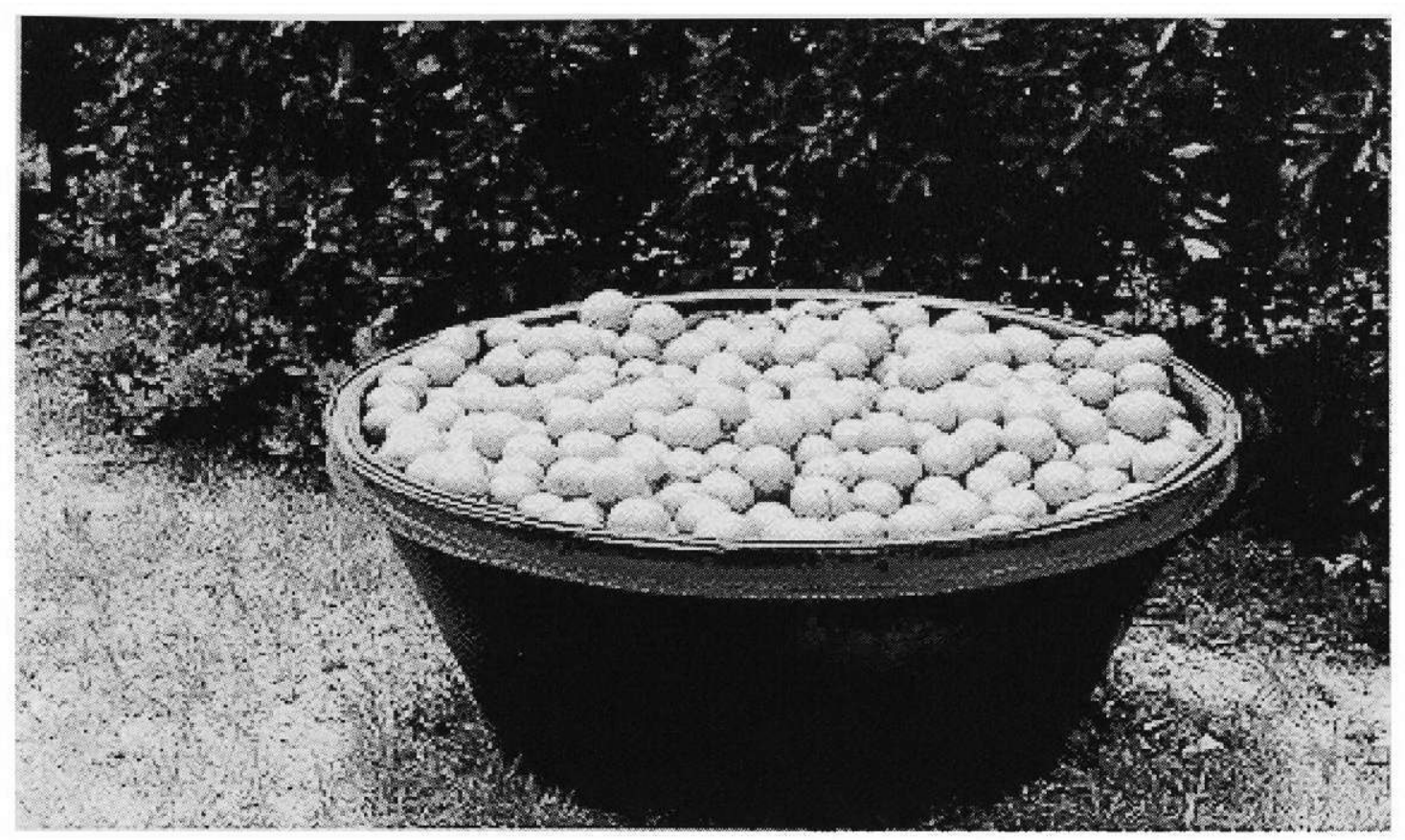

Photograph 4. Tub Full of Oranges

(Townsend, 1999).

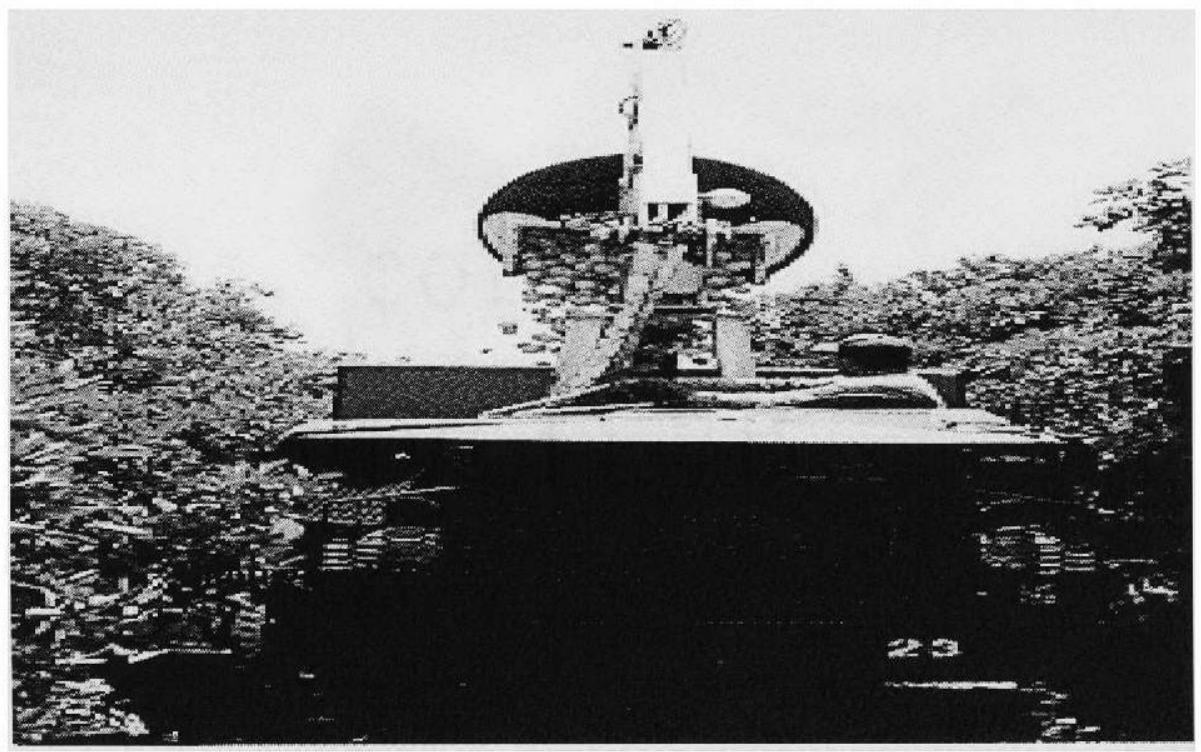

Photograph 5. Goat Picking up the Tub

(Townsend, 1999). 


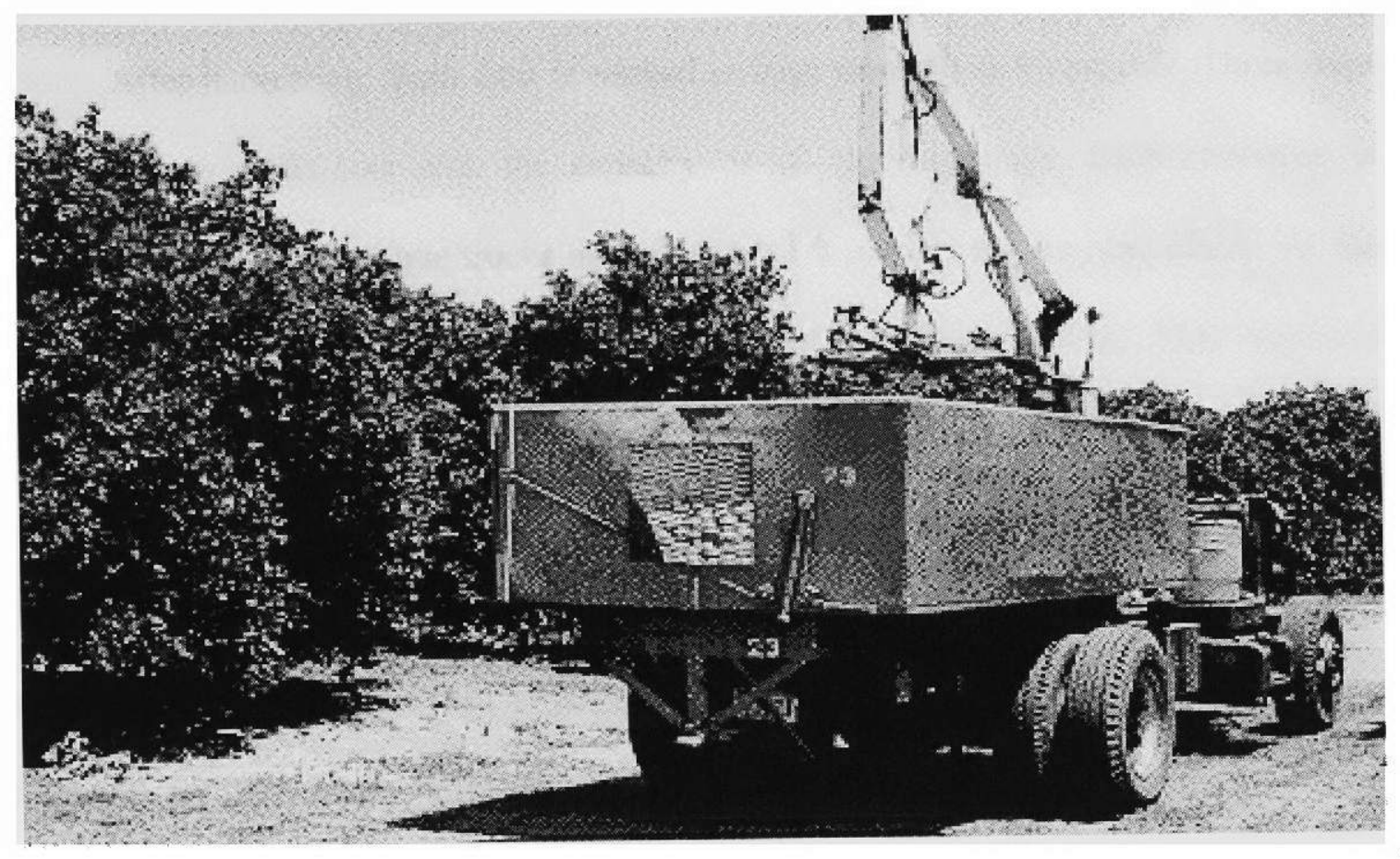

Photograph 6. Goat Loaded with Fruit

(Townsend, 1999).

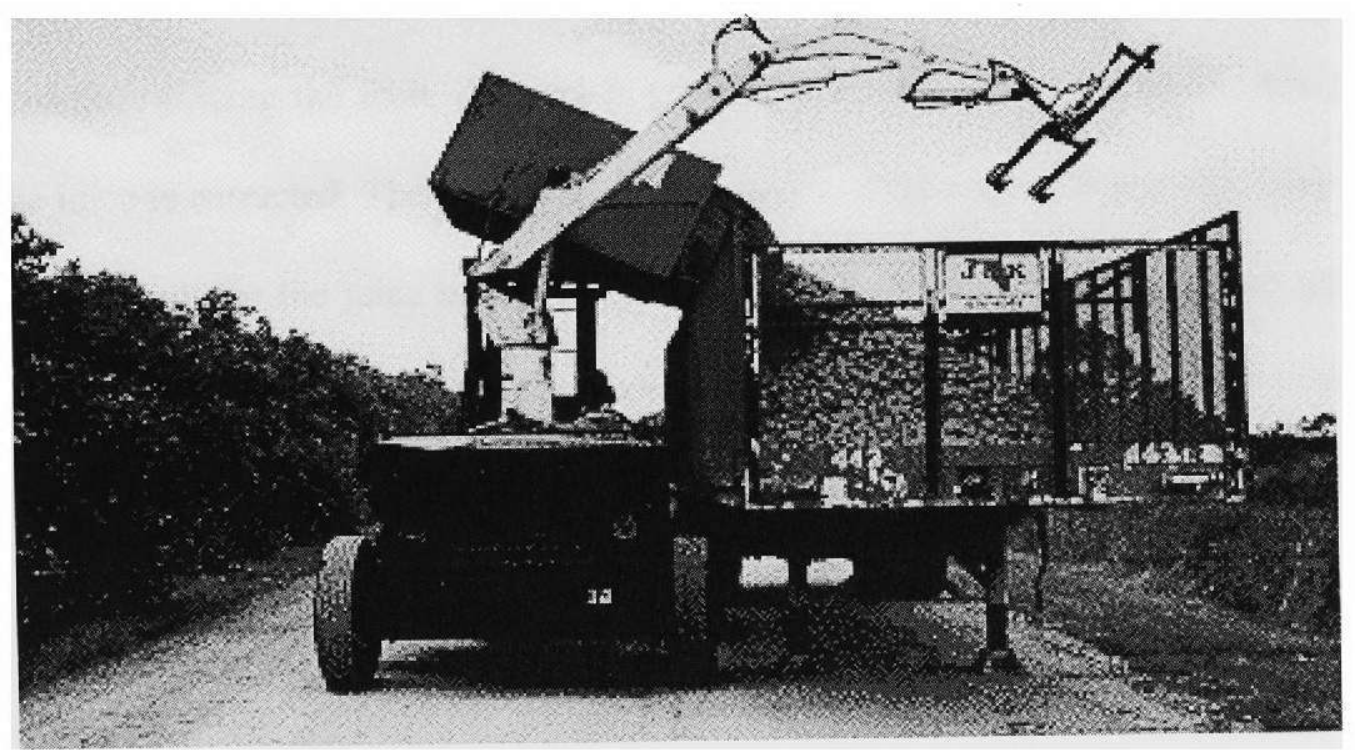

Photograph 7. Goat Dumping Fruit into a Trailer

(Townsend, 1999). 
After harvesting, fresh fruit is packed in bags from 60 to 90 pounds. These bags are placed in containers with the capacity of 10 standard bags. Each container is transported on adapted grove trucks or trailers until it reaches the canning plants. At the processing plant, the trailer with oranges is weighed (see Photograph 8). This weight is used to pay growers for the quantity of fruit to be processed (Townsend, 1999).

Once the fruit reaches the plant, it is unloaded, inspected, and temporarily placed in storage bins for no more than 24 hours in order to prevent and reduce mold growth and microbial contamination. From the holding bins, the fruit is transported by conveyors through a washing process; then, it is graded for bad or damaged fruit. Now, the fruit is separated by size and sent to the juice extractors (see Photographs 9 to 12) (Kesterson and Braddock, 1975).

Before juicing the fruit, the peel is pricked to extract the oils found in the peel; then the juice is extracted. The pulp juice is screened to remove pulp and seeds. This step is very important for the juice industry because it prevents microorganisms from getting into the juice at the time of extraction, which would lower the quality of the product. From this point on, the production of byproducts starts (Kesterson and Braddock, 1975). 


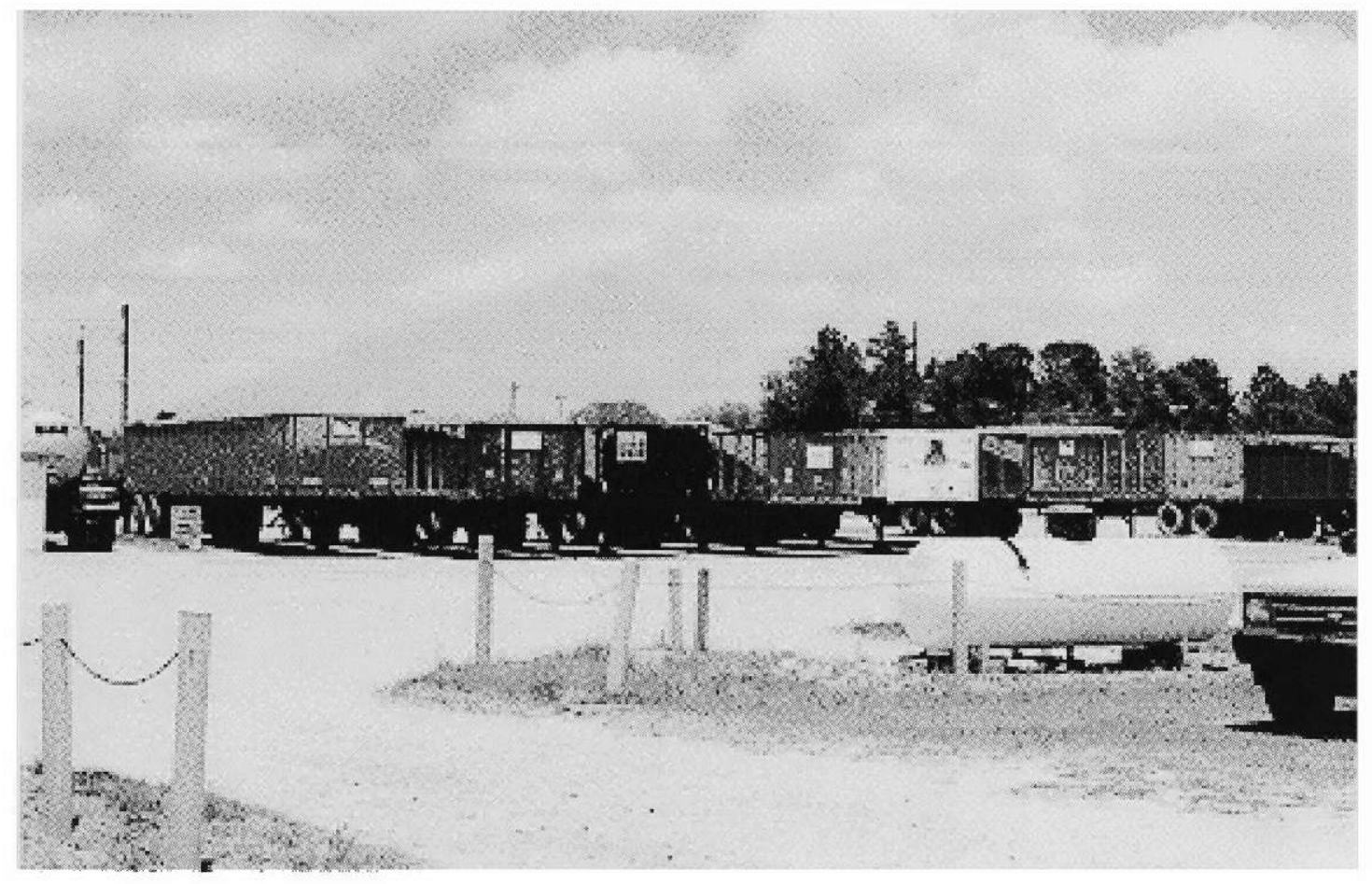

Photograph 8. Trailers at a Processing Plant

(Townsend, 1999).

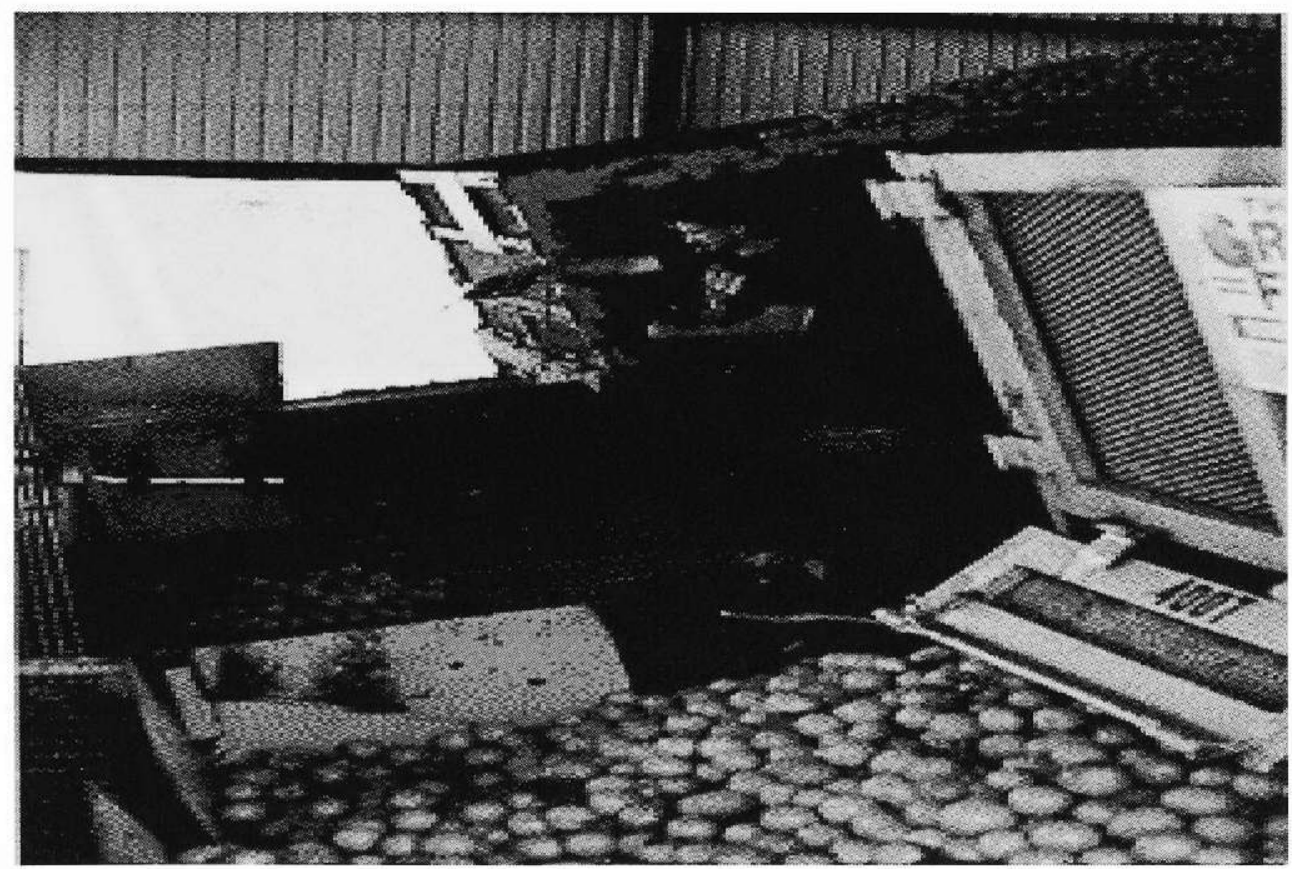

Photograph 9. Fruit Unloading

(Townsend, 1999). 


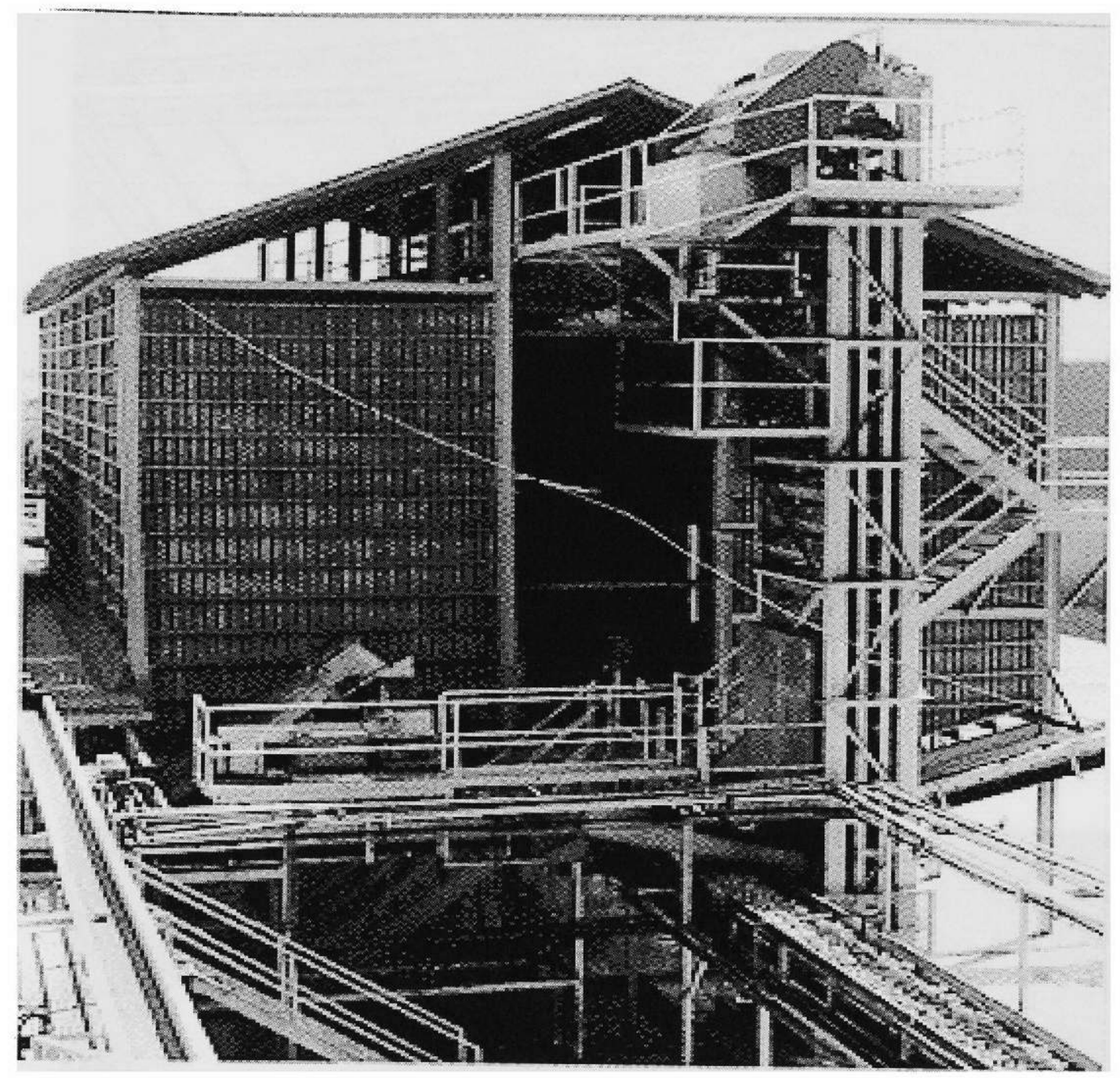

Photograph 10. Fruit Storage Bins

(Townsend, 1999). 


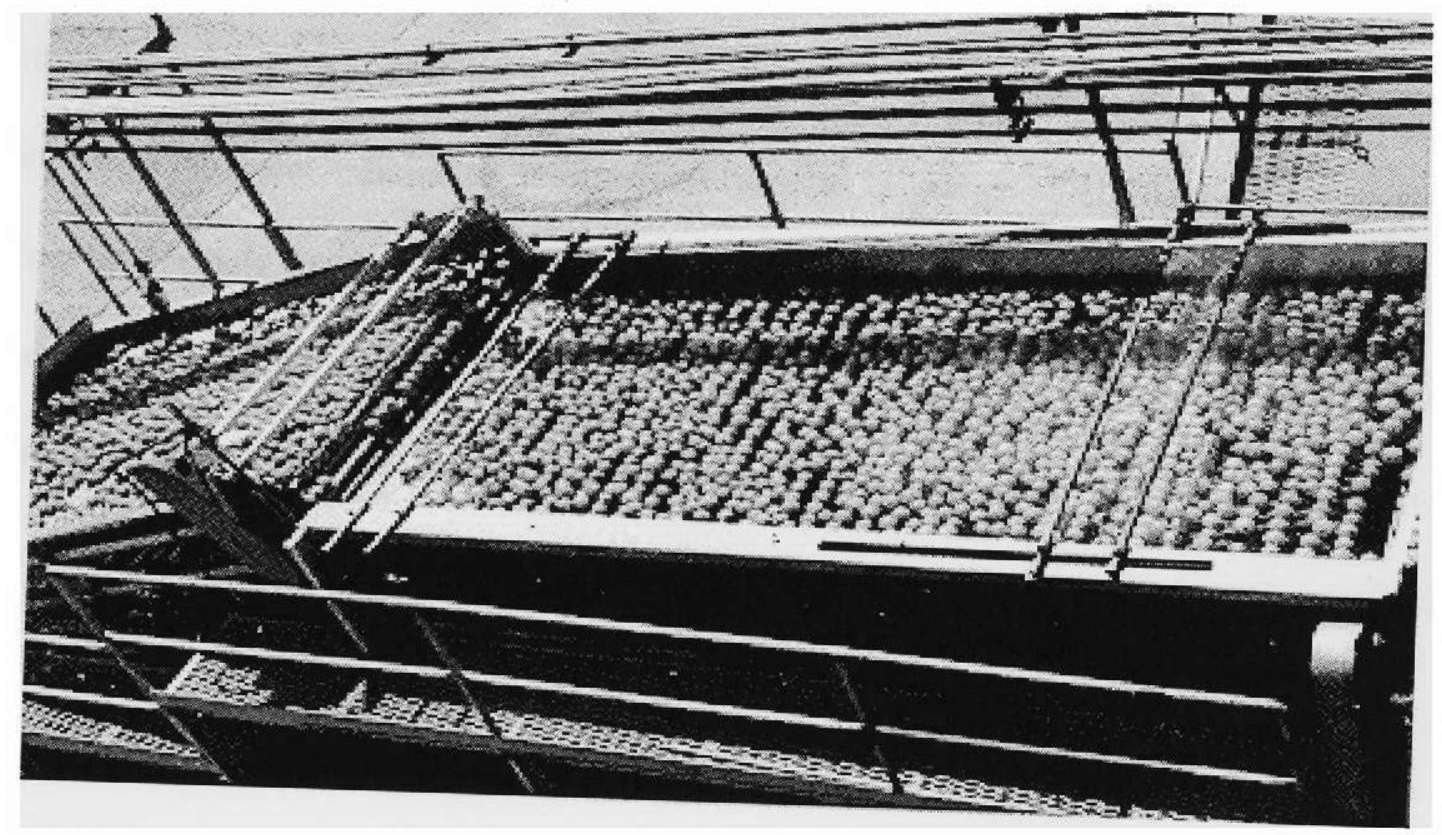

Photograph 11. Washing Process

(Townsend, 1999).

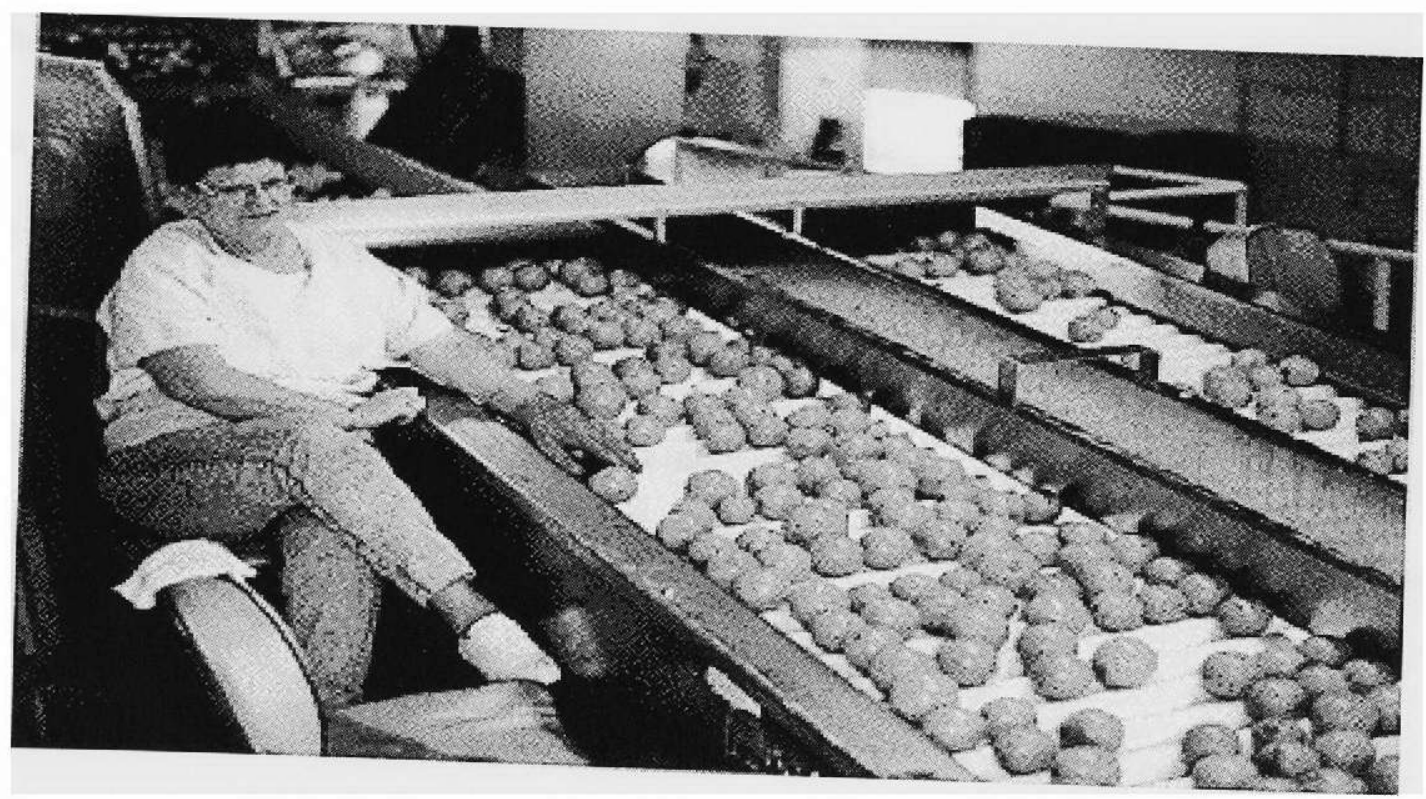

Photograph 12. Grading Process

(Townsend, 1999). 
During the juice extraction process, diverse types of products and byproducts are produced. The main products are citrus juices that later will become concentrates. The extracted juice is finished by extraction of excessive amounts of pulp. This pulp is composed of juice vesicles or sacs, which have to be removed and then processed into other byproducts for the beverage and food industries. Once the juice is finished, it goes to evaporation tanks where a certain amount of juice is concentrated and chilled for future manufacturing processes and the rest is treated to produce commercial orange juice (see Photographs 13 to 16 ). The concentrated product is quick-frozen after canning and then stored at $-10^{\circ} \mathrm{F}$ until marketed (Berk, 1969).

Essential oils are extracted from oil sacs or vesicles located in the outer rind or flavedo of the fruit. The flavor is used in the beverage, perfume, and flavor industries. The most suitable citrus fruits used to extract oil are orange, grapefruit, tangerine, temple, tangelo, murcott, lemon, and lime. The oil is obtained by applying pressure or rasping the oil sacs. The oil is washed away with water to form an emulsion and finally an insoluble solid ( 1 to $3 \%$ oil). The oil extracted is fed to a desludger to produce an oil-rich emulsion (70 to $80 \%$ oil). The oil-rich emulsion is fed directly to a polishing centrifuge to produce clear oil. Following separation, the oil is blended and dewaxed in stainless steel tanks (see Photograph 17) (Ciba-Geigy, 1975 and Townsend, 1999). 


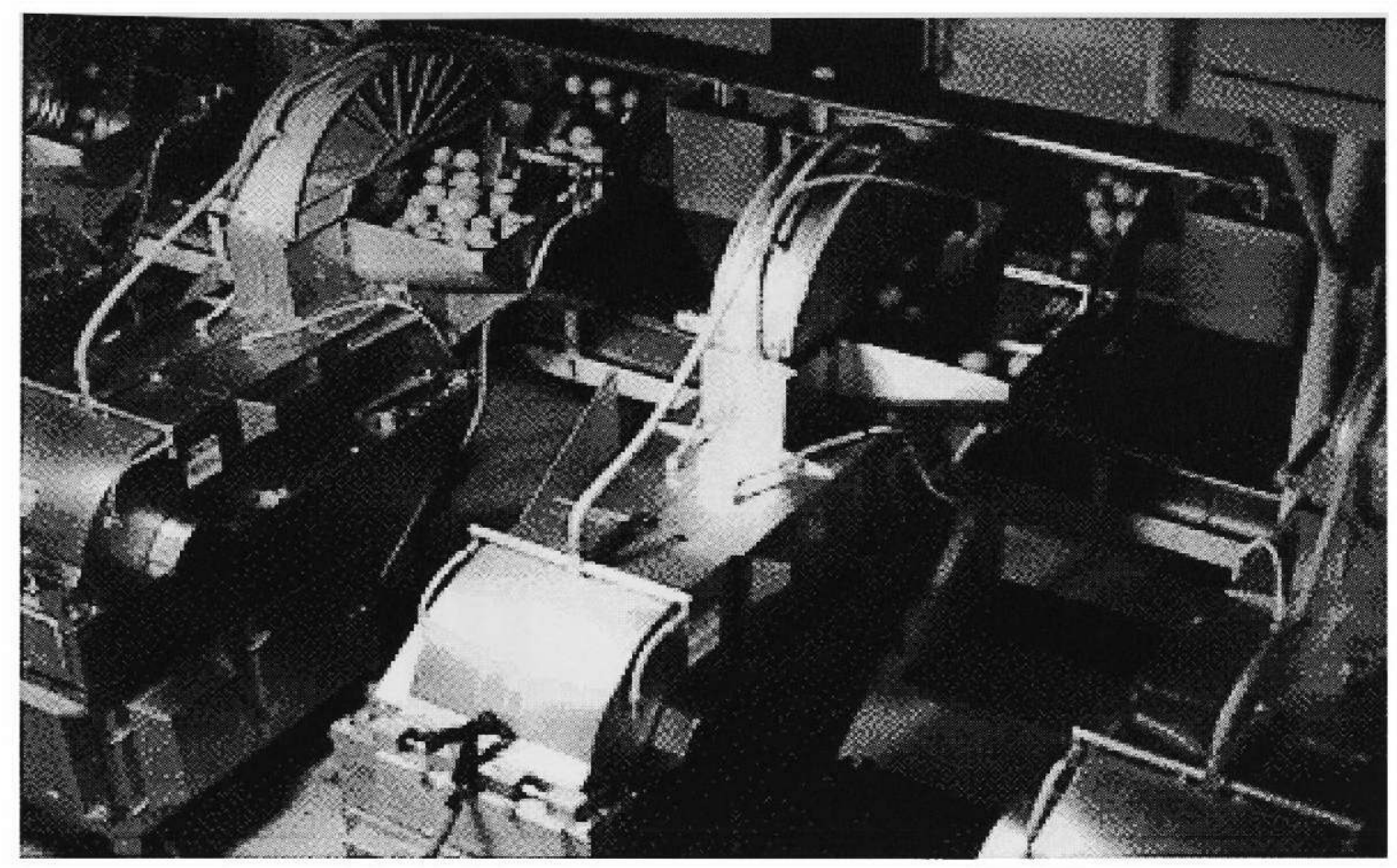

Photograph 13. Juice Extraction

(Townsend, 1999).

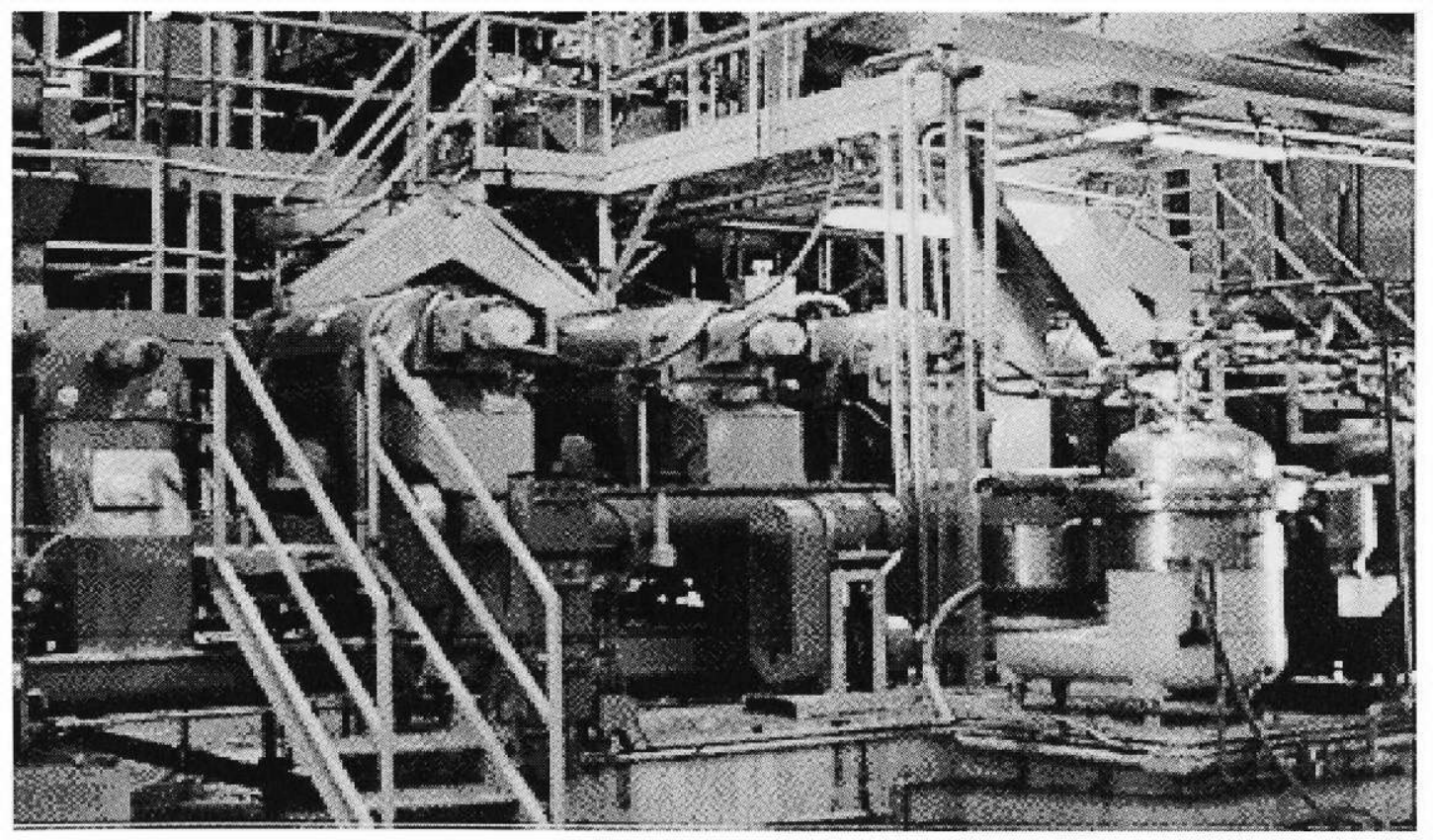

Photograph 14. Screening (Filtering seeds and pulp from juice)

(Townsend, 1999). 


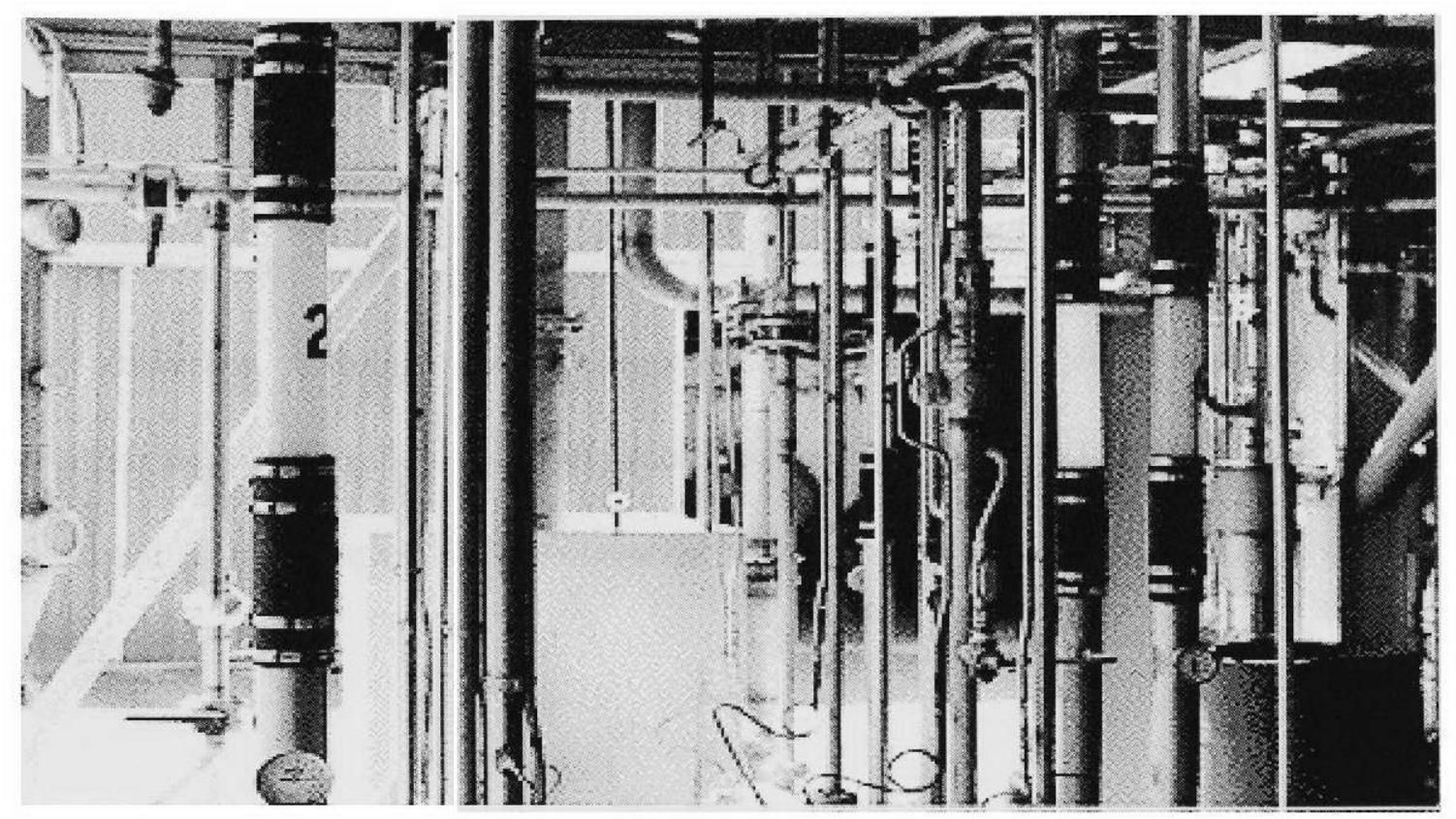

Photograph 15. Juice Being Concentrated

(Townsend, 1999).

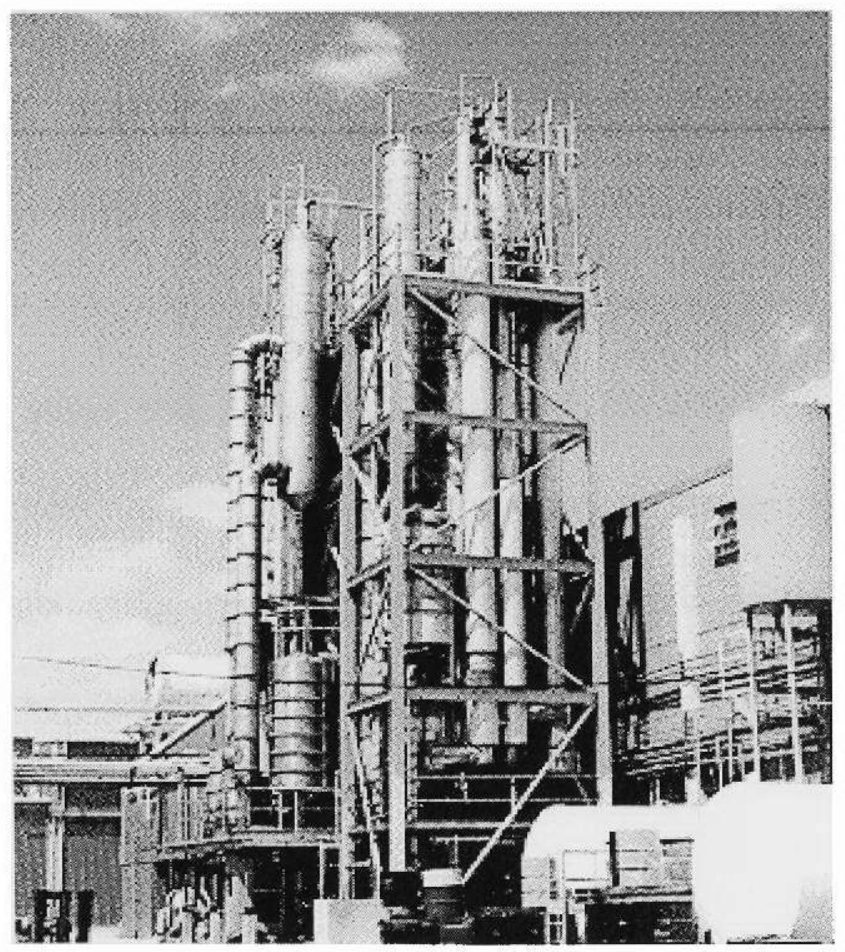

Photograph 16. Evaporation Process

(Townsend, 1999). 
Oil from citrus seed is reaching high commercial levels because of its attractive appearance. The seed oil extraction is similar to any other dried seed (cotton, sunflower) processed to extract oil. Some common operations are flaking, cooking, oil pressurization and extraction, refining, limonin recovery from crude oil, degumming, bleaching, deodorizing, winterization, hydrogentation, and interetirification. The citrus seed hulls are marketed as conditioner for fertilizers or to livestock feeding programs (Ciba-Geigy, 1975).

Dried citrus pulp is the residue from juice extractors. The peel residue is transported by conveyors to a hammer mill where it is segmented into $1 / 4$ to $3 / 4$ inch $(0.6$ $-2.0 \mathrm{~cm}$ ) pieces. Chemical lime is added to the chopped peel to react with pectin and release bound water from the peel. The liquor obtained is processed as another byproduct. The pressed peel is dried in rotating dryers until achieving 6 to $8 \%$ moisture. The citrus pulp and hot combustion gases pass into a cyclone separator to separate dried solids (by gravity) and hot gases and moisture exhaust to the atmosphere. The dried pulp is transported to a cooler until it gets to ambient room temperature. The dried pulp is packaged into $100 \mathrm{lb}(45 \mathrm{~kg}$ ) bags and stored, to market it as animal food (see Photograph 18). Three main byproducts are obtained from the citrus pulp: dust (cyclone), meal (screen), and citrus pulp (The Ultimate Citrus Page, 1999). 


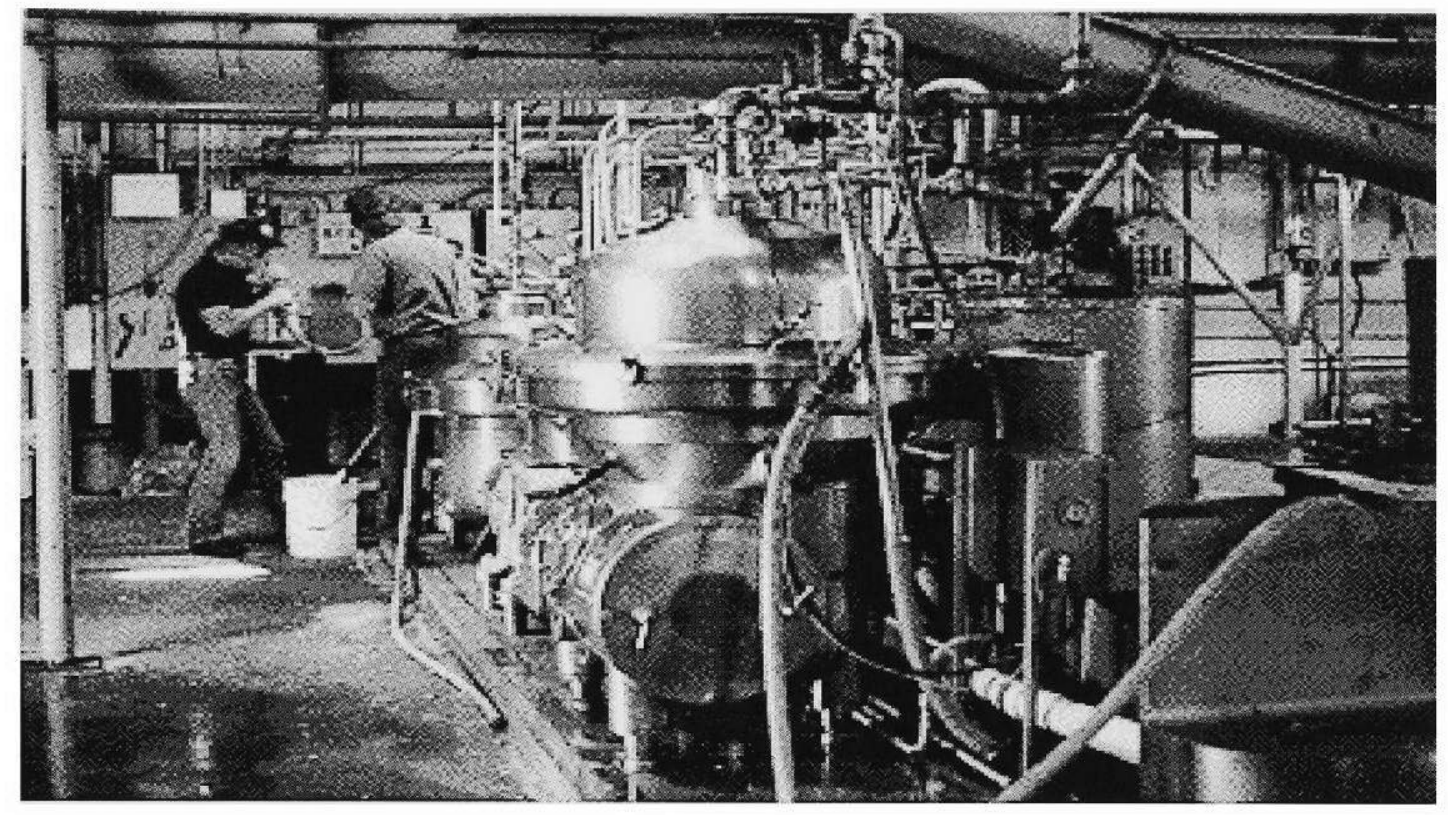

Photograph 17. Citrus Oil Recovery

(Townsend, 1999).

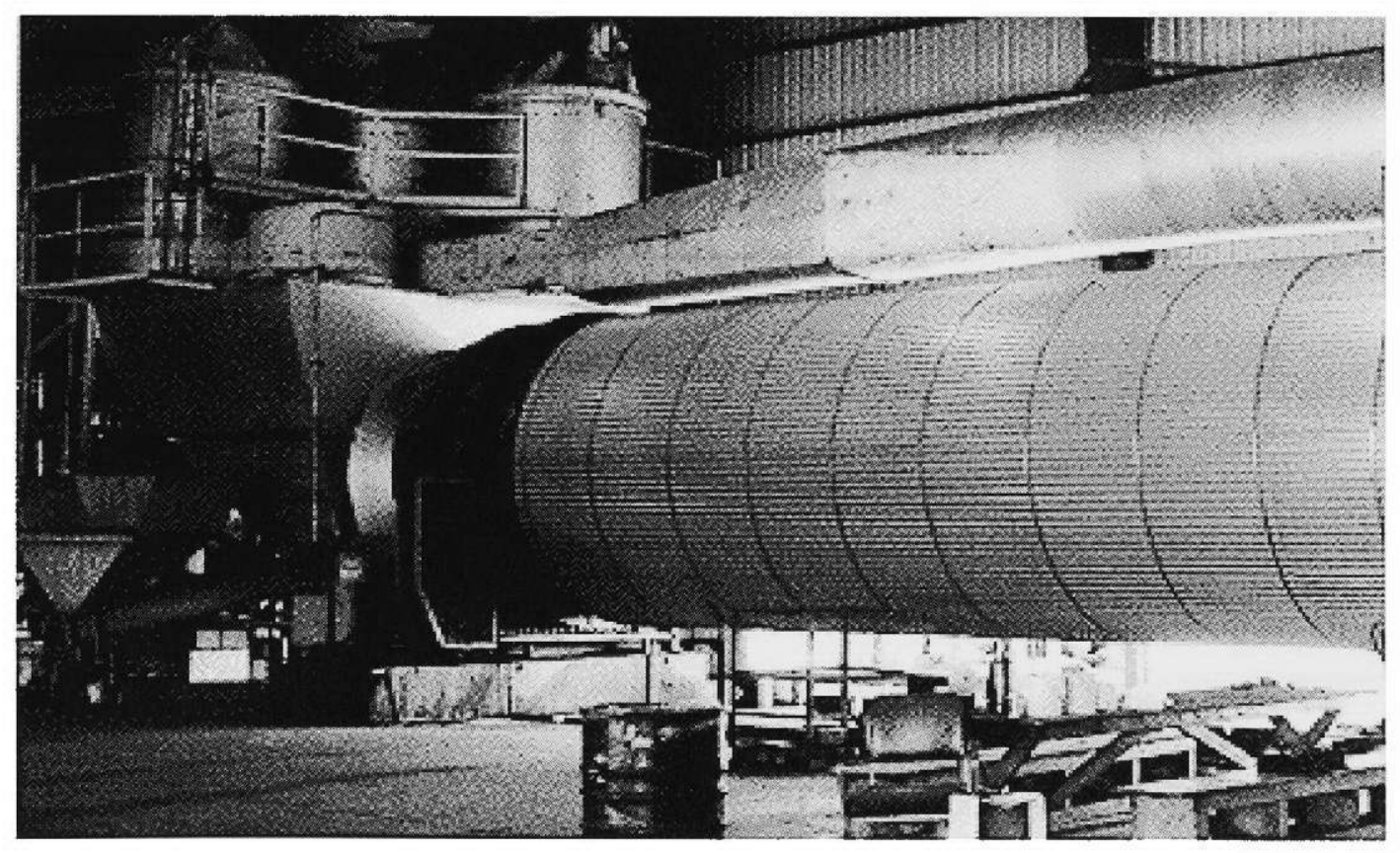

Photograph 18. Peel and Pulp Drying for Cattle Feed

(Townsend, 1999). 
Citrus molasses is obtained by concentrating press liquor from water released in the drying pulp process. The main process for molasses is evaporation until the liquor reached a concentration of $72^{\circ}$ Brix. Then, the concentrated liquor is screened and stored in tanks until pasteurization at $240^{\circ} \mathrm{F}\left(116^{\circ} \mathrm{C}\right)$. The amount of citrus molasses production in Florida is greater than 50,000 tons during processing season. Citrus molasses is used as animal feed and in production of beverages (ethyl alcohol by fermentation) (Townsend, 1999).

Bioflavonoids are obtained from chopped citrus peel by adding an alkaline substance (hydrated lime) to extract them. Hesperidin (for pharmaceutical uses) is extracted at a $\mathrm{pH}$ of $11-11.2$ while naringin (for beverages, food flavors, azo dyes, and neohesperidin dihydrochalcone 1,500 times sweeter than sugar) is extracted at $\mathrm{pH}$ of 8.8 9.0. The production of hesperidin and naringin is approximately $8-10 \mathrm{lb}(3.5-4.5 \mathrm{~kg})$ and $4-8 \mathrm{lb}(1.8-3.5 \mathrm{~kg})$ per ton, respectively (Ciba-Geigy, 1975).

Citrus fruits, especially lemon and lime, are a very important source of pectin. The recovery of pectin in Florida is low compared with California production. An amount of approximately 90 million pounds (40,000 tons) of pectin could be recovered from citrus peel residue. Pectin process operations include preparation of raw material, removal of ballast, acid hydrolysis of protopectin and dissolution of pectin, precipitation of pectin, purification, and drying. Pectin is used in the food industry for preparation of jelly, jam, 
emulsifiers, confectionery, salad dressings, ice creams, glue and mucilages, chemicals, pharmaceuticals, films, and other industry applications (USEPA, 1975).

Washed pulp concentrates and dried juice sacs are produced from vesicles and other pulp portions generated during juice production. This product is called finisher pulp. It can be used to adjust pulp content in final juice product, feed mill or frozen for beverages. Another way is to wash the finisher pulp and dry the residue. The liquor is concentrated to $60^{\circ}$ Brix (Brix degree means a unit for sugar solutions, indicating the percentage by weight of sugar in the solution at a specified temperature) and sold as cloud, flavor or beverage base. The finisher pulp can be dried without washing to produce raw material used in the food and beverage industries (Katsuyama, 1979).

Citrus peel can be sliced and placed in casks and covered with sulfited water to cure the product. Then, the peels are washed, diced, and saturated with syrup $(60 \%$ glucose and $40 \%$ sucrose) for 3 - 4 days. This product is used in the food industry. Fermentation products or alcohol (ethyl) production from citrus molasses is well developed in Florida. Orange, grapefruit, and tangerine can be converted into pleasant wines. Other byproducts produced from citrus wastes are vinegar, mayonnaise, salad oils and dressings, citric acid, lactic acid, bland syrup, chemicals and chemical intermediates, 2,3-butylene glycol, yeast, inositol, dyes, antioxidants, peel seasonings, adhesives, tangeretin, nobiletin, limonin, clouding agents, etc. (Ciba-Geigy, 1975). 


\subsubsection{Packaginghouses (Phase IV - XIV)}

The fresh fruit market is well developed in the citrus industry due to high demand for product. Cosmetic standards are the main factors moving fresh market fruit. The fresh fruit market requires a high degree of control of external blemishes or fungal diseases to meet cosmetic standards and to be marketable. Good fruit appearance leads growers to increase pesticide applications to achieve good quality fruit during harvesting (Florida Agriculture, 1999).

After harvesting, citrus goes to the packinghouse where the fruit is weighed, washed, waxed, and graded. Once the fruit is in plant, it is weighed and transported by belt conveyors to undergo a rough selection where the packing line system starts. Citrus fruits have to be treated with many products to meet fresh market or consumer requirements and improve the operation of the citrus packinghouse. The most regular products used in packinghouses are cleaners, waxes, fungicides, sanitizers, and specialty products including color-add to improve color quality on the fruit. The first preselection of citrus in the packinghouse has the objective of taking away fruit damaged due to transport and management. Following this operation, the fruit is transported via chain conveyor for cleaning and quality sorting where fruit is selected by sizes and shapes. Someplace along the chain conveyor, washers and waxers are constructed to keep line production. During washing, large amounts of water are applied to clean the fruit. This operation uses special brushes that gently brush each fruit surface. The fruit is then 
immersed in tanks filled with water and detergents including negrol and essasol benzene sulphanate. Refer to Tables 23 and 24, which summarize disinfectants and detergents used in citrus packinghouses. Citrus cleaners are added to the fruit based upon growing area and season. Then, fresh water is sprayed over the fruit to rinse it. After rinsing, conveyors transport the fruit to waxers, where wax and fungistatic substances are applied over fruit surface to decrease post-harvest illness. A good wax coating not only improves the shelf life, appearance, and marketability of citrus but also reduces shrinkage and inhibits decay and disease. Tables 25 and 26 refer to Citrosol Company and Danovan Brown \& Associates products used for the post-harvest treatment of citrus (Donovan Brown \& Associates, 1999).

A drying operation comes after waxing. A good effective drying ensures that the fruit exists with a totally uniform dry hard wax coating. Fruit dryers are designed as tunnels where warm air is injected to catch the extra-humidity of fruits. Once the fruit is dried, the packer picks up one layer at a time and places it into the carton. A common practice for some packinghouses is to release fungicides during this operation. The packed fruit is then placed into coolers to bring down the temperature (field heat) of the fruit. After finishing these operations, the fruit is ready to go for temporary storage and then to the supermarkets (Dole Food Company, Inc., 1999). 
Table 23. Disinfectants Used in the Citrus Industry

(Adapted from disinfectant and detergents, Citrosol Company, 1998).

\begin{tabular}{|c|c|c|}
\hline Product and Composition & Action & Application and Dose \\
\hline Ekasol. 2-n-isolthiazolin-3-ona: $4 \%$ & $\begin{array}{ll}- & \text { Disinfectant } \\
\text { - } & \text { Bactericidal } \\
\text { - } & \text { Fungicide } \\
\text { - } & \text { Sporecide }\end{array}$ & $\begin{array}{ll}- & \text { Inmersion }(1 \%) \\
- & \text { Fruit surface pulverization }(1 \%)\end{array}$ \\
\hline $\begin{array}{l}\text { Glocuat. Ammonium Quaternary: } \\
25 \% \mathrm{w} / \mathrm{w}\end{array}$ & $\begin{array}{ll}- & \text { Disinfectant } \\
\text { - } & \text { Bactericidal }\end{array}$ & $\begin{array}{ll}- & \text { Inmersion }(0.2 \%) \\
- & \text { Manual washing }(0.2 \%) \\
- & \text { Fruit surface pulverization }(0.4 \%)\end{array}$ \\
\hline Glutar-Al. Glutraralhyde: $25 \% \mathrm{w} / \mathrm{w}$ & $\begin{array}{ll}\text { - } & \text { Disinfectant } \\
\text { - } & \text { Bactericidal } \\
\text { - } & \text { Fungicide } \\
\text { - } & \text { Sporecide }\end{array}$ & $\begin{array}{ll}- & \text { Inmersion }(0.75 \%) \\
- & \text { Manual washing }(0.75 \%) \\
- & \text { Fruit surface pulverization }(1 \%)\end{array}$ \\
\hline Glyoxon. Glyoxali: $10 \% \mathrm{w} / \mathrm{v}$ & $\begin{array}{ll}- & \text { Disinfectant } \\
\text { - } & \text { Bactericidal } \\
\text { - } & \text { Sporecide }\end{array}$ & $\begin{array}{ll}- & \text { Manual washing }(0.75 \%) \\
- & \text { Fruit surface pulverization }(1 \%)\end{array}$ \\
\hline $\begin{array}{l}\text { Fungicid Ortho. Orthophenylphenate } \\
\text { Sodium: } 20 \% \mathrm{w} / \mathrm{v}\end{array}$ & $\begin{array}{ll}\text { - } & \text { Disinfectant } \\
\text { - } & \text { Fungicide }\end{array}$ & $\begin{array}{ll}- & \text { In drencher }(5 \%) \\
- & \text { Fruit surface pulverization }(5 \%)\end{array}$ \\
\hline $\begin{array}{l}\text { Fungicid Ortho C Hydroxide: } 5 \% \mathrm{w} / \mathrm{v} \\
\text { Orthophenilphenate Sodium: } 5 \%\end{array}$ & $\begin{array}{ll}- & \text { Disinfectant } \\
- & \text { Degreasing } \\
\text { - } & \text { Fungicide }\end{array}$ & - $\quad$ Field boxes washing $(6 \%)$ \\
\hline $\begin{array}{l}\text { Fumispore. Parahydroxyphenylsalicy- } \\
\text { finical: } 5 \% \mathrm{w} / \mathrm{w}\end{array}$ & $\begin{array}{ll}- & \text { Disinfectant } \\
\text { - } & \text { Fungicide }\end{array}$ & - $\quad$ Smoke sprayed in the ambient \\
\hline
\end{tabular}


Table 24. Fresh Fruit Cleaners

(Adapted from Disinfectant and Detergents, Danovan Brown \& Associates, 1998 and Citrosol Company, 1998).

\begin{tabular}{|c|c|c|}
\hline Citrus Cleaners & Description & Application and Dose \\
\hline Fresh Foam 22 & $\begin{array}{l}\text { Alkaline non- } \\
\text { fungicidal cleaner }\end{array}$ & $\begin{array}{l}\text { Dilution 10:1 (1 gallon makes } 10 \\
\text { with water) }\end{array}$ \\
\hline Fresh Foam 26F & $\begin{array}{l}\text { Detergent } \\
\text { Fungicide against } \\
\text { rot diseases and } \\
\text { penicillium molds }\end{array}$ & $\begin{array}{ll}- & \text { Dilution } 10: 1 \\
\text { - } & \text { As a spray, drip, flood, or foam on } \\
\text { fruit over brushes } \\
\text { - } & \text { EPA }^{(1)} \text { Reg. } N^{\circ} .33354-2\end{array}$ \\
\hline Fresh Foam 28 & $\begin{array}{l}\text { Neutral pH } \\
\text { Detergent. To clean } \\
\text { fruit when brought } \\
\text { to the packinghouse }\end{array}$ & - Dilution 50-200:1 \\
\hline Mold Strip 25 & Detergent & $\begin{array}{ll}- & \text { Dilution } 15: 1 \\
- & \text { By foaming, dripping, flooding, or } \\
\text { spraying }\end{array}$ \\
\hline Mold Strip LF & Detergent & $\begin{array}{ll}\text { - } & \text { Dilution 15:1 } \\
\text { - } & \text { In drenchers }\end{array}$ \\
\hline Negrol $^{(2)}$ & $\begin{array}{l}\text { Detergent with } \\
\text { action against the } \\
\text { boldface. }\end{array}$ & $\begin{array}{l}\text { Immersion in a water pool (5- } \\
10 \%) \\
\text { - In a curtain of lather }(5-10 \%)\end{array}$ \\
\hline $\begin{array}{l}{ }^{\mathrm{T} E s s a s o l} \text { Dodesyl Benzene Sulphanat } \\
\text { Sodium Salt, } 4 \% \mathrm{w} / \mathrm{v}\end{array}$ & Detergent & $\begin{array}{ll} & \text { Fruit surface pulverization }(0.5 \%) \\
- & \text { In a curtain of lather }(5-10 \%) \\
- & \text { Immersion in water pool }(5-10 \%)\end{array}$ \\
\hline
\end{tabular}

(1) EPA Registration number is only available for Fresh Foam 26F.

(2) Citrosol Company products. 
Table 25. Citrosol Fungicides and Waxes Used in the Citrus Industry

(Adapted from Citrosol Company, 1998).

\begin{tabular}{|c|c|c|}
\hline Product & Composition & Description and Doses \\
\hline Citrocil & $\begin{array}{l}\text { Imazalil (Sulphhate } \\
\text { form) Ortofenilfenol: } \\
10 \%\end{array}$ & $\begin{array}{l}\text { Fungicide against Penicillium, } \\
\text { Botrytis, and Geotrichum diseases. } \\
\text { In drencher during 25-30 seconds } \\
\text { and } 1 \mathrm{ppt}\end{array}$ \\
\hline \begin{tabular}{|l|} 
Fecundal S-7,5 \\
\end{tabular} & Imazalil: $50 \% \mathrm{w} / \mathrm{v}$ & $\begin{array}{l}\text { Fungicide against Penicillium } \\
\text { Diseases } \\
\text { In drencher during 20-30 seconds } \\
\text { and 5-6 ppt }\end{array}$ \\
\hline Fungicid Ortho & $\begin{array}{l}\text { Orthophenilphenate } \\
\text { Sodic: } 20 \% \mathrm{w} / \mathrm{v}\end{array}$ & - $\quad$ Fungicide \\
\hline Salvator & $\begin{array}{l}\text { Methil-thiophanate: } \\
45 \% \mathrm{w} / \mathrm{v}\end{array}$ & $\begin{array}{l}\text { Fungicide against Penicillium } \\
\text { Diseases } \\
\text { In drencher during 20-30 seconds } \\
\text { and 2-4 ppt }\end{array}$ \\
\hline Mirage 40-Ecna & Prochloraz: $40 \% \mathrm{w} / \mathrm{v}$ & $\begin{array}{l}\text { Fungicide against Penicillium, } \\
\text { Alternaria, and Botrytis diseases } \\
\text { In drencher during 25-30 seconds } \\
\text { and } 2 \text { ppt }\end{array}$ \\
\hline Citrosol A & $\begin{array}{l}\text { Active-Matter: } 18 \% \\
\text { w/v }\end{array}$ & $\begin{array}{l}\text { Wax to last brightneess and good } \\
\text { control in losing weight }\end{array}$ \\
\hline Citrosol A-V & \begin{tabular}{|l} 
Active-Matter: $10 \%$ \\
w/v
\end{tabular} & $\begin{array}{l}\text { Wax to help during degreened cycle } \\
\text { because of ethylene effects }\end{array}$ \\
\hline Citrosol A. Cold Storage & $\begin{array}{l}\text { Active-Matter: } 18 \% \\
\text { w/v }\end{array}$ & $\begin{array}{ll}- & \text { Water wax for treatment } \\
\text { refrigerated fruits storage (up to } 6 \\
\text { months duration) }\end{array}$ \\
\hline Citrosol and Citrosol R & $\begin{array}{l}\text { Cumarona-Indine } \\
\text { Resine: } 9 \% \text { and } 5 \% \\
\text { w/v }\end{array}$ & $\begin{array}{ll}- & \text { Solvent based wax to give } \\
\text { brilliancy to fruit } \\
-\quad & 1.5 \text { to } 2 \text { liters per ton of fruit }\end{array}$ \\
\hline
\end{tabular}


Table 26. Danovan Brown Fungicides and Waxes Used in the Citrus Industry

(Adapted from Danovan Brown \& Associates, 1999).

\begin{tabular}{|c|c|c|}
\hline Product & Description & Application and Doses \\
\hline Color-Add & $\begin{array}{l}\text { Surface dye to enhance } \\
\text { color }\end{array}$ & $-\quad N / A$ \\
\hline Color-Glo & $\begin{array}{l}\text { Surface dye to enhance } \\
\text { color }\end{array}$ & $\begin{array}{ll}- & \text { Dilution } 300: 1 \\
- & \end{array}$ \\
\hline Color-Fresh & $\begin{array}{l}\text { Sodium hypochloride } \\
\text { solution at } 10 \% \text { strength } \\
\text { EPA Reg. } N^{\circ} .43410-69- \\
33354\end{array}$ & - Washing \\
\hline Fresh Ban T & $\begin{array}{l}\text { Thiabendazole Fungicide } \\
\text { EPA Reg. N. } 43410-33- \\
33354\end{array}$ & $\begin{array}{l}\text { - Dilution of } 13.6 \text { ounces in } 100 \\
\text { gallons will give } 1000 \mathrm{ppm} \\
\text { Against rot disease and } \\
\text { penicillium molds }\end{array}$ \\
\hline Fresh Band 4000 & $\begin{array}{l}\text { Thiabendazole Fungicide in } \\
\text { unit package } \\
\text { EPA Reg. } N^{\circ} .43410-7- \\
33354\end{array}$ & $\begin{array}{l}\text { One unit makes } 4000 \mathrm{ppm} \text { in } 55 \\
\text { gallons of wax or water }\end{array}$ \\
\hline Fresh Wax CS 301 & $\begin{array}{l}\text { Inexpensive wax to improve } \\
\text { shine and excellent scuff } \\
\text { resistance }\end{array}$ & $\begin{array}{l}\text { As needed. The fruit has to be } \\
\text { completely dry }\end{array}$ \\
\hline Fresh Wax 3202 & $\begin{array}{l}\text { For high shine and } \\
\text { durability and moderate cost }\end{array}$ & $\begin{array}{l}\text { Require good water elimination } \\
\text { and } \\
\text { drying }\end{array}$ \\
\hline Fresh Wax 3330 & $\begin{array}{l}\text { Premium wax. High shine } \\
\text { citrus wax with high } \\
\text { durability of shine. Good } \\
\text { rewetting and scuff } \\
\text { resistance }\end{array}$ & $-\quad N / A$ \\
\hline Fresh Wax Beta A & $\begin{array}{l}\text { High shine citrus wax with } \\
\text { high durability of shine. } \\
\text { Good rewetting and scuff } \\
\text { resistance }\end{array}$ & $-\quad \mathrm{N} / \mathrm{A}$ \\
\hline Fresh Wax Dura Gloss H.S. & $\begin{array}{l}\text { Premium. High shine citrus } \\
\text { wax with high durability of } \\
\text { shine. Good rewetting and } \\
\text { scuff resistance }\end{array}$ & - It is a high-solids wax \\
\hline Fresh Wax 36CF-R2 & $\begin{array}{l}\text { High shine citrus wax } \\
\text { EPA Reg. N }{ }^{\circ} .33354-17\end{array}$ & $\begin{array}{l}\text { - May be used directly from } \\
\text { container }\end{array}$ \\
\hline
\end{tabular}

(1)EPA Registration number appears only for registered products. 


\subsection{Industry Contamination}

\subsubsection{Pesticides and Other substances}

The environmental contamination by pesticides is classified as two kinds depending on intent of application: intentional or direct contamination and unintentional or indirect contamination (Westlake et al., 1965).

\subsubsection{Intentional}

Intentional or direct contamination means addition of pesticides and other substances by man to protect crops from pest damage or age deterioration. Direct application is used on animals, crops, soil, water, for household and garden use, on mothproofed fabrics for human and house use, etc. However, the purpose of pest and substance control is not to make pesticides and other substances part of the food (Westlake et al., 1965).

\subsubsection{Unintentional}

Unintentional or indirect contamination is the transportation of residual substances through soil, water, air, and wastes to remote places from the original application target (Pratt, 1970). 
Unintentional contamination can come from exposure to industrial materials and wastes (i.e., pesticides, mothproofing plants and other food industry wastes) that reach water, soil, air, and living organisms. For instance, pest control operations may produce drift (i.e., air currents, volatilization, and wind), snowout, and rainout, which can pollute water, soil, and air. In addition, the citrus industry can create contamination from decaying plant tissues, garbage disposal, and residual solid waste (Westlake et al., 1965).

Pesticides may get into citrus products as follows:

1) During preharvest, seed and agricultural land treatment can cause drift; therefore, soil, water, food, and living organisms can be directly affected.

2) During the postharvest period, handling can also pollute because of chemical residues in the raw product, poor treatment of raw product and storage containers, and mishandling of finished product packaging storage areas, etc. (Metcalf, 1965).

\subsubsection{Tolerances for pesticide residues}

The Federal Insecticide, Fungicide, and Rodenticide Act (FIFRA) was amended in 1987 in order to protect human foods from pesticide residues. The Federal Food, Drug, and Cosmetic (FDC) Act also states two goals to use pesticides. These goals are to find the balance between risks and benefits of pesticide uses. Tables 27 and 28 show some data on pesticide residues in the citrus industry (National Research Council, 1987). 
Table 27. Estimated Oncongenic Risk Distribution by Pesticide Type on Fresh and Processed Food (Adapted from National Research Council, 1987).

FRESH FOOD

PROCESSED FOOD

\begin{tabular}{|c|c|c|c|c|}
\hline Pesticide Type & Risk & Percentage $^{I}$ & Risk & Percentage $^{2}$ \\
\hline Fungicide & $2.53 \times 10^{-3}$ & 54.5 & $9.33 \times 10^{-4}$ & 77.8 \\
\hline Herbicides & $1.44 \times 10^{-3}$ & 31.0 & $1.40 \times 10^{-4}$ & 11.6 \\
\hline Insecticides & $6.73 \times 10^{-4}$ & 14.5 & $1.27 \times 10^{-4}$ & 10.6 \\
\hline Total & & 100.0 & & 100.0 \\
\hline $\begin{array}{l}\text { Estimated } \\
\text { risk/percent. } \\
\text { Total estimated } \\
\text { risk. }\end{array}$ & $4.64 \times 10^{-3}$ & $79.4 \sim$ & $1.20 \times 10^{-3}$ & 20.6 \\
\hline
\end{tabular}

${ }^{1}$ These percentages represent fresh or processed food risk by pesticide type.

${ }^{2}$ These are percentages of total dietary risk.

NOTE: Dietary Oncongenic Risk = Exposure (Food consumption $\times$ Pesticide residues $) \times$ Oncongenic Potency

Oncongenic Potency $\left(Q^{*}\right)$ is the slope of the dose response curve from animal tests yielding a positive Oncongenic response. $\mathrm{Q}^{*}=$ tumors $/ \mathrm{mg}$ of pesticide $/ \mathrm{kg}$ of body weight $/$ day.

Table 28. Greatest Estimated Oncongenic Risk from Fungicides in Oranges

(Adapted from National Research Council, 1987).

ESTIMATED RISK

\begin{tabular}{|l|l|l|l|l|}
\cline { 2 - 5 } $\begin{array}{c}\text { Active } \\
\text { Ingredient }\end{array}$ & \multicolumn{1}{|c|}{ Raw Food } & Processed Food & \multicolumn{1}{c|}{ Total } & $\begin{array}{c}\text { Risk From } \\
\text { Fungicides on } \\
\text { Crops (\%) }\end{array}$ \\
\hline Zineb & $2.07 \times 10^{-5}$ & $1.42 \times 10^{-5}$ & $1.62 \times 10^{-4}$ & 43 \\
\hline Captan & $9.68 \times 10^{-6}$ & $6.62 \times 10^{-5}$ & $7.58 \times 10^{-5}$ & 20 \\
\hline Folpet & $8.84 \times 10^{-6}$ & $6.04 \times 10^{-5}$ & $6.92 \times 10^{-5}$ & 9 \\
\hline Benomyl & $3.48 \times 10^{-6}$ & $2.38 \times 10^{-5}$ & $2.72 \times 10^{-5}$ & 7 \\
\hline O-Phenylphenol & $2.64 \times 10^{-6}$ & $1.81 \times 10^{-5}$ & $2.07 \times 10^{-5}$ & 6 \\
\hline
\end{tabular}




\subsection{Assessment Sources and Environmental Significance}

The preliminary assessment of the citrus industry conducted in this study offers alternatives and opportunities to pollution problems in agriculture and the processing operations applied following harvest, water usage, and disposal of wastes generated. This study reviewed a wide number of government documents to evaluate prevention-ofpollution alternatives. Documents reviewed include the Federal Drug Administration (FDA) regulations, the Environmental Protection Agency (EPA) limits and standards, Florida Laws and Rules, Florida Citrus Pest Management Guide, as well as scientific and engineering journals and magazines. Scientific and engineering journals, such as Environmental Contamination Toxicology Journal, Pollution Engineering, Food Technology Journal, Journal of Environmental Quality, Institute of Food and Agricultural Sciences (IFAS), The Citrus Industry Magazine, The Journal of Horticultural Science, Journal of the Science of Food and Agriculture, Journal of Food Engineering, Florida Water Resources Journal, and The Environmental Magazine, were considered to support this study.

The FDA manuals set contamination tolerances to protect both public health and environment. Environmental impacts need characterization to permit evaluation of prevention-of-pollution opportunities. In addition, there are food regulations under the Federal Food, Drug, and Cosmetic Act (FDC), Section 408, regarding pesticides: "explicitly recognizes that pesticides confer benefits and risks and that both should be 
taken into account in setting raw commodity tolerances." Section 409 of the Federal Food, Drug, and Cosmetic Act lists some chemical residues that concentrate in processed food, which are considered as food additives.

Prevention-of-pollution programs are a priority focus for the USEPA achieved by improving industrial production, conserving natural resources, and reducing wastes. There are four options to be considered for the citrus industry in improving environmental management: preventing pollution at the source; reusing, recycling, and recovering materials; waste treatment; and waste disposal.

USEPA establishes and regulates standard tolerance levels of pesticide residues on raw commodities. These regulations are published in Section 408 of the FDC Act. The Florida Pesticide Laws and Rules (Florida Statutes Chapter 487) contain regulations governing the distribution, sale, and use of pesticides to protect human beings and the environment from the adverse effects of pesticides. The Florida Department of Agriculture and Consumer Services (DACS) has the primary responsibility to administer the mentioned law (DACS, 1992).

The Dade County Department of Environmental Resources Management (DERM) has provided technical assistance to local food industries to produce healthier and safer foods while keeping the environment cleaner and safer. 
The Florida Citrus Pest Management Guide is a tool to select pesticides for the citrus industry based on the following factors: resistance of the pesticide to biodegrade in the ecosystem, efficiency and application rates, economic justification, product selection, timing, placement in relation to the root system, weed cover, soil properties, and impact on the environment.

\subsection{Citrus Industry Listing}

The ISO 14000 standards in the citrus industry are quite new. Therefore, the opportunity to get citrus industrialists involved in ISO 14000 activities is a proactive action to mitigate negative environmental impacts and support citrus sustainable business development. Application of ISO 14000 standards is a voluntary program; however, implementation of this standard in the citrus industry will integrate management of

environmental practices. In addition, ISO 14000 will prevent noncompliance with environmental regulations. The Florida Department of Citrus each year publishes a list of companies licensed and registered to manage citrus business. Each member is associated with an organization depending on the type of business that they have. In addition, each associated member associates sub-members who belong to same type of business. Table 29 lists main citrus organizations according to the Florida Department of Citrus (The Florida Department of Citrus, 1999). 
Table 29. Citrus Companies Licensed and Registered 1998-1999 Season

(The Florida Department of Citrus, 1999).

\begin{tabular}{|c|c|}
\hline Type of Association & Company Name \\
\hline \multicolumn{2}{|c|}{ Growers } \\
\hline MERICAN CITRUS PRODUCTS CORPORATION / & FRUITLANDS FARM \\
\hline DBA: Florida Home Juice Company & IMG CITRUS, INC. \\
\hline ANAPA CORPORATION & JACKSON BROTHERS GROVES, INC. \\
\hline BANES GROVES & MANATEE FRUIT COMPANY \\
\hline BLOOD'S HAMMOCK GROVES, INC. & McKINNON CORPORATION \\
\hline CALLERY JUDGE GROVE, LP / DBA: Direct from the & OVERLOOK GROVES, INC. \\
\hline Grove & RUSSAKIS GROVES \\
\hline COLLINS, HAROLD M. & UMATILLA CITRUS GROWERS ASSOCIATION \\
\hline CRITTENDEN FRUIT COMPANY, INC & \\
\hline \multicolumn{2}{|c|}{ Intermediate Handlers } \\
\hline A.B. ROBINSON FRUIT \& PRODUCE & KAHN GROVE SERVICE COMPANY \\
\hline ABC FRUIT COMPANY & KAZAROS, ROBERT S. \\
\hline ADAMS FRUIT COMPANY, INC. & KING ENTERPRISES CITRUS \& CATTLE, INC. \\
\hline AGRIMANAGEMENT, INC. & KIRKLAND HARVESTING, INC. / DBA: Tropical Fruit \\
\hline ALLEN FRUIT COMPANY, INC. & Company \\
\hline ALTURAS CITRUS FRUIT CO., INC. & KRYSTAL CITRUS, INC. \\
\hline ARCADIA CITRUS ENTERPRISES, INC. & KUMQUAT GROWERS, INC. \\
\hline ARLINGTON ROLLE CITRUS, INC. & L. DICKS, INC. \\
\hline ATKINSON GROVE SERVICE, INC. & LARRY SULLIVAN HARVESTING \\
\hline AUBURNDALE FRUIT CO., INC. & LEE, II, D.C. \\
\hline B \& B CITRUS CO., INC. & LEWIS \& DURRANCE FRUIT CO., INC. \\
\hline B.L. LANIER FRUIT COMPANY, INC. & LIER GROVES, INC. \\
\hline BANANA BRANCH FRUIT COMPANY, INC. & LLOYD'S HARVESTING, INC. \\
\hline BARBEN FRUIT COMPANY, INC. & M.E. STEPHENS \& SONS FRUIT COMPANY, INC. \\
\hline BECKER INDIAN RIVER FRUIT CO., INC. & MANATEE RIVER GROVES, INC. \\
\hline BEE SWEET CITRUS & MANUEL CITRUS, INC. \\
\hline BENTLEY BROTHERS, INC. & MARDIS CITRUS, INC. \\
\hline BEUTTELL, GEORGE M. & McKINNON CORPORATION \\
\hline BEVILLE CITRUS & MEANS, TRESSIE L. \\
\hline BIG ISLAND FRUIT & MENYFOAL FRUIT CO., INC. \\
\hline BLOOD'S HAMMOCK GROVES, INC. & MET/DOLE - JOINT VENTURE / DBA: Dole Citrus \\
\hline BOB PAUL, INC. & Florida \\
\hline BOREE INDUSTRIES, INC. & MICHAEL S. MURPHY, INC. \\
\hline BOWEN BROTHERS FRUIT COMPANY, INC. & MIKE LANGLEY CITRUS, INC. \\
\hline BREWER, JAMES D. & MIXON-SUMMERALL \\
\hline BROWNLEE CITRUS, INC. & MOYE FARMS \\
\hline BRYAN PAUL CITRUS, INC. & N.R. WILLIAMS, INC. \\
\hline BUSBEE, WILKINS \& SEALY, INC. & NAVUM DEVELOPMENT CORPORATION \\
\hline C \& L HARVESTING, INC. & NELSON \& COMPANY, INC. \\
\hline C.J. FRUIT, INC. & NOELKE CITRUS, INC. \\
\hline CAMPBELL \& SONS FRUIT COMPANY, INC. & OAKLEY GROVES, INC. \\
\hline CAMPBELL GROVE CARE, INC. & OLIVER, CLENSTONE \\
\hline CAMPBELL HARVESTING & ORANGE BEND HARVESTING, INC. \\
\hline CARL M. WILBURN, INC. & ORANGE BLOSSOM CITRUS, INC. \\
\hline CARPENTER FRUIT COMPANY, INC. & ORANGE BLOSSOM HARVESTING, INC. \\
\hline CENTER STATE HARVESTING \& HAULING, INC. & ORANGE BLOSSOM INDIAN RIVER CITRUS \\
\hline CENTRAL GROVES CORPORATION & ORANGEFIELD CITRUS, INC. \\
\hline CHAPMAN FRUIT CO., INC. & ORGANICS, INC. \\
\hline CHARLIE WALKER \& SONS & P.H. FREEMAN \& SONS, INC. \\
\hline CITRUS SOURCE, INC. & PANDOLPH, JOSEPH FRANK \\
\hline
\end{tabular}


Table 29. Citrus Companies Licensed and Registered 1998-1999 Season (Cont.)

(The Florida Department of Citrus, 1999).

\begin{tabular}{|c|c|}
\hline Type of Association & Company Name \\
\hline \multicolumn{2}{|c|}{ Intermediate Handlers (Cont.) } \\
\hline CONOLEY FRUIT HARVESTER, INC. & PANTUSO, INC. \\
\hline COOK, SR., B.E. & PARADISE CITRUS SALES, INC. \\
\hline CORBITT CITRUS HAULING, INC. & PARAMOUNT CITRUS, INC. \\
\hline CRITTENDEN FRUIT COMPANY, INC. & PEACE VALLEY ENTERPRISE, INC. \\
\hline CRITTENDEN LANGLEY FRUIT COMPANY, INC. & PELL'S CITRUS \& NURSERY \\
\hline CRUMBLY BROTHERS FRUIT COMPANY & PETELAINE, INC. \\
\hline CRUTCHFIELD \& SONS, INC. & PHILLIPS, JAMES M. \\
\hline CULLIFER FRUIT SCALE, INC. & PLANT FRUIT COMPANY \\
\hline D \& K HARVESTING, INC. & R.L. PEARSON \& SONS, INC. \\
\hline D. GLEN BRANNEN, INC. & RALPH W. JONES, INC. \\
\hline DAVIS \& GAINES, INC. & REITER CITRUS, INC. \\
\hline DAVIS CITRUS \& PACKING CO. & REPUBLIC GROVES, INC. \\
\hline DeVANE HARVESTING, INC. & RICHARD MCKENZIE \& SONS, INC. \\
\hline DEL ORO JUICE MARKETING, INC. & RICHARDSON \& COMPANY, INC. \\
\hline DONLEY CITRUS, INC. & RIDGE HARVESTING, INC. \\
\hline DONNIE SELPH FRUIT COMPANY, INC. & RIO INDIO FRUIT COMPANY \\
\hline DOOLEY GROVES, INC. & RIVER COUNTRY CITRUS, INC. \\
\hline DOUBLE G CITRUS, INC. & RIVER HOUSE MARKETING CORPORATION \\
\hline DOUGLAS CITRUS & RIVERFRONT GROVES GIFT FRUIT SHIPPERS, INC. \\
\hline DUNSON HARVESTING, INC. & RIVERGOLD, INC. \\
\hline EASTERN CITRUS, INC. & ROBERT S. CONGDON HARVESTING, INC. \\
\hline EDWARDS FRUIT COMPANY & ROBINSON FRUIT HARVESTOR, INC. \\
\hline ESTES CITRUS, INC. & ROGERS BROTHERS FRUIT CO. \\
\hline EVANS PACKING COMPANY & ROLLINS FRUIT COMPANY, INC. / DBA: Rollins Fruit \\
\hline EXECUTIVE HARVESTING, INC. & Co. / DBA: Rollins RONNIE'S CITRUS, INC. \\
\hline FARYNA GROVE CARE \& HARVESTING & ROY F. ROBERTS \& SON GROVES, INC. \\
\hline FIVE STAR PACKING & RUSSAKIS GROVES \\
\hline FLORASTAIT CITRUS HAULERS, INC. & RUSSELL, R.M. \\
\hline FLORGANICS SALES, INC. & SAND MOUNTAIN CORPORATION \\
\hline FLORIDA SELECT JUICES, INC. & SAXON FRUIT COMPANY \\
\hline FLOYD L. WRAY MEMORIAL FOUNDATION, INC. / & SCARBOROUGH FRUIT COMPANY, INC. \\
\hline DBA: Flamingo Gardens & SCOTT MARKETING GROUP, INC. \\
\hline FRANKLIN FRUIT CO., INC. & SIMPSON, JR., ALFRED \\
\hline FRESHCO, LTD. & SORRELLS BROTHERS PACKING CO., INC. \\
\hline FRUIT GROWERS HARVEST, INC. & SOUTH FLORIDA FRUIT, INC. \\
\hline FULFORD CITRUS, INC. & SOUTH LAKE APOPKA CITRUS GROWERS \\
\hline GAPWAY GROVE CORPORATION & ASSOCIATION \\
\hline GEORGE MASON CITRUS, INC. & STATON CITRUS HARVESTING \& HAULING, INC. \\
\hline GEORGE WOODS CITRUS & STORY GROVE SERVICE, INC, \\
\hline GRACEWOOD FRUIT COMPANY / DBA: Belair & STRAZZULA BROTHERS CO., INC. \\
\hline Packing House Joint & SUN HILL CITRUS, INC. \\
\hline GRUBBS CITRUS, INC. & SUN TROPIC CITRUS, INC. \\
\hline GULFSTREAM HARVESTING, INC. & SUNRIDGE HARVESTING CO. \\
\hline H. GIVEN CITRUS & SUNBELT CITRUS, INC. \\
\hline H. JENNINGS ROU, INC. & SUNBURST CITRUS COMPANY, INC. \\
\hline HAMMOCK CITRUS CORPORATION & SUNNY RIDGE CITRUS CO. \\
\hline HARRIS, JAMES H. & SUNSHINE FRUIT COMPANY, INC. \\
\hline HAYS HARVESTING, INC. & SURRATT HARVESTING, INC. \\
\hline HEYWARD, HARRY & SWEAT, H.G. \\
\hline HILLIARD GROVE, INC. & T.A. WEEKS \& ASSOCIATES, INC. \\
\hline HOGAN \& SONS, INC & TARVER, LEOFUS \\
\hline
\end{tabular}


Table 29. Citrus Companies Licensed and Registered 1998-1999 Season (Cont.)

(The Florida Department of Citrus, 1999).

\begin{tabular}{|c|c|}
\hline Type of Association & Company Name \\
\hline \multicolumn{2}{|c|}{ Intermediate Handlers (Cont.) } \\
\hline HYMES' CITRUS & THE GREAT FRUIT COMPANY, INC. \\
\hline INDIAN RIVER TRANSPORT CO. & THE WICKIE COMPANY \\
\hline INGRAM GROVE SERVICE, INC. & THOMAS E. DAVIS, INC. \\
\hline INGRAM HARVESTING & TOM WEST, INC. \\
\hline INLAND FRUIT CO. & TREASURE COAST FARMS, INC. \\
\hline INTERIOR CITRUS MARKETING, INC. & TRI BRITTON, INC. \\
\hline J \& S FRUIT & TRINITY CITRUS, INC. \\
\hline J 4 CITRUS, LLC & TROPIC SUN FRUIT CO., INC. \\
\hline J.A.M. FARMS CORP. & TURNER FOODS CORPORATION \\
\hline J.E. McLEAN \& SONS, INC. & U \& H CARETAKING, INC. \\
\hline J.T. CLINE, INC. & VARN CITRUS, INC. \\
\hline JHC GROVES, INC. & VAZQUEZ HARVESTING \\
\hline JLC FARMS, INC. & VERNON DIXON HARVESTING, INC. \\
\hline JACK D. SOLES, INC. & VICTORY GROVES, INC. \\
\hline JACK M. BERRY, INC. & W.A. ALFORD HARVESTING, INC. \\
\hline JACKSON BROTHERS GROVES, INC. & W.C. LEE, INC. \\
\hline JACKSON CITRUS, INC. & W.R. DANIELS CITRUS HARVESTING, INC. \\
\hline JAMES HAMILTON HARVESTING COMPANY & WALKER CITRUS FRUITS, INC. \\
\hline JERIL R. CLENNEY, INC. & WARDLAW \& DICKINSON, INC. \\
\hline JEWELLS OF FLORIDA & WATSON FRUIT CO. \\
\hline JOE L. DAVIS, JR. GROVES \& RANCH & WESLEY CARTER, JR. CITRUS \\
\hline JOHN LANGFORD, INC. & WEST STAR CITRUS PACKING ASSOCIATION \\
\hline JOHN STEPHENS, INC. & WHEELER, DAVID P. \\
\hline JONES, HENRY LEE & WHIDDON, III, FRANK C. \\
\hline \multicolumn{2}{|c|}{ Brokers } \\
\hline A.J. SALES COMPANY & IRISH ENTERPRISES, INC. \\
\hline A.V. CITRUS SALES, INC. / DBA: Harbor Island Sales & JIM RASH, INC. \\
\hline ALDECO, INC. & JOHN J. O'HEARN, JR. PRODUCT COMPANY \\
\hline ALLEN ASSOCIATES & KNIGHT'S CERTIFIED ORGANICS, INC. \\
\hline ANNA'S FRUIT & KUMQUAT GROWERS, INC. \\
\hline B.B.I. PRODUCE, INC. & L.A. WROTEN CO., INC. \\
\hline BEUTTELL, GEORGE M. & McLEAN MARKETING, INC. \\
\hline BEVILLE CITRUS & MORGAN FRUIT DISTRIBUTORS \\
\hline BRETT BLACKMON, INC. & MOYE FARMS \\
\hline BROWNING \& SONS, INC. & MUTUAL CITRUS SALES, INC. \\
\hline BRUCE LEBER CO. & ORGANICS, INC. \\
\hline $\begin{array}{l}\text { CITRISERVICES, INC. / DBA: W.H. Schilbe Citrus } \\
\text { Brokerage }\end{array}$ & $\begin{array}{l}\text { ORYAL EXPORT COMPANY / DBA: Oryal Trading } \\
\text { Company }\end{array}$ \\
\hline CITRUS INTERNATIONAL \& ASSOCIATES, INC. & OSHAWA GROUP PRODUCE, INC. \\
\hline CITRUS PLUS, INC. & PARADISE PRODUCE DISTRIBUTORS, INC. \\
\hline DLF INTERNATIONAL, INC. & PREMIER JUICES \\
\hline FARMER'S PRIDE, INC. & RIOMAR MARKETING, INC. \\
\hline FARMERS POTATO DISTRIBUTING CO., INC. & RIVERSIDE FRUIT SALES, INC. \\
\hline FLORGANICS SALES, INC. & ROLLINS FRUIT CO., INC. / DBA: Rollins Fruit Co. / \\
\hline FLORIDA AGRICULTURAL & DBA: Rollins Grove ROONEY FOODS, INC. \\
\hline ASSOCIATION, INC. & S.D.L. \\
\hline FLORIDA BULK SALES, INC. & SCOTT MARKETING GROUP, INC. \\
\hline FLORIDA FRESH PAK CORPORATION & STIRN MARKETING \\
\hline FLORIDA QUALITY PRODUCTS, INC. & SUNBASE USA, INC. \\
\hline FLORIDA SELECT JUICES, INC. & SUNNY FRESH CITRUS EXPORT \& SALES CO. \\
\hline
\end{tabular}


Table 29. Citrus Companies Licensed and Registered 1998-1999 Season (Cont.)

(The Florida Department of Citrus, 1999).

\begin{tabular}{|c|c|}
\hline Type of Association & Company Name \\
\hline \multicolumn{2}{|c|}{ Brokers (Cont.) } \\
\hline FOOD MARKETING INTERNATIONAL, INC. & T \& M PRODUCE COMPANY, INC, \\
\hline FRESH 1 MARKETIN & TANGERITE GROVES \\
\hline FRESH NECTARS COMPANY / DBA: Heart Kiss Fresh & THE C.W. EMANUEL CO., INC. \\
\hline Fruit Co. & TRINITY CITRUS, INC. \\
\hline FRESH PACIFIC FRUIT \& VEGETABLES, INC. / & TROPICAL JUICE SERVICES, INC. \\
\hline DBA: Paradise Packers & TROPICAL PRODUCTS, INC, \\
\hline FRONTIER FRESH, INC. & TUXEDO FRUIT COMPANY \\
\hline FROSTPROOF CITRUS SALES, INC. & UNITED CITRUS MARKETING, INC. \\
\hline GLENWICK INTERNATIONAL, INC. & VERDELLI FARMS, INC. - CITRUS DIVISION \\
\hline GRACEWOOD MARKETING, INC. & VICTORY GROVES, INC. \\
\hline GULFSTREAM CITRUS SALES, INC. & VITAMIN C FOR THE CAUSE, INC. \\
\hline H. DONOVAN BROWN, PhD. \& ASSOCIATES, INC. & Wm. G. ROE \& SONS, INC. / DBA: Blue Lake Citrus \\
\hline $\begin{array}{l}\text { HEAVENLY FLORIDA CITRUS } \\
\text { IMPERIAL GROUP, INC. }\end{array}$ & $\begin{array}{l}\text { Products } \\
\text { WARREN FRUIT COMPANY, INC. }\end{array}$ \\
\hline CITRUS, INC. & WEST STAR CITRUS PACKING ASSOCIATION \\
\hline \multirow{2}{*}{\multicolumn{2}{|c|}{ Processors }} \\
\hline A. DUDA \& SONS, INC. / DBA: A. Duda \& Sons & \\
\hline Cooperative Association / DBA: Daybreak Farms / DBA: & Spray Cranberries / DBA: Mystic Farms \\
\hline Citrus & ORANGE CO OF FLORIDA, INC. \\
\hline ARDMORE FARMS, INC. & PARMAN KENDALL CORPORATION \\
\hline BECKER INDIAN RIVER FRUIT CO., INC. & PEACE RIVER CITRUS PRODUCTS, INC. \\
\hline CARGILL CITRO AMERICA, INC. & PUBLIX SUPER MARKETS, INC. \\
\hline CAULKINS INDIANTOWN CITRUS CO. & SFE CITRUS PROCESSORS, LP / DBA: Florida Global \\
\hline CITROSUCO NORTH AMERICA, INC. & Citrus Limited \\
\hline CITRUS SERVICE, INC. & SECO DAIRIES OF FLORIDA, INC, / DBA: Golden \\
\hline CITRUS WORLD, INC. & "100" \\
\hline CUTRALE CITRUS JUICES USA, INC. & SILVER SPRINGS CITRUS, INC. \\
\hline FLORIDA CITRUS JUICES, INC. & SOUTHERN GARDENS CITRUS \\
\hline FLORIDA NATURAL FLAVORS, INC. & CORPORATION / DBA: SUN PAC FOODS, INC. \\
\hline FLORIDA SELECT CITRUS, INC. & SUNPURE, LTD. / DBA: Indian River Foods \\
\hline GOLDEN GEM GROWERS, INC. & TAMPA JUICE SERVICE, INC. \\
\hline GUSTAFSON'S PROCESSING \& PACKAGING CO. & T.G. LEE FOODS. INC. \\
\hline H \& H PRODUCTS CO. & THE FRESH JUICE COMPANY OF FLORIDA, INC. \\
\hline HOLLY HILL FRUIT PRODUCTS CO., INC. & THE MINUTE MAID COMPANY \\
\hline JUICE BOWL PRODUCTS, INC. & TROPICANA PRODUCTS, INC. \\
\hline KMC CITRUS ENTERPRISES, INC. & VELDA FARMS, INC. \\
\hline LYKES PASCO, INC. & Wm. G. ROE \& SONS, INC. / DBA: Blue Lake Citrus \\
\hline M \& B PRODUCTS, INC. & Products \\
\hline McARTHUR DAIRY, INC. & WINN DIXIE STORES, INC. \\
\hline MID FLORIDA FREEZER WAREHOUSES, LTD. & WINTER GARDEN CITRUS, INC. \\
\hline \multicolumn{2}{|c|}{ Shippers } \\
\hline A. DUDA \& SONS, INC. / DBA: A. Duda \& Sons & JOSHUA CITRUS, INC. \\
\hline Cooperative Association / DBA: Daybreak Farms / DBA: & KATROS GROVES \\
\hline Citrus & KRYSTAL CITRUS, INC. \\
\hline A.S. HERLONG PACKING COMPANY, INC. & KUMQUAT GROWERS, INC. \\
\hline N FRUIT COMPA & L "N" B GROVES \\
\hline ALTURAS CITRUS FRUIT CO., INC. & LAKE COUNTY CITRUS SALES, INC. \\
\hline ASSOCIATED FRUIT PACKERS, INC. / DBA: & LAKE PLACID CITRUS COOPERATIVE \\
\hline McSweeney Groves & LAKE REGION PACKING ASSOCIATION \\
\hline
\end{tabular}




\section{Table 29. Citrus Companies Licensed and Registered 1998-1999 Season (Cont.)}

(The Florida Department of Citrus, 1999).

\begin{tabular}{|c|c|}
\hline Type of Association & Company Name \\
\hline \multicolumn{2}{|c|}{ Shippers (Cont.) } \\
\hline ASSOCIATED FRUIT PACKERS, INC. & LAKE WALES CITRUS GROWERS ASSOCIATION \\
\hline BEN CRISAFULLI GROVES & LEROY E. SMITH'S SONS, INC. \\
\hline BEN HILL GRIFFIN, INC. & LUKE'S GROVE \\
\hline BERNARD EGAN \& COMPANY / DBA: Egan Packing & LYKES PASCO PACKING CO. \\
\hline Co. DBA St. Lucie Packing Co. / DBA: Egan Fickett Fort & MANATEE RIVER GROVES, INC. \\
\hline Pierce DBA Heart Kiss / DBA: DNE Sales International & MAXWELL GROVE SERVICE, INC. / DBA: Maxwell \\
\hline DBA DNE World Fruit Sales / DBA: Orange Ring DBA & Groves \\
\hline Egan's Orange Ring & MECCA FARMS, INC. \\
\hline BISHOP FRUIT CO., INC. & MIMS CITRUS GROWERS ASSOCIATION \\
\hline BLUE RIBBON CITRUS PACKERS, INC. & MINTON SUN, INC. \\
\hline BOUDRIAS GROVES, INC. & MIXON FRUIT FARMS, INC. \\
\hline BOYETT'S CITRUS PACKERS & MOYE FARMS \\
\hline BROWNS GROVE & MULRENNAN GROVES LTD. RETAIL \\
\hline BUCK CREEK GROVES & N.R. WILLIAMS, INC. \\
\hline CFC PACKING CO. & NEVINS FRUIT COMPANY, INC. \\
\hline CALLERY JUDGE GROVE, LP / DBA: Direct from the & NEW GARDEN GROVES \\
\hline Grove & NOKOMIS GROVES, INC. \\
\hline CAMPBELL'S GROVE & O'DELL GROVES, INC. / DBA: O'Dell Citrus Shop \# 1 \\
\hline CARTER'S PRODUCE, INC. & ORANGE BLOSSOM GROVES \\
\hline CITRUS COUNTRY GROVES OF FLORIDA, INC. & ORANGE BLOSSOM INDIAN RIVER CITRUS \\
\hline CONOLEY CITRUS PACKERS, INC. & OSLO CITRUS GROWERS ASSOCIATION \\
\hline CONSOLIDATED TOMOKA LAND CO. / DBA: Lake & OWENS GROVE \\
\hline Placid Groves & PALM BEACH GROVES \\
\hline COOPER, DONALD A. & PEACE RIVER PACKING COMPANY \\
\hline COUNTY LINE FRUIT COMPANY, INC. / DBA: & PELL'S CITRUS \& NURSERY \\
\hline Murphy Groves DAVIDSON CITRUS & PETERSON'S GROVES \& NURSERY, INC. \\
\hline SHOP, INC. & PETERSON, JR., AXEL T. \\
\hline DAVIS CITRUS FARMS & POLICICCHIO GROVES \\
\hline DAVIS CITRUS \& PACKING CO. & PRESHER BROTHERS CITRUS \\
\hline DIRNBERGER FARMS, INC. & PRESSLEY DAVIS, INC. \\
\hline DOLE CITRUS, INC. / DBA: Dole Citrus / DBA: S \& S & PROCTOR ROAD GROVE \& NURSERY \\
\hline River Citrus Co. & QUALITY FRUIT PACKERS OF INDIAN RIVER, INC, \\
\hline DONNIE SELPH FRUIT COMPANY / DBA: The Citrus & RALPH BUTLER PRODUCE, INC. / DBA: S \& L Fruit \\
\hline Store & Stand \\
\hline DOOLEY GROVES, INC. & REED'S FRUIT CO. \\
\hline DUDA BURG SUNRISE, LTD. & RICHARD'S RESTAURANTS, INC. / DBA: Bearcreek \\
\hline DUNDEE CITRUS GROWERS ASSOCIATION & Farms \\
\hline E.J. GRAHAM GROVES & RICHARDSON GROVES \\
\hline EAGLES NEST GROVE & RIDGE ISLAND GROVES \\
\hline EARRING POINT GROVES, INC. / DBA: Orchid Island & RIDGEWOOD GROVES OF PALM BEACH, INC. \\
\hline Growers & RIO CITRUS \\
\hline EAST COAST PACKERS, INC. & RIO INDIO FRUIT COMPANY \\
\hline EMERALD PACKING COMPANY, INC. & RIVERFRONT GROVES, INC. \\
\hline FLORIDA MASTERS PACKING, INC. & ROBINSON CITRUS, INC. \\
\hline FLYING W FARMS & S.D.L. \\
\hline FRED J. SNELL GROVES & SCHACHT, HENRY \\
\hline FRUITVILLE GROVE & SEBRING PACKING CO., INC. \\
\hline FULFORD PACKING & SELBY GROVES \& LLAMA RANCH \\
\hline FUQUA, THOMAS F. & SEMINOLE CITRUS PACKING, INC. \\
\hline G \& S PACKING COMPANY, INC. & SEVER GROVES, INC. \\
\hline
\end{tabular}


Table 29. Citrus Companies Licensed and Registered 1998-1999 Season (Cont.)

(The Florida Department of Citrus, 1999).

\begin{tabular}{|c|c|}
\hline Type of As & Company Name \\
\hline \multicolumn{2}{|c|}{ Shippers (Cont.) } \\
\hline $\begin{array}{l}\text { GOLDEN HARVEST PACKING CO., INC. } \\
\text { GOLDEN RIVER FRUIT CO. } \\
\text { GRACEWOOD FRUIT COMPANY / DBA: Belair } \\
\text { Packing House Joint Venture } \\
\text { GRAVES BROTHERS COMPANY } \\
\text { GREEN'S HOME BLOCK GROVE / DBA: Tree Fresh } \\
\text { Citrus } \\
\text { GREENE RIVER PACKING, INC. } \\
\text { H \& S CITRUS, INC. } \\
\text { H. JENNINGS ROU, INC. } \\
\text { HAINES CITY CITRUS GROWERS ASSOCIATION } \\
\text { HALE INDIAN RIVER GROVES, INC. } \\
\text { HALLUM CITRUS } \\
\text { HARBOR ISLAND CITRUS, INC. } \\
\text { HARVEY'S INDIAN RIVER GROVES, INC. / DBA: } \\
\text { HarVey'S GROVES } \\
\text { HAZELLIEF GROVES } \\
\text { HEARTLAND CITRUS, INC. } \\
\text { HELLER BROTHERS PACKING CORPORATION } \\
\text { HILLIARD GROVES, INC. } \\
\text { HOGAN \& SONS, INC. } \\
\text { HOLLIEANNA GROVES SALESROOM, INC. } \\
\text { HOLMES GROVE SERVICE, INC. } \\
\text { HORNBUCKLE PREMIUM CITRUS, INC. } \\
\text { HUNT BROTHERS COOPERATIVE } \\
\text { INDIAN RIVER EXCHANGE PACKERS, INC. } \\
\text { INDIAN RIVER PACKING CO., INC. } \\
\text { IRVIN'S GROVE } \\
\text { IVEY GROVES, LTD. } \\
\text { J \& J CITRUS, INC. } \\
\text { JACKSON INDIAN RIVER GROVES } \\
\text { JENNINGS CITRUS }\end{array}$ & $\begin{array}{l}\text { SUN AG, INC. } \\
\text { SUN GROVES, INC. } \\
\text { SUN RIVER, INC. } \\
\text { SUN VALLEY CITRUS } \\
\text { SUNGLO } \\
\text { SUNBRITE CITRUS, INC. } \\
\text { SUNBURST CITRUS COMPANY, INC. } \\
\text { SUNLITE CITRUS PACKING, INC. / DBA: Indian Bay } \\
\text { Packing Co. } \\
\text { SUNNY RIDGE CITRUS CO. } \\
\text { SUNRISE CITRUS } \\
\text { THE CITRUS PLACE } \\
\text { THE ORANGE SHOP, INC. } \\
\text { THE PACKERS OF INDIAN RIVER, LTD. } \\
\text { TRIPLE C GROVES } \\
\text { TROPICAL CITRUS SECTIONS, INC. } \\
\text { TRUEMAN, LOWELL E. } \\
\text { TUXEDO FRUIT COMPANY } \\
\text { UNITED INDIAN RIVER PACKERS, INC. } \\
\text { VERO BEACH CITRUS PACKERS, INC. } \\
\text { VOROUS, INC. / DBA: Mountain Ridge Citrus } \\
\text { Wm. G. ROE \& SONS, INC. / DBA: Blue Lake Citrus } \\
\text { ProductS } \\
\text { WALKER'S CITRUS } \\
\text { WATCHTOWER BIBLE \& TRACT SOCIETY OF } \\
\text { FLORIDA, INC. } \\
\text { WAVERLY GROWERS COOPERATIVE } \\
\text { WEST RIVER PACKING, INC. } \\
\text { WHIDDEN CITRUS \& PACKINGHOUSE, INC. } \\
\text { WHITE'S RED HILL GROVES } \\
\text { WINTER GARDEN CITRUS GROWERS ASSOCIATION }\end{array}$ \\
\hline \multicolumn{2}{|c|}{ Cooperatives } \\
\hline $\begin{array}{l}\text { CITRUS WORLD, INC. } \\
\text { DUNDEE CITRUS GROWERS ASSOCIATION } \\
\text { FLORIDA ORANGE MARKETERS, INC. } \\
\text { GOLDEN GEM GROWERS, INC. } \\
\text { HIGHLANDS GROWERS COOPERATIVE } \\
\text { HUNT BROTHERS COOPERATIVE } \\
\text { LAKE PLACID CITRUS COOPERATIVE } \\
\text { LAKE REGION PACKING ASSOCIATION } \\
\text { LAKE WALES CITRUS GROWERS ASSOCIATION } \\
\text { OSLO CITRUS GROWERS ASSOCIATION } \\
\text { PEACE RIVER PACKING COMPANY }\end{array}$ & $\begin{array}{l}\text { RIVER ONE INTERNATIONAL MARKETING, INC. } \\
\text { SEALD SWEET GROWERS, INC. } \\
\text { SOUTH LAKE APOPKA CITRUS GROWERS } \\
\text { ASSOCIATION } \\
\text { UMATILLA CITRUS GROWERS ASSOCIATION } \\
\text { U.S. AGRICULTURAL EXPORT CORPORATION } \\
\text { WAVERLY GROWERS COOPERATIVE } \\
\text { WINTER GARDEN CITRUS GROWERS ASSOCIATION } \\
\text { WINTER HAVEN CITRUS GROWERS ASSOCIATION }\end{array}$ \\
\hline
\end{tabular}

NOTE: This list does not include citrus businesses in the State of Florida that are not licensed and registered (Adapted from The Florida Department of Citrus 1999). 


\subsection{Cost Feasibility}

Economics is one of the most important aspects that prevention-of-pollution takes into account. The citrus industry spends considerable amounts of money in waste disposal. The prevention-of-pollution cost evaluation is based on three major items: implementation cost, incremental operating cost, and intangible cost (Dorse et al., 1994).

The implementation cost is paid by the company only one time and includes cost on waste stream identification, replacement of equipment if needed, installation of equipment, start-up and training for new equipment, administrative paper work, and other minor costs generated during the assessment implementation phase (Ellis, 1994).

The incremental operating cost is paid annually by the company and includes change in raw material consumption, change in maintenance requirements and operating activities, and disposal and utilities cost after using new technologies. This total amount is included in the second phase of the assessment as total operating cost (Dorsey et al., 1994). This intangible cost includes penalties and fines, future liabilities, and employees' exposure. The total annual cost is finally computed by adding total operating cost plus total intangible cost. The last phase of the cost feasibility for prevention-of-pollution assessments is payback period. The payback period is interpreted as savings that the company will generate per year after implementation of the assessment and is the implementation cost divided by total annual savings (Ellis, 1994). 
Within this industry, no major studies have been conducted to fully describe the industry and the associated pollution problems. However, this study presents data on the size of the industry and reviews the environmental problems associated with citrus production in Florida. The study focuses on two main aspects, agricultural and industrial processes involved in citrus fruit production.

The investigation considers final product characteristics, either fresh fruit or processed product, and the different types of waste that are generated at each phase of all processes until consumers get the product. The research characterizes contamination of soil, water, air, and fruit (e.g., a multimedia approach). The objectives of this thesis are the following:

1) To conduct a process inventory and a pollution prevention overview to identify prevention-of-pollution opportunities to minimize citrus waste generation evaluating processes and available waste generation information. In addition, a suggested cost analysis to be used by the citrus industry with pollution prevention studies is recommended.

2) To illustrate the application of some of the ISO-14000 methodologies and to propose a general step to implement those standards (e.g., LCA). 
Through the research, environmental aspects are discussed and approaches are proposed to recognize citrus industry waste streams and prevention-of-pollution opportunities to minimize them without affecting product integrity and quality. These conclusions will be useful in applying preventive pollution alternatives for the citrus industry as a whole process. 


\section{$5.1 \quad$ Method}

This study was performed based on literature review of government sources, industry publications, specialized books, personal interviews with agricultural experts, web research, and some other sources used to gather information. After information was collected, the study prepared descriptions on unit operations for each process and identified the contamination extent, water usage, sources of effluent and emission from each step from planting seed to shipment to market. Relevant information gathered from these sources was used in a general description of the citrus industry and to provide prevention-of-pollution alternatives and/or opportunities. Six main aspects were taken into account in this study:

1) The importance of prevention-of-pollution programs instead of end-of-pipe treatment.

2) The sensitivity of Florida aquifers to improperly disposed contamination and the importance and multiple uses of ground water by a large percentage of the state's population.

3) The importance of the role of the citrus industry to the State of Florida.

4) The risk of chemical residual levels in fruits and vegetables.

5) The concern of USEPA, FDA, and USDA on prevention-of-pollution, pollutants and chemical residues in food.

6) The high citrus agriculture activity in Florida. 


\subsection{Pollution Assessment}

A preliminary assessment of the citrus industry is proposed based on Figure 10 (Comprehensive Diagram of the Citrus Industry). This diagram was divided in 15 phases to facilitate the characterization and evaluation of industry components individually and as a whole. These phases provide a starting point to evaluate prevention-of-pollution opportunities. Systematically, while analyzing the flowchart diagram, the study identified potential changes such as equipment changes to reduce loss, procedural or process changes, packaging changes, training for awareness of loss, etc.

The study also indicates points of measurement to stimulate changes on handling and utilization of raw material (i.e., percentage loss of product at growth site; percentage loss of product at pick, pack, transport, etc.); total cost of pest control; total cost of pesticides and pesticide practices. The following sections describe and analyze the impact and/or waste generated at each one of the selected phases, per Figure 10.

\subsubsection{Phase I: Pre-harvesting}

Phase I produces the following anthropogenic impacts generated by pesticides released into the environment: 


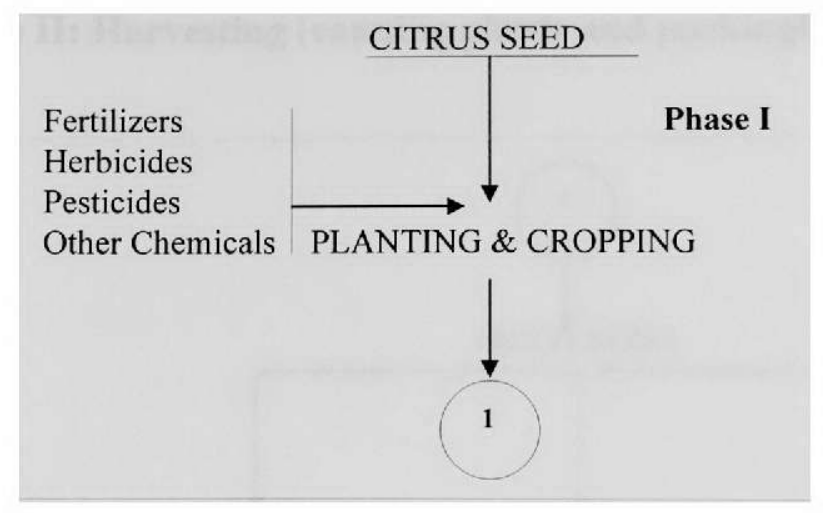

$\underline{\text { Water Media }}$

Pollution occurs by runoff and leaching of fertilizers, herbicides, insecticides, and pesticides applied during the planting and cropping activity. In addition, contamination can occur by misuse of pesticides, improper storage and disposal of empty cans.

$\underline{\text { Soil Media }}$

Soil environments are impacted as a result of applications and transport of excess chemicals by water, misuse of pesticides, and careless disposal of chemical residuals.

\section{Air Media}

Air contamination is primarily related to fumigation. Both land practices or aerial practices can produce contamination since wind can transport pesticides and contaminated soils miles away from the target area so that pollution will affect areas beyond the application location. 


\subsubsection{Phase II: Harvesting (canning plants and packinghouses)}

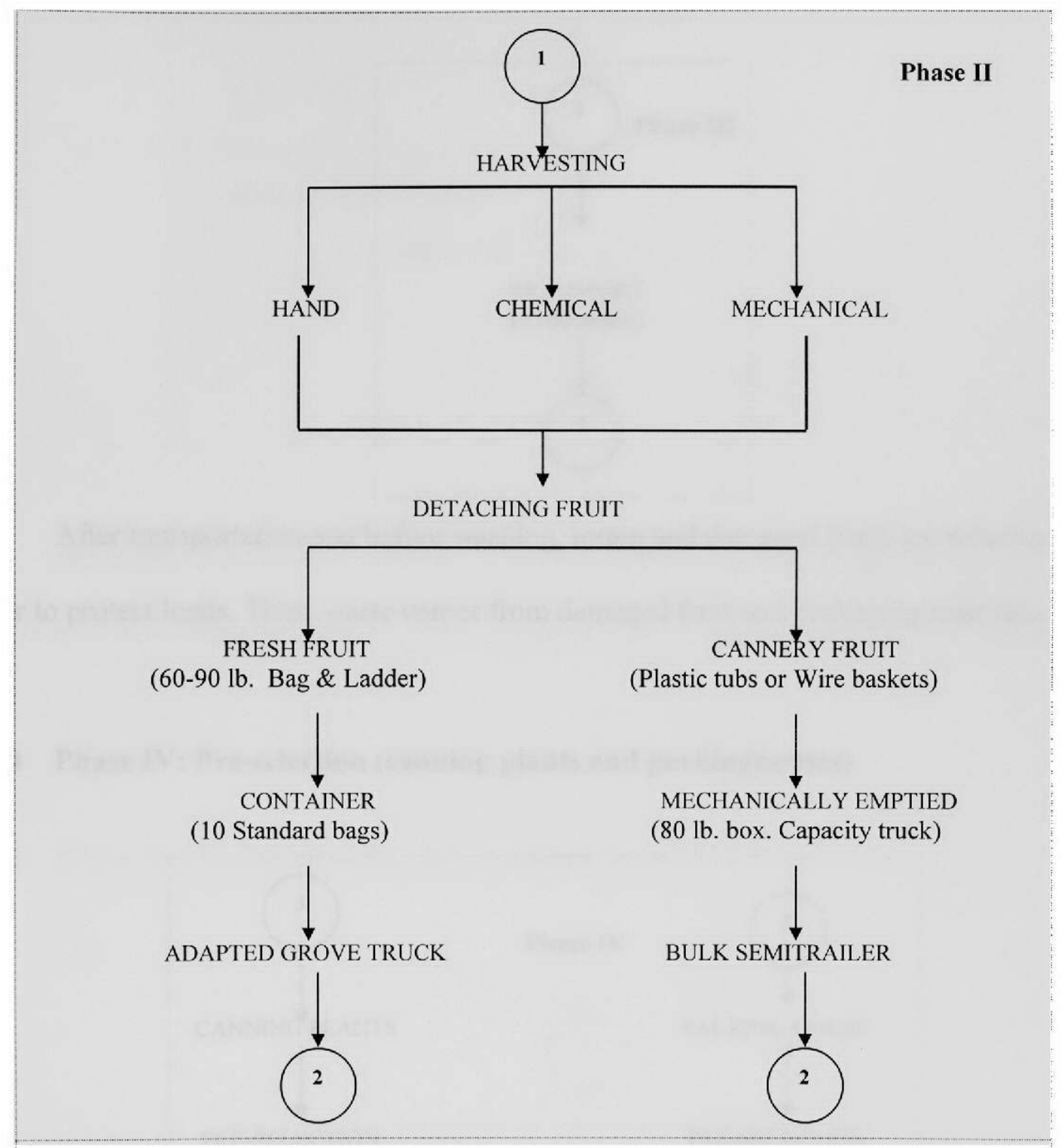

This phase covers most of the harvesting process. Solid waste contains damaged fruit, tree leaves and roots, and waste packaging. 


\subsubsection{Phase III: Transport (canning plants and packinghouses)}

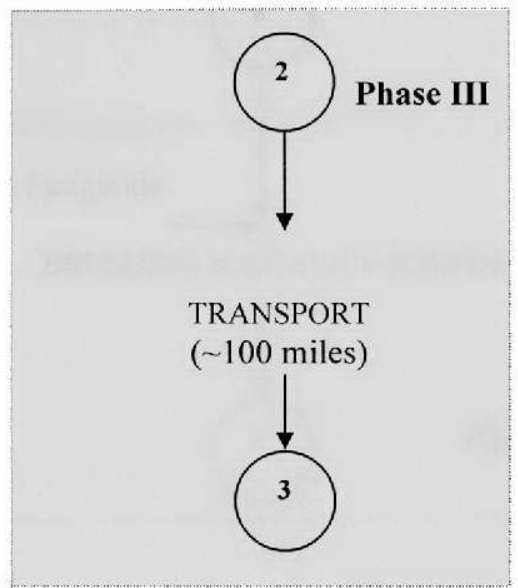

After transportation and before washing, rotten and damaged fruits are removed in order to protect loads. Thus, waste comes from damaged fruit and packaging materials.

\subsubsection{Phase IV: Pre-selection (canning plants and packinghouses)}

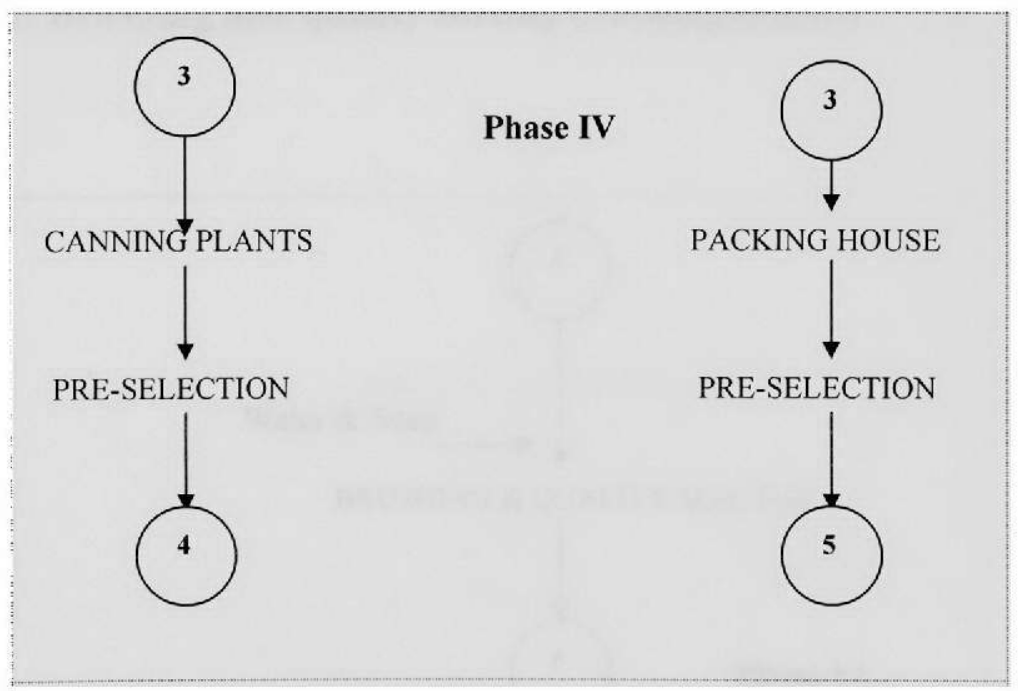

Sorting generates large quantities of solid waste results from pre-selection. 
6.1.5 Phase V: Brushing and quality sorting (canning plants)

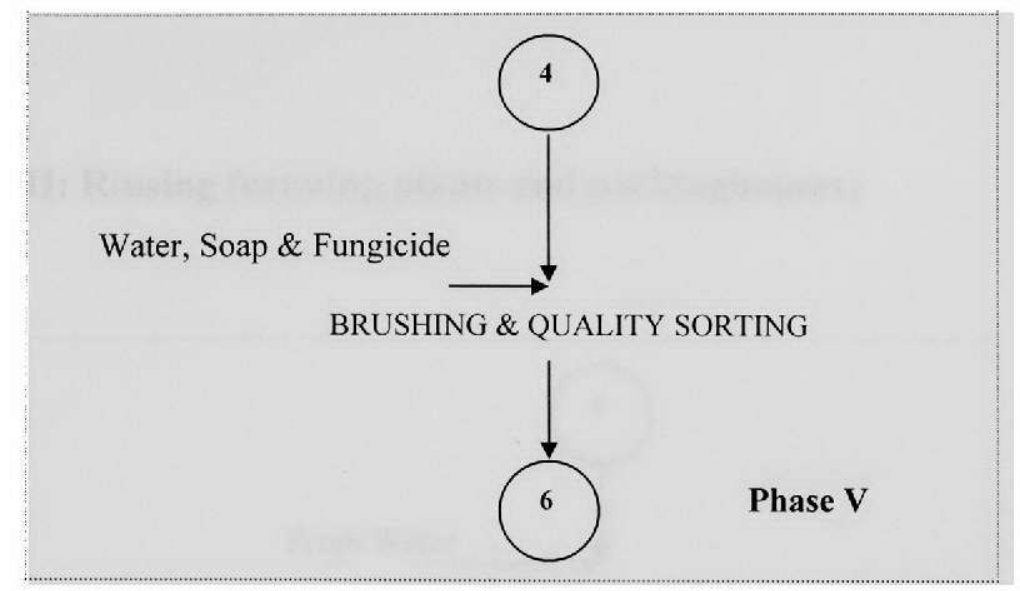

Brushing and quality sorting in canning plants produces great amounts of wastewater containing soap and fungicide residues, sand, and damaged and low quality fruit.

\subsubsection{Phase VI: Brushing and quality sorting (Packinghouses)}

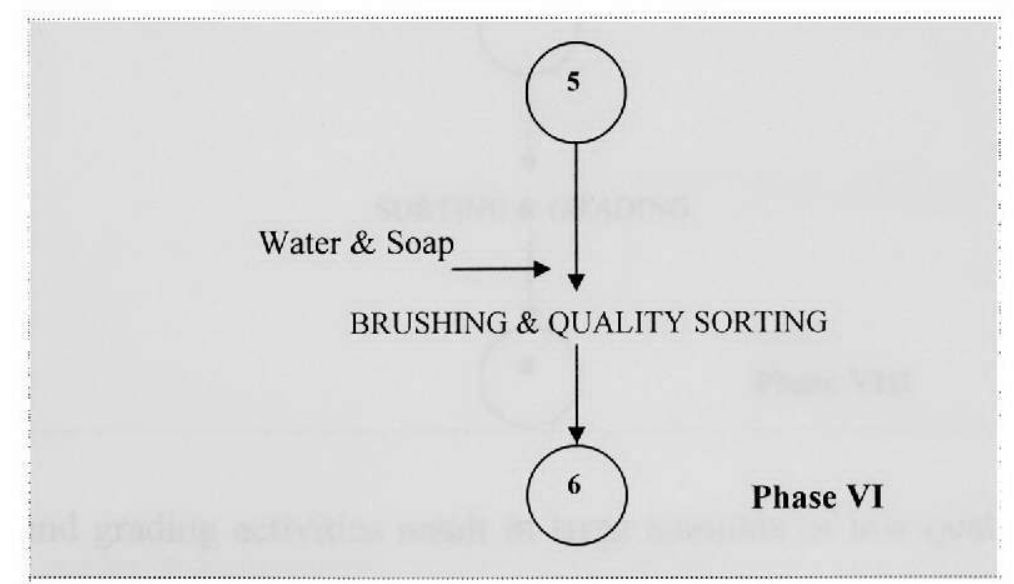


Brushing and quality sorting in packinghouses produces considerable quantity of wastewater with soap.

\subsubsection{Phase VII: Rinsing (canning plants and packinghouses)}

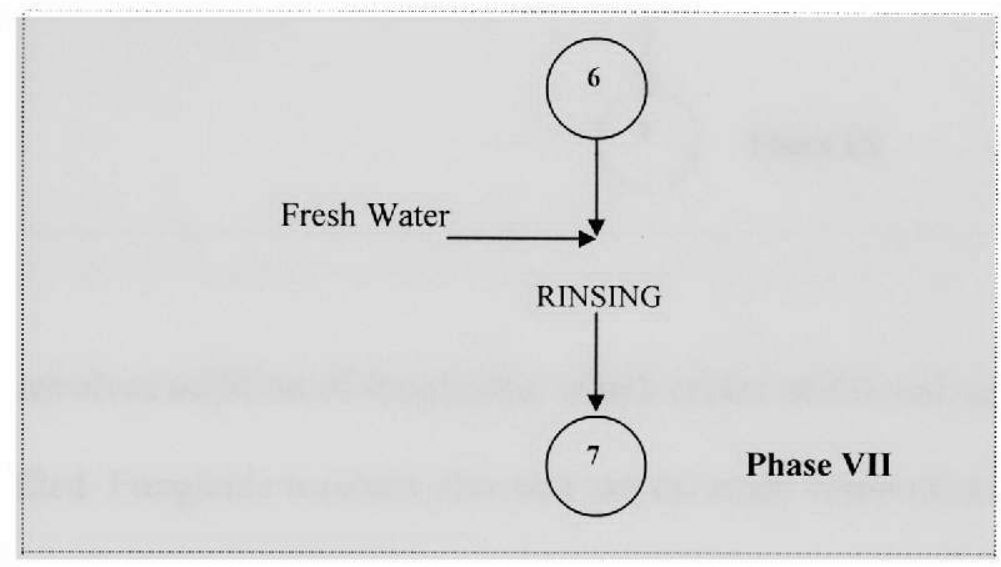

Rinsing requires fresh water, so that amount of wastewater is also large.

\subsubsection{Phase VIII: Sorting and grading (canning plants and packinghouses)}

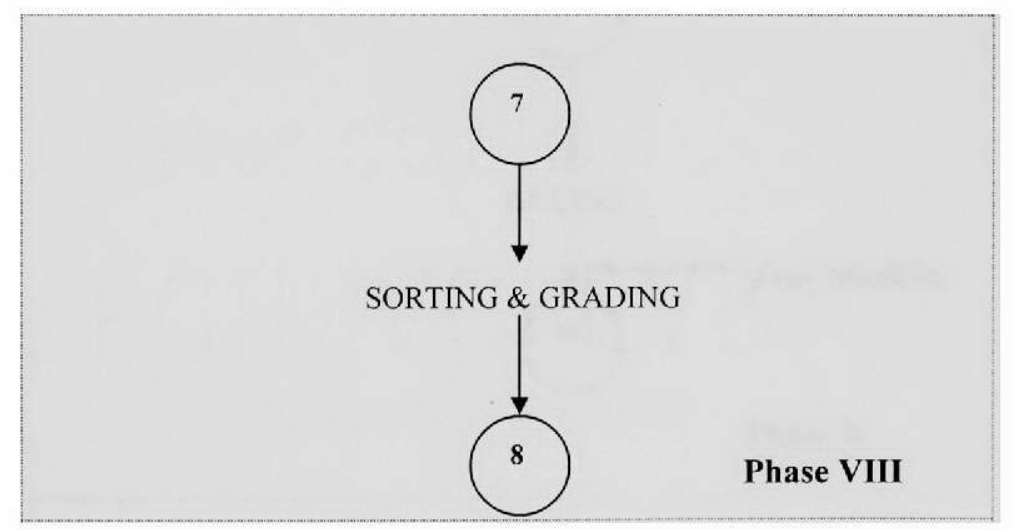

Sorting and grading activities result in large amounts of low quality fruit, which becomes solid waste. 


\subsubsection{Phase IX: Waxing (packinghouses)}

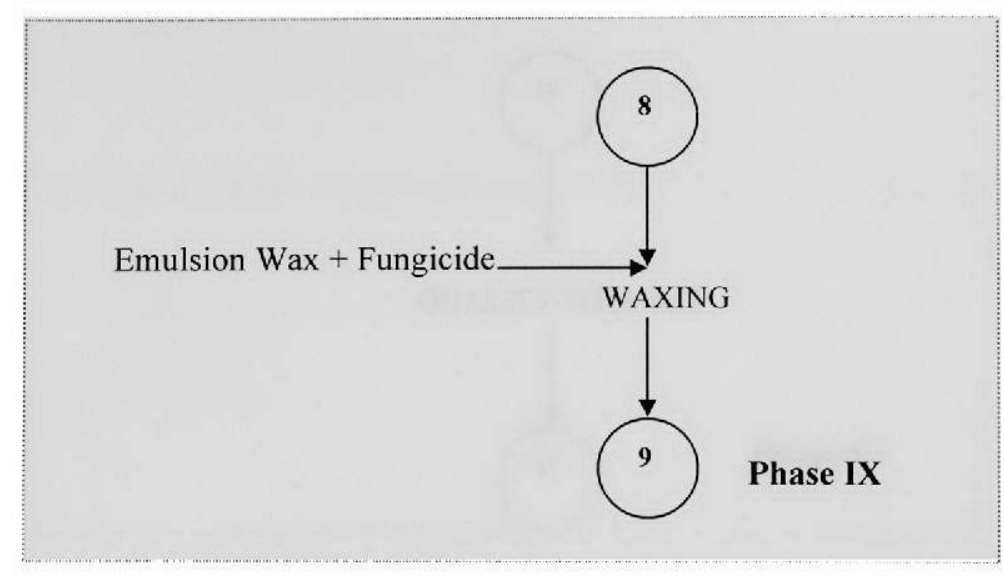

Waxing involves addition of fungicides, which create additional solid waste when not properly applied. Fungicide residues plus wax are the main components.

\subsubsection{Phase X: Drying (packinghouses)}

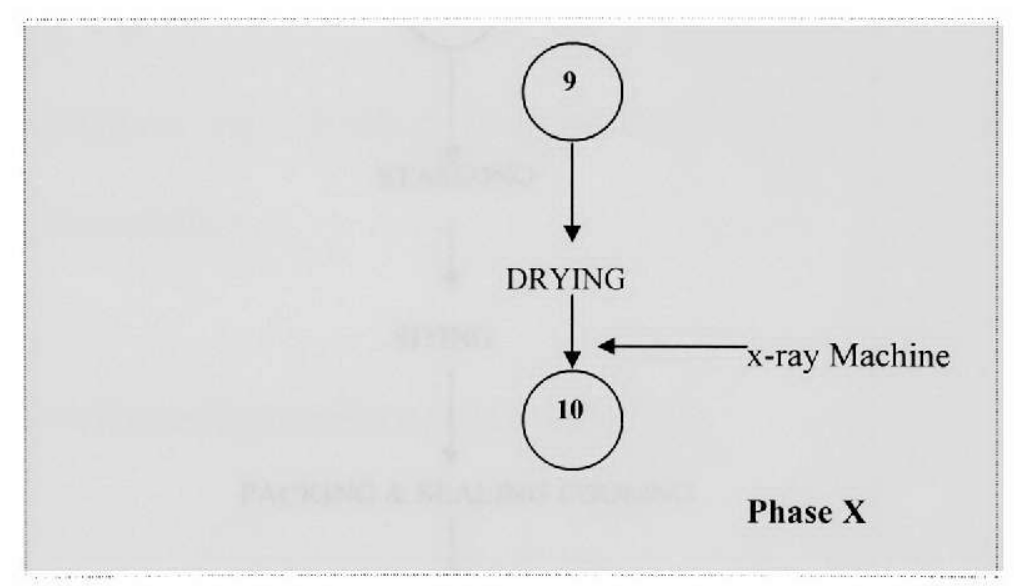

Fungicides can be released to the air during drying. 
6.1.11 Phase XI: Quality sorting (packinghouses)

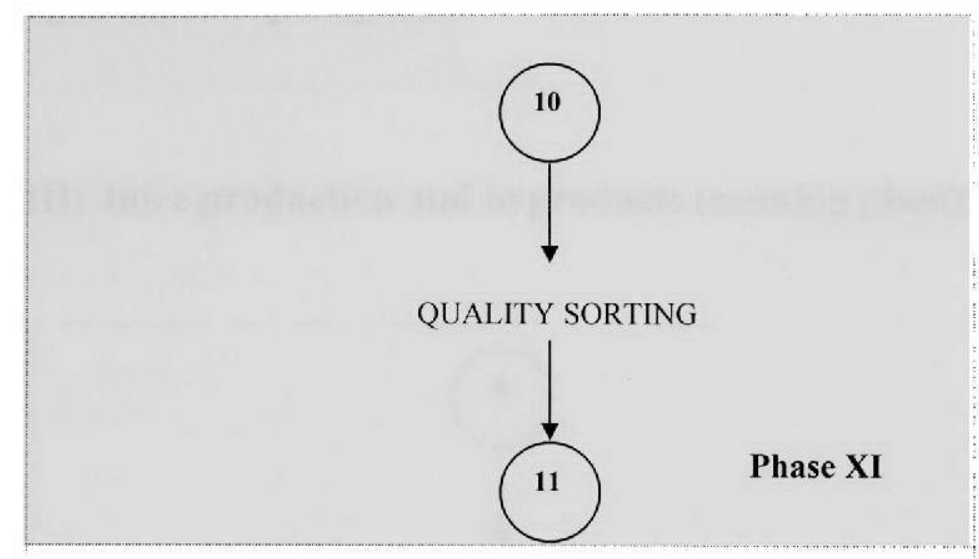

During the second quality sorting in packinghouses, the fruit is subjected to $\mathrm{x}$ rays, which can cause fruit damage (i.e., solid waste is generated).

\subsubsection{Phase XII: Packaging and related activities (packinghouses)}

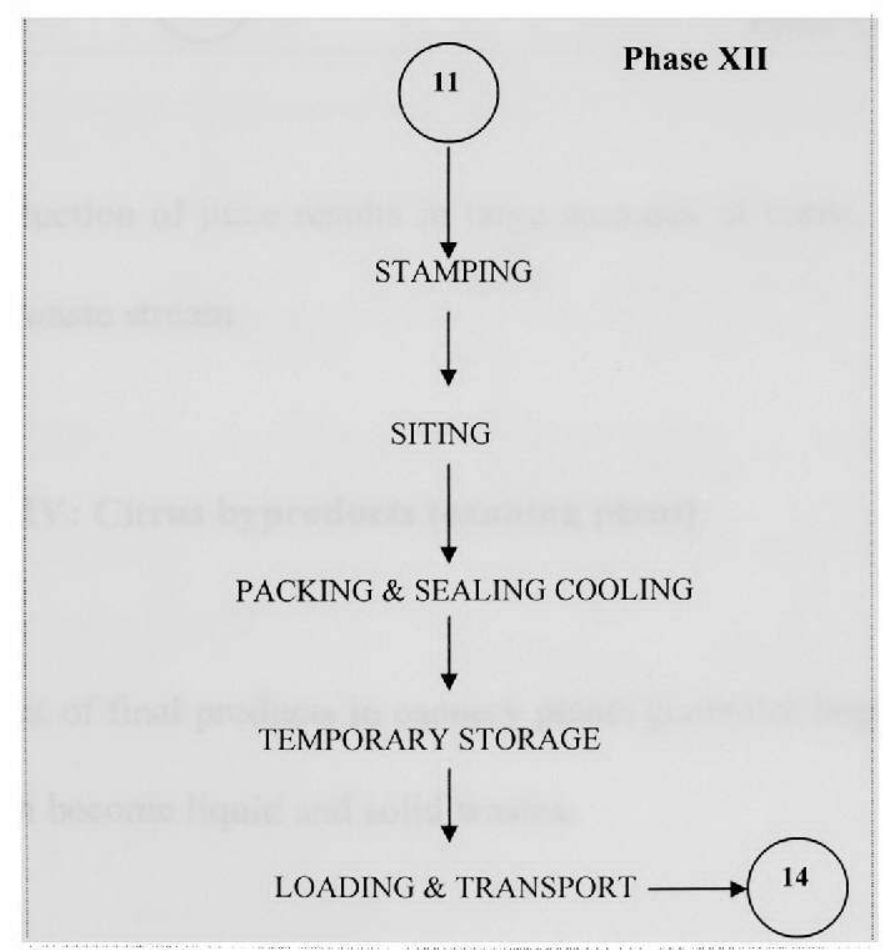


Readying fruit before marketing, sorting also results in solid waste because of the rejection of damaged and low quality fruit.

\subsubsection{Phase XIII: Juice production and byproducts (canning plant):}

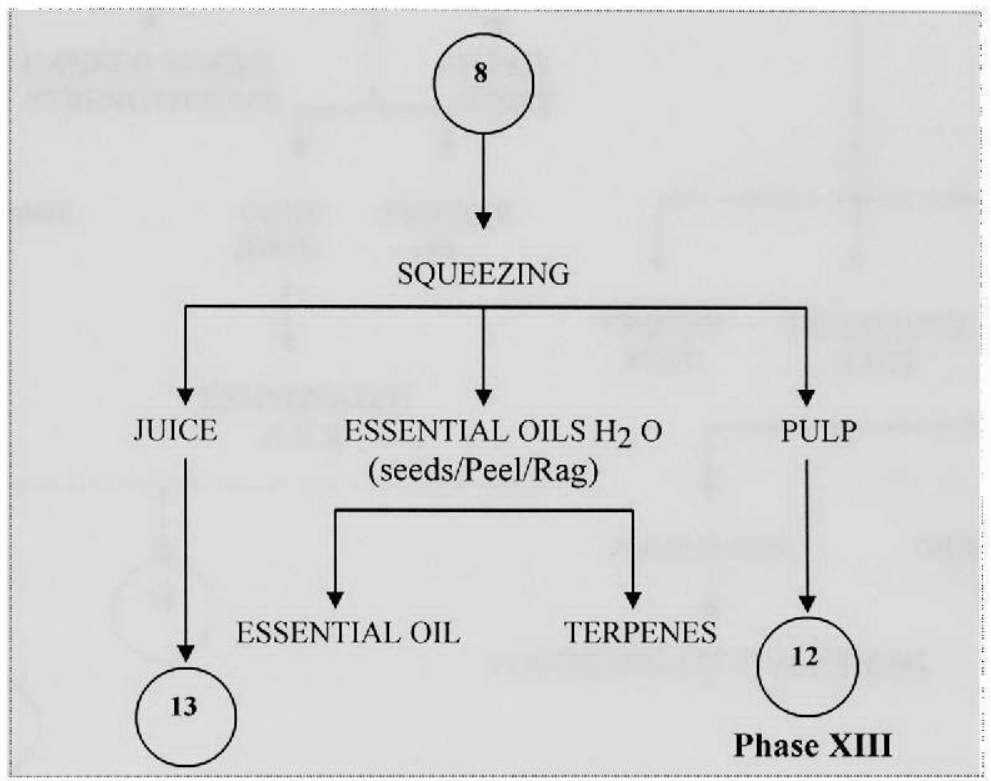

The production of juice results in large amounts of seeds, peel, and pulp, which add to the solid waste stream.

\subsubsection{Phase XIV: Citrus byproducts (canning plant)}

Treatment of final products in cannery plants generates large amounts of rags and juice sacs, which become liquid and solid wastes. 


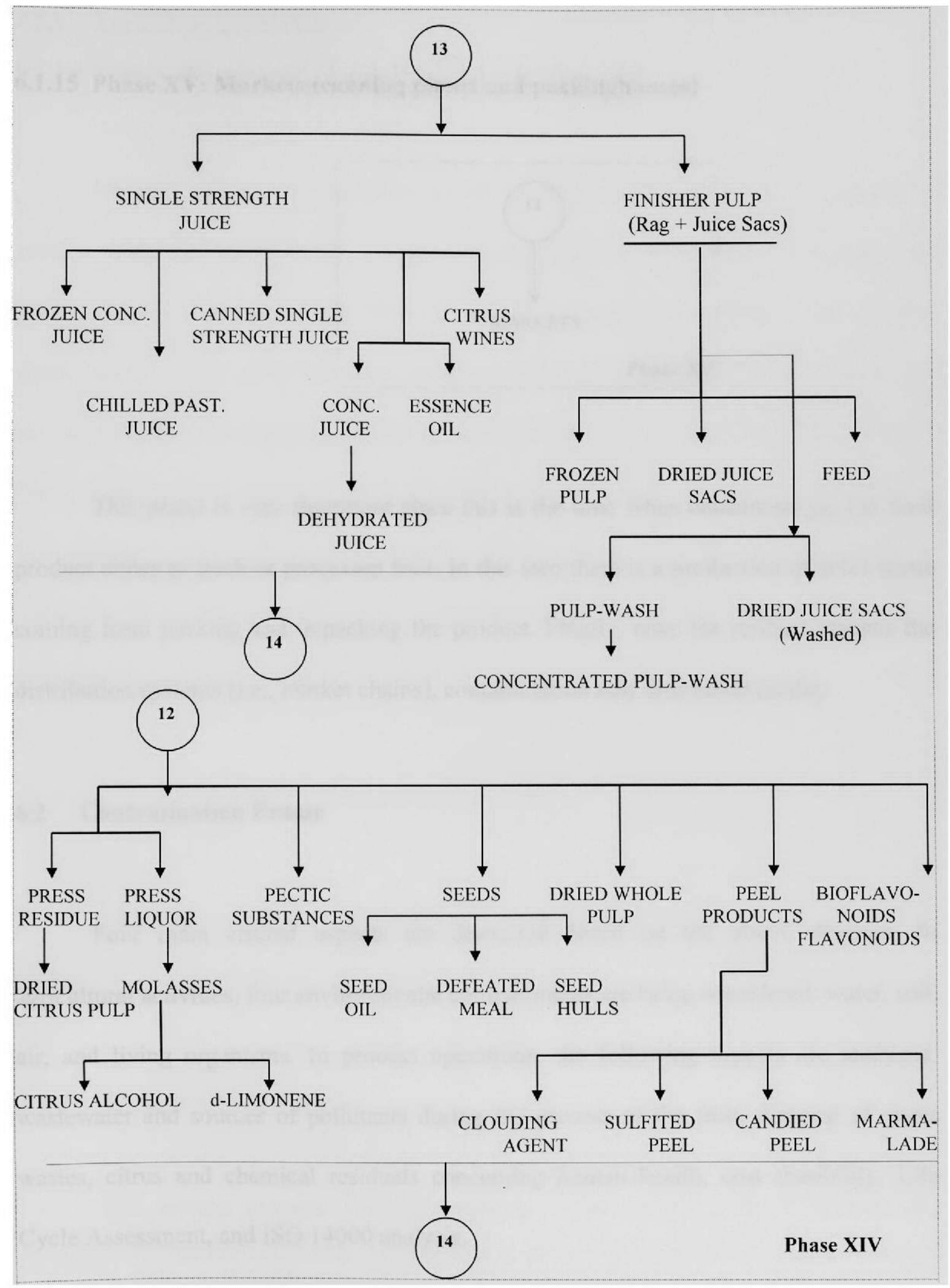




\subsubsection{Phase XV: Markets (canning plants and packinghouses)}

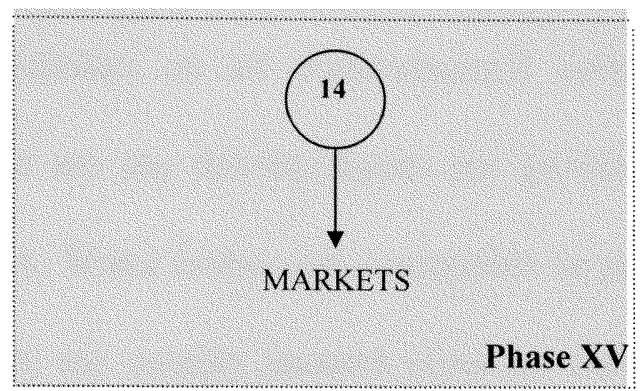

This phase is very important since this is the time when consumers get the final product either as fresh or processed fruit. In this step there is a production of solid waste coming from packing and unpacking the product. Finally, once the product reaches the distribution systems (i.e., market chains), contamination may also affect quality.

\subsection{Contamination Frame}

Four main critical aspects are discussed based on the above diagram. In agricultural activities, four environmental compartments are being considered: water, soil, air, and living organisms. In process operations, the following aspects are analyzed: wastewater and sources of pollutants during the process of the fruit, disposal of citrus wastes, citrus and chemical residuals concerning human health, cost feasibility, Life Cycle Assessment, and ISO 14000 analysis. 


\subsubsection{Agricultural Activities}

\subsubsection{Water, soil, air, and living organism compartments}

Harmful effects of pesticides on all environmental compartments especially surface water and groundwater are the driving forces for government regulators and growers to wisely use pesticides. Water bodies are susceptible to pesticide releases from citrus groves since these areas are usually located close to them. Three factors are recommended before choosing pesticides: limited mobility, decomposition, and dilution. These aspects are determined according to fate and transport of chemical compounds including properties such as water solubility (WS), octanol water (Kow), and hydrolysis. Table 20, "Adsorption coefficient for selected pesticides used in Florida citrus groves," showed WS and Kow values for different chemicals used in citrus agriculture.

\subsection{Herbicides, insecticides, and nematicides}

Quantitative data collected in Table 22 was analyzed, and results are reported for each compound in Tables 30,31 , and 32 , respectively.

\subsubsection{Effluents and Emissions}

This section presents a characterization of the various effluent streams and emissions for the citrus industry. Information is general and does not intend to represent any specific facility. 
Table 30. Herbicides, Properties, and Environmental Impact

(Ney, 1995; Hornsby and Beckers, 1991).

\begin{tabular}{|c|c|c|c|c|}
\hline Herbicide & $\begin{array}{c}\text { Ws } \\
(\mathrm{ppm})\end{array}$ & Kow & Koc & Comments \\
\hline Bromacil & 8.5 & $\mathrm{~N} / \mathrm{A}$ & 72 & $\begin{array}{l}\text { Low solubility compound. Chemical persists in any } \\
\text { environment; therefore, it is not biodegraded. } \\
\text { Bromacil may move in runoff with soil particles, } \\
\text { leaching, and be bioaccumulated according to its Koc } \\
\text { and TLC-Rf value }(0.69) \text {. This compound has been } \\
\text { detected in groundwater and may pose risks to birds, } \\
\text { reptiles, and mammals. Bromacil produces health } \\
\text { effects on pesticide handlers including thyroid, } \\
\text { adrenal, and thymus and also is classified as a possible } \\
\text { human carcinogen. }\end{array}$ \\
\hline Diuron & 42 & 94 & 400 & $\begin{array}{l}\text { The WS value indicates that the compound could be } \\
\text { present in leaching and runoff and is subject to } \\
\text { biodegradation, adsortion in soil, and } \\
\text { bioaccumulation. However, Koc, Kow, and TLC-Rf } \\
\text { values do not support WS value. Due to this reason } \\
\text { Diuron is being tested to determine exactly what is its } \\
\text { behavior when present in water and soil } \\
\text { compartments. }\end{array}$ \\
\hline Glyphosate & 12,000 & N/A & 2,640 & $\begin{array}{l}\text { Glyphosate Koc value indicates that the chemical } \\
\text { could adsorb and accumulate in soil. However, its Ws } \\
\text { value does not conclude the same observation. This } \\
\text { chemical is being tested by EPA. }\end{array}$ \\
\hline Paraquat & $1,000,000$ & N/A & $\begin{array}{c}15,47 \\
3 \\
\end{array}$ & $\begin{array}{l}\text { Its WS value predicts that the compound could leach } \\
\text { and move in runoff and bioaccumulate. }\end{array}$ \\
\hline Simazine & 135 & 155 & 135 & $\begin{array}{l}\text { Simazine WS value implies that this chemical could } \\
\text { leach and move in runoff. In addition, residues could } \\
\text { be found in the food chain. This chemical is an object } \\
\text { of discussion and research due to the high } \\
\text { concentration found in Florida water bodies. }\end{array}$ \\
\hline Terbicil & $\begin{array}{l}0.071-\mathrm{g} / 100 \mathrm{~mL} \\
\text { (a) } 25^{\circ} \mathrm{C}\end{array}$ & $\begin{array}{l}\text { Soluble } \\
\text { in water }\end{array}$ & 55 & $\begin{array}{l}\text { Terbicil could leach and move in runoff according to } \\
\text { its WS value. This chemical presents high risk } \\
\text { contaminating the aquatic compartment. It is soluble } \\
\text { in water and mobile in soil because of low adsorption. }\end{array}$ \\
\hline Trifluralin & $\begin{array}{l}0.0001-\mathrm{g} / 100 \\
\mathrm{~mL} @ 27^{\circ} \mathrm{C}\end{array}$ & $\mathrm{N} / \mathrm{A}$ & 8,000 & $\begin{array}{l}\text { Trifluralin adsorbs on organic matter. Its Ws predicts } \\
\text { that it moves in runoff with soil particles. This } \\
\text { chemical is volatile, which facilitates movement } \\
\text { contaminating other compartments besides water. } \\
\text { Adsortion, leaching, and phototransformation can } \\
\text { occur. Therefore, food chain accumulation most } \\
\text { likely happens. }\end{array}$ \\
\hline
\end{tabular}


Table 31. Insecticides, Properties, and Environmental Impact.

(Ney, 1995; Hornsby and Beckers, 1991).

\begin{tabular}{|c|c|c|c|c|}
\hline Insecticide & $\begin{array}{c}\text { Ws } \\
(p p m)\end{array}$ & Kow & Koc & Comments \\
\hline Diazinon & 42 & N/A & 1,000 & $\begin{array}{l}\text { Diazinon is a potential wildlife killer. This chemical } \\
\text { is an organo-phosphate that causes death prior to } \\
\text { bioaccumulation. However, metabolization in animal } \\
\text { could occur. Its Ws predicts that this chemical could } \\
\text { be subject to leaching, runoff, adsorption, and/or } \\
\text { bioaccumulation. }\end{array}$ \\
\hline Malathion & 45 & 780 & 780 & $\begin{array}{l}\text { Malathion is highly toxic and has caused death } \\
\text { according to an EPA study conducted in 1990, } \\
\text { "Nonoccupational Pesticide Exposure Study." Its WS } \\
\text { and Kow values indicate that it could be subject to } \\
\text { leaching, move in runoff, adsorption to soil, and } \\
\text { bioaccumulation. }\end{array}$ \\
\hline Parathion & 24 & 4,800 & 6,400 & $\begin{array}{l}\text { Parathion's Koc value predicts adverse effects and } \\
\text { possible death in mammals. Its Ws and Kow values } \\
\text { predict that this chemical could adsorb in soil, run off } \\
\text { with soil, and bioaccumulate. }\end{array}$ \\
\hline Benomyl & N/A & N/A & 1,900 & $\begin{array}{l}\text { Benomyl is a potential mutagen and teratogen, which } \\
\text { cause reproductive effects in animals. This chemical } \\
\text { can degrade or break down to many chemicals } \\
\text { including methyl 2-benzimadazolecarbanate (MBC) } \\
\text { that is a potential carcinogenic. }\end{array}$ \\
\hline Captan & 104 & 785 & 224 & $\begin{array}{l}\text { Captan is a potential mutagen, teratoge, neurotoxin, } \\
\text { and fenotoxin hazardous to animal life. This chemical } \\
\text { may break into thalidomide that causes fetal } \\
\text { abnormalities. Captan WS suggests that this } \\
\text { compound could leach, move in runoff, adsorb in soil, } \\
\text { and accumulate in soil and food chains. }\end{array}$ \\
\hline Diphenyl & 7.5 & 7,540 & 224 & $\begin{array}{l}\text { Diphenyl or biphenyl is a carcinogen and causes } \\
\text { central nervous system depression (CNS-dep). This } \\
\text { chemical could absorb to soil, move in runoff with } \\
\text { soil, and bioaccumulate. }\end{array}$ \\
\hline Thiabendazole & $<50$ & 2,104 & 1,720 & $\begin{array}{l}\text { Thiabendazole (MBC) Koc value suggests that this } \\
\text { compound is a potential teratogen and mutagen. It } \\
\text { causes reproduction hazards in wildlife. Its WS } \\
\text { suggests that this chemical could leach, move in } \\
\text { runoff, adsorb to soil, and bioaccumulate. }\end{array}$ \\
\hline
\end{tabular}

Table 32. Nematicides, Properties, and Environmental Impact.

(Ney, 1995; Hornsby and Beckers, 1991).

\begin{tabular}{|l|c|c|c|l|}
\hline Nematicide & $\begin{array}{c}\text { Ws } \\
(\mathbf{p p m})\end{array}$ & Kow & Koc & \multicolumn{1}{c|}{ Comments } \\
\hline Aldicarb & 7,800 & 11.02 & 0.073 & $\begin{array}{l}\text { Aldicarb has leached in the past into groundwater. Its } \\
\text { Ws value suggests that it can be transported in runoff. } \\
\text { This chemical is acutely toxic to aquatic life. }\end{array}$ \\
\hline
\end{tabular}




\subsubsection{Wastewater stream}

Based on data displayed in Tables 6 and 7 (USEPA and National Canners Association) and the total fruit production during the 1997-1998 season (13,584 thousand tons of oranges plus 4,445 thousand tons of lemons, limes, tangerines, and grapefruit), wastewater stream calculations were performed and summarized in Table 33. The corresponding mass balance for wastewater stream is also included (see Figure 11, 12, and 13). Calculations were made based on the Florida production season of 1997-1998. Approximately $40 \%$ of total fruit are destined for the fresh fruit market and $60 \%$ for concentrate products and juices (about 50\% each).

Fresh citrus products involve two operations that require water utilization: spray/washing and sorting. Spray/washing and sorting operations require an average of $685 \mathrm{gal} / \mathrm{ton}$ and $315 \mathrm{gal} / \mathrm{ton}$, respectively. In the case of processed fruit (processed fruit is defined as a product extracted from harvested fresh fruit with any refinement or processing operation (e.g., juices, concentrates, and byproducts), the following figures were used: citrus concentrate processes requires an average of $2,500 \mathrm{gal} / \mathrm{ton}$. Processed fruit operations require an average of 3,000 gal/ton. In terms of wastewater streams, fresh fruit processes can generate approximately $85 \%$ of water used, citrus concentrates approximately $89 \%$, and juice production $87 \%$. 
Table 33. Total Wastewater Generated during 1997-1998 Season.

\begin{tabular}{|l|l|l|l|l|l|}
\hline \multicolumn{2}{|c|}{$\begin{array}{c}\text { Citrus Production } \\
\text { 1997-1998 } \\
\text { (ton/year) }\end{array}$} & $\begin{array}{c}\text { Wastewater } \\
\text { Generated } \\
\text { (mgal) }\end{array}$ & $\begin{array}{l}\text { Losses } \\
\text { (mgal) }\end{array}$ & $\begin{array}{c}\text { Discharged } \\
\text { Water } \\
\text { (mgal) }\end{array}$ & \multicolumn{1}{|c|}{$\begin{array}{c}\text { Recirculated or } \\
\text { Reused Water } \\
\text { (gal) }\end{array}$} \\
\hline TC & $18,029,000$ & N/A & N/A & N/A & N/A \\
\hline FF & $7,211,600$ & 7,212 & 361 & 5,823 & 1,028 \\
\hline PC & $5,408,700$ & 13,522 & 676 & & \\
\hline PJ & $5,408,700$ & 16,226 & 811 & & \\
\hline
\end{tabular}

Note: Wastewater calculations are based on total production (ton/year).

Citrus Production:

Losses: Water losses due to leaking or unattended hoses during process

N/A: Not Applicable

TC: Total Citrus Production during season 1997-1998 including lemons, limes, and grapefruit

FF: Fresh Fruit

PC: Processed Concentrate

PJ: Processed Juice

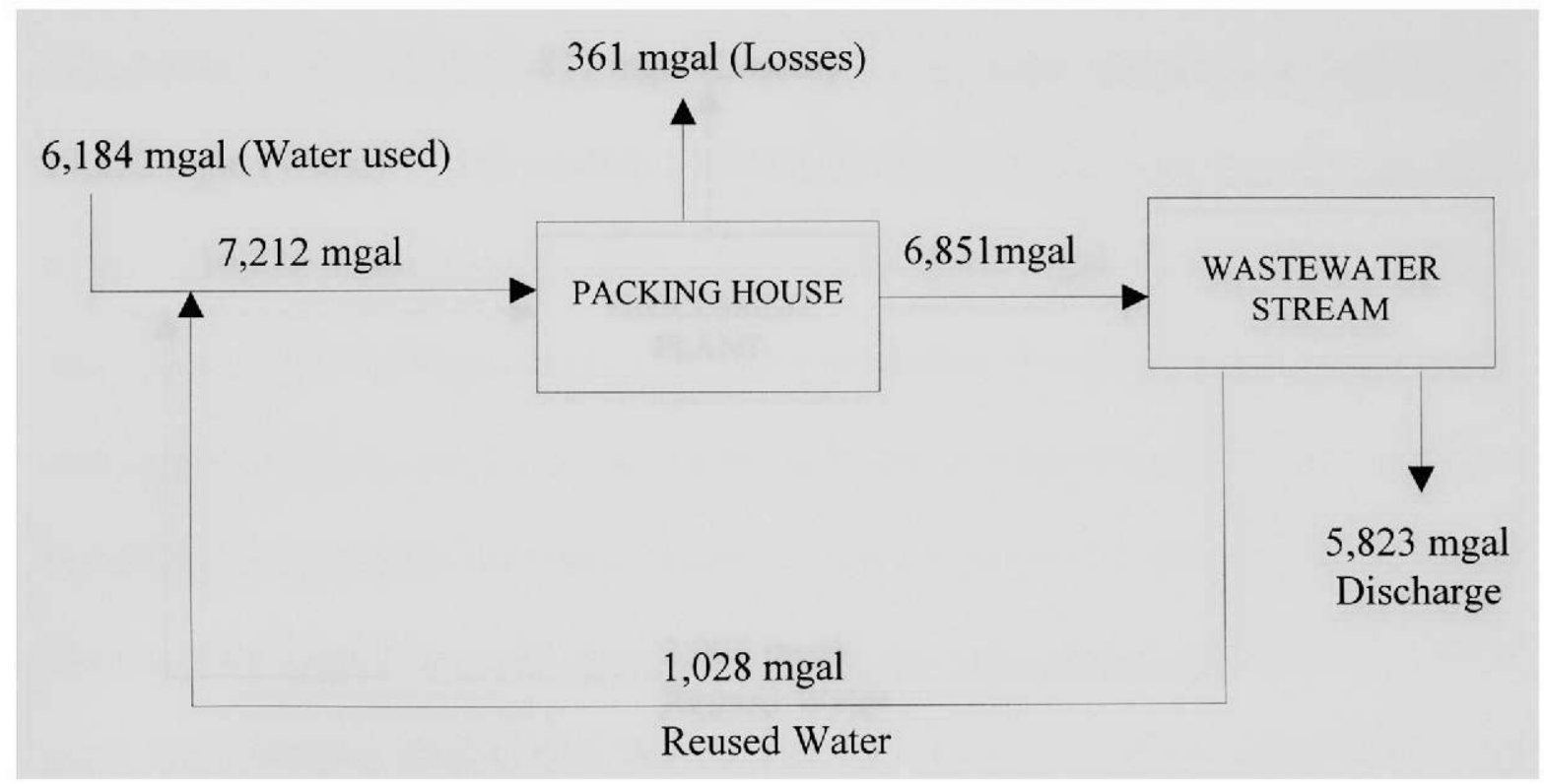

Figure 11. Mass Balance/Fresh Fruit Product

Total Fresh Fruit: 7,211,600 ton/year

Water Used: $1000 \mathrm{gal} /$ ton 


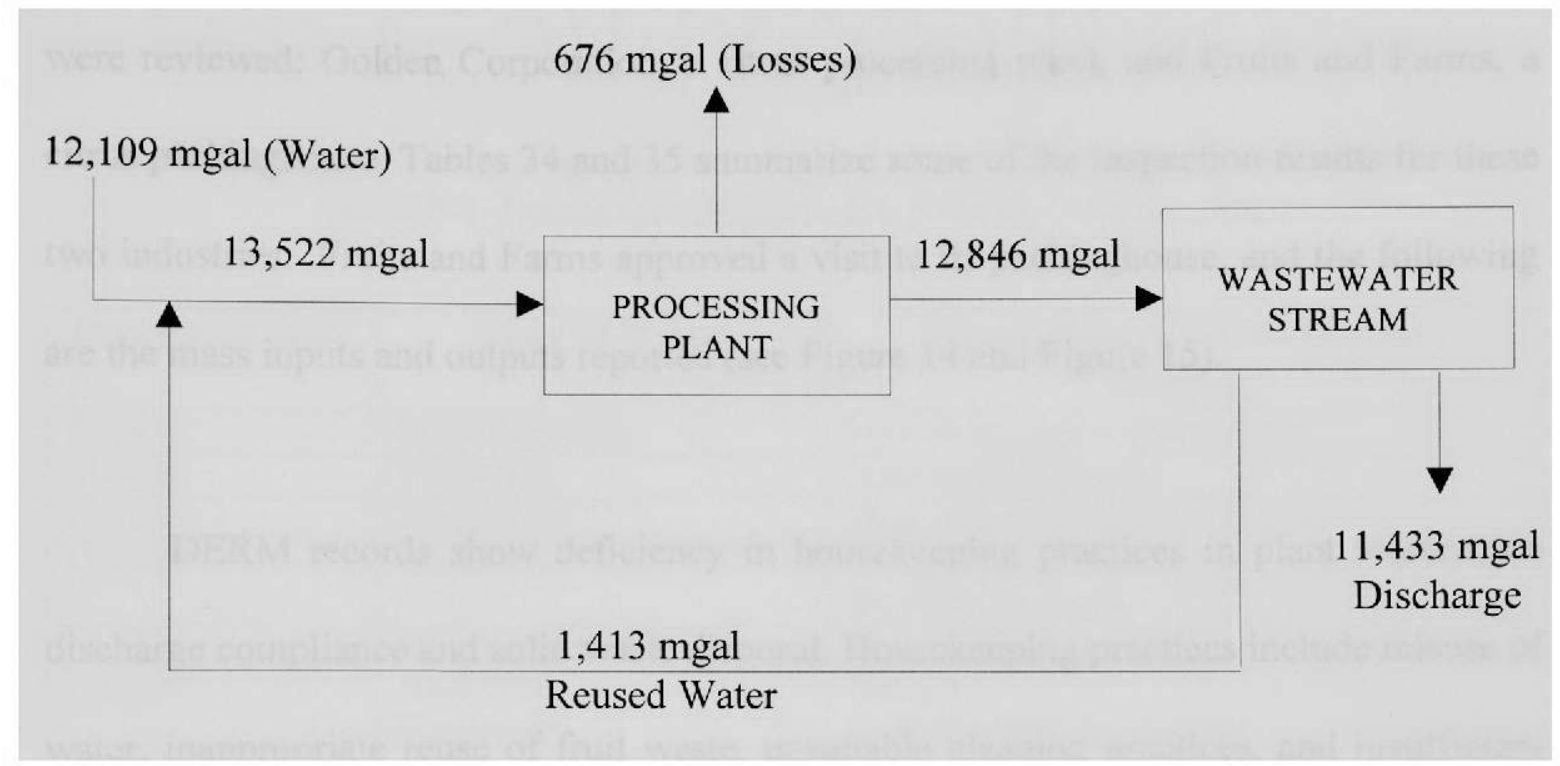

Figure 12. Mass Balance/Concentrated Product

Total Fresh Fruit: 5,408,700 ton/year

Water Used: $2,500 \mathrm{gal} / \mathrm{ton}$

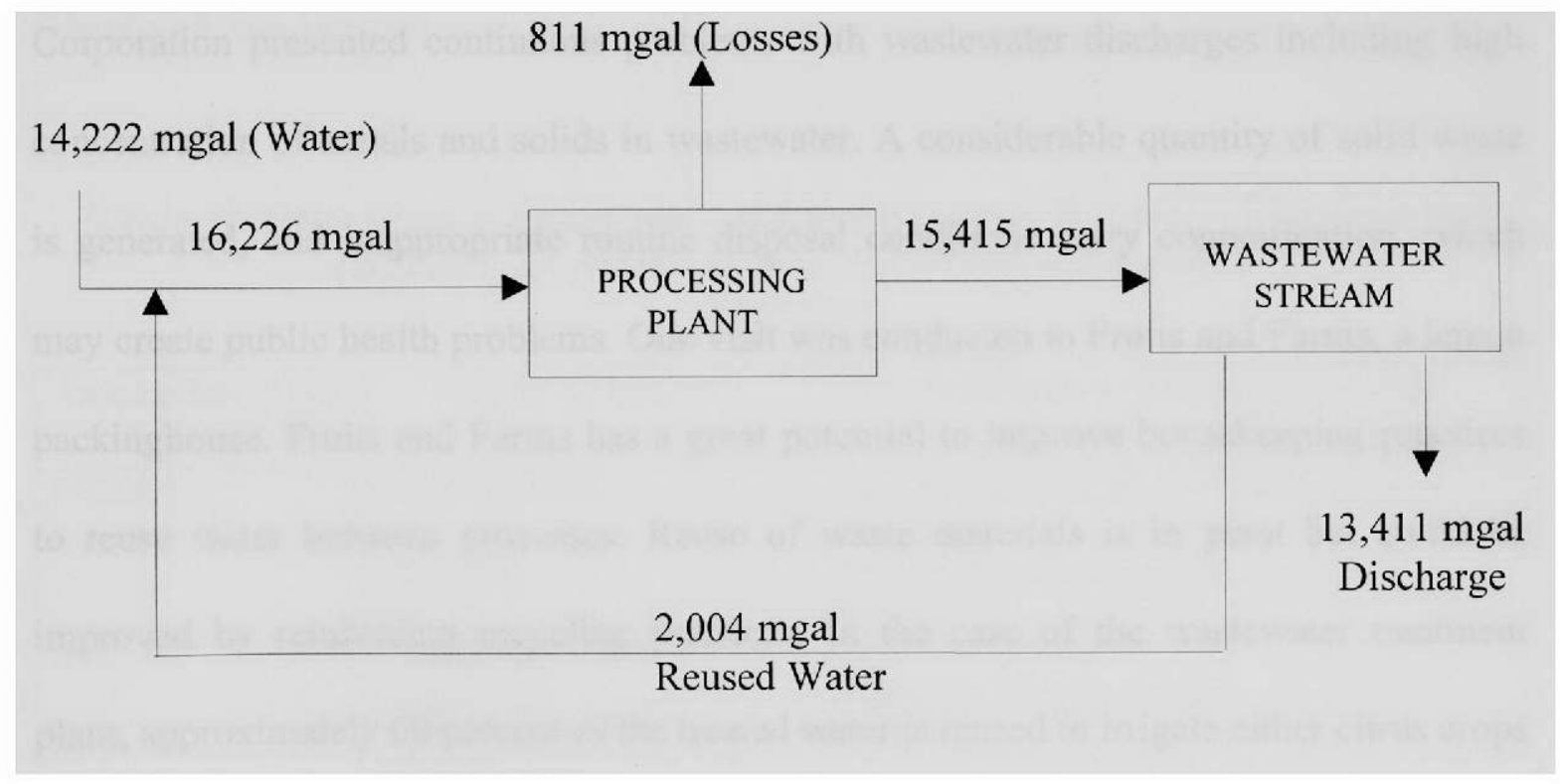

Figure 13. Mass Balance/Juice Product

Total Fresh Fruit: 5,408,700 ton/year

Water Used: $3,000 \mathrm{gal} / \mathrm{ton}$ 
To complement this study, qualitative data was collected from DERM. Two cases were reviewed: Golden Corporation, a citrus processing plant, and Fruits and Farms, a citrus packinghouse. Tables 34 and 35 summarize some of the inspection results for these two industries. Fruits and Farms approved a visit to its packinghouse, and the following are the mass inputs and outputs reported (see Figure 14 and Figure 15).

DERM records show deficiency in housekeeping practices in plant wastewater discharge compliance and solid waste disposal. Housekeeping practices include misuse of water, inappropriate reuse of fruit waste, unsuitable cleaning practices, and insufficient disposal of empty cans. Wastewater discharged to the public sewer frequently does not comply with local and state regulations. According to DERM inspection records, Golden Corporation presented continuous problems with wastewater discharges including high concentration of metals and solids in wastewater. A considerable quantity of solid waste is generated, and inappropriate routine disposal conditions carry contamination, which may create public health problems. One visit was conducted to Fruits and Farms, a lemon packinghouse. Fruits and Farms has a great potential to improve housekeeping practices to reuse water between processes. Reuse of waste materials is in plant but could be improved by reinforcing recycling practices. In the case of the wastewater treatment plant, approximately 60 percent of the treated water is reused to irrigate either citrus crops or golf courses. The following two tables summarize DERM records as per different inspections performed. 


\section{Table 34. Dade County Department of Environmental Resources Management (DERM). Inspection Reports for Golden Corporation}

(DERM, 1997).

\begin{tabular}{|l|l|l|}
\hline Inspection Date & \multicolumn{1}{|c|}{ Type of Waste } & \multicolumn{1}{|c|}{$\begin{array}{c}\text { Description of Contamination } \\
\text { Problem }\end{array}$} \\
\hline $02 / 26 / 97$ & Sewer Inspection & Poor sanitary sewer management. \\
\hline $04 / 03 / 96$ & Wastewater & Discharged to ground. \\
\hline $12 / 28 / 89$ & Wastewater & Waste stream contained vegetation. \\
\hline $12 / 22 / 89$ & Wastewater & $\begin{array}{l}\text { Wastewater does not meet sewer discharge } \\
\text { standards for metals. }\end{array}$ \\
\hline $07 / 14 / 89$ & Concentration of Copper & High concentration of copper $(0.63 \mathrm{mg} / \mathrm{L})$ \\
\hline $11 / 04 / 87$ & $\begin{array}{l}\text { Fresh Water } \\
\text { Wastewater }\end{array}$ & $\begin{array}{l}\text { Bad odor } \\
\text { Exceeding effluent standards. }\end{array}$ \\
\hline $11 / 03 / 87$ & Wastewater & Wastewater from surge tank was overflowing. \\
\hline $10 / 28 / 87$ & Wastewater & Unsatisfactory wastewater treatment. \\
\hline
\end{tabular}

Company: Golden Corporation

Type of Industry: Juice Plant

Product: Citrus Juice

Location: Goulds

Date of Visit: Not Approved

\section{Table 35. Dade County Department of Environmental Resources Management (DERM). Inspection Reports for Fruits and Farms}

(DERM, 1997).

\begin{tabular}{|c|c|c|}
\hline Inspection Date & Type of Waste & $\begin{array}{c}\text { Description of Contamination } \\
\text { Problem }\end{array}$ \\
\hline $01 / 22 / 97$ & $\begin{array}{l}\text { Waste Residues } \\
\text { Oil Spills }\end{array}$ & $\begin{array}{l}\text { Incorrect disposing of waste products (open } \\
\text { containers). } \\
\text { Oil spill from equipment and citrus oil } \\
\text { byproduct. }\end{array}$ \\
\hline $04 / 01 / 96$ & $\begin{array}{l}\text { Wastewater } \\
\text { Equipment }\end{array}$ & $\begin{array}{l}\text { Asphalt discharges } \\
\text { Valves needed to be changed. }\end{array}$ \\
\hline $10 / 13 / 95$ & Rinse Water & Cloud rinse water. \\
\hline $08 / 18 / 94$ & Equipment & Pipes needed to be fixed or changed. \\
\hline
\end{tabular}

Company: Fruits \& Farms

Type of Industry: Growing Crops Organically and Packaging House

Product: Lime

Location: Homestead

Date of Visit: $\quad 09 / 23 / 97$ 


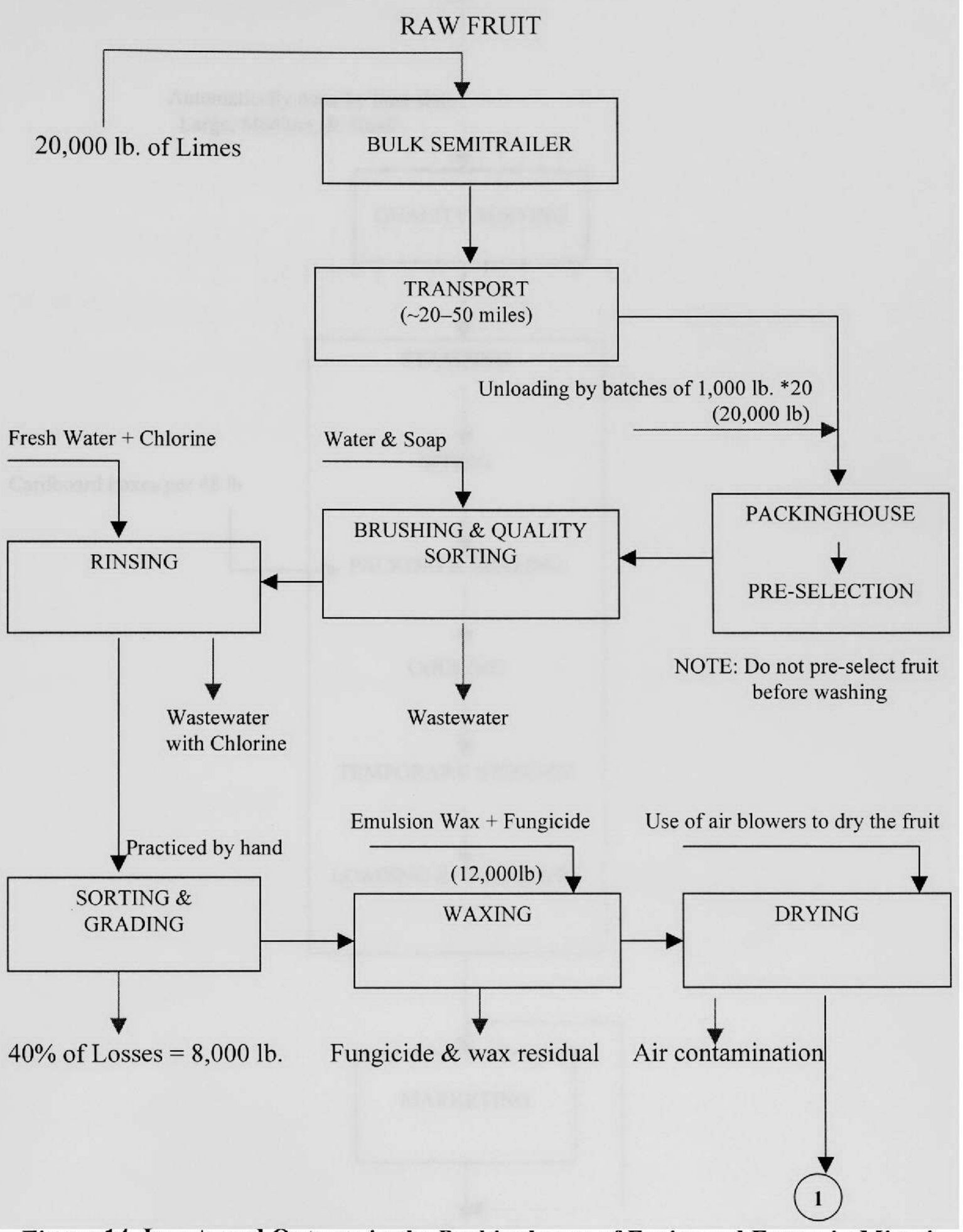

Figure 14. Inputs and Outputs in the Packinghouse of Fruits and Farms in Miami, Florida. 


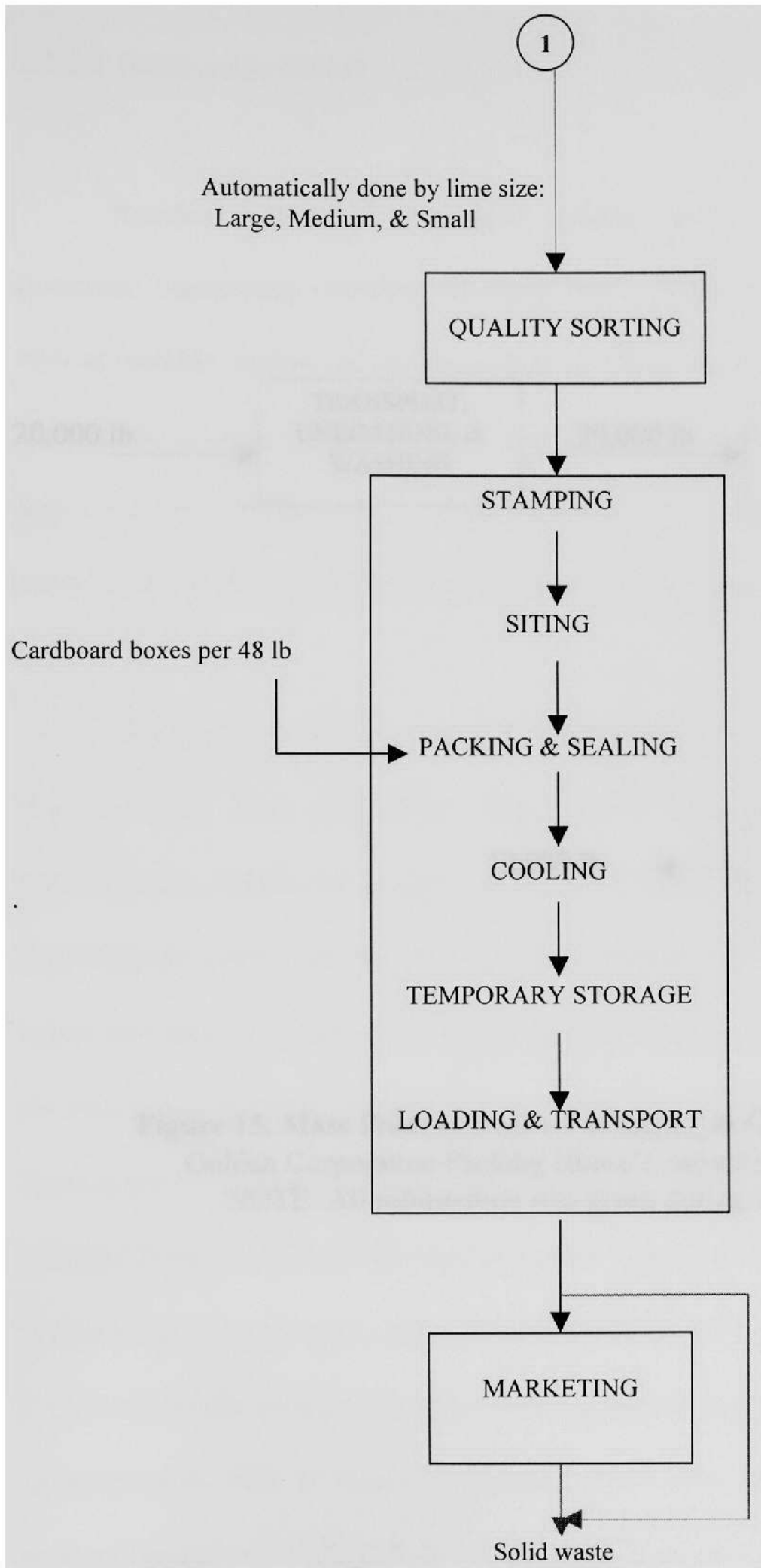

Figure 14. Inputs and Outputs in the Packinghouse of Fruits \& Farms in Miami, Florida (Cont.). 


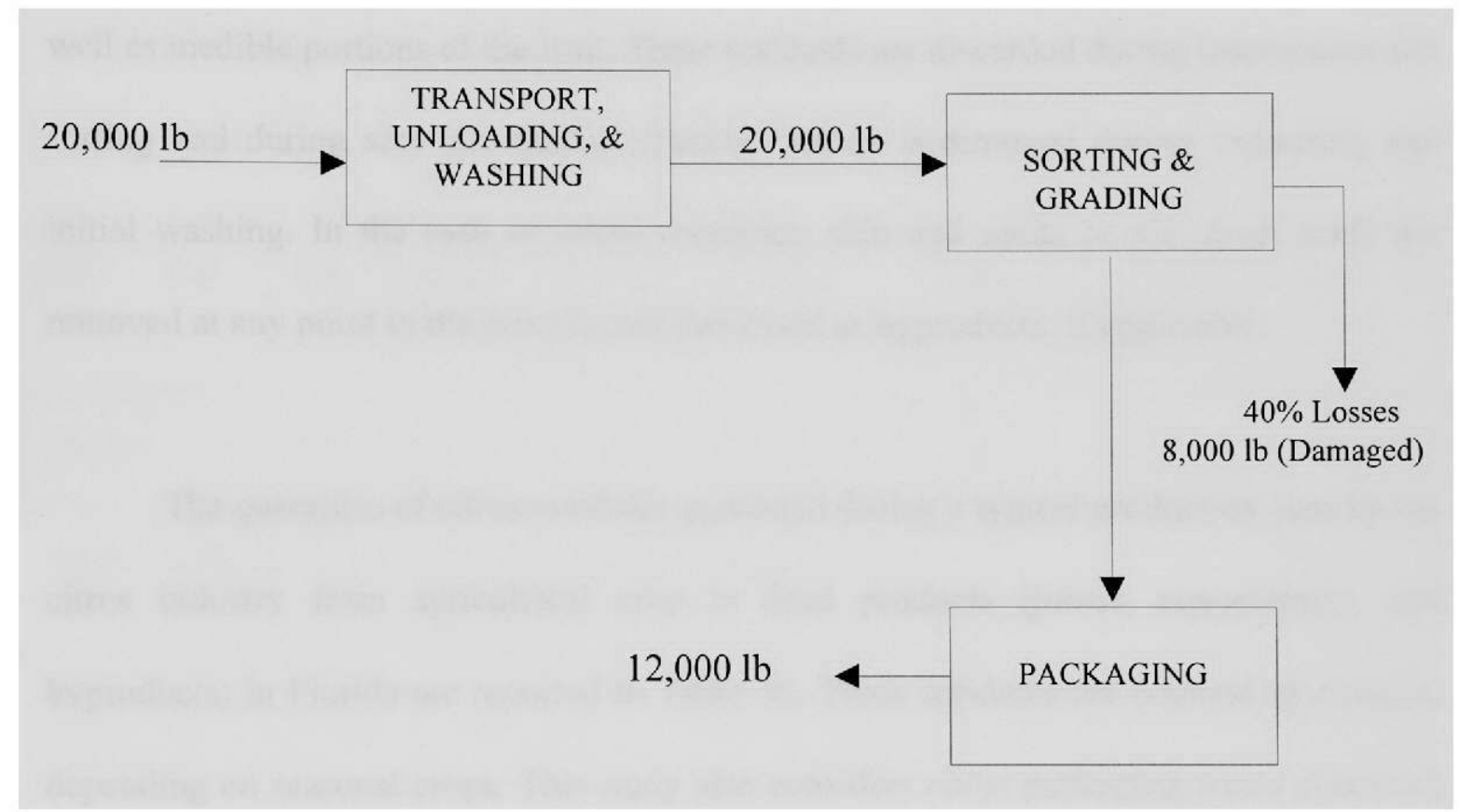

Figure 15. Mass Balance/Limes Packaging in Golden Corporation.

Golden Corporation Packing House's capacity is $20,000 \mathrm{lb} /$ day NOTE: All information was given during visit 09/23/97. 


\subsubsection{Solid waste stream}

Residual material in the citrus industry includes culls (immature, under or oversized, blemished), overripe, damaged units, extraneous debris (leaves, dirt, pits), as well as inedible portions of the fruit. These residuals are discarded during inspections and sorting and during size and quality grading. Debris is removed during unloading and initial washing. In the case of citrus canneries, skin and seeds or pits from fruits are removed at any point in the process and processed as byproducts, if applicable.

The quantities of citrus residuals generated during a typical production year by the citrus industry from agricultural crop to final products (juices, concentrates, and byproducts) in Florida are reported in Table 36 . These residuals are counted by months, depending on seasonal crops. This study also considers citrus packaging waste generated before and after processing, including empty packaging waste after consumer consumes the final product. For any food industry, including citrus, packaging waste constitutes approximately $32 \%$ of solid waste (see Figure 16 ). The solid waste generated in the citrus industry fluctuates from July to November when the crop production is low. From December to June, the solid waste generated is constant. According to Table 32 , for 7,800 $\mathrm{x} 1000$ ton of raw product, the solid waste generated during process is $3,080 \times 1000$ ton. Approximately $40 \%$ of waste is generated from total raw product. Therefore, for the seasonal period of 1997-1998 the solid waste generated is calculated and displayed in Table 37. 
Table 36. Citrus Industry Solid Residual in a Seasonal Year.

Residual Waste Generated

\begin{tabular}{|l|l|l|l|l|l|l|l|}
\hline Dec. - Jun. & Jul. & Aug. & Sept. & Oct. & Nov. & Total & $\begin{array}{l}\text { Raw } \\
\text { (ton) }\end{array}$ \\
\hline $330 \times 7$ & 210 & 100 & 100 & 160 & 210 & 3,080 & 7,800 \\
\hline
\end{tabular}

NOTE: All Figures are multiplied per 1000 tons; rounded (after adding).

Table 37. Waste Generated during the Season Year 1997-1998 by the Citrus Industry.

$$
\begin{gathered}
\text { Raw Product }{ }^{1)}=18,029,000 \text { ton } \\
\text { Waste Generated }=3,425,510 \text { ton }
\end{gathered}
$$

1) Raw product includes oranges, lemons, limes, tangerines, and grapefruit. 
Final Product: $10,817,400$ ton $(60 \%)$

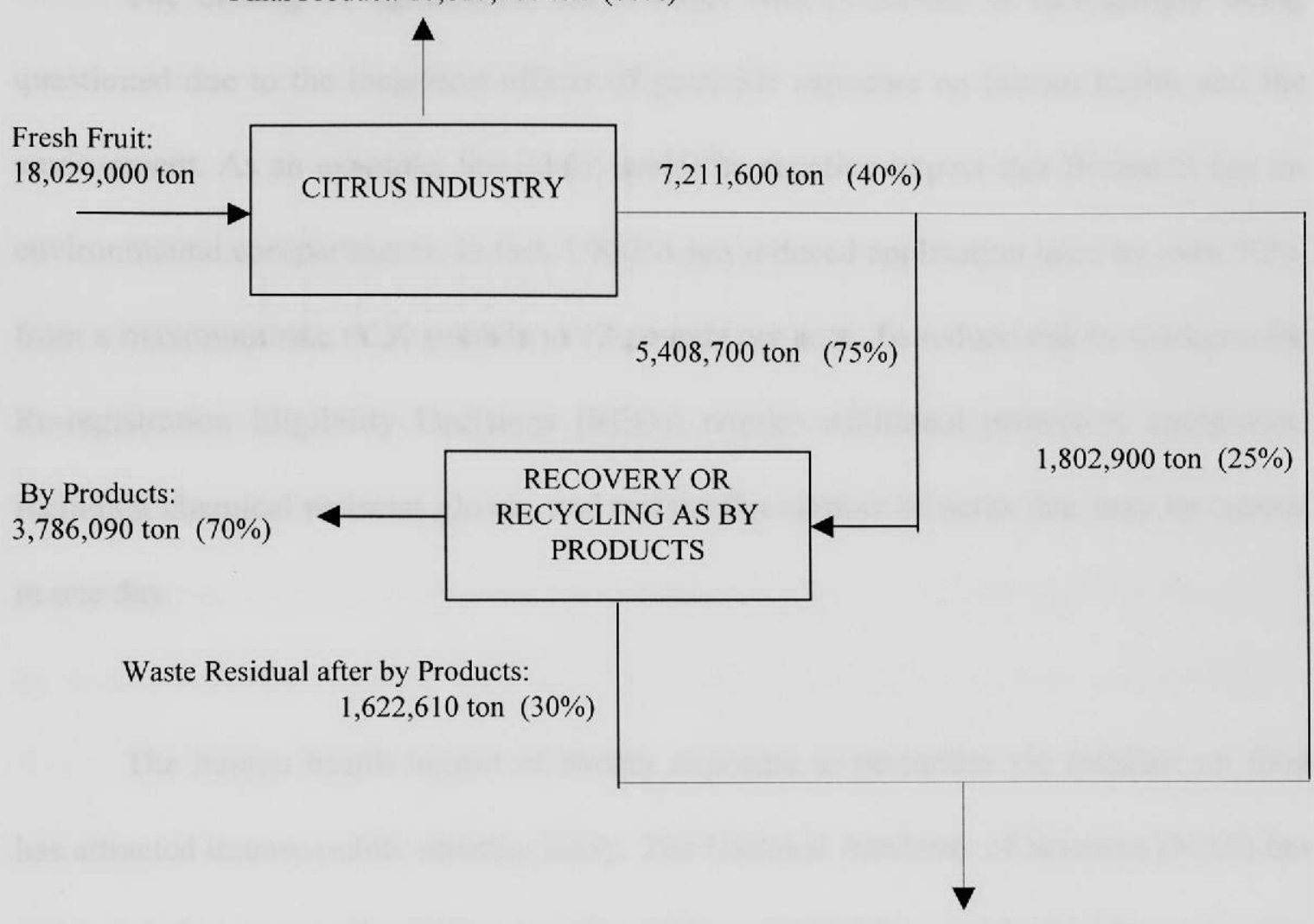

Total waste: $3,425,510$ ton

Figure 16. Mass Balance/Total Solid Waste

Based on season 1997-1998 in Florida. 


\subsubsection{Citrus, chemical residuals, and health risk}

The dusting of agricultural citrus crops with pesticides is increasingly being questioned due to the long-term effects of pesticide exposure on human health and the environment. As an example, this study noted the negative impact that Bromacil has on environmental compartments. In fact, USEPA has reduced application rates by over $50 \%$, from a maximum rate of 32 pounds to 12 pounds per acre. To reduce risk to workers, the Re-registration Eligibility Decisions (REDs) require additional protective equipment, including chemical resistant gloves, and restrict the number of acres that may be treated in one day.

The human health impact of dietary exposure to pesticides via residues on food has attracted intense public scrutiny lately. The National Academy of Sciences (NAS) has estimated that traces of carcinogenic fungicides, insecticides, and herbicides present as residuals in fruits including citrus are responsible for more than 10,000 cancer deaths per year in the United States. The Environmental Working Group, a nonprofit research organization, states that up to $35 \%$ of an individual's lifetime dose of dietary pesticide occurs before the age of 5 because children consume greater amounts of fruits than adults do.

Residuals of pesticides in fruits can cause genetic mutations, cancer, and birth defects. Toxic substances present in minute amounts in fresh fruit can thus become quite 
concentrated in the human body through time, reaching sometimes-lethal doses. This phenomenon is named chronic pesticide poisoning or low-level exposure over an extended time period. The main problem with this type of contamination is that the symptoms are vague and difficult to pinpoint.

Residual pesticides concentrate in oil glands located in the epidermis of citrus peel until saturation. In the case of fresh fruit, once oil glands are saturated, the chemical may travel through the fruit going beyond the albedo and reaching citrus pulp, which is the edible part of citrus. Looking at processing product, juices and concentrates, they may contain higher concentrations of residual chemicals since the fruit is squeezed to extract its juices, causing oil glands to break, thus liberating chemical residuals concentrated in them.

Even though fresh fruit is peeled before eating, human health risks still exist. The USEPA has established tolerance levels of fruit residue for a large number of pesticides used in agricultural activities, but additional research is continuously in development to establish specific tolerance levels for citrus fruits, which minimize injury to human health. Until USEPA does set these standards, people will keep consuming fruits containing pesticides.

After 1990, the USEPA in accordance with NAS has been testing and evaluating pesticide residues in various fruits. In the case of citrus, they have found that from 237 
orange samples tested from different regions of the United States, $80 \%$ contained one or more chemical residuals. Tolerance levels have not been published yet because the study is still in progress by the USEPA. The only data available for residual pesticides in citrus are reported as percentages of risk concentration in fresh fruit and processed product (National Research Council, 1987):

1) Fungicides: Fresh fruit $54.5 \%$ and juice and concentrates $77.8 \%$. Juice and concentrates present higher risk of fungicide residual due to the fruit squeezing process. During the squeezing process, the oil sacs contained in the peel are pressurized; thus, oil and fungicide concentrations are released.

2) Herbicides: Fresh fruit $31 \%$ and juice and concentrates $11.6 \%$.

3) Insecticides: Fresh fruit $14.5 \%$ and juice and concentrates $10.6 \%$.

\subsubsection{Life Cycle Assessment}

The primary objective of Life Cycle Assessment (LCA) is the evaluation of relevant environmental, economic, and technological aspects of a product associated with raw material, process, and final disposal after ending its life cycle. The LCA in the citrus industry is a key concept, which target products, processes, and services including stages such as agricultural activities, harvesting and processing raw materials, manufacturing, transportation and distribution, use/reuse, and recycling and waste management. 
All of the above stages have direct impact on environmental and economic issues. Learning how to manage the life cycle concept helps industry to make decisions about environmental design and improvement. It also can be used as an engineering tool for gathering quantitative data to inventory, weigh, and rank the environmental burdens of products, processes, and services. An LCA inventory for the citrus industry is suggested in Figure 17.

Figure 17 represents the general issues in every stage of a life cycle inventory in the citrus industry. The study divides the inventory into six main stages: agriculture and harvesting; management practices and processing operations; distribution and transportation; use and reuse; recycle; and waste management. These aspects relate operation, quantity, and decisions or assumptions that need to be made to evaluate the product. The input material in this case is fresh fruit or raw material. Fresh fruit is defined as a product extracted from harvesting without any refinement or processing. While the fruit goes to the packing plant or the processing facility, intermediate materials are added to the raw material to produce final byproducts and eventually wastes.

Citrus waste streams have to be identified and characterized to successfully apply the LCA diagram. This aspect is most critical for conducting a prevention-of-pollution assessment since it provides basic data. Data on waste generation were used to prioritize actions identifying resource conservation and reducing hazardous materials. 


\section{INPUTS}

\section{OUTPUTS}

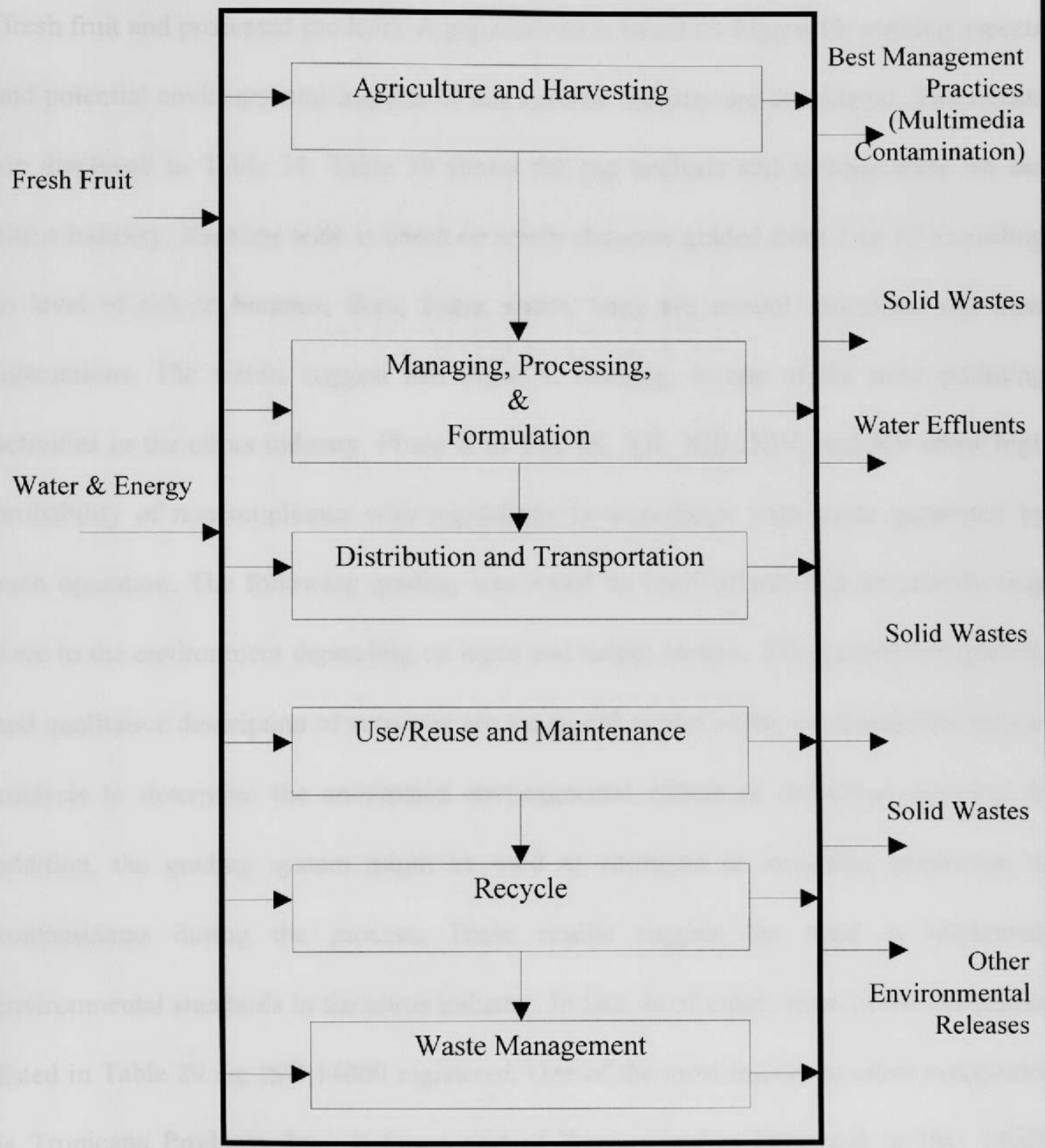

Figure 17. Suggested Life Cycle Assessment Inventory for the Citrus Industry. 


\subsubsection{A preliminary gap analysis}

This study presents a general environmental gap analysis for the citrus industry (fresh fruit and processed product). A gap analysis is based on Figure 10; ranking aspects and potential environmental impacts of this specific industry are considered. The results are displayed in Table 38. Table 38 shows the gap analysis and ranking scale for the citrus industry. Ranking scale is based on seven elements graded from 1 to 10 according to level of risk to humans, flora, fauna, water, land, air, natural resources, and their interactions. The results suggest that Phase I, Planting, is one of the most polluting activities in the citrus industry. Phase II to VII, IX, XII, XIII, XIV, and XV show high probability of noncompliance with regulations in accordance with waste generated by each operation. The following grading was based on level of risk that an activity may have to the environment depending on input and output factors. The quantitative grading and qualitative description of activities are suggested as part of the environmental impact analysis to determine the anticipated environmental effects of the citrus industry. In addition, the grading system might be used to eliminate or minimize generation of contaminants during the process. These results suggest the need to implement environmental standards in the citrus industry. In fact, as of today, none of the companies listed in Table 29 are ISO 14000 registered. One of the most important citrus companies is Tropicana Products, Inc.; it forms part of Pepsico and is interested in ISO 14000 certification. 
Table 38. Environmental Gap Analysis and Ranking Scale of the Citrus Industry.

(Adapted to the citrus industry from Science Applications International Corporation (SAIC), 1999 and Quinn, 1997).

\begin{tabular}{|c|c|c|c|c|c|c|c|c|c|}
\hline & \multirow[t]{2}{*}{ Operation } & \multirow[t]{2}{*}{ Inputs } & \multirow[t]{2}{*}{ Outputs } & \multicolumn{2}{|c|}{ Potential Impacts } & \multirow{2}{*}{$\begin{array}{l}\text { Cost of } \\
\text { Material } \\
\text { \& Toxic } \\
\text { Rating } \\
\end{array}$} & \multirow{2}{*}{$\begin{array}{c}\text { Waste } \\
\text { Disposal } \\
\text { Cost }\end{array}$} & \multirow{2}{*}{$\begin{array}{l}\text { Probability of } \\
\text { Noncompliance } \\
\text { \& Comments }\end{array}$} & \multirow{2}{*}{$\begin{array}{l}\text { Total } \\
\text { Score }\end{array}$} \\
\hline & & & & Positive & Negative & & & & \\
\hline \multicolumn{10}{|c|}{ AGRICULTURE ACTIVITY } \\
\hline $\begin{array}{c}\text { Phase } \\
\text { I }\end{array}$ & Planting & $\begin{array}{l}\text { Seeds } \\
\text { Fertilizers } \\
\text { Herbicides } \\
\text { Insecticides } \\
\text { Nematicides }\end{array}$ & $\begin{array}{l}\begin{array}{l}\text { Empty } \\
\text { chemical } \\
\text { containers }\end{array} \\
\text { Wastewater } \\
\text { Solid waste }\end{array}$ & $\begin{array}{l}\text { Recycling } \\
\text { opportunities }\end{array}$ & $\begin{array}{l}\text { Humans } \\
\text { Flora } \\
\text { Fauna } \\
\text { Water } \\
\text { Land } \\
\text { Air } \\
\text { Natural Resources } \\
\text { Other: Their } \\
\text { interactions }\end{array}$ & $\begin{array}{l}\text { Most of } \\
\text { chemicals } \\
\text { used are } \\
\text { classified } \\
\text { as toxic } \\
\text { materials }\end{array}$ & $\begin{array}{l}\text { Containers } \\
\text { Pesticides } \\
\text { residuals } \\
\text { Wastewater } \\
\text { Packaging }\end{array}$ & $\begin{array}{l}\text { Misuse of pesticides } \\
\text { and potential spills } \\
\text { Bad management } \\
\text { practices of } \\
\text { chemical application } \\
\text { and waste disposal } \\
\text { Review disposal and } \\
\text { recycling options }\end{array}$ & \\
\hline Grading & N/A & 9 & 6 & + & 6 & 8 & 8 & 5 & 42 \\
\hline \multicolumn{10}{|c|}{ CANNING PLANTS (1) \& PACKING HOUSES (2) ACTIVITIES } \\
\hline $\begin{array}{c}\text { Phase } \\
\text { II }\end{array}$ & $\begin{array}{l}\text { Harvesting } \\
\quad(1 \& 2)\end{array}$ & $\begin{array}{l}\text { Groves with } \\
\text { different } \\
\text { pesticides } \\
\text { applications } \\
\text { Packaging } \\
\text { material } \\
\end{array}$ & $\begin{array}{l}\text { Fruit } \\
\text { Damage fruit } \\
\text { Tree leaves } \\
\text { Foliage } \\
\text { Solid waste }\end{array}$ & $\begin{array}{l}\text { High quality } \\
\text { fruit } \\
\text { Recycling } \\
\text { opportunities }\end{array}$ & $\begin{array}{l}\text { Humans } \\
\text { Natural Resources }\end{array}$ & Labor & $\begin{array}{l}\begin{array}{l}\text { Damaged } \\
\text { fruit }\end{array} \\
\text { Tree leaves } \\
\text { Solid waste }\end{array}$ & $\begin{array}{l}\text { Inappropriate fresh } \\
\text { fruit and waste } \\
\text { handling } \\
\text { Review disposal, } \\
\text { reuse, and recycling } \\
\text { options }\end{array}$ & \\
\hline Grading ${ }^{1)}$ & $\mathrm{N} / \mathrm{A}$ & & 5 & + & 4 & 7 & 6 & 5 & 37 \\
\hline
\end{tabular}


Table 38. Environmental Gap Analysis and Ranking Scale of the Citrus Industry (Cont.)

(Adapted to the citrus industry from Science Applications International Corporation (SAIC), 1999 and Quinn, 1997).

\begin{tabular}{|c|c|c|c|c|c|c|c|c|c|}
\hline & \multirow[t]{2}{*}{ Operation } & \multirow[t]{2}{*}{ Inputs } & \multirow[t]{2}{*}{ Outputs } & \multicolumn{2}{|c|}{ Potential Impacts } & \multirow{2}{*}{$\begin{array}{l}\text { Cost of } \\
\text { Material } \\
\text { \& Toxic } \\
\text { Rating }\end{array}$} & \multirow{2}{*}{$\begin{array}{c}\text { Waste } \\
\text { Disposal } \\
\text { Cost }\end{array}$} & \multirow{2}{*}{$\begin{array}{c}\text { Probability of } \\
\text { Noncompliance } \\
\text { \& Comments }\end{array}$} & \multirow{2}{*}{$\begin{array}{l}\text { Total } \\
\text { Score }\end{array}$} \\
\hline & & & & Positive & Negative & & & & \\
\hline Phase III & $\begin{array}{l}\text { Transport } \\
(1 \& 2)\end{array}$ & $\begin{array}{l}\text { Fruit and } \\
\text { Packaging } \\
\text { Combustible } \\
\text { for truck }\end{array}$ & $\begin{array}{l}\text { Fruit } \\
\text { Damaged fruit } \\
\text { Packaging } \\
\text { materials } \\
\text { Media } \\
\text { contamination }\end{array}$ & $\begin{array}{l}\text { Recycling } \\
\text { opportunities }\end{array}$ & $\begin{array}{l}\text { Humans } \\
\text { Air } \\
\text { Natural resources }\end{array}$ & $\begin{array}{l}\text { Labor } \\
\text { Trucks }\end{array}$ & $\begin{array}{l}\text { Damaged } \\
\text { fruit } \\
\text { Packaging } \\
\text { materials }\end{array}$ & $\begin{array}{l}\text { Low production of } \\
\text { byproducts with } \\
\text { damaged fruit } \\
\text { Review disposal, } \\
\text { reuse, and } \\
\text { recycling options }\end{array}$ & \\
\hline Grading & $\mathrm{N} / \mathrm{A}$ & 5 & 5 & + & 6 & 6 & 7 & 7 & 36 \\
\hline $\begin{array}{l}\text { Phase } \\
\text { IV }\end{array}$ & $\begin{array}{l}\text { Pre-selection } \\
\quad(1 \& 2)\end{array}$ & $\begin{array}{l}\text { Fruit } \\
\text { Leaves } \\
\text { Dirty } \\
\text { Water } \\
\text { Energy }\end{array}$ & $\begin{array}{l}\text { Fruit } \\
\text { Damaged fruit } \\
\text { Leaves } \\
\text { Dirty } \\
\text { Wastewater }\end{array}$ & Selected fruit & $\begin{array}{l}\text { Humans } \\
\text { Flora } \\
\text { Fauna } \\
\text { Water } \\
\text { Other: Their } \\
\text { interactions }\end{array}$ & $\begin{array}{l}\text { Labor } \\
\text { Energy }\end{array}$ & $\begin{array}{l}\text { Damaged } \\
\text { fruit } \\
\text { Leaves } \\
\text { Dirty } \\
\text { Wastewater }\end{array}$ & $\begin{array}{l}\text { Low production of } \\
\text { byproducts with } \\
\text { damaged fruit } \\
\text { Review disposal, } \\
\text { reuse, and } \\
\text { recycling options }\end{array}$ & \\
\hline Grading & $\mathrm{N} / \mathrm{A}$ & 5 & 6 & + & 7 & 7 & 7 & 7 & 39 \\
\hline $\begin{array}{c}\text { Phase } \\
\text { V }\end{array}$ & $\begin{array}{l}\text { Brushing \& } \\
\text { Sorting } \\
\text { (1) }\end{array}$ & $\begin{array}{l}\text { Fruit } \\
\text { Water } \\
\text { Soap } \\
\text { Energy }\end{array}$ & $\begin{array}{l}\text { Fruit } \\
\text { Wastewater }\end{array}$ & $\begin{array}{l}\text { Minimization } \\
\text { of bacteria on } \\
\text { fruit surface }\end{array}$ & $\begin{array}{l}\text { Humans } \\
\text { Flora } \\
\text { Fauna } \\
\text { Water }\end{array}$ & $\begin{array}{l}\text { Labor } \\
\text { Energy } \\
\text { Soap may } \\
\text { be toxic } \\
\end{array}$ & $\begin{array}{l}\text { Soap } \\
\text { residual }\end{array}$ & $\begin{array}{l}\text { Residual bacteria } \\
\text { Review disposal, } \\
\text { reuse, and } \\
\text { recycling options } \\
\text { for wastewater }\end{array}$ & \\
\hline Grading & $\mathrm{N} / \mathrm{A}$ & 5 & 7 & + & 6 & 6 & 5 & 6 & 35 \\
\hline
\end{tabular}


Table 38. Environmental Gap Analysis and Ranking Scale of the Citrus Industry (Cont.)

(Adapted to the citrus industry from Science Applications International Corporation (SAIC), 1999 and Quinn, 1997)

\begin{tabular}{|c|c|c|c|c|c|c|c|c|c|}
\hline & \multirow[t]{2}{*}{ Operation } & \multirow[t]{2}{*}{ Inputs } & \multirow[t]{2}{*}{ Outputs } & \multicolumn{2}{|c|}{ Potential Impacts } & \multirow{2}{*}{$\begin{array}{c}\text { Cost of } \\
\text { Material } \\
\text { \& Toxic } \\
\text { Rating } \\
\end{array}$} & \multirow{2}{*}{$\begin{array}{c}\text { Waste } \\
\text { Disposal } \\
\text { Cost }\end{array}$} & \multirow{2}{*}{$\begin{array}{c}\text { Probability of } \\
\text { Non- } \\
\text { compliance \& } \\
\text { Comments }\end{array}$} & \multirow{2}{*}{$\begin{array}{l}\text { Total } \\
\text { Score }\end{array}$} \\
\hline & & & & Positive & Negative & & & & \\
\hline $\begin{array}{c}\text { Phase } \\
\text { VI }\end{array}$ & $\begin{array}{l}\text { Brushing \& } \\
\text { Sorting } \\
\text { (2) }\end{array}$ & $\begin{array}{l}\text { Fruit } \\
\text { Water } \\
\text { Soap } \\
\text { Energy }\end{array}$ & $\begin{array}{l}\text { Fruit } \\
\text { Wastewater }\end{array}$ & $\begin{array}{l}\text { Minimization } \\
\text { of bacteria on } \\
\text { fruit surface }\end{array}$ & $\begin{array}{l}\text { Humans } \\
\text { Flora } \\
\text { Fauna } \\
\text { Water }\end{array}$ & $\begin{array}{l}\text { Labor } \\
\text { Energy } \\
\text { Soap may } \\
\text { be toxic }\end{array}$ & $\begin{array}{l}\text { Soap } \\
\text { residual }\end{array}$ & $\begin{array}{l}\text { Soap doses } \\
\text { Residual } \\
\text { bacteria } \\
\text { Review } \\
\text { disposal, reuse, } \\
\text { and recycling } \\
\text { options } \\
\end{array}$ & \\
\hline Grading & $\mathrm{N} / \mathrm{A}$ & 6 & 6 & + & 6 & 7 & 5 & 5 & 35 \\
\hline $\begin{array}{l}\text { Phase } \\
\text { VII }\end{array}$ & $\begin{array}{l}\text { Rinsing } \\
(1 \& 2)\end{array}$ & $\begin{array}{l}\text { Fruit } \\
\text { Fresh water } \\
\text { Energy }\end{array}$ & $\begin{array}{l}\text { Fruit } \\
\text { Wastewater }\end{array}$ & Clean fruit & $\begin{array}{l}\text { Humans } \\
\text { Flora } \\
\text { Fauna } \\
\text { Water }\end{array}$ & $\begin{array}{l}\text { Labor } \\
\text { Wastewater } \\
\text { may be } \\
\text { toxic for } \\
\text { aquatic life }\end{array}$ & $\begin{array}{l}\text { Wastewater } \\
\text { with soap }\end{array}$ & $\begin{array}{l}\text { Review } \\
\text { disposal, reuse, } \\
\text { and recycling } \\
\text { options }\end{array}$ & \\
\hline Grading & $\mathrm{N} / \mathrm{A}$ & 5 & 5 & t & 5 & 5 & 5 & 5 & 30 \\
\hline $\begin{array}{l}\text { Phase } \\
\text { VIII }\end{array}$ & $\begin{array}{c}\text { Sorting \& } \\
\text { Grading } \\
\text { Raw Fruit } \\
(1 \& 2) \\
\end{array}$ & $\begin{array}{l}\text { Fruit } \\
\text { Energy }\end{array}$ & Fruit & $\begin{array}{l}\text { Quality } \\
\text { controlled } \\
\text { fruit }\end{array}$ & Humans & Labor & Solid waste & $\begin{array}{l}\text { Review } \\
\text { disposal, reuse, } \\
\text { and recycling } \\
\text { options } \\
\end{array}$ & \\
\hline Grading & N/A & 4 & 3 & + & 3 & 3 & 4 & 5 & 22 \\
\hline
\end{tabular}


Table 38. Environmental Gap Analysis and Ranking Scale of the Citrus Industry (Cont.)

(Adapted to the citrus industry from Science Applications International Corporation (SAIC), 1999 and Quinn, 1997).

\begin{tabular}{|c|c|c|c|c|c|c|c|c|c|}
\hline & \multirow[t]{2}{*}{ Operation } & \multirow[t]{2}{*}{ Inputs } & \multirow[t]{2}{*}{ Outputs } & \multicolumn{2}{|c|}{ Potential Impacts } & \multirow{2}{*}{$\begin{array}{c}\text { Cost of } \\
\text { Material } \\
\text { \& Toxic } \\
\text { Rating }\end{array}$} & \multirow{2}{*}{$\begin{array}{c}\text { Waste } \\
\text { Disposal } \\
\text { Cost }\end{array}$} & \multirow{2}{*}{$\begin{array}{c}\text { Probability of } \\
\text { Non- } \\
\text { compliance \& } \\
\text { Comments }\end{array}$} & \multirow{2}{*}{$\begin{array}{l}\text { Total } \\
\text { Score }\end{array}$} \\
\hline & & & & Positive & Negative & & & & \\
\hline $\begin{array}{l}\text { Phase } \\
\text { IX }\end{array}$ & $\begin{array}{c}\text { Waxing } \\
\text { (2) }\end{array}$ & $\begin{array}{l}\text { Fruit } \\
\text { Emulsion } \\
\text { Wax/ } \\
\text { Fungicide } \\
\text { Energy }\end{array}$ & $\begin{array}{l}\text { Waxed Fruit } \\
\text { Emulsion } \\
\text { residuals }\end{array}$ & $\begin{array}{l}\text { Protected } \\
\text { fruit for } \\
\text { storage } \\
\text { purposes }\end{array}$ & $\begin{array}{l}\text { Humans } \\
\text { Flora } \\
\text { Fauna } \\
\text { Water } \\
\text { Land } \\
\text { Air }\end{array}$ & $\begin{array}{l}\text { Labor } \\
\text { Wax may } \\
\text { be toxic } \\
\text { Fungicides } \\
\text { are toxic } \\
\text { substances }\end{array}$ & $\begin{array}{l}\text { Wax } \\
\text { residuals } \\
\text { Fungicides } \\
\text { residuals }\end{array}$ & $\begin{array}{l}\text { Misuse of } \\
\text { fungicides and } \\
\text { potential spills } \\
\text { Bad } \\
\text { management } \\
\text { practices of } \\
\text { chemical } \\
\text { application and } \\
\text { waste disposal }\end{array}$ & \\
\hline Grading & $\mathrm{N} / \mathrm{A}$ & 7 & 7 & + & 7 & 5 & 5 & 6 & 37 \\
\hline $\begin{array}{c}\text { Phase } \\
X\end{array}$ & $\begin{array}{l}\text { Drying } \\
\text { (2) }\end{array}$ & $\begin{array}{l}\text { Waxed fruit } \\
\text { Air } \\
\text { Energy }\end{array}$ & Dry fruit & $\mathrm{N} / \mathrm{A}$ & $\begin{array}{l}\text { Humans } \\
\text { Air }\end{array}$ & $\begin{array}{l}\text { Labor } \\
\text { Wax may } \\
\text { be toxic }\end{array}$ & $\begin{array}{l}\text { Wax } \\
\text { particles in } \\
\text { air } \\
\text { Solid waste }\end{array}$ & $\begin{array}{l}\begin{array}{l}\text { Control air } \\
\text { speed and } \\
\text { spread after } \\
\text { fruit drying }\end{array} \\
\text { Review } \\
\text { disposal, reuse, } \\
\text { and recycling } \\
\text { options } \\
\end{array}$ & \\
\hline Grading & $\mathrm{N} / \mathrm{A}$ & 5 & 3 & + & 5 & 5 & 5 & 5 & 28 \\
\hline $\begin{array}{c}\text { Phase } \\
\text { XI }\end{array}$ & $\begin{array}{c}\text { Fresh Fruit } \\
\text { Quality } \\
\text { Sorting } \\
(2) \\
\end{array}$ & $\begin{array}{l}\text { Dry waxed } \\
\text { fruit } \\
\text { Energy } \\
\end{array}$ & Sorted fruit & $\begin{array}{l}\text { Optimum } \\
\text { product }\end{array}$ & $\begin{array}{l}\text { Humans } \\
\text { Land }\end{array}$ & Labor & Solid waste & $\begin{array}{l}\text { Review } \\
\text { disposal, reuse, } \\
\text { and recycling } \\
\text { options }\end{array}$ & \\
\hline Grading & $\mathrm{N} / \mathrm{A}$ & 4 & 2 & + & 2 & 3 & 2 & 5 & 18 \\
\hline
\end{tabular}


Table 38. Environmental Gap Analysis and Ranking Scale of the Citrus Industry (Cont.)

(Adapted to the citrus industry from Science Applications International Corporation (SAIC), 1999 and Quinn, 1997).

\begin{tabular}{|c|c|c|c|c|c|c|c|c|c|}
\hline & \multirow[t]{2}{*}{ Operation } & \multirow[t]{2}{*}{ Inputs } & \multirow[t]{2}{*}{ Outputs } & \multicolumn{2}{|c|}{ Potential Impacts } & \multirow{2}{*}{$\begin{array}{c}\text { Cost of } \\
\text { Material } \\
\text { \& Toxic } \\
\text { Rating }\end{array}$} & \multirow{2}{*}{$\begin{array}{c}\text { Waste } \\
\text { Disposal } \\
\text { Cost }\end{array}$} & \multirow{2}{*}{$\begin{array}{l}\text { Probability of } \\
\text { Non- } \\
\text { compliance \& } \\
\text { Comments }\end{array}$} & \multirow{2}{*}{$\begin{array}{l}\text { Total } \\
\text { Score }\end{array}$} \\
\hline & & & & Positive & Negative & & & & \\
\hline $\begin{array}{c}\text { Phase } \\
\text { XII }\end{array}$ & $\begin{array}{l}\text { Finishing } \\
\text { Fresh Fruit } \\
\quad(2)\end{array}$ & $\begin{array}{l}\text { Sorted fruit } \\
\text { Energy } \\
\text { Packaging }\end{array}$ & $\begin{array}{l}\text { Finished } \\
\text { product }\end{array}$ & $\begin{array}{l}\text { Optimum } \\
\text { product }\end{array}$ & $\begin{array}{l}\text { Humans } \\
\text { Land }\end{array}$ & Labor & Solid waste & $\begin{array}{l}\text { Review } \\
\text { disposal, reuse, } \\
\text { and recycling } \\
\text { options }\end{array}$ & \\
\hline Grading & $\mathrm{N} / \mathrm{A}$ & 5 & 5 & + & 4 & 5 & 5 & 7 & 36 \\
\hline $\begin{array}{l}\text { Phase } \\
\text { XIII }\end{array}$ & $\begin{array}{l}\text { Squeezing } \\
\text { (1) }\end{array}$ & $\begin{array}{l}\text { Fruit } \\
\text { Energy }\end{array}$ & $\begin{array}{l}\text { Juices } \\
\text { Concentrates } \\
\text { Seeds } \\
\text { Peels } \\
\text { Rags }\end{array}$ & $\mathrm{N} / \mathrm{A}$ & Humans & Labor & $\begin{array}{l}\text { Seeds } \\
\text { Peels } \\
\text { Rags }\end{array}$ & $\begin{array}{l}\text { Reconsider } \\
\text { recovery of by- } \\
\text { products from } \\
\text { citrus waste } \\
\text { Review } \\
\text { disposal, reuse, } \\
\text { and recycling } \\
\text { options }\end{array}$ & \\
\hline Grading & N/A & 4 & 7 & + & 5 & 5 & 6 & 7 & 34 \\
\hline $\begin{array}{l}\text { Phase } \\
\text { XIV }\end{array}$ & $\begin{array}{l}\text { Finishing } \\
\text { Processed } \\
\text { Product } \\
\text { (1) }\end{array}$ & $\begin{array}{l}\text { Water } \\
\text { Bottles and } \\
\text { containers } \\
\text { Energy }\end{array}$ & $\begin{array}{l}\text { Packed } \\
\text { products } \\
\text { Byproducts } \\
\text { Wastewater } \\
\text { Vapors } \\
\text { Heat } \\
\end{array}$ & $\begin{array}{l}\begin{array}{l}\text { Optimum } \\
\text { product }\end{array} \\
\text { By products } \\
\text { production }\end{array}$ & $\begin{array}{l}\text { Humans } \\
\text { Water } \\
\text { Natural resources }\end{array}$ & Labor & $\begin{array}{l}\text { Solid waste } \\
\text { Bottles }\end{array}$ & $\begin{array}{l}\text { Review } \\
\text { disposal, reuse, } \\
\text { and recycling } \\
\text { options }\end{array}$ & \\
\hline Grading & N/A & 4 & 6 & + & 5 & 5 & 6 & 5 & 31 \\
\hline
\end{tabular}


Table 38. Environmental Gap Analysis and Ranking Scale of the Citrus Industry (Cont.)

(Adapted to the citrus industry from Science Applications International Corporation (SAIC), 1999 and Quinn, 1997).

\begin{tabular}{|c|c|c|c|c|c|c|c|c|c|}
\hline & \multirow[t]{2}{*}{ Operation } & \multirow[t]{2}{*}{ Inputs } & \multirow[t]{2}{*}{ Outputs } & \multicolumn{2}{|c|}{ Potential Impacts } & \multirow{2}{*}{$\begin{array}{c}\text { Cost of } \\
\text { Material } \\
\text { \& Toxic } \\
\text { Rating }\end{array}$} & \multirow{2}{*}{$\begin{array}{c}\text { Waste } \\
\text { Disposal } \\
\text { Cost }\end{array}$} & \multirow{2}{*}{$\begin{array}{l}\text { Probability of } \\
\text { Non- } \\
\text { compliance \& } \\
\text { Comments }\end{array}$} & \multirow{2}{*}{$\begin{array}{l}\text { Total } \\
\text { Score }\end{array}$} \\
\hline & & & & Positive & Negative & & & & \\
\hline $\begin{array}{c}\text { Phase } \\
\text { XV }\end{array}$ & $\begin{array}{l}\text { Marketing } \\
(1 \& 2)\end{array}$ & $\begin{array}{l}\text { Finished } \\
\text { product (1 \& } \\
\text { 2) } \\
\text { Packaging } \\
\text { Labels } \\
\text { Energy }\end{array}$ & $\begin{array}{l}\text { Marketable } \\
\text { product }\end{array}$ & $\begin{array}{l}\text { Optimum } \\
\text { product }\end{array}$ & $\begin{array}{l}\text { Humans } \\
\text { Land } \\
\text { Water }\end{array}$ & Labor & $\begin{array}{l}\text { Solid waste } \\
\text { Bottles } \\
\text { Cardboard }\end{array}$ & $\begin{array}{l}\text { Review } \\
\text { disposal, reuse, } \\
\text { and recycling } \\
\text { options }\end{array}$ & \\
\hline Grading & $\mathrm{N} / \mathrm{A}$ & 6 & $\overline{5}$ & + & 5 & 5 & 6 & 7 & 31 \\
\hline
\end{tabular}

1) Total score is given in terms of 1-to-10 grading system. Grading was based on negative risk level of pollutants impacting the environment:

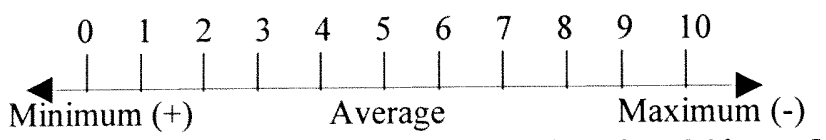

The author assigned grade values based on 36 hours ISO 14000 training given by SAIC, 1998.

2) $(1 \& 2)=$ Canning Plants \& Packinghouses

3) N/A: Not Action

4) Maximum grading points for a single activity (10) 


\subsubsection{Cost feasibility}

Defining costs associated with prevention-of-pollution opportunities is fundamental to implement programs. Application of new accounting methods that better allocate costs are to be used (Ellis, 1994).

A cost worksheet is presented, which is applicable to any citrus industry. Real data will quantitatively estimate implementation cost of a prevention-of-pollution program that offers saving opportunities. Cost feasibility in prevention-of-pollution preliminary assessments analyzes the implementation of prevention-of-pollution opportunities found in a preliminary assessment. The worksheet computes usual costs or capital facility, equipment, and operating expenses, hidden regulatory costs, and less tangible costs or future liabilities.

Table 39 provides a simplified worksheet for a prevention-of-pollution preliminary assessment. This table should serve for individual citrus industries according to their quantitative data. It is important to clarify that quantitative cost values should appear as positive values and quantitative saving values should appear as negative values. The difference, between the new costs before implementation of the prevention-ofpollution program and after implementation of the prevention-of-pollution program, should show the potential savings for the citrus industry. 


\section{Table 39. Prevention-of-pollution Cost Evaluation Worksheet for the Citrus Industry}

(Adapted from Dorsey, Raney, and Whitehead, 1994; Eisenhauer and Cranford, 1994; and Ellis, 1994).

\begin{tabular}{l|l|l|}
\hline \multicolumn{2}{|c|}{ Cost Item Implementation Cost (One Time, \$) } \\
\begin{tabular}{|l|l|l|}
\hline \multicolumn{2}{|c|}{ Total Cost Savings (\$) } & Refences \\
\hline $\begin{array}{l}\text { Engineering preliminary assessment } \\
\text { (Waste stream identification) }\end{array}$ & & \\
\hline Replacement of Equipment (If needed) & & \\
\hline Installation & & \\
\hline Start-up Training & & \\
\hline Administrative paper work & & \\
\hline Other & & \\
\hline Total Assessment Implementation Cost & & \\
\hline
\end{tabular}
\end{tabular}

\section{Incremental Operating Costs (Annual, \$/Year)}

\begin{tabular}{|l|l|l|}
\hline Change in raw materials consumption & & \\
\hline Change in maintenance requirements & & \\
\hline Change in operating activities & & \\
\hline Change in disposal cost & & \\
\hline Change in utilities cost & & \\
\hline Other & & \\
\hline Total Operating Cost & & \\
\hline
\end{tabular}

\begin{tabular}{|l|l|l|}
\hline \multicolumn{3}{|c|}{ Intangible Costs (Savings, \$/Year) } \\
\hline Penalties and fines & & \\
\hline Future Liabilities & & \\
\hline Total Intangible Cost & & \\
\hline
\end{tabular}

\begin{tabular}{|l|l|l|}
\hline $\begin{array}{l}\text { TOTAL ANNUAL COST (Savings, } \\
\text { \$/year) }=\text { Total Operating Cost }+ \text { Total } \\
\text { Intangible Cost }\end{array}$ & & \\
\hline $\begin{array}{l}\text { PAYBACK PERIOD (years) }= \\
\text { Implementation Cost / Total Annual }\end{array}$ & & \\
\hline$\underline{\text { Savings }}$ & & \\
\hline
\end{tabular}

NOTE: Reference column should contain the calculations or supporting documents used to arrive at the individual cost estimates. 
The previous sections of this study characterize and document contamination by the citrus industry of fresh fruit and processed product. This section offers options to minimize water, soil, air, and product contamination based on best available preventionof-pollution technologies.

\subsection{Agriculture, Harvesting, and Management Practices}

Even though agriculture and harvesting are not part of the processing operation, they contribute contamination at a multimedia level including to water, soil, air, and biota compartments. Technologies should be used to protect natural resources and prevent degradation of air, soil, and water quality. Some of these techniques are summarized in Table 40.

\subsection{Production Operations}

Waste prevention and reduction of waste volume generated during production operations are critical today. Water must be conserved to minimize costs incurred in the treatment and disposal of liquid waste. During processing of citrus, discharge of inedible portions of raw material is unavoidable. 


\section{Table 40. Technologies and Best Management Practices to Mitigate Contamination}

(Florida Department of Agriculture and Consumer Services, 1993 and Townsend, 1998).

\begin{tabular}{|c|c|}
\hline $\begin{array}{c}\text { Technology or } \\
\text { Management Practices }\end{array}$ & Description Reference \\
\hline Use of pesticides training & $\begin{array}{l}\text { A good pollution control opportunity for pesticides use should include } \\
\text { educational programs for growers to teach them the importance of } \\
\text { selecting pesticides with minimum adverse impacts. }\end{array}$ \\
\hline Biological pest control & $\begin{array}{l}\text { Use of natural biological cycles and controls as biological controls to } \\
\text { reduce pesticide use. This practice reduces the number of sprays } \\
\text { needed during citrus agriculture. }\end{array}$ \\
\hline Criteria to select chemicals & $\begin{array}{l}\text { Best management practices (BMPs) that use selective chemical } \\
\text { compounds to target specific insects instead of collective species, } \\
\text { which could destroy useful organisms in the grove. By using non- } \\
\text { selective pesticides or broad-spectrum pesticides, growers have to } \\
\text { spray more often to exterminate resistant insects. Resistant insects will } \\
\text { proliferate greatly since broad-spectrum pesticides kill natural } \\
\text { predators of pests. }\end{array}$ \\
\hline Integrated Pest Management & $\begin{array}{l}\text { Use of integrated pest management (IPM) to reduce application of } \\
\text { pesticides. For example, for fruit that is processed into juice, only one } \\
\text { or two sprays per year are required to prevent fungal diseases in trees. } \\
\text { In this case, insects and diseases that may cause fruit damages are not } \\
\text { important since cosmetic standards do not affect juice quality. For } \\
\text { fresh fruit, pest population has to be monitored very closely. Careful } \\
\text { pest control is critical because it determines the threshold of pesticides } \\
\text { use. In this case, it is recommended to use specific chemicals, } \\
\text { depending on type of target pest, instead of broad-spectrum pesticides, } \\
\text { which kill beneficial insects. }\end{array}$ \\
\hline Biotechnology Advances & $\begin{array}{l}\text { New disease-resistant hybrids to decrease pesticide applications by } \\
\text { using biotechnology research to produce disease-resistant varieties } \\
\text { should be done where possible. These varieties will require fewer } \\
\text { pesticide inputs than regular varieties, so pesticide releases to the } \\
\text { media will be considerably reduced. }\end{array}$ \\
\hline Cultural practices & $\begin{array}{l}\text { The improvement of cultural practices in the agriculture activity such } \\
\text { as conventional irrigation methods, application of broad-spectrum } \\
\text { pesticides, and land use to increase crop productivity and reduce the } \\
\text { incidence of pests and diseases on citrus crops. }\end{array}$ \\
\hline $\begin{array}{l}\text { Reduction of amounts of } \\
\text { chemicals used }\end{array}$ & $\begin{array}{l}\text { Better placement and reduced amounts of fertilizers by using under- } \\
\text { tree booms or throughout irrigation or micro-sprinklers to direct the } \\
\text { compound to the roots, not overhead or by flooding of the entire grove } \\
\text { as it is now done. Herbicides should be used under the tree to control } \\
\text { weeds that compete for water and fertilizers. }\end{array}$ \\
\hline
\end{tabular}




\section{Table 40. Technologies and Best Management Practices to Mitigate Contamination (Cont.)}

(Florida Department of Agriculture and Consumer Services, 1993 and Townsend, 1998).

\begin{tabular}{|l|l|}
\hline \multicolumn{1}{|c|}{$\begin{array}{c}\text { Technology or } \\
\text { Management Practices }\end{array}$} & \multicolumn{1}{|c|}{ Description Reference } \\
\hline Irrigation improvements & $\begin{array}{l}\text { Implementation of sprayers, that turn nozzles off and on depending on } \\
\text { tree size. This system can be implemented by using special sensors, } \\
\text { that, depending on the tree size, will maintain off or on the nozzle } \\
\text { spraying exact amounts of chemicals. This sensor is able to detect } \\
\text { small, large, and dead trees. For small trees only the lower nozzle } \\
\text { remains open, but for large trees all the nozzles are open. If any of the } \\
\text { trees die, the nozzle automatically is closed. This practice could save } \\
\text { around 30\% of spray material and consequently reduce in the same } \\
\text { amount chemical releases. }\end{array}$ \\
\hline $\begin{array}{l}\text { Precision agriculture } \\
\text { development }\end{array}$ & $\begin{array}{l}\text { The ultimate tool, which is being used in the citrus industry, is } \\
\text { precision agriculture development. Precision agriculture is a computer } \\
\text { project, Decision Information System for Citrus (DISC). DISC is a } \\
\text { computer tool that models citrus diseases localizing and processing } \\
\text { weather data to predict when disease conditions will be great to reach } \\
\text { the highest efficiency of each spray application. Knowing perfect time } \\
\text { for spraying will reduce chemical applications, therefore pesticide } \\
\text { releases into the environment. DISC also provides information } \\
\text { regarding type of soil in the agricultural area. Knowing soil } \\
\text { characteristics, the grower will control the application of fertilizers in } \\
\text { the area, reducing leaching of excess fertilizer into surface waters. } \\
\text { Therefore, where soils are low in organic matter, less herbicide can be } \\
\text { applied. }\end{array}$ \\
\hline $\begin{array}{l}\text { Florida citrus groves could become very friendly to the environment by balancing the needs of the } \\
\text { environment and the needs of } \\
\text { technology such as low volume computerized irrigation systems, spraying water and chemicals directly to } \\
\text { the root zone, and the most progressive management practices. }\end{array}$ \\
\hline
\end{tabular}


Citrus processing operations and packaging houses (fresh fruit) require the use of water that becomes wastewater and must be treated before discharge. By minimizing the quantity of water used during citrus process operations, the quantity of wastewater generated could be minimized. Another point is the cost of wastewater treatment due to its strength or organic load. Eliminating the use of water wherever practicable reduces significant waste loadings.

\subsubsection{Wastewater stream}

Water use in the citrus industry is classified in three categories: citrus processing, general cleaning, and personal use. A large volume of water is used in citrus industries on a daily basis (refer to Table 33). Prevention-of-pollution opportunities for effective water conservation programs are proposed. To avoid wastage in the citrus industry, a primarily survey is proposed to minimize unnecessary use of water (see Table 41).

\subsubsection{Solid waste stream}

Solid waste from the citrus industry is classified as non-food refuse and food residuals. Non-food refuse includes damaged cans, containers, packaging materials, broken pallets, and other similar inert materials. Food residuals includes all non-usable items of raw materials produced for processing damaged fruit, cull whole fruit, seeds, stems, leaves, peel, and other degradable materials. 
Table 41. Alternatives for Efficient Water Use.

\section{Category: Citrus processing}

Citrus processing (juice, concentrate, or fresh fruit) including raw product washing, rinsing, product conveying, vacuum condensing, heat processing (including preheating, pasteurization, and/or concentration) can cooling, product freezing, and miscellanea such as container washing and equipment lubrication.

\begin{tabular}{|l|l|}
\hline \multicolumn{1}{|c|}{ In Plant Activity } & \multicolumn{1}{|c|}{ Comments and Prevention-of-pollution Opportunities } \\
\hline Unattended Hoses & $\begin{array}{l}\text { Hoses, which are normally provided for equipment and general } \\
\text { plant cleanup, are frequently left unattended with water flowing } \\
\text { freely onto the floor. A good solution could be the } \\
\text { implementation of springloaded hose nozzles that automatically } \\
\text { shut down when released. Hoses are also used to lubricate } \\
\text { conveyors. Low volume spray heads will provide sufficient } \\
\text { water for belt lubrication. The water saved by implementing } \\
\text { these techniques readily justifies the cost of installation of these } \\
\text { sprays. }\end{array}$ \\
\hline $\begin{array}{l}\text { Tow water lines are recommended: one for equipment, which is } \\
\text { used intermittently during the operation, and another for idle } \\
\text { equipment; thus, it can be shut down when this equipment is not } \\
\text { needed. }\end{array}$ \\
\hline $\begin{array}{l}\text { Excessive overflows from } \\
\text { water recirculation systems }\end{array}$ & $\begin{array}{l}\text { Dump tanks, washers, and other recirculating water systems are } \\
\text { usually in continuous overflow. Flow rates should be adjusted to } \\
\text { minimum level required to accomplish the task. }\end{array}$ \\
\hline $\begin{array}{l}\text { Just by implementing these techniques and with educational prevention-of-pollution training to } \\
\text { employees, the industry can save between 30\% (American Water Works Association 1999) and } \\
\text { 32.6\% (Higgins 1995) of water use. }\end{array}$ \\
\hline \multicolumn{2}{|l}{ Category: General Cleaning } \\
\hline $\begin{array}{l}\text { General cleaning includes plant cleanup and waste conveying. It is observed that cleansing is a } \\
\text { function of the amount of energy imparted by the water on the raw product surface. Therefore, a } \\
\text { good physical arrangement (in banks for citrus) of spray nozzles and the type (fan-shaped nozzles } \\
\text { for citrus) will give high velocity and a greater cleansing efficiency with low water volume. }\end{array}$ \\
\hline
\end{tabular}


Table 41. Alternatives for Efficient Water Use (Cont.)

\begin{tabular}{|c|c|}
\hline In Plant Activity & Comments and Prevention-of-pollution Opportunities \\
\hline Roller type conveyor & $\begin{array}{l}\text { For the citrus industry a recommended conveyor is roller type. } \\
\text { This conveyor is effective and by revolving rollers turn the raw } \\
\text { product exposing all fruit surfaces to sprays. A suitable practice } \\
\text { to reduce water use during cleansing is to use recirculated water } \\
\text { for half of the nozzles placed at the beginning of the conveyor } \\
\text { and fresh water for the final set of nozzles placed at the end of } \\
\text { the conveyor. }\end{array}$ \\
\hline Minimization of waste loads & $\begin{array}{l}\text { Minimization of waste loads generated by cleanup operations } \\
\text { can be accomplished by following the recommended procedure: } \\
\text { 1. Dismantle or open all equipment as far as practical. } \\
\text { 2. Brush, sweep, and shovel all solid wastes into containers. } \\
\text { 3. Rinse equipment with low pressure cold water. } \\
\text { 4. Use squeegees or brushes, followed by high pressure, low } \\
\text { volume cold water, to clean floors. }\end{array}$ \\
\hline \multicolumn{2}{|r|}{ Category: Personal Use } \\
\hline \multicolumn{2}{|c|}{ Personal use includes water required by employees for personal and sanitary use. } \\
\hline In Plant Activity & Comments and Prevention-of-pollution Opportunities \\
\hline Housekeeping and training & $\begin{array}{l}\text { Implement housekeeping practices to wisely use water. These } \\
\text { practices include but are not limited to turn on the tap only when } \\
\text { necessary, repair leaky faucets, and install low-flow toilets. } \\
\text { Periodically offer plant-training programs to employees on water } \\
\text { reuse, recycling, importance of wise water use, impacts on misuse } \\
\text { of water, etc. }\end{array}$ \\
\hline
\end{tabular}


In-plant handling of citrus processing residuals may be handled or transported in containers such as bins or metal hoppers, by mechanical belts or pneumatic conveyors, or gutters. The greatest impact of citrus residuals in the case of juices and concentrates on the wastewater effluent occurs when these solid wastes are hydraulically handled as usually occurs in this industry. Elimination or minimization of these wastewater sources will contribute to the waste reduction program.

Solid waste properties depend on particle size, density, fluidity, and quantity. Based on these properties, the following are alternatives to handle solid waste material (see Table 42).

\subsubsection{Transportation and distribution}

Fresh citrus may be sensitive to chilling injury; therefore, it is important to store and transport them at the recommended temperature. Main injuries could be discoloration and failure to ripen properly. In order to minimize fruit decay and thus solid waste, fresh fruit has to be shipped and stored following these parameters (McGregor, 1987 and Florida Agriculture, 1999):

1) Previous treatment before transporting with wax, fungicides, or biphenyl-treated pads in packaging to limit the decay, and ethylene to avoid fruit de-coloration. 
Table 42. Alternatives to Handle Solid Waste.

\begin{tabular}{|l|l|}
\hline \multicolumn{1}{|c|}{ In Plant Activity } & \multicolumn{1}{|c|}{ Comments and Prevention-of-pollution Opportunities } \\
\hline Dry cleaning & $\begin{array}{l}\text { 1. Use vibrating screens or roller conveyors to remove } \\
\text { extraneous materials (e.g., leaves, foliage fragments) from } \\
\text { the fruit before washing. Handle these materials dry. } \\
\text { 2. Avoid washing fruit to remove dust and dirt adhering to the } \\
\text { fruit. Dust and dirt mixed with water increase concentration } \\
\text { of solids. Floating debris or leaves in wash tanks should be } \\
\text { skimmed from the water and deposited in containers, } \\
\text { avoiding these materials entering the system. }\end{array}$ \\
\begin{tabular}{|l} 
3ydraulic systems should be avoided if possible. If not, use \\
of reclaimed water instead of fresh should be considered.
\end{tabular} \\
\hline Collection of solid waste & $\begin{array}{l}\text { 1. } \begin{array}{l}\text { Size grading generates solid waste such as leaves, pits, } \\
\text { stems, crushed and undersized product, etc. These wastes } \\
\text { should be collected in containers to transport as dry waste. }\end{array} \\
\text { 2. Sorting or inspecting/picking is an operation that removes } \\
\text { culls and other unusable whole fruit units. These materials } \\
\text { should be handled dry. }\end{array}$ \\
\hline $\begin{array}{l}\text { Citrus waste handling after } \\
\text { citrus are processed }\end{array}$ & $\begin{array}{l}\text { Juice extracting and finishing equipment is used to produce } \\
\text { citrus juices and concentrates by mechanically compressing raw } \\
\text { products against screens or perforated plates. This waste is called } \\
\text { roughage and consists of stems, skin, seeds, fiber and other } \\
\text { coarse components of raw product. These residuals should be } \\
\text { transported on belt to process as byproducts. }\end{array}$ \\
\hline Recycling & $\begin{array}{l}\text { Plant cleaning is recommended to pick up solid waste on the } \\
\text { floor using vacuums, shovels, or others similar tools before } \\
\text { applying detergents and water. }\end{array}$ \\
\hline Plant cleaning & $\begin{array}{l}\text { Management of non-food residuals, such as citrus packaging, } \\
\text { pallets, bottles, and empty or damaged containers, should be } \\
\text { done by recycling methods classifying each material in different } \\
\text { barrels or bins to facilitate municipal solid waste collection or } \\
\text { any other recycling program in the facility location. }\end{array}$ \\
\hline
\end{tabular}


2) After fruit is packaged in the packinghouse, it has to be stored in a precooling room with temperature and relative humidity around $32-34^{\circ} \mathrm{F}$ and $85-90 \%$, respectively. Chilling injury below $31^{\circ} \mathrm{F}$ will be presented, thus solid waste generated.

3) Transit and storage life for Florida citrus oscillates between 4-8 weeks at these conditions mentioned above.

4) The most recommended citrus package is fiberboard box with a containing weight of 40,45 , and $86 \mathrm{lb}$.

5) Transportation more frequently used is refrigerated highway trailers.

6) Loading could be slipsheets, pallets, or hand-loaded.

\subsubsection{Use, reuse, and recycle}

Recovery of water from one operation to another is a good manufacturing practice (GPM) in the citrus industry. General sanitation practices have to be followed to comply with the FDA GMPs standards. The following water checklist will help the citrus industry to meet these standards (see Table 43).

Citrus packaging including empty bottles, boxes, bags, pallets, etc., constitutes approximately $30 \%$ of Municipal Solid Waste (MSW). One of the most useful tools to manage this type of waste is recycling operation. Not only the citrus industry but also 
consumers have to become more sensitive about this problem. Recycling recommendations follow:

1) Citrus processors should start to utilize a strategy of awareness or a thoughtful packager selection. This strategy should be more proactive instead of reactive. Implementation of recycling programs in the industry includes classification and collection of packaging waste by types. For example, plastic, carton boxes, damaged wood pallets, bags, etc. should be disposed in separate containers to facilitate final disposal.

2) Consumers should implement an in-house program to lower and facilitate packaging disposal. Household separation is divided into two types: commingled separation, which means that all recyclable materials are placed in a single container, and multibin separation, where each material goes into a separate container.

3) Educational training for administrative management, employees, and consumers should be encouraged to create environmentally sensitive human beings.

However, recycling can not be considered as the only solution to minimize packaging material. Recycling is just one tool to handle it at the end of the pipe. Source reduction from a packaging perspective is the key concept of minimal packaging. Develop ideal packages that meet functional requirements and minimize waste generation. 
Table 43. Water Economy Checklist for the Citrus Industry

(Adapted from USEPA, 1975).

\begin{tabular}{|c|c|c|c|}
\hline $\begin{array}{l}\text { Operation or } \\
\text { Equipment }\end{array}$ & $\begin{array}{c}\text { Recovery } \\
\text { Opportunity }\end{array}$ & $\begin{array}{c}\text { Reuse } \\
\text { Opportunity }^{2)}\end{array}$ & $\begin{array}{c}\text { Potential Opportunities for } \\
\text { Reused Water }\end{array}$ \\
\hline 1. Fruit dipping & Yes & No & Partial reused water plan in place \\
\hline $\begin{array}{l}\text { 2. Washing/Brushing of } \\
\text { fruit }\end{array}$ & Yes & $\mathrm{Yes}^{4)}$ & Need plan for water reuse \\
\hline 3. Rinsing fruit & Yes & $\mathrm{Yes}^{4)}$ & Partial reused water plan in place \\
\hline $\begin{array}{l}\text { 4. Fluming of unwashed } \\
\text { fruit }\end{array}$ & No & $\mathrm{Yes}^{4)}$ & Need plan for water reuse \\
\hline 5. Flumming of wastes & Yes & No & $\begin{array}{l}\text { Pretreatment of wastewater prior } \\
\text { to discharge }\end{array}$ \\
\hline $\begin{array}{l}\text { 6. Tank washers-original } \\
\text { water }\end{array}$ & Yes & No & $\begin{array}{l}\text { Pretreatment of wastewater prior } \\
\text { to discharge }\end{array}$ \\
\hline $\begin{array}{l}\text { 7. Spray or make-up } \\
\text { water }\end{array}$ & No & No & $\begin{array}{l}\text { Pretreatment of wastewater prior } \\
\text { to discharge }\end{array}$ \\
\hline $\begin{array}{l}\text { 8. Lubrication of } \\
\text { products in machines } \\
\text { (fruit size graders) }\end{array}$ & No & $\mathrm{Yes}^{4)}$ & Need plan for water reuse \\
\hline 9. Vacuum concentrators & Yes & $\mathrm{Yes}^{4)}$ & Partial reused water plan in place \\
\hline $\begin{array}{l}\text { 10. Washing empty } \\
\text { containers }\end{array}$ & No & No & $\begin{array}{l}\text { Pretreatment of wastewater prior } \\
\text { to discharge }\end{array}$ \\
\hline $\begin{array}{l}\text { 11. Washing containers } \\
\text { (juice bottles) after } \\
\text { closing }\end{array}$ & Yes & $\mathrm{Yes}^{4)}$ & Partial reused water plan in place \\
\hline 12. Bottled juice coolers & Yes & $\mathrm{Yes}^{4)}$ & $\begin{array}{l}\text { Water may be recirculated with } \\
\text { proper control (e.g., chlorination } \\
\text { and frequent cleaning) }\end{array}$ \\
\hline 13. Evaporator water & Yes & $\mathrm{Yes}^{4)}$ & Partial reused water plan in place \\
\hline 14. Plant cleanup & No & No & $\begin{array}{l}\text { This water is not recommended to } \\
\text { be reused. However, dry cleaning } \\
\text { is recommended (sweeping } \\
\text { before hosing). }\end{array}$ \\
\hline
\end{tabular}

1) Means that current water reuse programs are being applied in the citrus industry

2) Opportunity of wastewater to be reused either within the system from which it was recovered (e.g., recirculated) or in some other operation.

3) Suggested water recovery during citrus operation activities. Water recovered may be used to fill container coolers.

4) Water may be reused for make-up water in preceding operations. However, water quality must be observed. 
Traditional citrus products packaging tends to motivate consumers to buy more products than minimization of amount of packaging waste. From an environmental perspective, the idea could be educating consumers about package waste volume versus consumer convenience. The consumer always goes for their convenience; thus, citrus product producers hit that target to increase sales.

However, more environmental campaigns could be spread to convince consumers that a beautiful package does not imply better product quality. An environmentally friendly package could fulfill the same purposes but produce less package volume, therefore less waste generation. Biodegradable packaging could be a choice for citrus packaging products. These packages could be disposed or taken to biological processes such as a composting operation. The idea of composting is to promote this operation while developing markets to sell the compost. If industry could reach that goal, composting could become a municipal solid waste solution.

Since the citrus industry has had rapid growth, considerable waste disposal problems have occurred. Citrus refuse is $45 \%$ of whole fruit consisting of peel, rag, seeds, and juice sacs. Some recovery products that can be produced from citrus waste at an industrial level to minimize citrus waste are essential oils, dried citrus pulp, citrus molasses, products from citrus seeds, bioflavonoids, pectic substances, washed pulp concentrates and dried juice sacs, peel products, fermentation products, animal feed, cleaners, enzymes, pharmaceutical products, etc. The citrus industry has a good opportunity to recover 
maximum waste generated during operations and transform them into byproducts. The waste loop could close, and a new environmental industry could emerge.

\subsubsection{Waste management}

A total waste management concept must include coordinated efforts between those responsible for raw product, production management, plant cleaning, and maintenance. The following are the prevention-of-pollution opportunities proposed for the citrus industry to develop a successful waste management program.

\subsubsection{Management considerations}

The following are important actions that must be pursued by management in order to improve environmental standards:

1) Development of a processing plan that optimizes the utilization of raw material in both processing plants and packing houses. This plan should consider the options presented above.

2) Appointment and delegation of authority to appropriately qualified "waste management personnel."

3) Educational programs that train employees and makes them aware of preventionof-pollution and waste management. Possible use of incentives to encourage adoption of waste reduction practices. 
4) Appropriate maintenance and use of records including quantity, quality, and raw product characteristics, water volume used by process activity, total and area waste volume, process downtimes and causes including equipment failure, personnel negligence, etc.

5) Waste load effluents, such as BOD, SS, COD, can be reduced by implementing better housekeeping activities before, during, and after in-plant production, e.g., install racks (different distance separation between bars) on sinks to stop and collect solid particles and/or oil residuals (if applicable) before they reach the wastewater stream. The industry should perform dry cleaning as much as possible instead of using water to move solid wastes.

6) Data regarding disposal requirements according to the localization of the facility.

\subsubsection{Raw fruit considerations}

1) Development of a program that plans and manages fruit season schedules and agricultural practices, best management practices, technology, and regulations to reduce process wastes. This schedule could include varieties for utilization values (depends on final market of fruit: fresh fruit or processed fruit), disease and insect resistance, maturation level, size, shape, and suitable quality for manual or mechanical harvesting. Replace, when possible, pesticides with high risk of contamination in both ecosystem and fruit for less hazardous substances available on the market. 
2) Growers should harvest the fruit at optimum maturity, with post- utilization to minimize waste volume.

3) Synchronize harvesting, transporting, and processing operations to avoid delays that result in raw quality deterioration, lower utilization, and increased waste volume.

4) Be selective while managing harvesting practices to obtain cleaner fruits with minimum bruising. If possible, negotiate with growers culling or sorting of fruit in the grove to eliminate delivery of unacceptable fruit to the processing facility.

5) Selection and management of handling systems that are economical and convenient, minimizing fruit bruising.

6) Selection and management of transportation systems to minimize losses in quality, thus increasing waste volume.

7) Check environmental factors closely to control variables after harvesting including temperature, relative humidity, chemical post-treatment, storage conditions, etc.

\subsubsection{Processed fruit needs}

1) Balance process rate and equipment capacities to prevent bottlenecks, overflows, and equipment failure that interrupts the process line causing product or quality losses. Antiquated equipment such as holding tanks, washers, pasteurizers, conveyors, fillers, closers frequently cause these problems. 
2) Good selection of processing methods and equipment systems to optimize production and reduce waste. In the case of product cleaning and handling systems for citrus, dry cleaning systems are recommended such as roller conveyors. High-pressure low volume water sprays are recommended for cleaning. The extraction equipment should be effective to get an efficient recovery of wastes produced after squeezing fruit. Appropriate automatic process equipment controls to control heating and flow regulating pumps during pasteurization and concentration of citrus juices should be installed to meter controls to wisely use natural resources (energy and water). Automatic shut-off valves at all water outlets, automatic level regulators in washer tanks, etc., should be also installed to use water only when necessary, minimizing misuse. Preventive equipment maintenance practices to reduce operational breakdowns and therefore generation of waste.

\subsubsection{Cleanup considerations}

Separation of solids and liquid wastes: Continuous solid waste collection and classification according to reuse waste potential. Avoid using water as the transport medium option. Implement a dry cleaning plan for cleanup. Do not use water hoses to move solid waste. Use dry clean tools such as vacuums, compressed air streams, floor brooms, scoops, etc. Use high-pressure low volume water during cleanup, reducing water volume wasted. 


\section{CONCLUSIONS}

This study specifically completed a general inventory on the citrus industry, which includes agricultural activities, fresh fruit, and processed fruit processes. Available data were used as examples of quantities generated by citrus production during seasons, amount of water used for each process, amount of solid waste and wastewater generated on each process. This study also considered the step-by-step path that citrus fruit follows since the seed is planted until a consumer gets the final product named fresh fruit, concentrate pulp, juices, oils, essences, etc. It also characterized contamination in soil, water, air, and fruit as a multimedia problem.

This study assessed and identified prevention-of-pollution opportunities, characterizing adverse environmental impacts. Knowing these adverse impacts, options are proposed to help citrus growers to comply with environmental regulations but also to sustain a growing profitable agricultural industry in Florida. A good example of this is the development and dissemination of Best Management Practices. Environmental management has traditionally focused on pollution control strategies for keeping pollution from reaching the environment. At this time, prevention-of-pollution opportunities have changed environmental protection. Prevention-of-pollution is a more powerful and economical strategy. The target now is to identify the process that causes pollution and to implement prevention-of-pollution in the first place. 
Through this study, all waste streams were considered, whether or not they were regulated or required an environmental permit. After identifying these waste streams, the study not only considered the waste that the processing industry generates but also wastes created before fruit comes to the facility to be transformed and after consumers get final product either fresh fruit or processed fruit such as juice or concentrates. Water conservation and methods for reducing or recycling the waste stream were also considered.

Prevention-of-pollution for the citrus industry promotes the concept of green engineering, by proposing waste reduction opportunities and alternatives to wisely use natural resources, increasing reuse of waste generated during the citrus process. That concept maintains a good management plan in both recycling and waste stream reductions before end of pipe and can be implemented without lowering product quality or integrity. Therefore, a green citrus product, fresh fruits or processed, can be environmentally compatible and commercially viable.

A preliminary assessment of the citrus industry is compiled and discussed showing that pollution levels in the citrus industry can be minimized. For example, croppers can adopt proper control measures during application of chemicals to reach minimum plant required nutrients and pesticides instead of over-application of these chemicals. Reducing the number of applications and increasing the period between treatment and harvest will 
result in lower residual value. Effective chemical application reduces the pollutant loads into environmental compartments. Other considerations include the following:

- A careful evaluation of the environmental benefits and adverse impacts of the citrus industry since seed is planted until consumers get final products.

$\square$ Conservation of water.

- A proactive plan to reduce waste generation by improving industrial processes, planned transportation and distribution, storage, and recycling.

- Transfer of environmental knowledge to effectively apply to the citrus industry.

- Encourage employees training to become an environmentally educated society.

a Development of prevention-of-pollution opportunities that could be applied to the citrus industry that are cost effective and represent in the near future good revenues to the industry.

In the case of the citrus industry, selected for this study, it would appear that contaminant characterization and monitoring technologies should have the greatest market opportunity in the near future. This conclusion is driven by the fact that the citrus industry is just now beginning the process of identifying their prevention-of-pollution opportunities. As these opportunities mature, the industry fill its needs, thus more sophisticated and environmentally safe products will emerge. Comparing USA, Japan and Germany, it can be concluded that Japan and Germany are more developed in the area of 
environmental laws and expertise. These markets show the greatest potential opportunity for waste minimization regarding reuse and recycling.

The study completed an effort to comprehensively document the citrus industry, identifying options for prevention-of-pollution while ensuring product quality for consumers. The study invokes the "Eco-product Design Approach" as a basis for recommending better agricultural practices incorporating both environmental and human health values.

Florida is the largest citrus producer in the USA; therefore, more research about waste characterization could be done to generate marketable byproducts that offer more environmentally safe choices to the pharmaceutical and the food industries, environmentally safe. These products include cleaners, enzymes, oils, animal feeds, essences, etc. 
A recommended method to assess prevention-of-pollution programs in the citrus industry or any other industry could include

- Planning and organization

- Waste streams characterization

- Establishing the most useful strategy prioritizing streams

a Identifying prevention-of-pollution opportunities

a Analyzing proposed alternatives, including cost and environmental benefits

a Final results for implementation and continuous evaluation.

\section{LIMITATIONS OF THIS STUDY}

- Actual assessment of facilities such as access to conduct detail assessment is limited and difficult at times.

a Quality of data available in documents including the Internet is difficult to judge since it is very general in content.

a Data collected is reported on long periods of time (e.g., year to year).

a Further research: It will be interesting to take information and verify with specific facilities and conduct an assessment more specifically. 


\section{REFERENCES}

ANSI, American National Standard Institute (1997) Environmental Auditing Standards and Guidelines, http://www.ansi.org/public/iso 14000/subject/audit.html, November 8, 1999.

ANSI, American National Standard Institute (1999) Environmental Auditing Standards and Guidelines, http://www.ansi.org/public/iso14000/subject/audit.html, March 17, 2000.

AWWA, American Water Use Association (1999) Be Water Wise, http://www.waterdata.com, December 10.

Alan, C. Y. (1985) Insecticide and Acaricide Test, V. 10, College Park, Md.: Entomological Society of America.

Allenby, B. R., and Fullerton, A. (1992) Design for Environment - A new Strategy for Environmental Management, Pollution Prevention Review, Winter 1991-1992, pp. 51-61.

Becker, W. J., and Johnson, F. A. (1992) Agricultural Pesticide Safety, Institute of Food and Agricultural Science, IFAS, Circular Number 779.

Berk, Z. (1969) Industrial Processing of Citrus Fruit, United Nations Industrial Development Organization, Vienna, Food Industry Studies, Number 2, United Nations, New York.

Blumenfeld, K., Earle III, R., and Shopley, J. (1997), Identifying Strategic Environmental Opportunities: A Life Cycle Approach, Food Technology Journal, Michigan, V. 24, pp. 45-57.

Brown, R. B., Horncby, A. G., and Hurt, G. W. (1991) Soil Ratings for Selecting Pesticides for Water Quality Goals, Institute of Food and Agricultural Science, IFAS, Circular 959.

Capaccio Environmental Engineering (1999) ISO 14000, http://www.capaccio.com/ July 5, pp. 4-16.

CFR, Code of Federal Regulations (1999) Title 40, Subpart C, 470.32, Citrus Products Subcategory, http://www.access.gpo.gov/nara/cfr/cfr-table-search.html, December 9, 1999.

Ciba-Geigy (1975) Citrus, Ciba-Geigy Agrochemicals, Technical Monograph 4.

Citrosol Company (1998) Technical Brochure, pp. 10 pages. 
Citrus Summary (1996-1997) State Statistical Report, http://www.nass.usda.gov/f1/citrus/cs96/ 96cs3235.htm, pp. 43-48, July 22, 1999.

Citrus Web Site (1999) The Story of Florida Orange Juice http://www.users.aol.com/chettown/ citrus.htm, July 12, pp.1-5.

Citrus Quality (1998) Cleaning, http://www.globalcitrusresources.com Fruit Packinghouses, Global Citrus resources, January 2, 1999, 2 pages.

Committee on Analysis of Research Directions and Needs in U. S. Manufacturing, (1991) The Competitive Edge: Research Priorities for U. S. Manufacturing, National Academy Press, Washington, D.C., pp. 235- 242.

Committee on Engineering Design Theory and Methodology (1991) Improving Engineering Design: Designing for Competitive Advantage, National Academy Press, Washington, D.C., pp. 431-445.

Crosby, D. G. (1965) Research in Pesticides, The Intentional Removal of Pesticide Residues, Academic Press, New York, NY, pp. 213-223.

DERM, Dade County Environmental Resources Management (1997), Inspection Reports.

Danovan Brown \& Associates - DBA (1999) Fresh Fruit, http://www.globalcitrusresources. com/fruitjuices.html, May 12.

Davison Ben David, M. (1975) Mineral Nutrition and Irrigation in Citrus Crops CibaGeigy Agrochemicals, Technical Monograph 4.

Del Bottcher (1984) How Agriculture Affects Aquatic Systems, Best Management Practices, Institute of Food and Agricultural Science, IFAS, Technical Report SP 25.

Department of Agriculture and Consumer Services, DACS (1992) Florida Pesticide Laws and Rules, Chapter 487 -- Florida Statutes.

Dole Food Company, Inc., (1999) Citrus, http://www.dole5aday.com/ABAUT/CITRUS/ citrus harvested, March 17, pp. 9 pages.

Dorsey, J. A., Raney, E. A., and Whitehead, J. K. (1994) A Tool for Designing Pollution Prevention into U.S. Department of Energy Facilities, Air and Waste Management Association Annual Meeting, Design for Environment Session, June, Cincinnati, OH.

DuPont De Nemours and Co. (1983) Florida Citrus Herbicides Technical Manual, Biochemical department, Wilmington, DE. 
DuPont De Nemours and Co. (1983) Florida Citrus Weed Identification Guide, Biochemical department, Wilmington, DE.

Dupuis, G. (1975) Pesticide Residues in Citrus Ciba-Geigy Agrochemicals, Technical Monograph N.4, pp. 81-88.

Eisenhauer, J., and Cranford, B. (1994) Setting Priorities for Pollution Prevention, Denver,CO.

Environmental Quality and Efficiencies (1998) Emerging Opportunities, http://www.igc.apc.org/eco-ops/gfa/eqe core.html, May 12, 5 pages.

Ellis, M.D. (1994) The Role of Engineering in Sustainable Development, American Association of Engineering Societies, Washington, D.C.

Eyring, G. (1994) How Environmental Policy can Encourage Green Products Design, Pollution Prevention Review, winter 1994-1993, pp. 81-92.

Fasulo, T. R., and Knapp, J. L. (1995) Insects Institute of Food and Agricultural Sciences, IFAS, University of Florida, Gainesville, Section V1- V16.

FDC, Federal Food, Drug and Cosmetic Act (1987) Food Tolerances Listed in the CFR Section 408, 409.

Florida Agriculture (1999) Approaches to Processed and Fresh Fruit Management, http://www.hammock.ifas.ufl.edu May 30, 2 pages.

Florida Agricultural Statistics Service (1998) Florida Citrus Production, Annual Report, Season 1997-1998, pp. 10 pages.

Florida Citrus Mutual (1999) Citrus Industry Highlights, http://www.fl-citrus-mutual.com, December 7, 1999.

Florida Department of Agriculture and Consumer Services (1993). Florida Agriculture Citrus Facts, Bureau of Information Services.

Florida Department of Agriculture and Consumer Services (1994) Florida Agriculture Facts, Bureau of Information Services.

Florida Department of Citrus (1999) Economic and Market Reseacrh, http://www.fred.ifas.ufl.edu/citrus/, March 21, 2000. 
Florida Department of Citrus Management (1996) Agricultural Chemicals on Ridge Citrus, Florida Citrus Pest Management Guide.

Florida, State Statistical Report (1999) Citrus Summary, http://www.nass.usda.gov/fl/citrus /cs96/96cs 5 7.htm, Principal Citrus Fruits, pp. 6 pages, August 31.

Florida Agricultural Statistic Service (1999) Citrus Summary State Statistical Report (1996-1997), http://www.nass.usda.gov/fl/citrus/cs96/ 96cntent.htm, pp. 40-41, August 31.

Food Quality Protection Act (1996), pp. 37-45.

Ford, H. W., Bishop, C. B., and Carlisle, V. W. (1985) A Guide for Plastic Tile Drainage in Florida Citrus Grove, Institute of Food and Agricultural Sciences, IFAS, Circular 661.

Foulke, J. (1991) Food and Drug Administration, FDA, Reports on Pesticides in Foods.

Global Green Standards (1998) Developing Ideas ISO 14000 http://iisd1.iisd.ca/greenstand/ default.htm, June 22, pp. 1-9 pages.

Grierson, W., Miller, W. M., and Wardowski, W. F. (1985) Packing Guide Machinery for Florida Citrus Packinghouses, Institute of Food and Agricultural Sciences, IFAS, Bulletin 803.

Harmon, M. (1994) First There Was ISO 9000, Now There's ISO 14000, Quality Digest, July, pp. 24-31.

Hemenway, C. G. (1995) 10 Things You Should Know About ISO 14000, Quality Digest, October, pp. 49-51.

Helling, C. S., and Turner, B. C. (1968) Pesticide Mobility Science, vol. 162, pp. 562563.

Higgins, T. E. (1995) Pollution Prevention Handbook, Lewis Publisher, Boca Raton, pp. 418-423.

Hornsby, A. G., and Augustijn-Beckers, P. W. M. (1991) Managing Pesticides for Crop Production and Water Quality Protection, Pest Control Guides, Institute of Food and Agricultural Sciences, IFAS.

Hume, H. H. (1999) The Cultivation of Citrus Fruit, New York: The Macmillan Co., 1926 - data for 1997-98. 
Institute of Food and Agricultural Sciences, IFAS, (1985) Weeds of the Southern United States, Florida Cooperative Extension Service, University of Florida, Gainesville.

ISO 14000 (1998) ISO 14000 Standards for Environmental Management, http://www.iso14000.com July 5, 5 pages.

Kader, A. A., Kasmire, R. F., Gordon, F. M., Reid, M. S., Sommer, N. F., and Thompson, J. F. (1985) Postharvest Technology of Horticultural Crops, Cooperative Extension University of California, Special Publication 3311.

Katsuyama, A. M. (1979) A Guide for Waste Management in the Food Processing Industry, The Food Processors Association, Washington, D.C.

Kenaga, E. E., and Goring, C. A. (1980) Relationship between Water Solubility, Soil Sorption, Octanol Water Partitioning, and Concentration of Chemicals in Biota, Special Technical Publication 707, American Society for Testing and Materials.

Kesterson, J. W., and Braddock, R. J. (1975) Citrus Fruit Processing, Technical Publication, Number 4. Citrus, Ciba-Geigy Agrochemicals.

Kinsella, J. (1994) ISO 14000 Standards for Environmental Management, Armonization del Comercio, International y Medio Ambiente, Buenos Aires, Argentina, September 7-9, pp. 3p.

Knapp, J. L. (1996) Fungal Diseases Institute of Food and Agricultural Sciences, IFAS, University of Florida, Gainesville, Section VI1- VI14.

Labanaudkas, C.K., Jones, W. W., and Embleton, T. W. (1969) Low Residue Micronutrient Nutritional Sprays for Citrus First International Symposium, University of California Press, Riverside, California, pp. 1755-1757.

Langham, M. R., and McGrail, L. (1987) Economic and Environmental Aspects of Aerial and Ground Applications of Pesticides in Florida Agriculture, Institute of Food and Agricultural Sciences, IFAS, Bulletin Number 868.

Lehman, H., and Pimentel, D. (1993) The Pesticide Question, Chapman \& Hall, New York, NY., pp. 175-182.

Linker, H. M., and Anderson, J. R., Jr. (1988) Reduction of Pollutants from Irrigated Farming, North Carolina, Project Number 87-607. 
Long, S. K. (1993) Citric Acid from Citrus Processing Wastes, Federal Department of Environmental Pollution, Waste Management Pollution Prevention Program, Library Number 2000-014.

McGregor, B. M. (1987) Tropical Products Transport Handbook, Unite States, Department of Agriculture, Office of Transportation, Handbook Number 668.

Metcalf, R. L. (1955) Organic Insecticides, Their Chemistry and Mode of Action Interscience Publishers, New York, NY.

Minessy, F. A., El-Azab, E. M., and Abdel, R. (1973) Effect of Fungal Infection on the Nutritional Status of Sour Orange and Cleopatra Mandarin Seedling, The Second International Citrus Congress, Spain, pp.91-92.

Motavalli, J. (1997) The Producer Pays, http://www.emagazine.com/0597feat2.html, Extracted from The Environmental Magazine, May-June 1997, 7 pages.

Nadakavukaren, A. (1995) Our Global Environment a Health Perspective, Waveland Press, Inc. IL, pp. 333-337.

National Canners Association (1974) Liquid Wastes from Processing Fruits, Vegetables and Specialties D-2756, Berkeley, CA.

National Agricultural Statistics Services (1999) State Statistical Report, http://www.nass.usda.gov/fl/citrus/cs96/96cs3235.htm, November 2, 1999.

National Research Council, NRC (1987) Regulating Pesticides in Food: The Delaney Paradox, National Research Council, National Academy Press, Washington, D. C., pp. 21, 59-63, 68,69,85,146.

Nesheim, O. N. (1993) Best Management Practices to Protect Ground Water from Agricultural Pesticides, University of Florida, Technical Report RF-WQ108.

Ney, R. E. (1995) Fate and Transport of Organic Chemicals in the Environment Government Institute, Inc., Rockville, Maryland, pp. 9-24.

Ney, R. E. (1981) Fate, Transport, and Prediction Model Application to Environmental Pollutants, Spring Research Symposium, James Madison University, Harrisonburg, Virginia.

Pratt, J. J. (1970) The Problem of Pesticide \& Animal Matter as Non-intentional Additives, Food Technology College, Food Technology Journal, Michigan, V. 24, pp. 59-64. 
Quinn, Barbara (1997) Creating a New Generation of Environmental Management, Pollution Engineering, June 1997, pp. 60-62.

Rao, P. S. C., and Hornsby, A. G. (1991) Behavior of Pesticides in Soil and Water, Institute of Food and Agricultural Sciences, IFAS, Soil Science Fact Sheet SL 40.

Reynolds, S. P. (1997) The Germany Recycling Experiment and its Lessons for the United States, http://www.law.vill.edu/vls/journals/elj/volume6 1/reynolds.htm June 25, 27 pages.

Science Applications International Corporation (SAIC) (1999) Environmental Management Systems, ISO 14001 EMS Training Course, Hemispheric Center for Environmental Technology (HCET).

Sheffield, C. W., and Sims, M. D. (1984) Spray Irrigation of Citrus Waste, Federal Department of Environmental Pollution, Waste Management Prevention Program Library Number 200-013.

Smilanick, J. L. (1997) Improved Control of Green Mold of Citrus with Imazalil in Warm Water Compared with its Use in Wax, Plant Disease, Vol 81, No. 11, November 1997, pp. 1299-1304.

Society of Environmental Toxicology and Chemistry (SETAC), Web Site (1998) Life Cycle Tools, Management, and Product Policy, http:/www.ec.gc.ca/ecocycle/issues, February 18, pp.1-10.

The Florida Department of Citrus (1999) http://www.floridajuice.com/floridacitrus/intro.html, September 3.

The Ultimate Citrus Page (1999) Florida Citrus and the Environment, http://www.members.aol.com/chettown/citrus/environment.html, The Environment, pp. 4 pages, January 13, 1999.

Thomann, R. V., and Mueller, J. A.(1994) Principles of Surface Water Quality Modeling and Control, Harper Collins Publishers, pp. 385-390.

Townsend, C., (1998) Technology of Sustainable Agriculture, Forum, Florida Gulf Coast University, April 7, 1998.

Townsend, C., (1999) The Ultimate Citrus Page http://www.users.aol.com/chettown/ December 15, 1999, 5 pages. 
Tibor, T., and Feldman, I. (1996) ISO 14000: A Guide to the New Environmental Management Standards, Irwin Professional Publishing, Chicago, IL, USA.

Truhant, D. W. (1977) Chemistry and Ecotoxicology of Pollution Chapman \& Hall, New York, NY., pp. 75-83

Tucker, D. P. H. (1995) Citrus Irrigation Management, Institute of Food and Agricultural Sciences, IFAS, Circular 444.

Tucker, D. P. H., and Singh, M. (1990) Florida Citrus Weed Management, Institute of Food and Agricultural Sciences (IFAS), Section XII.

University of Florida (1995) ENY-601 Summary Report, 12 p.

U.S. Code 1993, Title 42, Section 13041 et seq., Pollution Prevention Act of 1990.

USDA (1998a) Citrus 1997-1998 Summary, http://www.nass.usda.gov/f1/citrus/cit92398.htm, August 31, 1999.

USDA (1998b) Forecasting Florida Citrus Production, http://www.nass.usda.gov/f1/citrus/ 9798broc.htm, August 31, 1999.

USDA (1998c) Seasons Highlights, http://www.nass.usda.gov/fl/citrus/cs95/95cs 1 4.htm, August 31, 1999.

USDA (1999) Florida Citrus Statistics, http://www.nass.usda.gov/fl/citrus/ 9798broc.htm, September 19, 1999.

USEPA (1996) Governor's Awards for Outstanding Achievement in Pollution Prevention Ohio's, Tenth Annual Cincinnati, $\mathrm{OH}$.

USEPA (1990) Nonoccupational Pesticide Exposure Study (NOPES), EPA/600/390/003, January.

USEPA (1993) Pesticides Potentially Affected by the Court of Appeals Ruling, Washington, D.C.

USEPA (1992a) Facility Pollution Prevention Guide, Center of Environmental Research, Technical Report 600/R-92/088, Cincinnati, Ohio, pp. 65-68, 128-129.

USEPA (1992b) Pollution Prevention Fact Sheet, Office of Pollution Prevention and Toxics, Washington. Library Number 0100-001. 
USEPA (1992c) Terms of Environment Glossary, Abbreviations, and Acronyms, EPA 175-B-92-001, pp. 31.

USEPA (1991) Unraveling Delaney's Paradox, Institute for Science and Society, Washington, D.C.

USEPA (1975) Pollution Abatement in the Fruit and Vegetable Industry - In Plant Control of Processing Wastewater, Washington, D.C., Volume 3, pp. 14-22.

USEPA (1974) Wastewater Characterization for the Specialty Food Industry, EPA660/2-74-075, Corvallis, OR.

USEPA (1978) Overview of the Fresh Pack Food Industry, EPA-600/2-78-276, Cincinnati, $\mathrm{OH}$.

USEPA (1997) Battling the Medfly, Prevention, Pesticides and Toxic Substances, http://www.doacs.state.fl.us/medfly.epa.html, October 28, 1999, pp. 1-5.

Vergano, P. J. (1991) Food Packaging - An Environmental and Regulatory Issue, Food Industry Environmental Conference, Clemson University, Atlanta GA, Nov. 11-13, pp.129-140.

Wanielista, M. P., Yousef, Y. A., Taylor, J. S., and Cooper, C. D. (1984) Engineering and the Environment, Broks/Cole Engineering Division, California, pp. 11-17, 114-115.

Westlake, W. E., and Gunther, F. A. (1965) Occurrences and Mode of Introduction of Pesticides in the Environment, American Chemical Society, Washington, D.C. In Gould, R. F., Advances in Chemistry Series 60, pp. 110-121.

Winter, C. K. (1993) Pesticide Residues and the Delaney Clause, Food Technology College, FTC, Michigan, V. 49, pp. 81-86.

Winter, C. K. (1992a) Dietary Pesticide Risk Assessment, Environmental Contamination Toxicology Journal, V. 23, pp. 23-67.

Winter, C. K. (1992b) Pesticide Tolerances and their Relevance as Safety Standards, Regulations of Toxicology and Pharmacology, V. 15, pp. 137-150.

Wills, R. B. H., Lee, T. H., Graham, D., McGlasson, W.B., and Hall, E. G. (1981) Postharvest AVI, pp. 102-108. 
APPENDIX 1 - Permission to Use Citrus Photographs 


\section{Subject: Re: Citrus Photograps}

Date: Thu, 17 Dec 1998 10:22:15 -0500

From: Chet Townsend <chet@ultimatecitrus.com>

To: $\quad$ "Carmen Aponte" < caponte@eng.fiu.edu>

At 10:06 AM 12/17/98 -0500, you wrote:

$>$ Hello, my name is Carmen Alicia Aponte, I student at Florida International University $>$ (FIU), College of Engineering and Design, MS Environmental Engineering. I am $>$ working on my graduation thesis "Pollution Prevention of the Citrus Industry." I $>$ would like to request a permission to use some of your photographs published in the $>$ citrus home page. Could you please let me know what is the procedure to use them?

$>$ Thanks a lot for your cooperation.

$>$

$>$ Carmen Alicia Aponte

\section{Hi Carmen:}

You have permission to use any of my pictures as long as you give proper credit: "Copywrite by Chet Townsend".

Regards,

Chet Townsend

Drink More Orange Juice, Eat More

Grapefruit and Keep Our World Healthy and Strong!

Chet Townsend -- LaBelle, Florida

chet@ultimatecitrus.com

http://www.ultimatecitrus.com 